\title{
The Margins Of Myddle: Poverty And Community In A Shropshire Parish, C. $1601-1800$
}

\author{
Betsy L. Morgan-Cutright
}

Follow this and additional works at: https://researchrepository.wvu.edu/etd

\section{Recommended Citation}

Morgan-Cutright, Betsy L., "The Margins Of Myddle: Poverty And Community In A Shropshire Parish, C. 1601-1800" (2018). Graduate Theses, Dissertations, and Problem Reports. 7218.

https://researchrepository.wvu.edu/etd/7218

This Dissertation is protected by copyright and/or related rights. It has been brought to you by the The Research Repository @ WVU with permission from the rights-holder(s). You are free to use this Dissertation in any way that is permitted by the copyright and related rights legislation that applies to your use. For other uses you must obtain permission from the rights-holder(s) directly, unless additional rights are indicated by a Creative Commons license in the record and/ or on the work itself. This Dissertation has been accepted for inclusion in WVU Graduate Theses, Dissertations, and Problem Reports collection by an authorized administrator of The Research Repository @ WVU.

For more information, please contact researchrepository@mail.wvu.edu. 


\title{
THE MARGINS OF MYDDLE: POVERTY AND COMMUNITY IN A SHROPSHIRE PARISH, C. 1601-1800
}

\author{
Betsy L. Morgan-Cutright \\ Dissertation submitted to the Eberly College of Arts and Sciences \\ at West Virginia University \\ in partial fulfillment of the requirements \\ for the degree of
}

Doctor of Philosophy

in

History

Kate Kelsey Staples, Ph.D., Committee Chairperson

Katherine Aaslestad, Ph.D.

Joseph Hodge, Ph.D.

Susannah Ottaway, Ph.D.

Matthew Vester, Ph.D.

Department of History

\section{Morgantown, West Virginia}

2018

Keywords: Myddle, Shropshire, The History of Myddle, Richard Gough, community, belonging, poverty, gender, Old Poor Law, Elizabethan Poor Law, poor law administration, settlement laws, illegitimacy, pauper apprenticeship

Copyright 2018 Betsy L. Morgan-Cutright 


\section{ABSTRACT \\ The Margins of Myddle: Poverty and Community in a Shropshire Parish, c. 1601-1800 Betsy L. Morgan-Cutright}

A local and microhistorical analysis of poverty in the unusually well-documented Shropshire parish of Myddle, this study encompasses the establishment of parish-based poor relief in 1601 through the waning days of this system in the late eighteenth century. Expanding the analysis of early modern poverty, this study joins conversations concerning English poor law historiography. In contrast to earlier studies of Myddle this examination pushes the historical enquiry into new territory by focusing on poverty, extending analysis into the eighteenth century, and concentrating on gender as a category of analysis as a way of understanding the effects of the poor laws. This study also looks at the implementation of government legislation at the local level, best understood as an interactive process that was influenced by wider social and cultural ideas. Parish chest materials dealing with poor law administration and other parish documents related to poor relief are used along with The History of Myddle, a work of local history written by Myddle resident Richard Gough, to explore the treatment of and views surrounding Myddle's poor. This study explores Gough as a historical figure to show that his position within the parish affected his portrayal of Myddle's poor within his writings. The concept of settlement, a principle central to the poor laws and a major theme within both Gough's writings and parish chest documents, illustrates that belonging in the parish was not a straightforward process, and primarily revolved around one's potential financial risk to the parish. Analyses of illegitimacy and pauper apprenticeship in Myddle further demonstrate that poverty was not a universal experience. The major findings of this study concern the ways in which this flexible system, one that defies easy summation, worked in reality. Significantly, Myddle reveals the localized nature of poor relief before changing ideas about the poor took hold. This led to the enactment of a new poor law in 1834, and a system that was both more uniform and less localized, but nevertheless resulted from a complex evolutionary process. 


\section{DEDICATION}

In memory of the late Robert L. Morgan, who set me on the path, and dedicated to Ryan D. Cutright, who countless times kept me there. 


\section{ACKNOWLEDGMENTS}

I would like to acknowledge the assistance of Ms. Patty Plymale of the Buckhannon, West Virginia Family History Center branch of the Family History Library in Salt Lake City, Utah, who in the very early days of this project went above and beyond in helping me gain access to microfilmed sources relating to Myddle. Second, I wish to express deep gratitude to Ms. Mary McKenzie, along with the staff and volunteers of the Shropshire Archives in Shrewsbury, who all provided valuable access to research materials, advice, and encouragement. The guidance of my committee members, Drs. Kate Kelsey Staples, Katherine Aaslestad, Joseph Hodge, Susannah Ottaway, and Matthew Vester, all of whom have provided invaluable aid during the life of this project, has been both constructive and generous. This dissertation owes particular debt to Dr. Susannah Ottaway, who has supplied substantial assistance both in conceptualizing the project and intellectualizing the transition to the New Poor Law. I also want to recognize my adviser and dissertation chairperson, Dr. Kate Kelsey Staples, whose supervision has never ceased to be enthusiastic, practical, and wise. The help of all of these individuals acknowledged, all misconceptions and inaccuracies are nevertheless my own. Last, I want to express gratitude to several members of my family, including Christina M., Forrest D., Alexandria, Kirk, Kora, and Augustina White; Ricky D. and Wanda L. Cutright; Jonathan R., Jennifer L., Grant, and Emma Morgan; Gregory R. and Pamela L. Morgan; and Ryan D. Cutright. Whether they realized it or not, their patience and encouragement persistently served as the source of inspiration and perseverance. 
TABLE OF CONTENTS

Table of Contents

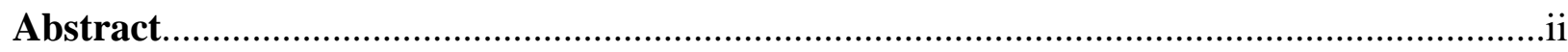

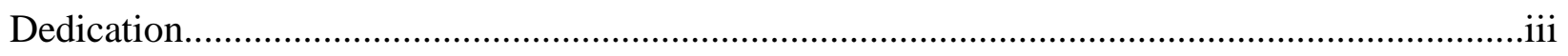

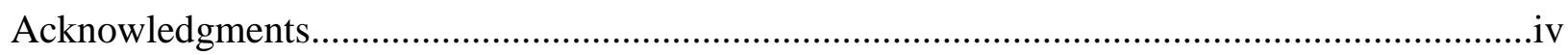

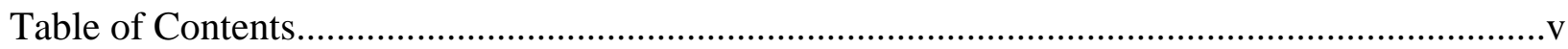

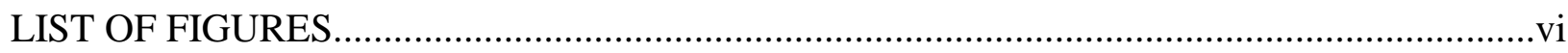

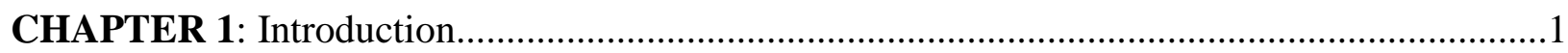

CHAPTER 2: Richard Gough and the Writing of the The History of Myddle .............................36

CHAPTER 3: "No Town Willingly Receives a Poor Man": Settlement in The History of

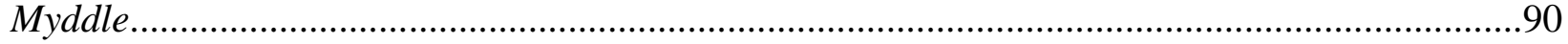

CHAPTER 4: Beyond The History of Myddle: Settlement in the Eighteenth Century.............142

CHAPTER 5: Myddle's "Sparrows": Illegitimacy and the Poor Law System.........................183

CHAPTER 6: "A Twigge Will Best Bend When It Is Greene": Pauper Apprenticeship in

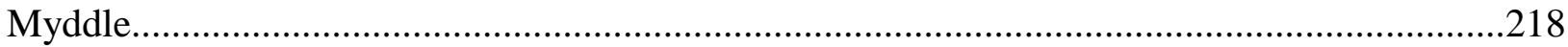

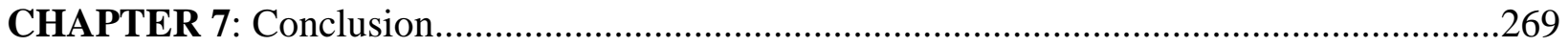

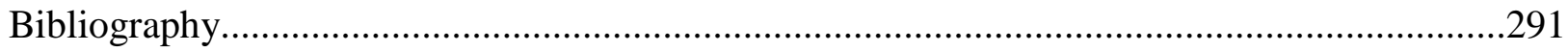




\section{LIST OF FIGURES}

Figure 4.1: Settlement Incidents in Myddle, 1693-1792......................................................154

Figure 4.2: Settlement Certificate Holders and Recorded Dependents in Myddle,

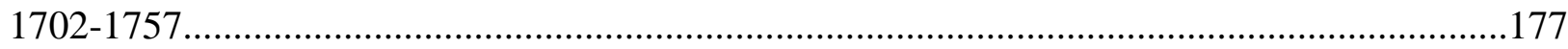

Figure 4.3: Pauper and Itinerant Burials in Myddle, 1600-1800..........................................180

Figure 6.1: Chronological Distribution of Parish Apprenticeships in Myddle, 1672-1800........242

Figure 6.2: Gender Distribution of Parish Apprenticeship in Myddle, 1692-1800...................258 


\section{CHA P T E R 1: I N T R O D UC T I O N}

\section{Introduction}

Not far from Shakespeare's reconstructed Globe Theatre in south London is a cemetery. Now known as Cross Bones Graveyard, from the medieval period until burials there ceased in 1853 due to overcrowding, it was the resting place of thousands of paupers, prostitutes, and society's other disreputable cast-offs. Saved from becoming a building site soon after its closure, the disused cemetery in the twentieth century variously housed a fairground, timber-yard, and industrial workshops. It was then excavated in the 1990s as part of the London Underground Jubilee Line extension. ${ }^{1}$ Since then, the cemetery has inspired a series of plays by the writer John Constable, whose work, reminiscent of medieval mystery plays, aims to tell the putative stories of the forgotten who over the centuries were buried there. ${ }^{2}$ A shrine now exists at Redcross Way, its gates swathed in flowers, ribbons, and countless other tokens of remembrance.

Many would have Cross Bones serve as a symbolic route to our understanding of society's unfortunates. Instead, Cross Bones signifies a double barrier. First, it suggests the constraint particularly relevant to this study: the barrier of time and the limits of the historical record. Second, it symbolizes the mental roadblock to comprehending the poor in our own time. The present poor tend to be perpetually understood in numerical, Malthusian terms. It is an easier task to show the poor of the past our sympathy because, unlike those of our own time, they offer us no threat. Thus, the poor of the past are sympathetic; our sensibilities rest easier when the poor of the present are not. However, the flowers at Cross Bones are also indicative of our difficulties in liberating the past's poor from the boxed systems in which they lived. In other

\footnotetext{
${ }^{1}$ Cross Bones Graveyard, accessed 1 Nov 2017, crossbones.org.uk.

${ }^{2}$ John Constable, The Southwark Mysteries (London: Oberon Books, 2011).
} 
words, we pin up such tributes like those at Redcross Way as symbols of our powerlessness to both save and understand them.

In spite of these limitations, this study, in the interest of moderating any arguments that would focus on the progress or anti-progress of the poor laws and arriving at a deeper understanding of the poor, tries to move beyond the gates at Cross Bones. When Thomas Hobbes wrote in 1651 that the greatest threat to government was "that dissolute condition of masterless men without subjection to laws and a coercive power to tie their hands from rapine and revenge," the political theorist was giving voice to a widespread social anxiety regarding the apparent lawlessness of the itinerant laboring class. ${ }^{3}$ The experiences of these men and women, the focus of my study, ultimately demonstrate the shaky foundations of the early modern parishbased community. The main objective of this project is to explore how concepts of community and belonging within the rural English parish were sharpened by poor law administration through a parochially-based system of relief during the seventeenth and eighteenth centuries. The overarching premise is that the experience of poverty from within was different from its conception from the outside.

Following social historian K. D. M. Snell, I define "belonging," according to the ubiquitous phrase appearing in parish records throughout the early modern period, to be "of this parish." ${ }^{4}$ Since the operation of the poor laws necessitated knowing who belonged to each parish, strongly connected with this connotation are the poor laws and their associated idea of settlement. To be settled in a parish constituted an official recognition of one's membership

\footnotetext{
${ }^{3}$ Thomas Hobbes's expression is a notion that highly influences A.L. Beier's Masterless Men: The Vagrancy Problem in England, 1560-1640 (New York: Methuen \& Co. Ltd, 1985), a key study on early modern vagrancy. Thomas Hobbes, Leviathan: Parts I and II, rev. ed., ed. A.P. Martinich and Brian Battiste (London, 1651; reprint, Buffalo, New York: Broadview Editions, 2011), 168. Also quoted in Beier, 6.

${ }^{4}$ K. D. M. Snell, Parish and Belonging: Community, Identity and Welfare in England and Wales, 1700 1950 (New York: Cambridge University Press, 2006), 17.
} 
within the parish and conferred the right to seek parish relief. For the poor themselves, belonging in this sense was an acknowledgment of their inclusion within the parish community if not in "respectable" society - and served as a legal entitlement to parish support in times of need. I examine such concepts in a microhistorical study of the management of the Elizabethan, or Old, Poor Law within the Shropshire parish of Myddle, a community chronicled in the wellknown work The History of Myddle, written by local historian, antiquarian, and Myddle resident Richard Gough. ${ }^{5}$ My study ultimately highlights the contingent nature of belonging through its examination of the complicated ways in which one's settlement within the early modern English parish was determined. My inquiry pinpoints the factors that affected it, and whether these reflected localized problems, or broader, national ones. For instance, larger forces included important pieces of governmental legislation, such as the 1662 Act of Settlement and various other statutes passed throughout the early modern period; the stresses on the system caused by an increasing rural population in the latter half of the eighteenth century and early part of the nineteenth; and the price inflation associated with the Napoleonic Wars and British trade embargo. ${ }^{6}$ Localized factors included the state of parish finances and how this affected officials' interaction with various types of poor.

Local studies have always had an important place in poor law historiography, primarily due to the general lack of uniformity in poor law administration from parish to parish prior to 1834. My study therefore speaks to previous works that explore such subjects as English poor law history in both a legislative and administrative sense, the day-to-day parochial management of the Elizabethan Poor Law, and the religious and ideological aspects of poverty and social

\footnotetext{
${ }^{5}$ Richard Gough, The History of Myddle, edited and with an introduction and notes by David G. Hey (New York: Dorset Press, 1986).

${ }^{6}$ J. D. Marshall, The Old Poor Law, 1795-1834 (New York: The MacMillan Press Ltd, 1968), 10, 23-25.
} 
welfare. Thus, my investigation - which is, at its most basic level, a local study of poverty moves beyond previous interpretations of this Shropshire community via a more critical reading of Gough's history and by incorporating the experiences of those at the heart of poor law administration, the poor themselves.

This local study of Myddle utilizes a variety of sources, including Gough's abovementioned early eighteenth-century writings. Within The History of Myddle, Gough provides commentary on eight settlement cases involving Myddle and several assorted parishes between 1668 and 1701. Throughout his narrative, Gough betrays a concern over preserving Myddle's financial resources. He additionally communicates larger societal anxieties surrounding the idleness and immorality associated with the poor, those selfsame "masterless men" disparaged by Hobbes. Because of this perspective, Gough discloses no discernable concern for the individual paupers themselves.

I utilize parish chest records in Myddle that deal with poor law administration to complement my analysis of Gough's work, as explained below, along with other types of parochial records. This includes Myddle's parish registers, which record baptisms, marriages, and burials within the parish; parish chest materials; and county-level quarter sessions records. ${ }^{7}$ These types of parochial documents reveal a picture of the relationship and connections between the poor and the parish, something that is often absent from Gough's writings, in which such individuals are frequently understood as a drain on parish resources. Through evaluation of the

\footnotetext{
${ }^{7}$ Myddle Parish (Shropshire), Parish Chest Records, 1671-1920 (Shropshire County Record Office, Shrewsbury), Family History Library (FHL) microfilms 1,702,879 items 24-32; 1,702,903 items 1-8; 1,911,438 items 2-3 (FHL, Salt Lake City, Utah); idem, Parish Registers for Myddle, 1541-1942 (Shropshire County Record Office, Shrewsbury), FHL microfilms 1,701,254 items 9-15; 1,702,085 items 8-16 (FHL, Salt Lake City, Utah); idem, Churchwardens' and Overseers' Accounts, 1735-1936, Including Some Vestry Minutes (Shropshire County Record Office, Shrewsbury), 1,701,619 items 6-7; 1,701,620 items 1-3 (FHL, Salt Lake City, Utah); Court of Quarter Sessions of the Peace (Shropshire), Quarter Sessions Rolls, 1696-1971, XQ/S/5 (Shropshire Archives, Shrewsbury); idem, Quarter Sessions Order Book, 1709-1726, XQ/S/1 (Shropshire Archives, Shrewsbury); idem, Quarter Session Minutes, 1708-1971, XQ/S/3 (Shropshire Archives, Shrewsbury).
} 
concept of settlement and the related problems of vagrancy, bastardy, and the maintenance of pauper children, these records also reveal official attitudes about the poor and uncover how the process of poor law administration functioned within Myddle.

Thematically, this study's aim is not to rescue the poor of history, for that is in many ways a fool's errand and impossible task. I do not presume, for example, that Myddle parish resident Humphrey Beddow was not the lazy, drunken cobbler described by Gough's The History of Myddle. Rather, I seek to give the boundaries of his world proper consideration. In other words, the individuals who populate this study were human. As far as the sources allow, this study tries to contemplate this point. Moreover, poverty, gender, morality, and attitudes about respectability are key threads running throughout this work. Each of these major themes explores assumptions about the poor, differentiates the various experiences poverty, and provides a different - and more circumscribed - picture of belonging.

\section{Parochial Belonging as a Category of Analysis}

It is important to define some of the recurrent ideas within this study, first and foremost poverty, community, and belonging. As well, it is useful to outline what I mean by the terms "parish" and "community," which I use in many ways interchangeably. Another necessary task is to discuss why examining belonging through the analytical lens of the parish is not only appropriate but also crucial to understanding fundamental features of early modern English society. Last, delving into belonging's conceptual weak points helps construct a more helpful model of what it represented to the poor. 
During the medieval and early modern eras, the poor were thought to come from the class of people whose only means of livelihood was their labor. ${ }^{8}$ There were two main types of poor: the déclassé, or "the shameful poor," who were those not usually poverty stricken, tended to be from the upper social orders, and therefore not accustomed to living supported by their own labor, and the laboring, or "structural poor." ${ }^{9}$ The latter type of underprivileged, the focus of this study, was further subdivided into the deserving, indigent poor, that is, the elderly, sick, or disabled, and the undeserving, "temporary poor," or those who fell into poverty mainly due to circumstance. ${ }^{10}$ These sorts of individuals are those to whom the term "poor" is typically directed.

There are a few other important distinctions worth mentioning concerning the poor in early modern England. The upsurge in vagrancy in the mid-sixteenth century, felt not only in England but all across Europe, led to the development of the twin concepts of the deserving and undeserving poor, or those who could not and would not work, and to the passage of various European poor laws reflecting these delineations. ${ }^{11}$ In England, the first law to make an unambiguous distinction between these two types of poor was Concerning Punishment of Beggars and Vagabonds (22 Henry VIII c. 12), which was passed in $1531 .^{12}$ Although not exclusively limited to them, the undeserving poor included "foreigners" or "strangers" who

\footnotetext{
${ }^{8}$ Laurence Fontaine, The Moral Economy: Poverty, Credit, and Trust in Early Modern Europe (New York: Cambridge University Press, 2014), 15-16.

${ }^{9}$ On these points, Fontaine cites Jean-Pierre Gutton, La Société et les pauvres: L'exemple de la généralité de Lyon,1534-1789 (Paris: Les Belles Lettres, 1971), 21, 23-24, 50-53. Fontaine, 17, 17 n. 6; Luciano Allegra, "Becoming Poor in Eighteenth-Century Turin," Journal of Interdisciplinary History, 46, no. 2 (Autumn 2015): 159.

${ }^{10}$ Fontaine, 17.

${ }^{11}$ Jason Philip Coy, "Beggars at the Gates: Banishment and Exclusion in Sixteenth-Century Ulm," The Sixteenth Century Journal 39, no. 3 (Fall 2008): 623 n. 11.

${ }^{12}$ W. E. Tate, The Parish Chest: A Study of the Records of Parochial Administration in England, 3rd ed. (New York: Cambridge University Press, 1969), 190; Paul Slack, The English Poor Law, 1531-1782 (New York: Cambridge University Press, 1990), 51.
} 
would not work. In short, they were the wandering poor, epitomized by the much-vaunted "sturdy beggar" (who could be a man or woman) as well as the mothers of illegitimate children, who all in different ways represented potential burdens to the community and parish. ${ }^{13}$ The deserving poor, on the other hand, were typically those parish residents who for various reasons could not work. Under the 1531 law, the undeserving poor were to be punished, while the deserving poor were given licenses to beg. The law also marked a key step toward the local management of poverty. Justices of the peace, who had previously been charged with the punishment of vagabonds, now came to be responsible for the local impotent poor who possessed begging licenses as well. ${ }^{14}$

Almost certainly exhibiting several of the ideas contained within pamphleteer William Marshall's Draft of a Poor Law (London, 1536), For Punishment of Sturdy Vagabonds and Beggars (27 Henry VIII c.25) further cemented the parish as the center of poor relief. ${ }^{15}$ This law did several things: it echoed the distinction between the impotent and able-bodied poor and outlined that the able-bodied were to be punished and put to work. This emphasis on work extended to poor children, who were to be apprenticed. As for the impotent poor, both begging and "indiscriminate almsgiving" were prohibited, and instead charitable contributions were to be distributed through the parish. ${ }^{16}$

The Elizabethan Poor law of 1601, For the Relief of the Poor (43 Eliz. I c.2) was another key development. This law set up a basic system of poor relief that was not in effect changed until the New Poor Law was passed in 1834. It established a system of poor relief based on the

\footnotetext{
${ }^{13}$ Claire S. Schen, "Constructing the Poor in Early Seventeenth-Century London," Albion 32, no. 3 (Autumn 2000): 451.

${ }^{14}$ G. R. Elton, England under the Tudors, 3rd ed. (New York: Routledge, 1991), 189.

${ }^{15}$ William Marshall, Draft of a Poor Law (London, 1536); discussed in Slack, 7 and Elton, 189-90.

${ }^{16}$ Slack, 9-10.
} 
parish and set up local overseers of the poor and the collection of poor rates, which were used to help the poor. Connected with this system were two basic forms of relief: indoor and outdoor, which, although not static in their aims throughout the early modern period, were tied in some sense to the above distinctions regarding the deserving and undeserving poor. Indoor relief comprised some type of local housing for paupers, which was an option for the able-bodied poor, but was sometimes used to accommodate the impotent poor as well. However, this was only true if a parish had such facilities, which were in effect forerunners of the workhouse, and in the pre1834 period, this was not always the case. Outdoor relief, which was generally given to a parish's deserving, resident poor, involved payment of maintenance in the form of a pension (usually less than a shilling per week, but amounts varied) and sometimes included distributions of fuel, clothing, and other necessaries. ${ }^{17}$

Although this general system of relief gave parishes a fair amount of leeway and flexibility in translating law into action, it was a double-edged sword. Within this system, parish overseers themselves were in a sense overburdened. Their duties included determining the parish of settlement for claimants of relief, obtaining necessary removal orders, providing testimony to local officials in cases where removals were disputed, and collecting and assessing poor rates. ${ }^{18}$ So, though the parish was an administrative unit central to the workings of the Elizabethan Poor Law, it held significant, and at times onerous, responsibilities.

Again looking to Snell, I use the term "parish" with not only its administrative functions in mind, but also as a substitution for the local community. ${ }^{19}$ The English parish, used in both these ways, remained an important entity in English life throughout the early modern period for

\footnotetext{
${ }^{17}$ Anthony Brundage, The English Poor Laws, 1700-1930 (New York: Palgrave, 2002), 14.

${ }^{18}$ Brundage, 13-14.

${ }^{19}$ Snell, Parish and Belonging, 13.
} 
several reasons. In a general sense, parochial attachment appears to have continued as an important touchstone well into the industrial age. ${ }^{20}$ Moreover, the poor laws intensified the parish's influence on the lives of everyday people. Furthermore, Brodie Waddell emphasizes the important point that while Holy Communion had ceased to possess its former unifying "social power" in the post-Reformation period, at the same time, the parish's "economic influence" increased, as "the expansion of the parochial relief system made 'belonging' to a particular locality much more important for many people." 21

What the poor laws created, in essence, was a powerful insider-outsider dynamic that solidified the idea of community and had sweeping effects on ideas of parochial belonging, making parochial belonging arguably even more important than it had been in previous centuries. $^{22}$ For instance, "[t]o be a 'neighbour' or 'citizen,' rather than a 'stranger' or 'foreigner,' had a profound effect on one's economic situation," and the poor laws, with their aims to control vagrancy and the poor's movements, fragmented the economic and mental environment in two: between those who belonged and those who did not. ${ }^{23}$ For these reasons, during the late Stuart period "[c]ommunal festivities, including Rogation processions, revived markedly in many villages, and this coincided with the expansion of parochial poor relief and disputes about 'settlement,"' all of which spurred a renewed shared sense of local identity. ${ }^{24}$ This heightened, ritualized sense of community also developed in tandem with the expansion of a new market economy. The "beating of the bounds" on Rogation Day, for example, ceremonially enforced

${ }^{20}$ Snell, Parish and Belonging, 13.

${ }^{21}$ Brodie Waddell, God, Duty and Community in English Economic Life, 1660-1720 (Rochester, New York: The Boydell Press, 2012), 224.

\footnotetext{
${ }^{22}$ Waddell, 149.

${ }^{23}$ Waddell, 149, 193.

${ }^{24}$ Waddell, 193.
} 
and imprinted the boundaries of the parish within the collective imagination. ${ }^{25}$ Belonging, as understood through the poor laws, was also tied in important ways to life events, since these often created one's settlement in a parish. Because of this, moments like christenings and marriages transcended genealogy or family history.

Expressions of belonging also had significant relationship with local power. This is why Steve Hindle postulates a "'continuum,'" or "'hierarchy,'" of belonging that was shaped by stresses within the community and was at least in part dependent on the decisions of local elites. ${ }^{26}$ Thus, the poor laws permitted belonging to reflect real conditions as well as an idealized form of community, which local elites aspired to create. This was accomplished through the power vested in them by the poor laws to control the local population by keeping out undesirables, who threatened to drain the parish's funds, and directing the local labor market to the benefit of the community and local elites. ${ }^{27}$ Therefore, throughout the early modern period in England, a poor person from a different parish frequently encountered not only suspicion but often "exclusion from the local economic community" when they applied for aid. ${ }^{28}$

There were several ways in which one could "belong." Nevertheless, the poor laws are particularly useful in drawing out this concept for a number of reasons. The source material is most easily read from above, and is imprinted with patterns of local power and authority. However, this does not preclude other interpretations. Though the voice of the documents is

\footnotetext{
${ }^{25}$ Ronald Hutton, The Rise and Fall of Merry England: The Ritual Year, 1400-1700 (New York: Oxford University Press, 1996), 175-76, 217-18, 247; Ronald Hutton, The Stations of the Sun: A History of the Ritual Year in Britain (New York: Oxford University Press, 2001), 277-87; Steve Hindle, "Beating the Bounds of the Parish: Order, Memory, and Identity in the English Local Community, c. 1500-1700," in Defining Community in Early Modern Europe, ed. Michael J. Halvorson and Karen E. Spierling (Burlington, Vermont: Ashgate Publishing, 2008), 205-27; Waddell, 181.

${ }^{26}$ Steve Hindle, "The Problem of Pauper Marriage in Seventeenth-Century England," Transactions of the Royal Historical Society, 6th ser., 8 (1998): 89.

${ }^{27}$ Waddell, 190.

${ }^{28}$ Waddell, 191.
} 
primarily an institutional one, their creation involving parish churchwardens and overseers, and local justices of the peace, it was tempered by wider social and cultural influences, which affected not only the process of negotiation inherent in poor relief but also the particular expressions of the biases within them. ${ }^{29}$ Many of the documents highglight conflicts between the well-off and the poor, but other source material used within this study occasionally also explore other, more horizontal, lines of conflict over reputability and disreputability. Therefore, the delineation of belonging in this parochial, local sense can be incredibly revealing about how parish officials saw their community and the poor who resided within it. It also tells of the interplay between the center and periphery, or how government legislation was interpreted and implemented at the local level. At the same time, though much about the poor laws emphasizes binary distinctions - between insiders and outsiders, the deserving and undeserving poor, as a few examples - the records themselves help to uncouple some of these ideas. Above all, they show that belonging often hinged on a confluence of factors that was contingent upon each pauper's personal situation and life story. A place of privilege unmistakably informs many of the sources used in this study, and the vantage point of them often occludes the voices of the poor. Still, it must be recognized that they reflect an aspirant order, and as such often hint at both the hardship and incessant wandering that marked the lives of the poor. They also murmur of a messy reality lying underneath the source material. In short, they disclose that just as there was no one way to be poor, one's poorness, in turn, often influenced one's place in the community and degree of belonging.

Even though belonging is an idea that accesses ideas of community and the ways in which poverty was negotiated, it has several conceptual weaknesses. First, the poor probably

\footnotetext{
${ }^{29}$ Peter D. Jones, "'I Cannot Keep My Place without Being Deascent': Pauper Letters, Parish Clothing and Pragmatism in the South of England, 1750-1830," Rural History 20, no. 1 (2009): 33.
} 
conceptualized their belonging in other, non-parochial ways, possibly valuing the bonds they formed within alternative communities of others, doubtless stuck in the same plight, who assisted them in "making shift." Second, the notion of "being of the parish" implies stability, when it was instead unstable, especially for the poor, and the concept can frequently blind us to how the poor experienced it. This study highlights these limits, and explores it in several ways: via attitudes regarding morality and respectability, through the legal concept of settlement and as a means of legal parish support, and as an instrument used by parish officials at the local level to manage the parish's resources as it related to relief expenditure. In many of these senses - and probably most of the time - belonging was out of the poor's control. Nonetheless, exploring the idea that poor, parish, and belonging were not always equivalent reveals how the poor laws affected each of these concepts. In fact, it is in its margins that the analytical value of belonging rests. Its subjective nature and variability are what give it historicity. If the answer to the question of what belonging meant to the poor is difficult to ascertain, what belonging meant for them is in contrast identifiable to a much greater degree.

\section{Poor Law Historiography and Conceptual Framework}

Quite long and complex in its history, poor law historiography can be divided into several chronological and methodological schools. The first interpretations were tied to administrative history. For decades, the writing of British history tended to focus on the seventeenth-century struggles between the Crown and Parliament, the growth of Constitutionalism, and above all, the sweeping national Whiggish narrative of linear progress. Such history served up an insular story seen through the narrow lenses of political and constitutional history. By and large, administrative histories of the English poor laws tended to see the above developments as evidence of increasing governmental centralization, and accordingly placed them within the 
narrative of the growth of the early modern English state. Furthermore, while early poor law studies unavoidably discussed the indigent themselves, they tended to appear "as illustrations of policy in practice rather than as individual people with an existence outside the framework of parochial relief." ${ }^{30}$

One key figure of the early administrative school was George Nicholls, author of $A$ History of the English Poor Laws in Connection with the State of the County and Conditions of the People (1854). ${ }^{31}$ Nicholls himself was a member of the Poor Law Commission set up to administer the New Poor Law of 1834 and wrote histories of the Irish and Scottish Poor Laws in addition to his work on English poor law administration. ${ }^{32}$ Poor law history was often written with an agenda, and another administrative approach was offered up by poor law historians and Fabian socialists Sidney and Beatrice Webb. The Webbs, whose studies of the English poor laws are regarded as seminal works in the field, were also reformers and used the voluminous amount of poor law administrative documentation to argue for the abolition of the repressive poor law system in their volumes, English Poor Law History. ${ }^{33}$

The early 1960s marked a key break in the administratively-focused approach to British history, during which time British Marxist historians like Christopher Hill, Eric Hobsbawm, and E. P. Thompson, disenchanted with the narrowness of traditional political and constitutional history, used a variety of approaches, including those gleaned from demography and sociology,

\footnotetext{
${ }^{30}$ Alannah Tomkins and Steven King, eds. The Poor in England, 1700-1850: An Economy of Makeshifts (Manchester: Manchester University Press, 2003), 2.

${ }^{31}$ George Nicholls, A History of the English Poor Law in Connection with the State of the Country and the Condition of the People, vol. 1, A.D. 924 to 1714, rev. ed. (1854; reprint, New York: Augustus M. Kelley Publishers, 1967).

${ }^{32}$ Brundage, 3-4.

${ }^{33}$ Brundage, 4; Sidney Webb and Beatrice Webb, The Parish and the County, vol. 1, English Local Government (London: Longmans, Green and Company, 1906); idem, English Poor Law History, Part I: The Old Poor Law, vol. 7, English Local Government (London: Longmans, Green and Company, 1927).
} 
to focus more on both economic matters and the lives of everyday people. The Marxist social historians tended to see the poor laws as part of Britain's capitalist transformation and in doing so charted the growth of capitalism and the consequent class struggles it produced. ${ }^{34}$ Often times their ambitions included the reconstruction of this perceived "lost" pre-industrial and precapitalistic world. $^{35}$ Though mindful of the role of the state, they fundamentally re-wrote the largely nonviolent and neat Whig story so as to more accurately portray the social unrest, class struggle, and negotiation that they believed was central to understanding eighteenth- and nineteenth-century society. ${ }^{36}$

The 1960s and 1970s also signified an important shift in poor law studies "from centre to locality." ${ }^{37}$ This also meant that whereas most historians had up to that point focused on social and political elites, Marxist-social historians attempted to reconstruct the lives of the lower classes as well as to catalogue their economic and political exploitation. ${ }^{38}$ The distinguishing feature of this approach to the poor laws was that "the poor themselves [were] the focus rather than those who legislated or administered." ${ }^{39}$ Therefore, these types of local case studies were geared more toward studying phenomena like unemployment, migration, and mobility rates. ${ }^{40}$

\footnotetext{
${ }^{34}$ Brundage, 4.

${ }^{35}$ Peter Laslett's The World We Have Lost: Further Explored, for instance, is an example of both a demographic approach and this general sentiment ([New York: Charles Scribner's Sons, 1984]). Laslett belonged to the influential Cambridge Group for the History of Population and Social Structure, which was founded in 1964. Gareth Stedman Jones, "History and Theory: An English Story," Historein: A Review of the Past and Other Stories 3, no. 1 (2001): 105, 111. See also Fontaine, 2.

${ }^{36}$ Catherine Hall, "The State of Modern British History," History Workshop Journal 72 (Autumn 2011): 206.

${ }^{37}$ Anne Digby, Pauper Palaces (London: Routledge \& Kegan Paul, 1978), ix.

${ }^{38}$ Brundage, 6.

${ }^{39}$ Brundage, 6.

${ }^{40}$ Snell, Parish and Belonging, 83.
} 
Snell is one of the most important social historians of poor law and explores the uses of settlement examinations, which consist of interviews meant to establish the proper parish of settlement for individuals who were deemed likely to seek poor relief and whose residency was in some way questionable. Snell notes that despite their primarily "legal purpose," such documents often serve as "short biographical accounts of agricultural, artisan and urban workers," evidence of the type that rarely makes it into the historical record. ${ }^{41}$ Indeed, in a significant study, Annals of the Labouring Poor: Social Change and Agrarian England, 16601900, Snell himself uses such records to track trends including seasonal unemployment among both men and women and the decline of both the "living-in" system and apprenticeship. In the process, Snell provides compelling evidence for the deteriorating condition of the laboring rural class in the eighteenth and nineteenth centuries. ${ }^{42}$ Snell's work can therefore be seen as an attempt to add quantitative weight to the basic thesis put forward in Thompson's field-changing work, The Making of the English Working Class, which had cataloged, albeit in more impressionistic terms, the deteriorating situation of the laboring class and the Industrial Revolution's "attack on skill."43

If social history had nudged the study of the poor laws away from a centralized and primarily national paradigm, the influences of postmodernism and cultural history further decentralized the historical narrative. For example, Gareth Stedman Jones argues that the history presented by social historians was just as insular as the traditional history it supplanted, the

\footnotetext{
${ }^{41}$ K. D. M. Snell, "Settlement, Poor Law and the Rural Historian: New Approaches and Opportunities," Rural History 3, no. 2 (1992): 150.

${ }^{42}$ K. D. M. Snell, Annals of the Labouring Poor: Social Change and Agrarian England, 1660-1900 (New York: Cambridge University Press, 1985).

${ }^{43}$ E. P. Thompson, The Making of the English Working Class (New York: Vintage Books, 1966).
} 
blinkered and proverbial "island story."44 Their studies also fixated on class and the Industrial Revolution as forming the foundation of British identity, to the expense of other forces, like race, gender, religion, or national and local ties. In a similar recognition of the limits of social history, Giovanni Levi maintains that the model of pre-modern society put forward by Thompson, in which a "moral economy" regulated economic forces and the greed of speculators, is in essence a conservative one that obscures the dynamism inherent in peasant society. ${ }^{45}$ As well, an important critique of social history was that it obscured "the individual human dimension" through "the language of number" in its demographic focus. ${ }^{46}$ Additionally, in his study of poverty in Bolton, Lancashire during the late seventeenth century, Jonathan Healey recognizes the limits of one of social history's most favored means of understanding poverty: the concept of life-cycle poverty, or the idea that poverty could be tied to certain life events, such as old age or widowhood. For Healey, one of the key drawbacks to the life-cycle approach was that it could make poverty seem deterministic. ${ }^{47}$ Healey finds that in Bolton, instead "unpredictable factors, notably family breakdown and sickness ... had the biggest impact in terms of creating poverty as relieved by the poor law." 48

\footnotetext{
${ }^{44}$ Stedman Jones, 113.

${ }^{45}$ Levi writes that he wishes to study a different "historical reality," as differentiated from "the slow extinction of a social system due to the aggressive consolidation of centralized power in an absolute state or to the widespread diffusion of market forces," that emphasizes the inevitable - and teleological - victory of capitalism. Giovanni Levi, Inheriting Power: The Story of an Exorcist, trans. Lydia G. Cochrane (Chicago: University of Chicago Press, 1988) xiii-xiv; E. P. Thompson, "The Moral Economy of the English Crowd in the Eighteenth Century," in Customs in Common: Studies in Traditional Popular Culture (New York: The New Press, 1993), 185258).

${ }^{46}$ Brundage, 2-3.

${ }^{47}$ Jonathan Healey, "Poverty in an Industrializing Town: Deserving Hardship in Bolton, 1674-99" Social History 35, no. 2 (2010): 126.

${ }^{48}$ In particular, family breakdown and widowhood emerge as key determiners of parish-relieved poverty in Healey's study of Bolton. Healey, 144-45.
} 
Some scholars, after the "linguistic turn," attempted to investigate poverty and poor relief as detached from categories of analysis, like class, that they felt some historians had lapsed into viewing as static. They also desired to view the poor laws as more than merely a means of battling deviance and enforcing conformity. Cultural historians examined poverty in terms of more matters like ideology, identity, and the inner workings of the relationship between the poor and parish officials. For example, Paul A. Fideler writes that historians such as Paul Slack, A. L. Beier, Margo Todd, Ole Peter Grell, along with himself, "have argued that ideology and what pre-industrial people actually were thinking about poverty and the best responses to it must be put back into the history of social welfare's development." ${ }^{49}$ In addition, Fideler argues that studies focusing on late medieval and early modern religion, such as the works of Miri Rubin, Ronald Hutton, and Eamon Duffy, are thus similarly useful for understanding poverty and the development of social welfare due to "their close associations with customary, parish-centered religious belief and practice. ${ }^{150}$

Likewise, Robert Jütte is influenced by those social historians who have ceased "viewing the emergence of the welfare state as the work of some reformers and governments and turned their attention instead to the rather complex role of the community and the poor themselves in the growth and development of the welfare state. ${ }^{51}$ Thus, scholars like Fideler and Jütte move away from seeing poverty "in terms of governmental regulation and social control." ${ }^{52}$ Many of

\footnotetext{
${ }^{49}$ Emphasis added. Paul A. Fideler, Social Welfare in Pre-Industrial England: The Old Poor Law Tradition (New York: Palgrave MacMillan, 2006), 6.

${ }^{50}$ Fideler, Social Welfare, 6.

${ }^{51}$ Robert Jütte, Poverty and Deviance in Early Modern Europe (New York: Cambridge University Press, 1994), 3.

${ }^{52}$ Jütte, 3.
} 
such studies also highlight the protean nature of identity as well as the negotiation frequently involved in poor relief.

For example, Kate Crassons considers ideas about poverty in the medieval period by relying on contemporary literary sources, and her outline of the various ways of understanding poverty and imaginative use of sources inspire my project. ${ }^{53}$ Crassons's convincing interweaving of medieval and modern sources to demonstrate the recurrent - and often identical - discussions societies have regarding poverty is an especial influence on this study. For the early modern period, Hindle's On the Parish?: The Micro-Politics of Poor Relief in Rural England, c. 15501750 attempts to bring together the national scope and local narratives of poor law administration by exploring the relationships inherent in England's welfare system. ${ }^{54}$ In this work, Hindle delves into the compound workings of poor relief, and underscores both pauper agency and the complicated and non-binary nature of settlement and belonging, key issues within my project. $^{55}$ Similarly, Snell's essays in Parish and Belonging: Community, Identity and Welfare in England and Wales, 1700-1950 move outside the realm of traditional social history to examine more cultural issues like parochial identity and how settlement laws shaped one's concept of home. ${ }^{56}$ As well, Snell ultimately reveals the poor's deep attachment to their parishes in surviving pauper letters, as well as their knowledge and exploitation of settlement to achieve their own ends. Undoubtedly influenced by Thompson's stressing of the robustness of plebeian culture, Snell

\footnotetext{
${ }^{53}$ Kate Crassons, The Claims of Poverty: Literature, Culture, and Ideology in Late Medieval England (Notre Dame: University of Notre Dame Press, 2010).

${ }^{54}$ Steve Hindle, On the Parish?: The Micro-Politics of Poor Relief in Rural England, c.1550-1750 (New York: Oxford University Press, 2004).

${ }^{55}$ Hindle, On the Parish, 362-63, 445.

${ }^{56}$ Again, Snell's work speaks to E. P. Thompson's, here in the sense that Snell argues that parochial identity could sometimes conflict with and supersede a purely class-based sense of identity, a phenomenon he terms "local xenophobia." Snell, Parish and Belonging, 28-80, 81-161.
} 
importantly demonstrates that governmental legislation was not something solely imposed upon the poor; rather, it was also used by them: they were knowledgeable and legally shrewd enough to occasionally take advantage of the system for their own benefit. ${ }^{57}$

Other scholars have revisited some of Thompson's influential ideas on the moral economy. Primarily an economic history, Laurence Fontaine's The Moral Economy: Poverty, Credit, and Trust in Early Modern Europe, examines the contours of an early modern economy that was comprised of competing and interacting aristocratic and capitalistic merchant financial systems in which "solidarities" formed the basis of economic transactions. ${ }^{58}$ Fontaine aso envisions poverty as a process that was characterized more by fluidity than "rigid categorization. ${ }^{59}$

But it is perhaps Waddell, in God, Duty and Community in English Economic Life, 16601720, who most successfully revises the Thompsonian thesis. Waddell, resting heavily on Thompson's concept of a moral economy, studies the relationship between economics and morality in early modern England, and highlights the influences of culture and morality in the economic sphere. ${ }^{60}$ Waddell's key question is how to balance the economic and cultural: was one merely a veil for the other, with economic self-interest at the root of all behavior, or was moral authenticity attached to things such as poor relief? ${ }^{61}$ Using period tracts, pamphlets, ballads, sermons, and catechisms, Waddell's answer appears to be both "yes" and "no." It is in the interstices that the different manifestations of these motivations (as influenced at different

\footnotetext{
${ }^{57}$ Snell, Parish and Belonging, 88-89, 91. See also Thomas Sokoll, ed., "Pauper Letters as a Historical Source," in Essex Pauper Letters, 1731-1837 (New York: Oxford University Press, 2001), 1-9; Peter D. Jones, 3133.

${ }^{58}$ Fontaine, 2-3, 5-6.

${ }^{59}$ Fontaine, 17.

${ }^{60}$ Waddell, 2.

${ }^{61}$ Waddell, 1-23.
} 
moments by economics, moral concerns, changing attitudes toward the poor, and gender) upon which a reality-based - and it must be said, messy - reconstruction of late Stuart life rests. ${ }^{62}$ Local studies of Myddle itself have similarly varied in their interpretations. The most comprehensive is David G. Hey's An English Rural Community: Myddle under the Tudors and Stuarts, a social history upon which my study seeks to build. ${ }^{63}$ Hey attempts a reconstruction of Myddle's population, its various social classes, and landholding patterns. However, my study differs from it in employing a narrower focus on Myddle's poor and utilizing a wider framework that incorporates cultural attitudes, something not satisfactorily addressed in this earlier study. On the whole, my investigation accords with the assertion of Robert Mayer in his 1996 article, "'The History of Myddle': Memory, History, and Power," in which Mayer sees Gough's history as principally a study in how power functioned within an early modern rural community. Mayer writes that Gough's work, one that takes its organizational cue from the seating plan of the parish church pews, as more than a simple springboard for the mere reassembling of late seventeenthand early eighteenth-century life in Myddle. Instead, it represents a richer and much more byzantine "inscription of local power." 64

A further important assessment of the The History of Myddle as a historical source is that Gough's own prejudices, which frequently reflect those of the propertied classes, create a false impression of stability in Myddle, as pointed out by Henry French. In short, French argues that Gough's The History of Myddle communicates an air of changelessness because Gough generally

\footnotetext{
${ }^{62}$ Waddell, 21-22.

${ }^{63}$ David G. Hey, An English Rural Community: Myddle under the Tudors and Stuarts (Leicester: Leicester University Press, 1974).

${ }^{64}$ Similarly, in Gender and Space in Early Modern England, Amanda Flather notes that because pew seating was according to social standing, the effect of Gough's choice to write his history based on pew seating was to mirror the social order. Amanda Flather, Gender and Space in Early Modern England (Rochester, New York: The Boydell Press, 2007), 135; Robert Mayer, "'The History of Myddle': Memory, History, and Power," Studies in Philology 93, no. 1 (Winter 1996): 65-66.
} 
discusses the families who had both remained and prospered in Myddle, whereas the lives of the lower orders were in contrast marked by unpredictability, itinerancy, and familial and economic instability. ${ }^{65}$ Thus, French argues, the families that make up the bulk of the The History of Myddle owe their presence primarily to "the accident of longevity." ${ }^{66}$ I might add to this assertion that when Gough does include commentary on Myddle's poor, these individuals are frequently seen through the poor law's parochial prism.

In addition to focusing predominantly on the poor, rather than the full community of Myddle as Hey does in his local history, this study incorporates some features of microhistorical analysis in order to understand the poor in early modern England. The attention of microhistory is fixed on a smaller scale, to the "little things" or "little people" whose stories, which often emanate from the margins, have the ability to reveal larger truths. ${ }^{67}$ Microhistory is a subfield deeply influenced by Clifford Geertz's concept of "thick description." ${ }^{68}$ As well, stemming from Edoardo Grendi's concept of the "exceptional normal," ${ }^{69}$ is the fundamental idea that unusual documents can make clear the larger historical perspective. ${ }^{70}$ Local history, in contrast, is the study of one place or region that relies on a large and diverse set of sources in order to examine

\footnotetext{
${ }^{65}$ Henry French, "'Ancient Inhabitants': Mobility, Lineage and Identity in English Rural Communities, 1600-1750," in The Self-Contained Village?: The Social History of Rural Communities, 1250-1900, ed. Christopher Dyer (Hatfield: University of Hertfordshire Press, 2007), 75.

${ }^{66}$ Henry French, 80.

${ }^{67}$ Richard M. Tristano, "Microhistory and Holy Family Parish: Some Methodological Considerations," U.S. Catholic Historian 14, No. 3 (Summer 1996): 26.

${ }^{68}$ Clifford Geertz, "Thick Description: Toward an Interpretive Theory of Culture," in Interpretation of Culture (New York: Basic Books, 1973), 3-30; Thomas Kuehn, "Reading Microhistory: The Example of Giovanni and Lusanna," The Journal of Modern History 61, no. 3 (September 1989): 515; Tristano, 26.

${ }^{69}$ Edoardo Grendi, "Micro-analisi e storia sociale," Quaderni Storici 35 (1977): 506-20. See also Carlo Ginzburg's discussion of this idea in: Carlo Ginzburg, "Microhistory: Two or Three Things That I Know about It," trans. John Tedeschi and Anne C. Tedeschi, Critical Inquiry 20, no. 1 (Autumn, 1993): 33.

${ }^{70}$ This is a nuanced idea, however. Kuehn writes that the happenings examined through the lens of microhistorical analysis "are presented not in the manner of a functionalist exposition, where a part stands for the whole, but as sui generis, though still illuminating of their historical context." Kuehn, 515.
} 
the development of a given locality usually over a long span of time. ${ }^{71}$ The differences between the two methodologies lie in microhistory's methodological attempt to uncover new interpretations, whereas local history tends to be descriptive and hew to traditional narratives.

As this study is a local study of poverty, this work is also a local history. It is microhistorical in several important senses. Utilized here are a limited number of sources, which concentrate on the problem of poverty. As well, this study focuses on individuals primarily from one social class - the "little people" - rather than on the broad sweep of Myddle's society, which is Hey's primary emphasis. And, although the limitations of the sources occasionally allow but often hinder the telling of their individual stories, class is examined - and indeed is a major focal point - but the differing experiences of the individuals who made up the lower orders are emphasized over homogeneity. Another theme in microhistory is the interplay between popular and elite culture. ${ }^{72}$ Exploring the dealings between parish elites and the poor assesses these types of interactions. Finally, a major premise here is that Gough's source, although decidedly unusual, is an "exceptionally-normal" one that unintentionally exposes the interrelations between the local framework and wider cultural ideas about poverty, gender, and respectability, revealing how thorny an issue belonging sometimes was.

Therefore, in contrast to the previous studies of Myddle, my project fills a key gap by using poor law documentation in conjunction with Gough's local history, an extraordinary and unusually colorful source, to explore ideas about poverty in Myddle, how they changed over time, fit in with or deviated from the major ideological shifts elaborated in the secondary

\footnotetext{
${ }^{71}$ In terms of English local history, the subfield is associated with the work of W. G. Hoskins, of whom Hey was a student.

${ }^{72}$ In fact, Ginzburg's work investigates and questions the utility of these very concepts. Carlo Ginzburg, The Cheese and the Worms: The Cosmos of a Sixteenth-Century Miller, trans. John Tedeschi and Anne Tedeschi (Baltimore: Johns Hopkins University Press, 1980); Tristano, 27
} 
literature, and were affected by factors such as one's family size, marital status, age, and gender. The use of both local records and Gough's history in tandem allows me to reevaluate the narrative presented in each in order to demonstrate the complex nature of poverty in the early modern period. In short, if Mayer and French recognize that The History of Myddle is reflective of power and shrouds the lives of families whose residence and lineage were neither "ancient," prosperous, nor respectable, my study concurs with their observations. Unlike them, however, I attempt to go beyond this observation. The primary drive of this study is to deconstruct the historical sources in order to reconstruct the outlines of that concealed world, one that sits beneath the surface of both Gough's work and Myddle's parish records.

Regarding a wider approach, my study aligns with several of the above methodologies. It focuses on negotiation as a way of understanding poverty in seventeenth- and eighteenth-century England of scholars, as do Fideler, Jütte, and Crassons. In its fundamental aim of a comprehensive re-examination of The History of Myddle, my study supports some of the arguments of Snell and Hindle. This work also owes much to the basic philosophy of Waddell in its wish to present an interpretation of early modern England that is more dynamic and less Manichean than the Thompsonian narrative. In this view, it is not so much a "moral" economy perennially struggling against an eventually-victorious "market" as a sphere of interrelated - if at times still competing - moral economies. Waddell convincingly argues:

The binaries that can be found embedded in so much of the work on these themes [late Stuart values] have impeded our ability to understand the diversity and complexity of past beliefs. By attempting to compress a whole panoply of different social and cultural norms into two antagonistic 'economies,' Thompson and many of his successors have produced a deeply problematic representation of both early modern thinking and economic relations in this period. We must disaggregate these supposedly dichotomous ideologies and, in so doing, demonstrate the inadequacy of unilinear trajectories of change. The vigour and 
variety of late Stuart 'moral economies' are simply too profuse to be contained within the limited confines of the conventional model. ${ }^{73}$

Therefore, to differentiate itself from Thompson's conceptualization of a dualistic plebeian culture beset by patrician attempts at control, given voice in the modern age by a "history of below," poor law administration is here seen as opening up the space for interaction between "high" and "low" cultures, creating a series of transactions - oftentimes dictated from those above to those at the bottom, but occasionally emanating from the other direction and providing glimpses of what life what like for the poor of this period. ${ }^{74}$

I depart from some of the above-mentioned scholars in significant ways. Similar to the essays within Snell's Parish and Belonging, I emphasize the parish as an important administrative unit and a primary source of identity. This study complements the general sweep of Snell's argument concerning the cultural importance and organizational persistence of the parish well into the modern period, yet I explore poverty and its instigation of parochial destabilization. In other words, if the parish was "real" and a central administrative and conceptual unit in people's lives, it was also at times an unstable construct. ${ }^{75}$ In contrast to Snell's reading of belonging, which he tends to view broadly and more inclusively, when employed here, it is more likely to be used in an exclusionary sense, often in a discussion of how someone was deemed not to belong. Part of this is due to the nature of the source material under investigation, but this is also because I examine belonging in ways that Snell's work on the parish either does not consider or downplays. For some people, the parish did not always equate with

\footnotetext{
${ }^{73}$ Waddell, 20.

${ }^{74}$ This idea also takes a cue from David Cressy's imaginative study of life rituals in Tudor-Stuart England. David Cressy, Birth, Marriage, and Death: Ritual, Religion, and the Life-Cycle in Tudor and Stuart England (New York: Oxford University Press, 1997), 9.

${ }^{75}$ Snell, Parish and Belonging, 13-14.
} 
belonging. Consequently, when it is interrogated, some of its instability is revealed through the experiences of the poor, who often found that the ground shifted underneath them and could seemingly be arbitrarily included or excluded. A superficial reading of the records conveys administrative neatness, just like Gough's tidily-drawn map of Myddle's parish church. Dwelling beneath, however, is the untidiness of poverty.

Like Hindle, I explore the highly localized nature of poor relief under the Elizabethan Poor Law. ${ }^{76}$ Yet, I expand Hindle's analysis by relying upon gender as a category of analysis in order to survey both the workings of power in Myddle and the diverse experiences of poverty among various groups of people, including the male and female able-bodied poor, single agricultural laborers, married men and women, families, the elderly, and children. In short, extending Hindle's analysis of poor law administration, of it as both a product of negotiation and influenced by patterns of local power, further shows the slipperiness of belonging as well as the individualized and gendered nature of poverty. The records from Myddle show the ways various types poor people experienced poverty, but it must be recognized that belonging itself was also gendered in very important and fundamental respects, through differing expectations of male and female members of the community in terms of respectability, and thus operated in ways that have not yet been fully appreciated.

\section{Research Questions}

The focus of this study is on the ways in which the poor laws affected ideas about community. A more specific goal is to explore The History of Myddle as a historical source and what it reveals about a small community in early modern England. My research questions are

\footnotetext{
${ }^{76}$ Hindle terms these variations "local ecologies of relief" that depended on topography, social structure, the size and vitality of the local tax base, and the munificence of local gentry - or even middling parishioners - that might enable the financial support of local charitable organizations. Hindle, On the Parish, 282-95.
} 
particularly focused on the work's views on the poor, and in what ways parish documents complement or diverge from the sentiments put forward by Gough.

Additionally, this study investigates what pushing the limits of Hey's earlier study topically, chronologically, and thematically does to the basic understanding of Myddle. For example, this study looks at a longer time period, pushing the enquiry to the end of the eighteenth century, when Myddle and several other parishes made the decision to form a union to administer poor relief, a choice that at that time was an uncommon one, in order to expand an analysis of the vehicle of historical change in Myddle. In contrast to Hey's work, this also represents a more focused study of one facet of Myddle and incorporates aspects of microhistorical analysis and cultural and gender history.

Broader questions include examining how a study of poor law administration in Myddle fits within both poor law historiography and general views of the Elizabethan Poor Law. Another contextual part of this study is opening up the nature of the interaction between the local and the center, not only in terms of legislation but also regarding wider social and cultural ideas. Epitomized by Thompson's idea of a pre-capitalist moral economy, explored here is the way in which larger ideas were given form in a specific, local context. Last, this study surveys the end point of parochial poor relief in the lead-up to the New Poor Law in 1834 and asks what this meant for both the idea of community and the poor themselves.

\section{Sources and Methodology}

Gough's The History of Myddle along with parish poor law administration records are the main units of analysis in this local study of poverty. Since this is fundamentally a study of ideas about poverty, I tend to use the types of sources that are likely to reflect these impressions about the poor, rather than other types of sources, such as rents, for example. Additionally, because 
Hey's earlier work on Myddle was comprehensive, this study, attempting to build on Hey, differs in its more concentrated focus on poor law administration, the poor, and ideas about poverty.

My sampling strategy includes all extant parish chest records dealing with poor law administration in Myddle prior to 1800. This includes archival records pertaining to settlement, bastardy, apprenticeship, overseers' and churchwardens' accounts, and vestry minutes, with an eye to teasing out the cases of particular individuals mentioned across various documents. This allows for a more complete analysis of their stories, something which the sometimes perfunctory nature of legal and parochial records - the sources typically employed in this type of analysis renders a challenging, indeed often impossible, endeavor. ${ }^{77}$

A case in point is the family of Humphrey Beddow, whose story stretches across several documents, including the records of the Shropshire quarter sessions, tax records, various sorts of parish chest documents, as well as being subject to lengthy and nattering commentary by Gough himself. Beddow's penury, for example, is well documented in the 1672 Shropshire hearth tax, on which he appears as a pauper deemed exempt from taxation. ${ }^{78}$ Gough concentrates on a dispute between the parishes of Myddle and Cardington over Beddow's settlement taken up at both the January 1667/8 and Easter 1668 quarter sessions. First, Beddow's settlement case highlights the fact that the concept of settlement was a gendered one: for men, one's place of employment as well as the terms of one's hiring contract were often important factors in

\footnotetext{
${ }^{77}$ This reliance on case studies, in an effort to transcend the social historian's dependence on "the collective dimension" and delight in statistics over individual stories, owes much to Bronisław Geremek's pioneering study, The Margins of Society in Late Medieval Paris, trans. Jean Birrell (New York: Cambridge University Press, 1987), 95.

${ }^{78}$ Shropshire Archaeological and Parish Register Society, The Shropshire Hearth Tax Roll of 1672: Being a List of the Householders in the County (Shrewsbury, Shropshire: n.p., 1949), FHL microfilm 453,027, item 1 (FHL, Salt Lake City, Utah), 205.
} 
establishing settlement in ways that they were not for women. ${ }^{79}$ From the point of view of Myddle's parish officials, Beddow's place of birth and the parish where he served out his apprenticeship - Cardington in both instances - mitigated his settlement in Myddle. Second, Beddow's case is also symbolic of a theme that runs throughout Gough's The History of Myddle, and one that was clearly a larger societal concern: the idleness of the able-bodied poor, an anxiety that had grown since at least the fourteenth century. For instance, Gough criticizes Beddow for sinking into dependence and becoming an "idle beggar" after suffering from an unspecified illness, while beforehand Beddow had been able to support himself through his work as a cobbler. ${ }^{80}$ Ultimately, this example demonstrates how, despite its status as a legal principle, settlement was essentially fluid, and a product of negotiation, something clearly demonstrated within parish and other local records. Beddow's case very clearly illustrates the ways in which the sources present multiple opportunities for interpretation. For example, although it was eventually set out that several conditions bestowed settlement - the serving of parish office,

\footnotetext{
${ }^{79}$ This was because either an apprenticeship or one-year's service bestowed settlement within one's parish of employment. Although apprenticeship and hiring contracts also affected women's settlement, upon marriage, they earned her husband's parish of settlement. This did not work the other way around for males. For a work that explores the ways in which poverty was a gendered experience, see Sharon Farmer's Surviving Poverty in Medieval Paris: Gender, Ideology, and the Daily Lives of the Poor, a study that in many ways can be seen as a more up-todate adjunct to Geremek's above-referenced work, in its in its cultural bent and attention to gender and class as key categories of difference that complicated the traditional conceptions of the poor as a cohesive - even united class. Moreover, Farmer feels that studies of charity and works outlining medieval standards of living — that is, traditional social history - provide "some idea of who was at risk of falling into dire poverty, and of the types of poor people whom propertied individuals preferred to assist, but they tell us little about how the poor actually lived and survived," an assertion with which my project supports. Sharon Farmer, Surviving Poverty in Medieval Paris: Gender, Ideology, and the Daily Lives of the Poor (Ithaca: Cornell University Press, 2002), 5-6.

${ }^{80}$ The story by no means ends here. Gough mentions the apprenticing of Beddow's son by parish officials, lamenting that the parish had twice set the boy as an apprentice, only to have him run away and end up in prison, which is partly confirmed in the 1684 apprenticeship indenture of Daniel Beddow to Richard Lockley of the parish of Clive, and signed by Gough himself. Because, as the Justices of the Peace record, "Humphry Beddow of the parish of Myddle in the County of Salop hath a greate charge of small children which he is not able to mainteine without Releife and Assistance from the said parish," the minister and churchwardens for Myddle arranged Daniel Beddow to be set as an apprentice to Lockley as a carpenter (Myddle Parish Chest Records, 1671-1920, Apprenticeship Indentures, 1672-1891, Apprenticeship Indenture of Daniel Beddow [13 March 1684]). An even more interesting series of settlement cases involving Beddow's daughter and son-in-law, Elizabeth Davies and William Gittins, is catalogued, which are similarly traceable through various archival records. Gough, 251-53, 25658.
} 
hiring for a one-year period, or being bound an apprentice, for instance - these qualifications marked areas of consideration in determining one's settlement, but they were of course far from absolutes. $^{81}$

I also make use of period sources of various types, including relevant pieces of poor law legislation, the writings of political thinkers and reformers, prescriptive literature, and ballads, both to reveal contemporary attitudes and, where possible, help balance the paucity of the poor's voice in official records. Many of these sources are accessible from the collections available through Early English Books Online and the seventeenth-century English Broadside Ballad Archive at the University of California Santa Barbara. ${ }^{82}$ I use these types of sources in conjunction with The History of Myddle in order to determine the degree to which Gough reflects wider, long-standing collective anxieties about the problem of poverty, but also to help give shape to the experiences of Myddle's poor. At times, some of these sources provide alternative views not only to those of the individuals writing poor law legislation at the center, but also to the gentry and substantial land holders, that is, the individuals who made up the "local oligarchy" typified in Myddle by the local Justices of the Peace and parish churchwardens and overseers, ultimately men like Gough himself. $^{83}$

\section{Limitations}

Source material represents the most significant restrictions of this study involve the source material. First, conclusions are based on events that were recorded in the first place. They are limited in the additional sense that they comprise those documents that managed to

\footnotetext{
${ }^{81}$ Nicholls, 324.

${ }^{82}$ Early English Books Online, https://eebo.chadwyck.com/home; English Broadside Ballad Archive, University of California Santa Barbara, https://ebba.english.ucsb.edu/.

${ }^{83}$ J. R. Poynter, Society and Pauperism: English Ideas on Poor Relief, 1795-1834 (Toronto: University of Toronto Press, 1969), 9-10, 24.
} 
make their way into the parish chest to be preserved for posterity. Second, the sources predominantly assert a top-down, institutional view. As well, because of their purpose the documents tend to give the impression of stasis, and that the basic parish community "core" held. ${ }^{84}$ This conclusion is, on the surface, accurate. Yet, it must be remembered that each settlement examination, removal order, and settlement certificate represented contests over the nature of that "core" and claims on belonging that were not always upheld. They show how membership in the parish community was being challenged, and that with each pauper apprenticeship and bastardy bond, it was also being negotiated. Moreover, the eighteenth century in particular was one in which Myddle saw change. After the 1720s, symbolically just after Gough's lifetime, pastoral farming gave way to arable, many of the small tenements that had made up the backbone of Myddle's social structure were absorbed, and the divide in the parish between the poor and the prosperous widened. All of the records examined here reflect some of these challenges at a time when demands on the parish's role in poor relief were increasing. ${ }^{85}$ Third, the biased nature of these documents means that the poor's voice is obscured, or at the very least appears muffled and indirect. A related problem is that the documents used here tend to emphasize the poor's vertical relationships, concealing the types of horizontal family and social connections that would have allowed them to adapt to and survive the difficult circumstances they often encountered. ${ }^{86}$ As a result, care must be taken to remember informal networks of relief that sometimes have made it into the historical record but

\footnotetext{
${ }^{84}$ See Snell's configuration of "Settlement and Belonging in an Eighteenth-Century Parish," which depicts a parish community core surrounded by the poor, paupers, and certificate holders. Snell, Parish and Belonging, 94 fig. 3.1 .

${ }^{85}$ Hey, An English Rural Community, 5-6, 230-31.

${ }^{86}$ Jeremy Boulton for instance discusses the risk of overestimating the significance of institutional relief for the poor. Jeremy Boulton, "'It is Extreme Necessity That Makes Me Do This': Some Survival Strategies of Pauper Households in London's West End during the Early Eighteenth Century," International Review of Social History 45 (Supplement) (2000): 47-48.
} 
more often than not, have not. ${ }^{87}$ Differing perceptions are similarly problematic, as it was possible that parish elites conceived of belonging in terms of property ownership and labor, while the poor envisaged it in alternate ways that were less connected with place and more so to family and other social ties. Last, is the danger that all historians must face: that making use of case studies might give rise to oversimplification. ${ }^{88}$

Although the purpose and nature of the historical sources make recovering what the poor themselves thought about events difficult, they nevertheless enable the uncovering of the nature of the poor law system in Myddle. They also enable reflections of popular fears about the poor while at the same time allow for the differentiating the different types of poor and their experiences. Though in many ways a top-down work, Gough's The History of Myddle helps in moderating both the biases within and brevity of Myddle's parochial poor law documentation. For instance, Gough's work is unique work since it discusses people of all social orders, and even though it reflects his relatively privileged position, Gough appears transparent about Myddle's social problems. In addition, despite the fact that they tend to be more impressionistic than detailed about the poor, the sources do at times reveal vivid snapshots of their lives. Additionally, other types of sources are used to support some of the conclusions drawn from individual stories. This study takes seriously Fontaine's view that "what matters however is not the abundance or paucity of sources. The essential is to reformulate in the present as we live it the questions thrown up by the past, a dialogue necessary to shape our common future." ${ }^{89}$ Through many twists and turns, the intellectual principle underlying the Old Poor Law lead to

\footnotetext{
${ }^{87}$ Waddell, 186.

${ }^{88}$ Brundage for example points out that all scholars "employing a narrower geographic, chronological, or topical framework must confront the problem of generalizing from their case studies." Brundage, 2.

${ }^{89}$ Fontaine, 7.
} 
the present, and my study endeavors to highlight not only the continued relevancy of poverty but also the fact that we are heirs to the end of Myddle's story.

\section{Significance}

Due to the great diversity in the management of poor relief across England's parishes which are estimated to have numbered in excess of 14,000 - scholars have long diagnosed the difficulty in coming to any sort of synthesis regarding Elizabethan Poor Law administration. ${ }^{90}$ This is why the review of its functioning at the local and regional level has assumed such significance, studies that have had an extensive scholarly tradition. ${ }^{91}$ My study helps satisfy the continued need for local case studies of this type. It also contributes to the revising of traditional assumptions regarding the multifaceted intra- and inter-parish workings of poor relief in early modern England. For example, much of the debate about the Elizabethan Poor Law has centered on whether the familiarity of the parish system, which was run by local parochial overseers and eventually replaced in 1834 by the workhouse system and more bureaucratic Poor Law Unions, bred greater sympathy for the poor, or greater contempt.

My project demonstrates through a focus on Myddle's lower classes, a population for whom life was frequently marked by instability, itinerancy, and the tenuous notion of community. At the same time, I explore the threat represented by the poor to not only the parish's limited resources but also to the entire social order, which in the eighteenth century revolved heavily around property ownership as well as values like industriousness and respectability.

\footnotetext{
${ }^{90}$ James W. Ely, Jr., "The Eighteenth-Century Poor Laws in the West Riding of Yorkshire," The American Journal of Legal History 30, no. 1 (January 1986): 2; Steven King, Poverty and Welfare in England, 1700-1850: A Regional Perspective (Manchester: Manchester University Press, 2000), 269.

${ }^{91}$ Though not meant to be exhaustive, examples of several such studies are mentioned within the bibliography. On the importance of local studies within poor law historiography, see J. D. Marshall, 11-12.
} 
Finally, it is inevitable that any investigation into poverty is in some sense an interrogation into the past as well as our own society. In the fourteenth century, William Langland observed that "[s]ome spent their lives at the plough, and were seldom idle, / Seeding and sowing and strongly labouring / To gather what the gluttony of wastrels would again scatter (Prologue, 20-22)." ${ }^{12}$ Whether society's wasters be late medieval beggars or modern-day "welfare queens" who throw the harvest of respectable society to the wind, the subjects of poverty and poor relief remain nothing if not relevant. What all of these preconceptions share is the collective - and timeless - failure to understand the poor.

\section{Organization}

Organized both topically and chronologically, my project is subdivided into five principal chapters. Chapter two, entitled "Richard Gough and the Writing of the The History of Myddle," explores the figure of Gough, including his personal life and place within the community of Myddle, as well as how his background influenced the structural and descriptive narrative of his local history. Within it, I also argue that The History of Myddle was shaped by wider cultural forces, and thus was a document of historical specificity. Throughout the next four chapters, I investigate various facets of poor law administration within Myddle. For example, the third chapter, "'No Town Willingly Receives a Poor Man': Settlement in The History of Myddle," includes a discussion of the historical background concerning the Elizabethan Poor Law and other key pieces of successive legislation. I then continue the analysis of Gough's writings by examining the eight settlement cases that are outlined within The History of Myddle and cover the period $1668-1701$.

\footnotetext{
${ }^{92}$ William Langland, Piers Plowman: The Prologue and Passus I-VII of the B-Text, ed. Terence Tiller (Ware, Hertfordshire: Wordsworth Editions Limited, 1999), 3.
} 
Having laid the groundwork of the argument for understanding Gough's historical narrative as primarily the work of a parish elite, later chapters explore poor law administration in Myddle, keeping in mind that the surviving documentation was written from this same viewpoint. For example, "Beyond The History of Myddle: Settlement in the Eighteenth Century," the fourth chapter, persists in surveying the concept of settlement through investigation of additional parish chest materials. Such documents include approximately seventy-one settlement examinations (1702-1808), fifty-six removal orders (1683-1792), and forty-five settlement certificates (1702-1757).

In order to further untangle the life of the parish poor, I examine within chapter five, "Myddle's 'Sparrows': Illegitimacy and the Poor Law System," how the early modern parish dealt with the issue of illegitimacy. I explore its financial consequences in terms of poor relief through investigation of Myddle's parish registers and nineteen extant bastardy bonds (17101778). The usual way of recording an illegitimate birth was through the parish register, whereas bastardy bonds resulted from the interviewing of an unwed mother by local officials. Bastardy bonds represented the attempt to consign responsibility for the financial support of an illegitimate child on the shoulders of the father, rather than the parish. Illegitimacy was explicitly linked to the concept of settlement, as a child's parish of birth dictated the parish responsible for his or her relief. The parish, therefore, had a vested interest in offloading this responsibility through a variety of means. ${ }^{93}$ Here, I emphasize the important social and legal implications of illegitimacy, including its strain on parish finances and impact on settlement, as well as gendered ideas about culpability and respectability.

\footnotetext{
${ }^{93}$ This included forcing the father, if born in a different parish, to marry the mother in order to ensure the child's legitimacy, and thus the family's settlement, within the father's parish. Tate, 218.
} 
In "'A Twigge Will Best Bend When It Is Greene': Pauper Apprenticeship in Myddle," chapter six, I similarly look at the parish management of pauper children by surveying the onehundred and fifty surviving apprentice indentures (1672-1891), forty-six apprenticeship bonds (1672-1752), and apprenticeship registers (1803-1804) within the parish. Of this group of sources are included the approximately twenty-seven bonds (1672-1701) relating to the apprenticeship charity set up by William Gough, the uncle of The History of Myddle author, Richard Gough, who also served as the charity's trustee. ${ }^{94}$ Local parish officials frequently set out pauper children, sometimes in places far away from home, in order to stem the costs of directly supporting the child. The process of pauper apprenticeship was one which saw many poor children sent away from their home parishes. Such records consequently speak to a number of topics, including gender, ideas about community, and the impact of charity on a community's poor.

My concluding chapter presents a synthesis of poor law administration in Myddle, arguing that the evidence presents an amalgamated system. For both the parish officials who were tasked with deciding who was a resident and who was not, and for the poor themselves, settlement was contingent upon many factors. A fundamental theme is to what degree the narrative presented by Gough variously reflects, and at times obscures, a world that was in flux. Another important goal of this study is exploring the classic paradigm of continuity versus change, or the consideration of perceivable shifts in the treatment of the poor over time. A traceable process of change began in the eighteenth century and saw culmination with the passage of the New Poor Law in 1834.

\footnotetext{
${ }^{94}$ Will of William Gough, Gentleman of Sweeney, Shropshire, 4 May 1669, PROB 11/329/509, Prerogative Court of Canterbury Wills, 1384-1858, The National Archives, Kew, Richmond, Surrey; Hey, An English Rural Community, 178.
} 
CHA P T E R 2: R I CHAR D G OUGH A N D THE W R I T ING OF THE HISTORY OF MYDDLE

\section{Introduction}

Richard Gough's The History of Myddle is an early eighteenth-century local history of the Shropshire parish in which the author lived. Despite his attempt to impose a veneer of uniformity onto Myddle's history, reality appears to have been much more uncertain and disorderly than Gough's narrative seems to suggest. Although Gough's work communicates a somewhat flexible system of morality, in which goodness is not always limited to community elites, its classification of morality intrinsically favors the more well-to-do residents of the community. Moreover, these are the individuals whom Gough himself is more likely to judge favorably and unsurprisingly garner most of his attention. Gough's world is one in which an individual can rise to respectability or fall into disreputability and bad seeds occupy even the most dominant families in his history of Myddle. Despite this, he communicates a clear hierarchy in which certain groups are preferentially treated. In the end, The History of Myddle describes only a certain kind of Myddle, and despite the appearance of impartiality, Gough's work is best appreciated as a subjective catalog of Myddle's residents.

In a broader sense, Gough's local history is clearly a document of historical specificity that reflects wider societal predilections and anxieties. These beliefs clearly affect Gough's depiction of the poorer classes of Myddle, who are often portrayed as lazy, drunken, and immoral. This chapter examines Richard Gough as a historical figure both through his personal history and place within the community of Myddle and how his background and culture influenced the structural and descriptive narrative of his local history. In the process, the findings also reveal the contingent nature of belonging. While other parts of this study explore belonging through consideration of the parish as an administrative unit via the central role it 
played in poor relief, here, through an exploration of Gough's text, this concept is investigated in a moral sense and as it was mediated by class, gender, and ideas about respectability.

Such analysis reveals that Gough singles out several qualities for special praise, such as involvement in the community and parish affairs through office holding, industriousness and hard work, occupational skill and competence in managing property, prudence, charity to the less fortunate, hospitality, friendliness, and amiability towards one's neighbors. At the same time, he details several sources of conflict within the community, such as theft, deceit, domestic violence, and alcoholism, the last being the social ill to which Gough gives the most space. Gough also passes judgment on wastefulness, the mismanagement and squandering of estates, laziness, and selfishness. Although examples abound of well-off individuals who wasted their estates through drink and profligacy and those who had little attaining honor through hard work, Gough's dogged focus on landholding means that respectability is primarily seen through the lenses of property and pedigree. In such a highly ordered class-based society, gender also constituted an important dynamic. Women were expected to conform to their gendered place by being productive and conscientious housewives, un-quarrelsome wives, and good mothers. Their role in disrepute was a double-edged one, as a woman was not only accountable for her own behavior, but that of her entire family. Women could tempt men to sin, and their responsibilities as mothers meant that their children's character defects were their responsibility. By describing the personal history of Gough, observing how he came to write The History of Myddle, and deconstructing its text, this chapter shows that Gough, far from being an idiosyncratic figure, reflected the gendered and class-based norms of the late seventeenth and early eighteenth centuries. 


\section{Preindustrial Rural England: Contested Interpretations}

Much as the nineteenth-century peasant poet John Clare remembered youth's rosycolored bliss, there has been a tendency to envisage the preindustrial English rural community as a pastoral and bucolic world untouched by the horrors wrought by industrialization. ${ }^{1}$ This idyllic rural life was primarily disrupted by enclosure, which was largely achieved through a parliamentary government representing the interests of the middle- and upper-class property owners and lawyers. Enclosure was a process that English working class historian E. P. Thompson terms the wholesale "class robbery" of England's agricultural laborers. ${ }^{2}$ Concentration on the troublesome forces of modernity too often obscures the exact nature of the traditional culture that was eventually overlaid by the new industrial order. Thompson himself explores this issue, arguing that there was active resistance to the forces of change. In his archetypal conception, at the same time as the old communal order was replaced, rendering England's laboring classes "strangers in their own land," the process of resistance solidified class consciousness and forged the identity of the English working class in the period roughly surrounding the years 1780 to $1832 .^{3}$

Despite its enormous influence, Thompson's thesis has been questioned. For example, some scholars charge that by focusing on the formation of a collective working class identity, both the divisions and exclusion that marked English traditional rural culture is not adequately

\footnotetext{
${ }^{1}$ See, for example, Clare's "Joys of Youth": "How pleasing simplest recollections seem / Now summer comes it warms me to look back / In the sweet happiness of youths wild track / Varied and fleeting as a summer dream ... " John Clare, "[Joys of Youth]" in Major Works, ed. Eric Robinson David Powell (New York: Oxford University Press, 2008), 46.

${ }^{2}$ Clare is also a familiar figure for his criticism of enclosure, most famously in his poem "Helpston Green." Clare, 62-64; E. P. Thompson, The Making of the English Working Class (New York: Vintage Books, 1966), 12, 218.

${ }^{3}$ E. P. Thompson, Customs in Common: Studies in Traditional Popular Culture (New York: The New Press, 1993), 184.
} 
considered in the classic Thompson narrative. ${ }^{4}$ However, this critique rests more with the impression created by this narrative of the preindustrial past than it does with Thompson himself, who in his later work speaks to both sides of the argument. On the one hand, Thompson's outlining of the process that forged the solidarity of the working class infers that there had existed a fairer and more stable system that was cleaved by the engine of industry. At the same time, his well-known cataloguing of a preindustrial moral economy simultaneously highlights class tensions and sources of conflict, key forces that defended "custom" and thus helped balance preindustrial society. ${ }^{5}$

These qualifications aside, the concept of preindustrial communities have sometimes been perceived as characterized by egalitarianism and stability and as embodying a clear rupture point between the "traditional" and "modern." 6 These notions seems to have endured not least because the post-industrial period was characterized by such a high degree of mobility, which was consequently contrasted with a past that was perceived as more permanent and intransient, as well as generally more pleasant. ${ }^{7}$ In this way, the chaos engendered by the Industrial Revolution thus demanded nostalgia for a supposed older uniformity. ${ }^{8}$ In reality, the allegory of

\footnotetext{
${ }^{4}$ English local historian K. D. M. Snell, for example, chooses to look at the mitigating factor of local xenophobia as it relates to the creation of class-based solidarity. K. D. M. Snell, "The Culture of Local Xenophobia," Social History 28, no. 1 (January 2003): 1-30.

${ }^{5}$ This second point is nuanced and somewhat counterintuitive: such conflict was seen as regulatory, in that it was meant to restore order - to bring down the price of grain, for example.

${ }^{6}$ John Mathieu, History of the Alps, 1500-1900: Environment, Development, and Society, trans. Matthew Vester (Morgantown, West Virginia: West Virginia University Press, 2009), 11. See also idem, 155-56.

${ }^{7}$ Early modern historian Ronald Hutton has written on the similar predisposition among folklorists to look for the roots of modern rituals in much older customs. Hutton argues, using the most obvious example of Christmas, that many traditions that are generally thought of as quite ancient date only from the post-industrial period. Those experiencing industrialization "turned instinctively to traditional festivities as relics of a time of greater order, deference, and harmony ..." Ronald Hutton, The Stations of the Sun: A History of the Ritual Year in Britain (New York: Oxford University Press, 1996), 112; Alan MacFarlane, et al, Reconstructing Historical Communities (New York: Cambridge University Press, 1977), 1.

${ }^{8}$ Clare and his contemporaries can also be seen as embracing and romanticizing the more natural — and even rude - qualities of English rural life, which had previously been put down as coarse and uncivilized. They
} 
the unchanging English rural village, untouched by both time and conflict, is now recognized as a modern fiction, and industrialization only strengthened and intensified the divisions that had already marked English society. ${ }^{9}$ Mobility, for instance, was but an old problem with a new intensity. Furthermore, there were certain segments of the English rural population who had always been considered in some sense "strangers" in their own land.

In the preindustrial period, that land was manifested in the bounded world of the parish. Nowhere is this world made more alive than in the early eighteenth-century local historian Richard Gough's The History of Myddle, conceived and written as a local history of the various families populating this rural Shropshire community. From a close reading of Gough's work, it is clear that it principally recounts the history of Myddle's propertied and respectable classes. However, while it communicates a relatively ordered world and certain degree of community cohesion, below the surface of the text a very different space exists, one that this study wishes to examine. Far from being an egalitarian domain, in Gough's version, the early eighteenth-century parish was one that operated around property ownership and emergent middle-class morality and respectability. While some importance was still placed on communal values and the social system had certainly become more flexible, in that respectability was possible for those of the lower classes and moral failings like idleness cut across class boundaries, there were often limits as to which particular individuals could cross the threshold of the reputable classes. ${ }^{10}$

simultaneously championed a distinctively English cultural tradition. Mina Gorji, "Clare's 'Merry England,"' The John Clare Society Journal 24 (July 2005): 6.

${ }^{9}$ On this first point, see for example: Christopher Dyer, ed., The Self-Contained Village?: The Social History of Rural Communities, 1250-1900 (Hatfield: University of Hertfordshire Press, 2007).

${ }^{10}$ Brodie Waddell for example notes that "[i]dleness was abhorrent irrespective of one's social position." Brodie Waddell, God, Duty and Community in English Economic Life, 1660-1720 (Rochester, New York: The Boydell Press, 2012), 97. 
Boundaries of various kinds could be quite rigid, a characteristic that Gough's local history demonstrates in several key ways. First, Gough discriminates in a pragmatic sense about which families and individuals to include in his narrative. In order to appreciate this more contentious picture of a preindustrial community, it is therefore necessary to appreciate the historicity of Gough's narrative and examine his family's history in the parish, Gough's own experiences, as well as wider considerations, for all of these factors informed Gough's methodology. Second, and in a more nebulous ethical sense, he differentiates between those he regards as decent and reputable. For this reason, it is essential to analyze what types of individuals and moral qualities Gough both praises and condemns, with the intention of laying out his conception of the parish community. In these senses, Gough's work adds important qualifications to traditional, bucolic ideas about pre-industrial English life, reveals societal tensions that were importantly both class and gender-based, and in the process complicates the concept of a unified moral economy.

Both due to the sheer amount of information it contains and the richness of Gough's commentary, The History of Myddle is without a doubt one of the most important historical sources describing English rural life in the early modern period, and it is therefore understandable why the significance of it is widely recognized. In fact, David G. Hey, an editor and scholar of Gough's work, goes so far as to christen The History of Myddle "the most remarkable local history ever written." ${ }^{11}$

Tellingly, Gough begins by emphasizing the interconnectedness of land and social standing. ${ }^{12}$ He then sets about describing the families of Myddle, pew by pew. Through his

\footnotetext{
${ }^{11}$ David G. Hey, "Introduction," in The History of Myddle, Richard Gough (New York: Dorset Press, 1986), 7.

${ }^{12}$ Richard Gough, The History of Myddle, edited and with an introduction and notes by David G. Hey (New York: Dorset Press, 1986), 77.
} 
journey around the pews of the Myddle parish church, Gough records the rich family life and social connections that made up this small Shropshire parish and is astonishingly comprehensive. Research by Hey has shown that although Gough concentrates mostly on Myddle's parish gentry, in the end, he manages to write about "nearly everyone. ${ }^{13}$ Nonetheless, comprehensiveness should not be conflated with evenhandedness, and Gough's book is not an integrative or unbiased representation of Myddle, for Gough is not only choosy about which families he includes in his history, but also comments freely upon the moral character of those individuals whom he does decide to take into account. He is for example quick to note which families are morally upright, such as the generally skillful, prudent, and industrious family of William Watkins, as well as those who fell prey to the vices of laziness, drunkenness, and thievery, such as Thomas Jukes, whom Gough reports had three sons but "never a good one." ${ }^{14}$ Moreover, Gough's objectiveness must be read as tempered by the fact that the individuals and families he admires tend to be either from the upper classes or are those who, through their activities and behavior, uphold parochial and communal order.

Likewise, the text is interpolated with references to conflict both within Myddle and outside it. For instance, Gough speaks of personal disagreements, like those between Thomas Atcherley and Humphrey Hanmer and John Downton and William Formston over rights to parish church pews, the second of which was passionate enough to result in Formston breaking the lock off the pew door. ${ }^{15}$ Such incidents hint at class-based tensions. The case of the Atcherleys and Hanmers represented a conflict between elite families in the parish, while the disagreement between Downton, who was from a noble family owning a sizeable farm in the

\footnotetext{
${ }^{13}$ Hey, "Introduction," The History of Myddle, 9.

${ }^{14}$ Gough, 114-15.

${ }^{15}$ Gough, 94-95, 117.
} 
parish, and Formston, a surname associated with tenant farmers, was perhaps between social unequals.

Various other types of disputes between residents are also mentioned, such as the quarrels between Thomas Jukes and Sir Humphrey Lea. These arguments, according to Gough, stemmed from games of lawn bowls, where both men usually "parted in wrath" before again becoming fast friends within a few days. ${ }^{16}$ More fundamentally, Gough additionally records several disagreements occurring between Myddle and other parishes and writes at length about eight inter-parish disputes that range in date from 1668 to 1701 and revolve around the settlement of poorer members of the community who were eligible for parish poor relief under the pre-1834 Old Poor Law. ${ }^{17}$ (Such cases are examined in detail in chapter three.) Mention of the English Civil War is also interspersed throughout the text, as are hints to religious tensions. There is frequent comment upon people both moving in and out of the parish, and Gough also writes in depth about Myddle's relationships with other parishes. Myddle is therefore not presented as an idealized and self-contained rural community.

The work also speaks to ideas concerning community and identity. The History of Myddle sheds light both on how the community functioned in reality and was morally envisaged. Although there are segments of the community that Gough treats cursorily and judgmentally, Gough's general comprehensiveness is compounded with representativeness to some of the attitudes of his day. For example, while Gough lays out an unexpectedly flexible system of morality in which respectability is not limited solely to community elites, it nevertheless stacks the system in the favor of Myddle's more prosperous classes, around whom the entire social order revolves. This means that those who for various reasons are judged as either unimportant

\footnotetext{
${ }^{16}$ Gough, 97.

${ }^{17} \mathrm{Hey}$, "Introduction," The History of Myddle, 12.
} 
or unfavorable are largely left out of Gough's historical narrative. Here, Gough wields morality and respectability as tools to demarcate which certain individuals were included in the world of the parish, while he draws others outside its boundaries, the same methodology parish officials employed in their work administering the poor laws of the period.

This interpretation of Gough's The History of Myddle revises the one presented by David G. Hey's An English Rural Community: Myddle under the Tudors and Stuarts, the sole fulllength study of Myddle published to date. Hey's study represents a social history of Myddle that essentially argues that Myddle was marked more by stability than change. ${ }^{18}$ On the contrary, there seems to have been considerable change. Serving as just one example, demographic figures indicate, and as Hey himself notes, that Myddle's population grew from 270 in the sixteenth century to 450 by the beginning of the eighteenth. ${ }^{19}$ Additionally, Gough also seems to express concern about the increase in those on parish relief. Other studies, including this one, are in contrast more appreciative of such dynamics.

For example, Henry French, in a more recent analysis of Myddle, recognizes that the families and individuals upon whom Gough chooses to concentrate are largely responsible for this impression of permanence. ${ }^{20}$ Despite his apparent liberality in conferring respectability, Gough fundamentally writes in a top-down manner. Therefore, Gough's work represents merely

\footnotetext{
${ }^{18}$ Hey qualifies that although Myddle was no "rural paradise," neither was it an excessively violent society. This, however, ignores other types of disagreements and strife. Hey, "Introduction," The History of Myddle, 23; David G. Hey, An English Rural Community: Myddle under the Tudors and Stuarts (New York: Leicester University Press, 1974).

${ }^{19}$ Hey, "Introduction," The History of Myddle, 22.

${ }^{20}$ Henry French notes that a high population turnover in Myddle involved those of the lower classes and points out that Gough's history communicates an air of changelessness because Gough generally discusses the families who had both remained and prospered in Myddle. Henry French, 'Ancient Inhabitants': Mobility, Lineage and Identity in English Rural Communities, 1600-1750, in The Self-Contained Village?: The Social History of Rural Communities, 1250-1900, ed. Christopher Dyer (Hatfield: University of Hertfordshire Press, 2007), 75.
} 
one way in which Myddle can be envisaged. ${ }^{21}$ In short, the study of other segments of Myddle's population clearly yields a different image of the community. Robert Mayer likewise concludes that Gough's work primarily depicts a "Foucauldian power grid" that reflects the division of local power in Myddle. $^{22}$ Due to his particular focus, Mayer thus emphasizes discord in Myddle, in tandem highlighting the sometimes "litigious bent" of its residents. In doing so, he gives a more dynamic reading of the evidence than does Hey. ${ }^{23}$ As well as the richer methodology utilized by Henry French, the present study thus follows from the crucial realization that it is only the story of a certain kind of Myddle that Gough tells. His writings reveal two very different places. On the one hand are Myddle's various property owners, reputable inhabitants, and active members of the parish community. These types of people represent the foil to Myddle's poorer inhabitants, who due to their landlessness, itinerancy, and perceived laziness and immorality often found themselves placed outside the bounds of the parish community.

\section{The Historical and Economic Context of Myddle}

This study concerns Myddle less as a physical place than as a mental construct.

Nevertheless, wider historical currents were still important to Myddle's story. Important changes include the gradual transition from a society comprised of orders to a more class-based one. As well, early modern legislation affected the role of the parish in poor relief in significant ways. The mid-seventeenth century in particular saw parish administration increasingly controlled by the gentry and wealthy farmers, both as a consequence of the conclusion of the English Civil

\footnotetext{
${ }^{21}$ Marilyn Strathern comments that the very definition of community is dependent on class and in constant flux: "If we refer to models of the village in terms of its social structure, it is clear that different segments conceive of its division and integration in different ways. ... Far from being successfully 'imposed' from above, the notion of 'community' thus meets with resistance. Marilyn Strathern, "The Village as an Idea: Constructs of Village-ness in Elmdon, Essex," in Belonging: Identity and Social Organisation in British Rural Cultures, ed. Anthony Cohen (Manchester: Manchester University Press, 1982), 253.

${ }^{22}$ Robert Mayer, "'The History of Myddle': Memory, History, and Power," Studies in Philology 93, no. 1 (Winter 1996): 70.

${ }^{23}$ Mayer, 65.
} 
War and new poor law legislation passed after the Restoration in 1660. Additionally, local and regional economic patterns and the basic character of landholding and social structure in Myddle all bear mentioning in order to situate Gough and his writings into their proper historical context.

As Keith Wrightson outlines, the conversion in England from a society constructed of orders, or estates, to one characterized by class, a process that began in earnest in the sixteenth century, was encouraged in England by three particular developments. First, due to the Reformation, the clergy - those who prayed - came to be considered less a legal and distinct "estate" and more as a profession. ${ }^{24}$ Second, due to military advances that rendered mounted fighting less important to military tactics, the consequent professionalization of soldiers, and changing definitions of "gentility," the basic character of the knightly class - those who fought evolved towards an ideal that valued citizenship and ruling through humanistic government. ${ }^{25}$ The great breadth of the third estate - those who worked - had often complicated its usefulness as a category even during the Middle Ages, but growing inequality and the growth of an oligarchical yeomanry created greater divisions within it. ${ }^{26}$ Though the eighteenth century witnessed a variety of social categorizations, and earlier terminology like "ranks," and "degrees" proliferated alongside new ones like "sorts," according to the basic Thompsonian model, the process by which the English working class was made would be completed in the period between

\footnotetext{
${ }^{24}$ Keith Wrightson, "Estates, Degrees, and Sorts: Changing Perceptions of Society in Tudor and Stuart England," in Language, History and Class, ed. Penelope J. Corfield (Cambridge, Massachusetts: Basil Blackwell, Inc., 1991), 36.

${ }^{25}$ Wrightson, "Estates, Degrees, and Sorts," 37-38.

${ }^{26}$ Penelope J. Corfield, "Class by Name and Number," in Language, History and Class, ed. Penelope J. Corfield (Cambridge, Massachusetts: Basil Blackwell, Inc., 1991), 120, 128; Wrightson, "Estates, Degrees, and Sorts," 41-42.
} 
c. 1790 and 1832 as the various types of working classes eventually solidified into a single working class. ${ }^{27}$

Occurring alongside the above developments, the effects of the English Civil War had important ramifications for the poor laws during the mid-seventeenth century. The general tumult, disruption, and flourishing of radical ideas that were associated with the Civil War gradually gave way to the restoring of order, whereby:

[p]roperty triumphed. Bishops returned to a state church, the universities and tithes survived. Women were put back into their place. The island of Great Bedlam became the island of Great Britian, God's confusion yielding place to man's order. . . Milton's nation of prophets became a nation of shopkeepers. ${ }^{28}$

In this re-established order, an emphasis on property rights and the power of the gentry - the class that would control poor law administration throughout the early modern period underscored stability. ${ }^{29}$ Additionally, associated with the middle classes and aimed simultaneously against the upper and lower classes was the vociferous condemnation of idleness. ${ }^{30}$ Put another way, the events of the seventeenth century had cemented together the gentry and well-to-do yeoman farmers, at the same time as they dissociated the middling sort from the poorer members of their communities. ${ }^{31}$ This alliance was significant in that it created the avenue through which state authority expanded in new ways into the parish. ${ }^{32}$

Though parish officials' power had been established earlier in the century churchwardens and overseers of the poor sat in control of poor law administration and had the

\footnotetext{
${ }^{27}$ Thompson, The Making of the English Working Class; Corfield, 112, 123-25.

${ }^{28}$ Christopher Hill, The World Turned Upside-Down ([London]: Maurice Temple Smith, 1972; reprint, New York: Penguin Putnam Inc, 1991), 379.

${ }^{29}$ Hill, 330.

${ }^{30}$ Hill, 324-41.

${ }^{31}$ John Walter, "The Impact of the English Civil War on Society: A World Turned Upside-Down?" in Crowds and Popular Politics in Early Modern England (New York: Manchester University Press, 2006), 192.

${ }^{32}$ Walter, 192.
} 
power to fix local rates, for example - the settlement laws expanded their reach in the midseventeenth century. ${ }^{33}$ Thus, mobility was something over which parish officials had a good deal of control. The settlement laws that worked in tandem with the Old Poor Law system had an important effect on migration, reducing the ways one could gain settlement in a parish to five basic routes, all of which could be controlled in some way by parish elites: through employment as a servant for one year, serving an apprenticeship, renting property worth more than $£ 10$ per annum, paying local rates, or by settlement certificate, which meant that an individual resided in one parish while his or her home parish, which was responsible for paying any future poor relief, was in another. ${ }^{34}$

In many ways, Myddle was insulated from some of the most deleterious effects of the early modern period. Shropshire's economy was mainly pastoral. Connected with the Welsh cattle trade, a system of drovers' roads crossed from Wales through Shropshire to the south. ${ }^{35}$ To give an idea of the scale of livestock husbandry's predominance in the county, only eight out of 297 holdings had more value in crops than livestock according to inventories from the $1550 \mathrm{~s}^{36}$ Myddle's economy sat within and was geared toward this larger one, with networks of exchange developing with several local market towns, including Wem, Oswestry, and the county town of Shrewsbury, with its many sheep, wool, and cattle markets. ${ }^{37}$ In contrast to areas where arable farming was prevalent, Myddle's pastoral economy meant that the community was not

\footnotetext{
${ }^{33}$ Dorothy Marshall, The English Poor in the Eighteenth Century: A Study in Social and Administrative History, 1662-1782 (1926; reprint, Abingdon, Oxfordshire: Routledge, 2007), 79.

${ }^{34}$ Thomas Sokoll, "Institutional Context: The Practice of Non-Resident Relief," in Essex Pauper Letters, 1731-1837 (New York: Oxford University Press, 2001), 12.

${ }^{35}$ Kathryn J. Cooper, "Nineteenth-Century Cardiganshire: Its Economy and Society," in Exodus from Cardiganshire: Rural-Urban Migration in Victorian Britain (Cardiff: University of Wales Press, 2011 ), 21.

${ }^{36}$ D. C. Cox, et al, A History of the County of Shropshire, vol. 4, Agriculture, ed. G. C. Baugh and C. R. Elrington (London: Victoria County History, 1989), British History Online, accessed 22 March 2018, http://www.british-history.ac.uk/vch/salop/vol4.

${ }^{37}$ Gough, as Hey points out, discusses these at length. Gough, 266; Hey, An English Rural Community, 58.
} 
characteristically marked by great disparities in economic status, something that was in fact true of north Shropshire more widely. ${ }^{38}$ On the whole, there was a general lack of substantial holders, with farmers generally owning a wide-variety of livestock, rather than specializing in beef or dairy on a large scale. ${ }^{39}$

Owing to the economic importance of livestock rearing in Shropshire generally, open fields were neither as common nor as important as in communities where mixed farming was more widespread. ${ }^{40}$ In fact, a good deal of agricultural land brought into cultivation during the sixteenth century had been converted from woodland, not open fields. ${ }^{41}$ The process of enclosure in pastoral areas in general tended to be more gradual and its repercussions less muted than in the Midlands and other areas of the country. ${ }^{42}$ But, this does not mean enclosure was without consequences: one of its effects in Shropshire was reduced access to grazing lands. ${ }^{43}$ In Shropshire, the enclosure of open fields began prior to the mid-sixteenth century and occurred with enough frequency throughout the next two hundred years that by the mid-eighteenth century, open-field farming had effectively ceased within the county. ${ }^{44}$ Still, on the whole and as compared to other regions of England, Shropshire was enclosed relatively early and by private agreement. $^{45}$ Myddle fits this basic model of relatively prompt and harmonious enclosure, openfield cultivation having largely terminated in the parish by the late sixteenth century. ${ }^{46}$

\footnotetext{
${ }^{38} \mathrm{Hey}$, An English Rural Community, 52.

${ }^{39} \mathrm{Hey}$, An English Rural Community, 67.

${ }^{40} \mathrm{Cox}$, et al.

${ }^{41} \mathrm{Cox}$, et al.

${ }^{42} \mathrm{Hey}$, An English Rural Community, 9; Cox, et al.

${ }^{43} \mathrm{Cox}$, et al.

${ }^{44} \mathrm{Cox}$, et al.

${ }^{45} \mathrm{Hey}$, An English Rural Community, 9; Cox, et al.

${ }^{46} \mathrm{Hey}$, An English Rural Community, 29.
} 
At the same time as Myddle was spared some of the more harmful effects of enclosure, its social structure was also for the most part characterized by a lack of economic inequality. Even though there were several elite families who held land and resided within the parish, for various reasons, they were never capable of dominating Myddle's parish affairs. ${ }^{47}$ The population of laborers would increase during the late sixteenth century in Myddle, and the social makeup of the parish from 1631 to 1660 comprised 8 gentlemen (6.4 per cent), 22 yeomen (17.6 per cent), 30 husbandmen (24 per cent), 39 laborers (31.2 per cent), 18 craftsmen (14.4 per cent), and 8 others (6.4 per cent). ${ }^{48}$ In his history of Myddle, Gough treats landholdings according to worth and size and are divided into farms, tenements, and cottages. ${ }^{49}$ Although there was a manor at Myddle, there was no "resident lord," and the Downtons of Alderton Hall, the Gittinses of Castle Farm, and the Kinastons of Shotton made up the only three armigerous families in Myddle. ${ }^{50}$ Two families residing at Marton, the Hanmers and Atcherleys, were cadet branches of titled families whose principal residences were outside the parish, and Sleap Hall, held by the absentee Maynwarings, a noble family from Cheshire, was rented out to tenants. ${ }^{51}$ Additionally, the Chambres, Corbetts, Onslows, and Thornses, all gentry families, owned land in Myddle but were neither resident there nor very involved in the community or parish matters. ${ }^{52}$

During the seventeenth century, there were eleven farms within the parish of Myddle. ${ }^{53}$

The largest landowners in the parish were the Gittinses, who owned Eagle and Castle Farms (650

\footnotetext{
${ }^{47}$ Hey, An English Rural Community, 52-53.

${ }^{48}$ These calculations are from Hey's reconstruction of Myddle's occupational structure, which were determined using Myddle's parish registers. Hey, An English Rural Community, 53.

${ }^{49}$ Hey, An English Rural Community, 4.

${ }^{50} \mathrm{Hey}$, An English Rural Community, 52, 85.

${ }^{51}$ Hey, An English Rural Community, 52, 85.

${ }^{52} \mathrm{Hey}$, An English Rural Community, 52.

${ }^{53} \mathrm{Hey}$, An English Rural Community, 120.
} 
acres); the owners of Balderton Hall, Broomhurst Farm, and other properties (500 acres); and the Atcherleys, the leading family in Myddle, who resided in Marton (470 acres). ${ }^{54}$ Other sizeable properties in the parish were about half the size of the above estates: for example, the largest of these, owned by the Hanmers of Marton was only about 268 acres. ${ }^{55}$ Additional farms, smaller than the above but larger than the parish's tenements were Alderton Hall, owned by the Downton family; and Bilmarsh Farm, Hollins Farm, and Webscott Farm, which were associated with various tenants. $^{56}$

There were 48 tenements and half-tenements in Myddle, the acreages of which appear to have been quite variable, which Hey supposes might well reflect the fact that some of them comprised substandard land. ${ }^{57}$ Tenement residents tended to be husbandmen, yeomen farmers, and sometimes craftsmen, who supported themselves through pastoral farming. ${ }^{58}$ Long-term tenement-farming families in Myddle included the Goughs, Lloyds, Haywards, Braynes, Formston, and Tylers. ${ }^{59}$

Of the craftsmen, some held small-holdings, whereas others occupied larger tenements, since family dynamics were such that, due to relation and intermarriage, craftsmen were sometimes not identifiable as a separate class from some of Myddle's better-off tenementfarmers. ${ }^{60}$ Several families were associated with certain trades, such as the Chaloners, who labored as coopers and blacksmiths; the Davieses and Parkeses who worked as weavers; the

\footnotetext{
${ }^{54} \mathrm{Hey}$, An English Rural Community, 85, 97.

${ }^{55} \mathrm{Hey}$, An English Rural Community, 85.

${ }^{56} \mathrm{Hey}$, An English Rural Community, 107-18.

${ }^{57} \mathrm{Hey}$, An English Rural Community, 119-20.

${ }^{58} \mathrm{Hey}$, An English Rural Community, 119.

${ }^{59} \mathrm{Hey}$, An English Rural Community, 126-35.

${ }^{60} \mathrm{Hey}$, An English Rural Community, 143.
} 
Hordleys and Taylors who traded as tailors; and the Raphes and Wagges who were carpenters. ${ }^{61}$ Craftsmen in the parish from 1631 to 1660 included one blacksmith, one carpenter, one cooper, one glover, one mason, one shoemaker, six tailors, and six weavers. ${ }^{62}$

Though Gough fills in some of the gaps concerning the parish's laborers, they were the social group that tended to escape documentation the most frequently, as a result of their lower social status and mobility. ${ }^{63}$ These individuals, fortunate to have lived in an area of pastoral farming that was inclined to provide year-round, regular work, would have made their living through agricultural labor - digging ditches, sowing seeds, weeding fields, and harvesting produce - and have supplemented this with small-holding. ${ }^{64}$ As with the parish craftsmen, there was a degree of fluidity between social classes. Owing to the blurring of social classes that tended to occur across families - where one son might have been regarded as a tenement-farmer while another considered a laborer - and social mobility across time, it is difficult to isolate family names associated with laboring families. Nevertheless, laborer surnames in the seventeenth century included long-standing resident families of Chidlow, Clarke, Fardo, Hanmer, and Shaw, as well as newcomers Crompt, Harries, Mitton, Pickering, and Preece/Price. ${ }^{65}$

Even though social stratification increased in the late seventeenth century, for the most part Myddle "still had few of the very rich, but also relatively few of the very poor." ${ }^{66}$ Yet, there

\footnotetext{
${ }^{61}$ Hey, An English Rural Community, 143.

${ }^{62}$ Hey, An English Rural Community, 53-54.

${ }^{63} \mathrm{Hey}$, An English Rural Community, 162, 169.

${ }^{64} \mathrm{Hey}$, An English Rural Community, 165. On the features of pastoral labor economies, see John Mathieu, History of the Alps, 1500-1900: Environment, Development, and Society, trans. Matthew Vester (Morgantown, West Virginia: West Virginia University Press, 2009), 210-11.

${ }^{65} \mathrm{Hey}$, An English Rural Community, 173.

${ }^{66} \mathrm{Hey}$, An English Rural Community, 55.
} 
are a few important qualifications to Myddle's mostly uniform social structure. First, despite the lack of excessive variabilities in wealth, and Myddle's classification as largely having been made up by the middling sort, Gough's writings do show great concern over the poor, which is instructive about the anxieties that appear to have plagued the gatekeepers of community order in this period. Second, Myddle, though appearing relatively uniform, was not timeless. Myddle by the mid-1800s had evolved from a relatively equal society, characterized by a pastoral economy and small tenement farmers, to an arable economy and a community largely divided between wealthy farmers and laborers, in which there was a greater disparity of wealth. ${ }^{67}$ In its focus on poor law administration, this study attempts to examine aspects of this transition.

\section{Richard Gough (1635-1723)}

Richard Gough's own family history was characterized by a residence in Myddle that covered over a century and a half. This plainly influences his approach to The History of Myddle, for in writing his local history Gough seeks order and permanence as his two guiding principles. Moreover, Gough writes firmly entrenched in this proper world of middle-class decency and envisions the community of Myddle as it is informed by his own social standing. Both his family's status and the anomaly of its permanence in Myddle allowed Gough to write his account of Myddle, since without these advantages he would have been less well-poised to comment upon the history both of Myddle itself and its various families. In short, the Goughs existed, as it were, as an island of stability surrounded by an ocean of "the restless mobility of rural existence." 68

As Gough catalogues within the pages of his local history, his family's history in Myddle dated back to the early sixteenth century, when Richard Gough I came to reside at Newton on the

\footnotetext{
${ }^{67}$ Hey, An English Rural Community, 4, 230-31.

${ }^{68}$ Henry French, 77.
} 
Hill in 1539 from nearby Tilley. ${ }^{69}$ Despite his somewhat lengthy treatment of Gough family history, somewhat oddly, Gough does not write much about his own parents. He records that his father, also named Richard Gough, married Dorothy Jenks, the daughter of Richard Jenks of Cockshutt and Crosemere and Elizabeth Groome. Gough mentions that his father purchased land from Sir Richard Lea and that his father-in-law was a tenant of Sleap Hall and held a lease of freehold lands at Sleap Town. He also writes that physically his father was of "middle stature," but "very active of body, and of a nimble strength." ${ }^{70}$ A later Gough family history records that Gough's father died at Cayhowell in 1661, and is buried at St. Mary's Church in Kinnerley. ${ }^{71}$ Perhaps unusually, Gough's parents only had two children: Gough himself and his younger sister Dorothy, who was baptized at Myddle on 1 October 1637 and who was still living at the time Gough was compiling his history around $1701 .^{72}$ Dorothy Gough's first husband was Andrew Bradocke of Cayhowell, and after his death in April 1662 she married Richard Glover of Measbury. ${ }^{73}$

Richard Gough was baptized in Myddle on 18 January 1634/5. ${ }^{74}$ As a young man, he was educated at Myddle by Richard Roderick and next by Reverend William Sugar, the minister

\footnotetext{
${ }^{69}$ F. H. and A. V. Gough, authors of an addendum to Richard Gough's 1701 account of the family, offer some corrections to portions of Gough's own family tree. Principally, they point out that Gough considered Richard Gough I and Richard II as separate figures when they were likely the same individual. Another point of confusion appears in that there is some disagreement as to the name of Richard Gough III's wives: Gough lists his first wife's name as Elizabeth Crump, while Gough and Gough give her Christian name instead as Joan, citing three 1575 entries in the Shawbury parish registers. Gough then identifies his second wife as Anne [--?--], while Gough and Gough, along with Myddle's parish register, record her name as having been Gwen [--?--]. W. P. W. Phillimore, ed., Registers of Myddle, Shropshire Parish Registers, Lichfield Diocese, vol. 19 ([Shropshire]: Shropshire Parish Register Society, 1931), 39, 51; Gough, 153-57; F. H. Gough and A. V. Gough, "The Goughs of Myddle and Their Descendants," in Transactions of the Shropshire Archaeological and Natural History Society, 2nd ser., vol. 5, part II (Oswestry: Woodall, Minshall, and Co., 1893), 261-66.

${ }^{70}$ Gough, 169.

${ }^{71}$ Gough and Gough, 272.

${ }^{72}$ Registers of Myddle, 95

${ }^{73}$ Gough, 169; Gough and Gough, 272-73.

${ }^{74}$ Registers of Myddle, 91.
} 
of Broughton. ${ }^{75}$ Through the course of his education, Gough was educated in Latin and developed a love of the classics, something that can be seen in his frequent use of classical proverbs throughout The History of Myddle. Both F. H. and A. V. Gough and E. M. W. Rogers report that during the English Civil War, as a young boy aged around twelve or thirteen years old, Gough witnessed a small skirmish and that he tended to hold royalist sympathies. ${ }^{76}$ Though it seems that Gough did not travel widely, he does mention a visit to London made while he was a young man. ${ }^{77}$

Later in life, Gough worked as a servant in the household of Robert Corbett of Stanwardine, in the parish of Baschurch, a period in his life that Gough seems to recall fondly, as he praises the education he received there and writes of his high esteem for the gentry Corbett family. ${ }^{78}$ The time he spent in the Corbett household is also when Gough reportedly gained his training in law. ${ }^{79}$ After leaving this position, it appears that Gough served as steward at the manors of Albright Hussey and Battlefield, other Corbett family holdings, for around twenty years. ${ }^{80}$ Gough inherited property at Newton on the Hill, within Myddle, in 1660, at the age of twenty-six, and probably as a result of his becoming a man with some means, married at around the same time. ${ }^{81}$ He married Joan Wood, the daughter of William Wood of Peplow and Joyce Baddeley. The couple had a fairly large family, eight children in all, including two sons who

\footnotetext{
${ }^{75}$ Gough and Gough, 274; E. M. W. Rogers, A Short History of the Church and Parish of St. Peter's, Myddle, Shropshire (Myddle, Shropshire: Church of St. Peter's, 1984), 4.

${ }^{76}$ Gough and Gough, 274; Rogers, 4.

${ }^{77}$ Gough and Gough, 274.

${ }^{78}$ Gough, 131.

${ }^{79}$ Rogers, 4.

${ }^{80}$ Gough and Gough, 274; Rogers, 4.

${ }^{81}$ Rogers, 4.
} 
died in infancy. ${ }^{82}$ Gough's household appears on the 1672 Shropshire hearth tax as residing within the parish of Myddle at Newton on the Hill. ${ }^{83}$

Gough seems to have been an orthodox Anglican, who, while expressing both antiCatholic sentiments and disapproval of Protestant religious extremism, had a number of friends and relations who had been Parliamentarians during the Civil War, including his patron, Robert Corbett. $^{84}$ As a man of the community, Gough served on Shropshire's grand jury and as churchwarden for the parish of Myddle in 1662. He was generally active in parish affairs, and was a trustee of the apprenticeship charity set up by his uncle, William Gough, who was from nearby Sweeney. Gough also mentions his personal involvement in a few of the parish settlement cases he details in the latter pages of The History of Myddle, such as the seventh case involving Nicholas Hampton of Wem. (Hampton's settlement case comprises part of those addressed more completely in chapter three.) It should be noted that Gough's general standing in the community as well as his service as churchwarden most likely influenced his contributions to these cases, and he was almost certainly concerned about the parish's resources being stretched too far in the support of those regarded as idle paupers. All in all, it appears that Gough was a well-respected individual in the community, and a dedication in his honor was inscribed on the tenor bell of St. Peter's, the parish church of Myddle, in $1668 .^{85}$

\footnotetext{
${ }^{82}$ Gough, 169-70.

${ }^{83}$ Gough's residence contained two hearths, which were assessed at 4s. Except for Richard Jukes, who was assessed at the same rate as Gough, the remaining dwellings had one hearth each, giving Newton on the Hill a grand total of eleven hearths. Myddle itself, by comparison, contained the much larger number of fifty-four. Shropshire Archaeological and Parish Register Society, The Shropshire Hearth Tax Roll of 1672: Being a List of the Householders in the County (Shrewsbury, Shropshire: n.p., 1949), 191, 205, Family History Library (FHL) microfilm 453,027, item 1 (FHL, Salt Lake City, Utah).

${ }^{84}$ Hey, "Introduction," The History of Myddle, 17.

${ }^{85}$ The inscription reads: "Caeteros voco ipse non intro [I call others to enter, and not myself] ... ." Gough and Gough, 274; Rogers, 4.
} 
Gough's wife died in 1694, with Gough recording that she died at his house in Newton and "lyes burried in Myddle Chancell." ${ }^{86}$ This was not the only sadness that Gough experienced by the time that he began compiling his history of Myddle, for his eldest son, Richard Gough VII, a young man of around twenty-six years of age, had also died in 1689, just five years before his wife's passing. ${ }^{87}$ His son Baddeley died of smallpox in the nearby town of Shrewsbury in $1691{ }^{88}$ It also appears that Gough's son William died between 1701 and 1722, in the period directly following Gough's writing of The History of Myddle, for William does not appear in his father's will. $^{89}$ In fact, save for his daughters Joyce, Anne, and Dorothy, the rest of Gough's children, and all of his sons, had predeceased him. In the end, only his daughter Anne married, and her children were Gough's sole heirs. ${ }^{90}$ Gough himself died in Myddle on 9 February 1722/3 and was buried a few days later on 12 February. ${ }^{91}$

\section{The History of Myddle}

Richard Gough composed The History of Myddle around 1700-1701, though it was not published until 1834 by Sir Thomas Phillips, incompletely, as the "Antiquityes and Memoyres of the Parish of Myddle," while a more faithful printing was made in 1875 by Messrs. Adnitt and Naunton of Shrewsbury. This second printing, that most often cited and the version considered here, contains proofs that were checked against the original manuscript by Prebendary Egerton,

\footnotetext{
${ }^{86}$ Gough, 169; Registers of Myddle, 116.

${ }^{87}$ It appears that the parish register entries for the years 1645 to 1681 are non-extant, but Gough and Gough give Richard Gough VII's birth year as 1663 . Though no source is cited for this information, they indicate that he died "d.s,p.," that is, descessit sine prole, or "leaving no heirs." Moreover, Gough recounts in The History of Myddle that he purchased land of the indebted Richard Jukes II, intending it for his eldest son, "butt it pleased God that hee dyed, and my two other sons were both sett apprentices, and therefore, I sold the house, and some part of the land to Edward Garland ..." Gough, 99; Gough and Gough, 274; Registers of Myddle, 109.

${ }^{88}$ This child was actually the second of Gough's children to be named as such, the first having died earlier, less than a year old, in 1669. Gough and Gough, 275.

${ }^{89}$ Gough and Gough 275.

${ }^{90}$ Rogers, 4.

${ }^{91}$ Registers of Myddle, 158.
} 
then rector of Myddle, with title page illustrations, church plans, and spellings preserved as in Gough's original manuscript. The manuscript itself is presently held by the Shropshire Archives in Shrewsbury. According to Hey, it was rebound between 1800 and 1802 and more recent conservation notes indicate that due to deterioration, the manuscript was sent to the National Library of Wales where it was both reinforced and rebound. ${ }^{92}$

Gough's writings eventually came into the possession of the Bickerton family and seem to have existed in relative obscurity until they were discussed in several radio broadcasts by a Mrs. Veronica Bamfield during the winters of 1962 through $1965 .^{93}$ At the same time came an increasing concentration on social history, inspired by E. P. Thompson's influential concept of "history from below," and interest in the work was accordingly ignited around this time. In his Local History in England, W. G. Hoskins recounts that he came across Gough's work "in a little bookshop just outside Waterloo Station during the war," which led to the work's rediscovery by modern scholars. ${ }^{94}$ In fact, Hoskins himself reprinted the work in 1968, as did David G. Hey more recently, in $1981 .^{95}$

As unique as The History of Myddle seems at first glance, Gough appears to have been writing in a tradition of local history that was popular in this period. The work shows the influence of works others such as William Camden's Britannia, a well-known topographical and historical account of the history of the British Isles that first appeared in Latin in $1586 .{ }^{96}$ Gough

\footnotetext{
${ }^{92}$ Richard Gough, Antiquities and Memoyres of the Parish of Myddle (original manuscript), 1700, 1525/1 (Shropshire Archives, Shrewsbury); Hey, "Introduction," The History of Myddle, 25-26; Gough and Gough, 273; Rogers, 3-4.

${ }^{93}$ Gough and Gough, 273; Rogers, 3.

${ }^{94}$ W. G. Hoskins, Local History in England (London: Longmans, Green and Co. Ltd., 1965), 22.

${ }^{95}$ Hey's volume is that cited herein, while Hoskins's version was published as Richard Gough, The History of Myddle, with an introduction by W. G. Hoskins (Fontwell, Sussex: Centaur Press, 1968).

${ }^{96}$ Gough in fact cites Camden's authority several times, particularly in his account of Myddle's early history. Camden, adopting "Industrie" as his companion, famously articulated that his main aim was to "restore antiquity to
} 
also seems to have been influenced by travel writers such as William Dugdale, who wrote a parochially-based county history of Warwickshire in $1656 .^{97}$ Gough's history is also similar to White Kennett's Parochial Antiquities Attempted in the History of Ambrosden, Burcester and Other Adjacent Parts, an Oxfordshire parochial history originally published in $1695 .^{98}$ Though both works are primarily parish histories, Kennett's chronicle is much more comprehensive in scope than Gough's, beginning as it does in Britain's pre-Roman past. ${ }^{99}$ Each also contains a glossary of ambiguous historical terms. ${ }^{100}$ Gough was conceivably catering to the same general antiquarian-minded readership of works like Camden's and Kennett's although it is unclear whether he ever intended The History of Myddle for publication. ${ }^{101}$

Gough did, however, intend the work to be read. Like most of such local history and genealogical works, The History of Myddle was also probably intended for some of Myddle's own families, particularly its educated and well-connected longstanding residents, as the work's primary audience. This is revealed by the text's basic narrative structure. Despite the fact that the first part of the text, entitled "Antiquityes and Memoyres of the Parish of Myddle" (the part published by Phillipps in 1834) is similar to some of the above-mentioned roughly contemporaneous local histories, the second part entitled "Observations Concerning the Seates in Myddle and the Familyes to Which They Belong" is much more singular. ${ }^{102}$ Thus, at the same

Britaine, and Britain to its antiquity." Gough, 49, 54, 70, 88; William Camden, Britannia, vol. 1, translated by Philemon Holland (London: 1610), xxxi.

${ }^{97}$ William Dugdale, The Antiquities of Warwickshire Illustrated: From Records, Leiger-Books, Manuscripts, Charters, Evidences, Tombes, and Armes, Beatified with Maps, Prospects, and Portraictures (London, 1656).

${ }^{98}$ Hoskins, Local History in England, 21-22.

${ }^{99}$ White Kennett, Parochial Antiquities Attempted in the History of Ambrosden, Burcester, and Other Adjacent Parts in the Counties of Oxford and Bucks, vol. I (Oxford: 1818).

${ }^{100}$ Mayer, 66-67.

${ }^{101}$ Hey, "Introduction," The History of Myddle, 25.

${ }^{102}$ Mayer, 67; Rogers, 4. 
time as Gough mirrors wider trends, through his distinctive choice to arrange his narrative around the parish church seating plan, he also gives voice to the very local world of Myddle. As Henry French points out, one major critique of The History of Myddle is that Gough's own prejudices create a false impression of stability in Myddle, and the work communicates an air of changelessness because the families that make up the bulk of The History of Myddle owe their presence primarily to "the accident of longevity." ${ }^{103}$ Gough's narrative is therefore selective, through both the above practical decisions regarding which families to include in his history as well as his own ethical and moral preoccupations.

Illustrative of this is the suggestion that one of the primary purposes behind the compiling of The History of Myddle was legal and referential, in that it is first and foremost a catalogue of pew ownership. ${ }^{104}$ Gough's motives in writing his local history are not immediately clear, and Hey points out that although Gough would live many years after completion of The History of Myddle, he produced no other works. ${ }^{105}$ In the absence of other evidence revealing his purposes, Gough's most straightforward objective was specifying pew ownership, and taking that claim a bit further, perhaps putting forward a set of claims that would comment on any future pew ownership disputes. ${ }^{106}$ In its relation to pew seats, by implication, the work is also a record of land tenure. Moreover, because they did not hold seats in the parish church at Myddle, residents who attended the chapelry at Hadnall are not discussed and only inhabitants of Myddle itself are included. ${ }^{107}$ Gough cautions at the outset that his readers must remember that pew ownership is

\footnotetext{
${ }^{103}$ Henry French., 80.

${ }^{104}$ Hey, "Introduction," The History of Myddle, 9; Henry French, 75.

${ }^{105}$ Hey, "Introduction," The History of Myddle, 8.

${ }^{106}$ Hey, "Introduction," The History of Myddle, 9.

${ }^{107}$ A chapelry was an ancillary place of worship and as such Hadnall served as a subdivision within the parish of Myddle. In his introduction to the printed parish registers of Myddle, W. G. D. Fletcher writes about this issue that "[t]he inhabitants of Hadnall had anciently to pay one-fourth of every levy for repairing Myddle Church,
} 
not inherited and is connected to land ownership. However, because his narrative primarily focuses on property, this means that Gough indirectly concentrates on landowning families. Gough writes: "A peiw or seat does not beelong to a person or to land, butt to an house, therefore if a man remove from an house to dwell in another, hee shall not retain the seat belonging to the first house ..." 108 In fact, Gough tells of the censuring of Thomas Highway for attempting to rent out his seat by payment of a yearly fee to another cottager. Of this, Gough tells that this was judged as unethical and Highway was in turn "blamed for doeing wrong to the Parish," which reflected a violation of the custom that it was typically the parish that benefitted financially from such arrangements. ${ }^{109}$

In the wider scheme, Gough's decision to organize his study around the parish church pews, on the face of it a somewhat unconventional choice, can be seen as representative of a spatial emphasis on family and lineage in the post-Reformation period within the parish church. Beginning in the fifteenth century, churches began to gradually shift over to pew seating, so that the practice was much more common in the latter part of the century. In contrast to the gendered seating plan of the medieval parish church, after the Reformation, pews and seats began to be bought and sold as a way of raising money within the parish. ${ }^{110}$ The selling of pews meant that

and yet they had no seats allotted to them at Myddle, and no allowance given them towards the maintenance of the curate of Hadnall; and this caused a good deal of controversy between the authorities of Myddle and Hadnall." Again, it is apparent that contention marked the community. W. G. D. Fletcher, "Myddle Registers," in Registers of Myddle, Shropshire Parish Registers, Lichfield Diocese, vol. 19, ed. W. P. W. Phillimore ([Shropshire]: Shropshire Parish Register Society, 1931), vii.

${ }^{108}$ Gough, 77.

${ }^{109}$ Gough, 183.

${ }^{110}$ This phenomenon seems to have mostly occurred in urban parishes and market towns and to have been less common in rural parishes. There is also some indication that the renting of pew seats became a source of money for a parish at the same time as medieval sources of income - like church ales - were no longer utilized. Robert Tittler, "Seats of Honor, Seats of Power: The Symbolism of Public Seating in the English Urban Community, c. 1560-1620," Albion 24, no. 2 (Summer 1992): 218; Christopher Marsh, "Order and Place in England, 1580-1640: The View from the Pew," Journal of British Studies 44, no. 1 (January 2005): 8; Katherine French, The Good Women of the Parish: Gender and Religion after the Black Death (Philadelphia: University of Pennsylvania Press, 2008), 100. 
the well-to-do bought the best seats, usually toward the front of the church, while those with less money generally bought seats further back. The practice affected women and the poor most severely. It affected the former because instead of sitting communally with other female members of the community, they now sat with their families, which played into a burgeoning emphasis on the nuclear family. ${ }^{111}$ Women, understandably, were also infrequently the ones purchasing seats, and the poor of course could not afford to buy seats at all. The fact that families now sat together in pews in permanent seats also meant that there was a growing sense of a family's lineage and place within the parish. For example, pews were sometimes decoratively carved, and displayed family crests or tools symbolic of the family's trade. ${ }^{112}$ Family burial plots also began to be utilized in this period. ${ }^{113}$

Some parishes, like Myddle, did not sell pew seats. Instead, particular seats had over time become "customarily linked" to certain dwelling places. ${ }^{114}$ This connection between pew ownership and property admittedly means that Gough often discusses tenants in addition to property owners. Nevertheless, he also reveals that there was a strict hierarchy in Myddle. This is epitomized in the structure of Gough's narrative, proceeding as it does pew by pew, from the first pew of the north side of the north aisle around the parish church, an arrangement that was a reflection of social organization within a community. Within the parish church it was the gentry who typically sat up front, both closer to the priest and from where they could be seen by the rest

\footnotetext{
${ }^{111}$ Katherine French treats this particular development more specifically in The Good Women of the Parish: Gender and Religion after the Black Death, a study that outlines women's collective participation in parish life in the post-Black death and pre-Reformation period. French's thesis in this work is that after the Reformation, women's group participation gave way to a more internalized role within the familial household. Katherine French, The Good Women of the Parish, 94-117.

${ }^{112}$ Katherine French, The People of the Parish: Community Life in a Late Medieval English Diocese (Philadelphia: University of Pennsylvania Press, 2001), 163.

${ }^{113}$ John Bossy, Christianity in the West, 1400-1700 (New York: Oxford University Press, 1985), 33, 142.

${ }^{114}$ Marsh, 8 .
} 
of the congregation; craftsmen and farmers roughly in the middle; and cottagers in the back. ${ }^{115}$ In essence, Gough thus moves from the well-to-do, down as he discusses each row of pews in turn and even details a further pecking order existing within the pews themselves, noting that when a landowner, as opposed to a mere tenant, attended worship service, the seating chart changed accordingly. For example, when discussing a particular pew attached to the property of Sleap Hall, Gough writes that when Mr. Maynwaring, the property owner, was in residence, "hee sate uppermost in this seat; but when tenants are there Mr. Acherley sits above them." ${ }^{116}$ Above all, social standing in Myddle revolved around land, for land tenure and position within the parish church were wholly intertwined. ${ }^{117}$ In addition, Gough's decision to make land, by way of the pews of the parish church, the organizational heart of his survey means that any detailed treatment of Myddle's lower classes is hindered, for this was a group of people whose place was at the very back of the parish church and for whom the connection with property was much more tenuous. ${ }^{118}$ This is one of the fundamental ways in which the narrative structure of The History of Myddle informs how Gough treats the poorer families of Myddle.

However, this is not to say that Gough treats Myddle's prosperous class evenhandedly either. For instance, within his various family histories certain groups - most distinctly younger sons and daughters - are also omitted from full consideration. Because the eldest male child usually inherited his father's property upon his demise, there is a tendency to treat surviving male heirs in a more complete manner than the other male children in a family, even if Gough does

\footnotetext{
${ }^{115}$ Rogers, 4.

${ }^{116}$ Gough, 92 .

${ }^{117}$ Mayer, 65.

${ }^{118}$ Geremek for instance highlights this major difficulty inherent in studying marginal groups due to the poor's general mobility, writing that nomadism was their frequent condition. Bronisław Geremek, The Margins of Society in Late Medieval Paris, trans. Jean Birrell (New York: Cambridge University Press, 1987), 7.
} 
customarily discuss the male heir last. ${ }^{119}$ In the case of the respectable tenement-farming Lloyd family, whom Gough dubs as possibly "the antientist famyly in this part of the parish," such partiality can clearly be seen. ${ }^{120}$ While Thomas Lloyd of Emstrey had three children, two sons and a daughter, and the marriage of the eldest son Richard is noted, because Richard had no issue, his younger brother Thomas receives the bulk of the attention. ${ }^{121}$ Even more pronounced is Gough's treatment of the Atcherley family of Stanwardine, a dominant family in Myddle. Although Gough begins with Richard Atcherley, whom he notes was a younger son, he finds him worthy of mention because of his purchase of lands in Marton and Twiford. Only one of Richard's children is mentioned: Thomas, who inherited his father's property in Marton. Thomas in turn had two sons and two daughters, but save for his eldest son, also named Thomas Atcherley, the names of their spouses are merely given and only Thomas's descendants are traced. ${ }^{122}$ In fact, children are usually listed in the customary pattern of sons followed by daughters, thus obscuring natural birth order, which would have inevitably occurred in a more mixed fashion.

As would be expected, Gough provides fewer particulars about wives and daughters. Instances abound, but as in the example of Thomas Atcherley I mentioned above, only Thomas's elder daughter is even named, and Gough simply records that his youngest daughter married "one Simcocks, a mercer in Whitchurch." ${ }^{123}$ Additionally, it appears that Gough includes more details regarding Thomas's elder daughter Mary's marriage to Roger Griffiths simply because his

${ }^{119}$ Gough, 97; Henry French, 78-79.

${ }^{120}$ Gough, 95 .

${ }^{121}$ Gough, 95.

${ }^{122}$ Similarly, Gough does mention that Richard Atcherley's son Thomas did marry a second time after the death of his first unnamed wife. It is not mentioned whether he and his second wife, the wealthy widow of Nicholas Gough of Wolverley, had any children. Gough, 89-90.

${ }^{123}$ Gough, 89. 
sister Elinor married Thomas's eldest son and heir Thomas Atcherley II. ${ }^{124}$ When Gough refers to marriages, he sometimes names brides, but whether he identifies the women by name, he inevitably mentions their fathers, often in connection with their property or residence. Gough writes that the wife of Edward Clive was the daughter of Richard Lloyd of Cayhowell. Despite the fact that she was Lloyd's heiress, she remains nameless. ${ }^{125}$ Conventions like these reveal a gendered treatment of Myddle's family history in which much more space is devoted to the eldest male in a family, followed by younger sons and then daughters, about whom the fewest details are generally included. In this sense, Gough's study reflects the patriarchal organization of English society at the time via the microcosm of the parish. Moreover, preoccupied with matters of inheritance, such standards also reveal how Gough's concerns with land and property ownership lead him toward an uneven treatment of both class and gender.

\section{Morality in Myddle}

The above attitudes inform other parts of Richard Gough's narrative, in that property serves as a way to both conceive of the community and organize its population. Yet, Gough has another axis of organization that is moral in nature. This overlays his focus on property ownership and adds another element to The History of Myddle. Gough, in gossipy tones, is quite vocal about those individuals he regards as morally respectable and those whom he does not. Gough singles out several qualities for special praise, such as office holding and involvement in the parish community, as well as charity to the poor. He also commends skillfulness, industriousness, hospitality, prudence, and even-temperedness, qualities that transcend his emphasis on property and class.

\footnotetext{
${ }^{124}$ Gough, 89 .

${ }^{125}$ Gough, 85, 86.
} 
Local officeholders whom Gough commends include Thomas Atcherley II, who distinguished himself by having served "many offices with much care and faithfullnesse," three times as High Constable for the Hundred of Pimhill, and "often" as a churchwarden in Myddle. ${ }^{126}$ Likewise, Gough praises former churchwarden Thomas Jukes II, as "a good ingeniouse person, well skilled in many country afaires." ${ }^{127}$ Richard Groome was similarly lauded for his service to the parish for his "faithfullnesse, diligence, and paines, as well in this as in severall other matters for the parish." ${ }^{128}$ Gough also writes that William Cleaton of Hollins Farm "lived in good repute" and served "severall offices" in the parish of Myddle, although he does not note which particular positions Cleaton held. ${ }^{129}$

Moreover, in terms of landed individuals Gough marks out the Robert Corbett for whom Gough himself had worked as a clerk in his youth, for especial praise: Corbett "was a very eminent person in this county" who had served as Justice of the Peace, Keeper of the Rolls for the County of Shropshire, a Master in Chancery, as well as an MP. ${ }^{130}$ Gough apparently held much fondness for Corbett, subsequently pronouncing the Corbetts of Stanwardine in the Wood "a worthy family" before again noting that he had served under Richard Corbett for several years, which resulted in him receiving the "best education." ${ }^{131}$ Another member of the Corbett family who seems to have had standing outside of Myddle is Sir Vincent Corbett of Moreton Corbett. After mentioning Corbett as the named guardian for Dorothy and Jane Kinaston

\footnotetext{
${ }^{126}$ Gough, 90.

${ }^{127}$ Though what these somewhat ill-defined "country afaires" are the reader is left to puzzle. Gough, 97.

${ }^{128}$ Gough, 289.

${ }^{129}$ It must be said, however, that William Cleaton's respectable standing did not prevent Gough from judging Cleaton's son Richard an immoral and general "untowardly person." Gough, 92.

${ }^{130}$ Gough, 86.

${ }^{131}$ Gough, 131.
} 
following their father Phillip Kinaston's death, Gough notes that Corbett was considered "a very eminent person in this county." ${ }^{132}$

Although the poor themselves seem to be considered a different matter, Gough appears to consider charity to Myddle's poor admirable and seems to mention such behavior when aware of it. For example, he singles out Thomas Atcherley II for praise for bequeathing $24 \mathrm{~s}$ per year to the poor of Myddle, as well as his wife Elinor, who left $£ 10$, the interest of which was to be given to the poor yearly at All Saint's Day. ${ }^{133}$ Thomas Lloyd, of the above-mentioned "ancient" Lloyd family of Myddle, similarly bequeathed $£ 5$ to the poor of the parish, with the interest to be annually distributed on St. Thomas's Day. ${ }^{134}$ Despite the otherwise poor decision of Gough's uncle William Gough in giving most of his lands to his wife's relatives rather than to his own, he nevertheless managed to leave $£ 5$ per annum each to the parishes of Myddle and Oswestry for the setting up of apprenticeships, the former charity being that for which Gough himself would later act as a trustee. ${ }^{135}$ Additionally, William Gough allowed one noble per year to the minister of Oswestry to preach a sermon on St. Stephen's Day. ${ }^{136}$ Cook Richard Hayward likewise bequeathed $£ 10$ to the poor of Myddle with the interest to be given out monthly as bread. Gough reports that Hayward appointed twelve individuals to receive the distributions during his lifetime, and after his death indicated that the minister and churchwarden should see to its

\footnotetext{
${ }^{132}$ Corbett eventually married the Kinaston daughters to two of his own servants. Gough, 84-85.

${ }^{133}$ Gough, 90-91.

${ }^{134}$ Gough, 95 .

${ }^{135}$ Fletcher, along with William Gough's will, confirm this along with the other charitable bequests mentioned by Gough, noting that William Gough, gentleman of Sweeney, through his lands in Trevelach, supplied $£ 5$ annually for the setting up of apprenticeships for poor children in Myddle. Will of William Gough, Gentleman of Sweeney, Shropshire, 4 May 1669, PROB 11/329/509, Prerogative Court of Canterbury Wills, 1384-1858, The National Archives, Kew, Richmond, Surrey; Fletcher, x.

${ }^{136}$ Though here Gough gives the place name as "Oswaldtre," the reference refers to the nearby Shropshire parish of Oswestry. Will of William Gough, 4 May 1669; Gough, 167.
} 
dispersal. ${ }^{137}$ Though no specific bequests or deeds are mentioned, Gough writes that Thomas Baker, Jr. was both often charitable to the poor and very good to his servants, keeping his servants on until they married, and when they did so, often giving them additional remuneration. $^{138}$

Regarding creditable qualities that cut across the boundaries of class and landholding, Gough also frequently lauds those who are skillful. As well, it seems that those who are generous, prudent, and who helped their neighbors, thus strengthening the bonds of the community, are particularly praiseworthy. Bartholomew Mansell, for instance, who was a practiced butcher, "was very serviceable to his neighbours in dressing meate att feasts, and in slaughtering beeves and swine, all which hee did att a very reasonable rate." ${ }^{139}$ Correspondingly, James Jukes, a baker who lived in Wem, was apparently a very skillful cook who "had a courteouse, obliging carriage, and had great custome to his house." ${ }^{140}$ Gough likewise praises the good hospitality of the charitable Thomas Baker, Jr. but is careful to note that although Baker kept both a noble house and good hospitality, he was profligate and "[a]s hee increased in dignity, soe he decreased in riches." ${ }^{141}$ These examples, through their praising of neighborliness and negative view of greediness and wastefulness, are suggestive of the basic outlines of Myddle's moral economy and reflect those values that transcended social division.

In like manner, Gough repeatedly underscores the importance of moderation and selfrestraint regarding both money and personal behavior and admires wise yet cautious investments. Richard Muckleston, a tanner in Shrewsbury, for example, "was a provident man, a careful

\footnotetext{
${ }^{137}$ Gough, 278.

${ }^{138}$ Gough, 160.

${ }^{139}$ Gough, 152.

${ }^{140}$ Gough, 98 .

${ }^{141}$ Gough, 161.
} 
tradesman," but was resourceful enough to purchase "a great Estate in lands." ${ }^{142}$ Although the rungs of the property ladder could be prudently ascended, it seems no one was safe from a fall from grace. Gough for instance notes that the unnamed widow of Roger Langford, who had once "maintained the best Hospitality and good housekeeping of anyone in Myddle Parish" had been reduced to living "in a poore cottage in great poverty and want." ${ }^{143}$ She experienced such hardship after her marriage to the spendthrift Thomas Hodgkins, who "spent his Estate faster than his Ancestors gott itt ..." ${ }^{144}$ As he praises industriousness, so Gough tends to criticize those who were indolent, such as the lazy carpenter Richard Maddocks, who consequently had trouble finding work, and John George, whom Gough writes had no other moral failings save for one: idleness. ${ }^{145}$

Gough's ultimate view on respectability is perhaps hinted at in his remark about William Cooke from Cheshire, who had come to live at Sleap Hall "and lives there now, in good repute." ${ }^{146}$ To be sure, this was not a paradigm in which respectability was automatically conferred. It certainly was not the case for the reprehensible Michael Chambre, of whom Gough caustically says that "there was nothing commendable in him but that hee was well descended, and that hee was so blasted by his vitiouse life that hee was a person of noe accompt." ${ }^{147}$ For Gough, then, living in "good repute" appears to have been viewed as a present state typified by an active process. What this means is that although it secured one a respectable position that could be gained at least in part through hard work, this certainly did not render one totally

\footnotetext{
${ }^{142}$ Gough, 200.

${ }^{143}$ Gough, 192.

${ }^{144}$ Gough, 191.

${ }^{145}$ Gough, 151-52.

${ }^{146}$ Gough, 92 .

${ }^{147}$ Gough, 218.
} 
protected from an eventual falling off the wagon of propriety. Respectability had to be worked at, and must be maintained. Especially for those who came from families like the Goughs, decency was earned rather than given, "ancient" though a family may have been.

This makes it easy to see why Gough frequently praises those who were hard working, such as Griffith ap Reece, John Gough, and Thomas Freeman. ${ }^{148}$ Interestingly, these attributes were not only limited to skilled artisans, or indeed even the able-bodied: though Anne Parkes suffered from rickets and was unable to walk until she was nineteen years old, Gough praises her industriousness, writing that she nonetheless was able to support herself even after the death of her parents by knitting gloves and stockings. He also admires her setting aside of 20s even though she was likely "never worth more all her life" to pay for the cost of her funeral, concluding his account of Anne Parkes, by quoting Cato: "Of what use to you are riches, if you flourish in poverty?" ${ }^{149}$ Gough also gives special recognition to Anne's father William. Despite the fact that Parkes was but a poor weaver with eleven children, Gough finds it commendable that neither Parkes nor any of his children ever became chargeable to the parish for poor relief. Gough again emphasizes moderation and the avoidance of excess. In the William Parkes's case Gough recalls the words of Horace: "He to whom fate has given enough, should not wish for more." 150

Interestingly, Gough appears at times to equate moral goodness and bodily appearance. Gough singles out certain women of the parish as handsome and attractive and often mentions physical attractiveness and humility especially when writing of women, revealing that these two traits were the most important womanly attributes. For example, when discussing the two

\footnotetext{
${ }^{148}$ Gough, 132, 163, 184.

${ }^{149}$ Gough, 132.

${ }^{150}$ Gough, 132.
} 
unnamed daughters of Bartholemew Mansell II, Gough dubs them "both handsome, orderly, and modest women ..."151 The one notable exception to this notion is Margery Muckleston, who although wealthy was "short sighted and not at all beautifull." Gough, however, judges her "a very vertuouse good woman" nonetheless, who kept dairy cows and sold her milk often in town and later found a husband in Robert Hayward. ${ }^{152}$ In Gough's mind, perhaps Margery's industriousness somewhat made up for her physical deficiencies.

Gough also clearly views physical attractiveness and fitness as positive attributes for male members of the community. As mentioned, one of the few comments he makes about his own father is that he was both physically active and agile. Gough's grandfather, Richard Gough IV, was "a proper tall man."153 Although he lacked a good education, William Hanmer II possessed "good naturall parts" and "comely liniaments of body" and Gough pronounces that "for a nimble strength and activity of body none in the parish exceeded him." ${ }^{154}$ Similarly, the much-praised Richard Hayward held "an upright strait stature," and was tall, with a "leane body" and small legs. ${ }^{155}$ Thomas Lovett too possessed "an upright straite stature," a handsome complexion, and was both "skillful and ingeniouse in any worke that he undertooke." ${ }^{156}$ If modesty was the desired behavioral attribute for a woman, it seems skill and industriousness were the dual ideals for men.

Inversely, the above paradigm is mirrored in some of Gough's notations of physical abnormalities. When cataloguing the Reve family of Billmarsh, Gough links physical deformity

\footnotetext{
${ }^{151}$ Gough, 153.

${ }^{152}$ Gough, 281.

${ }^{153}$ Gough, 168.

${ }^{154}$ Gough, 169.

${ }^{155}$ Gough, 278.

${ }^{156}$ Gough, 210.
} 
with immorality in the case of George Reve in particular, whom Gough pronounces was "the ruine of the whole famyly" and who would "spend a groate beefore hee had gott two pence." Reve was apparently born with one leg shorter than the other, and Gough recalls of him the old proverb: "Beware of him whom God hath marked." ${ }^{\text {"157 }}$ Likewise, local chicken thief John Aston "was a person of a deformed countenance and a mis-shapen body," and though he was convicted and fined for his crimes, he apparently did not entirely change his ways, Gough noting that "[a] fox cannot change a pelt for hair." ${ }^{158}$ In other words, a tiger cannot change its stripes: some people were born wicked and simply could not be changed, Gough concludes.

But, in spite of Gough's deterministic stance regarding John Aston, like so much else in his work, the relationship between physical appearance and moral behavior was not always a straightforward one. Gough, for example, subsequently becomes less fatalistic, for though Samuell Downton had a crooked back and a dark complexion, "hee was not so deformed in Body as debauched in beehaviour. ${ }^{\text {"159 }}$ It thus appears that physical deformity was sometimes a manifestation or sign of a bad character, but immoral behavior was by far the worse transgression and therefore judged more harshly.

There are other various traits that Gough praises throughout the text, such as an even temper and easygoing nature, as was exemplified by Dorothy Kinaston, the eldest daughter of Phillip Kinaston, as well as the "peaceable" and "well beloved." Thomas Lloyd. ${ }^{160}$ But, an avoidance of conflict in general and patience and prudence in dealing with neighbors is applauded for men as well as women. In describing the behavior of Richard Lloyd of Myddle,

\footnotetext{
${ }^{157}$ Gough, 128.

${ }^{158}$ Gough also writes of Aston that he was "In wings an angel, in foot a thief, in voice hellish." Gough, 146.

${ }^{159}$ Gough, 197.

${ }^{160}$ Gough, 85, 95 .
} 
who claimed a right-of-way over the property of Mr. Gittins's property near Penbrooke, Gough quotes Cato: "Even in that which you can overcome, you will sometimes suffer to conquer, / for patience is always the greatest virtue of all good qualities." ${ }^{161}$ In this, Gough holds esteem for respectable and mild-mannered individuals who were unlikely to make waves in the community. For instance, Richard Gittins II, a member of one of the largest landowning family in the aprish, was charitable in addition to being calm and peaceable and often "willing to forgive the injuryes that hee passed by many without seeming to take notice of them," the most Christian of behavior. ${ }^{162}$ Mr. Zanky, the Rector of Hodnet who purchased Balderton Hall from John Nocke, perhaps deserves special mention, for in addition to being commended for his virtue, he was also praised for his piety. ${ }^{163}$

Though a bit sundry, Gough occasionally notes other attributes as praiseworthy. Elizabeth Corbett, for example, apparently lived to the ripe age of at least eighty years old and Gough reports having seen her read a letter without the use of spectacles." ${ }^{164}$ As a possible reflection of Gough's emphasis on property and land ownership, Thomas Hayward II receives Gough's admiration for his apparently well-manured lands and skill at husbandry. As well, Gough twice writes that Hayward was a good scholar who wrote with an attractive clerk's hand. ${ }^{165}$ Gough also remembers his Aunt Katherine, an overweight woman who apparently moved on cat's feet, something that admittedly struck Gough as being "a very strange thing."166

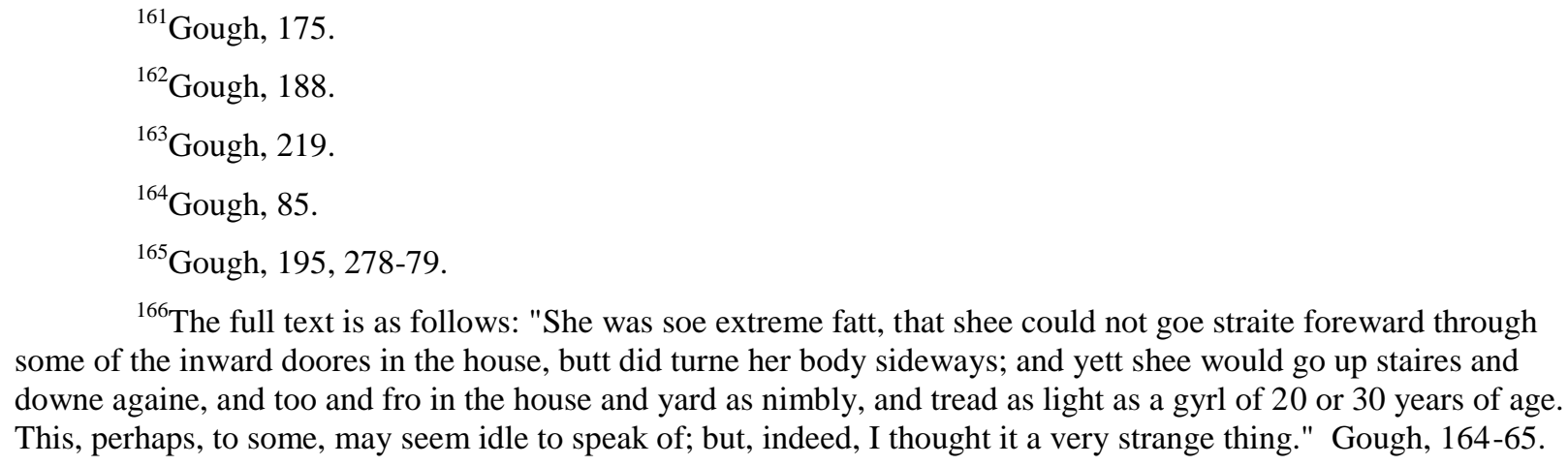
some of the inward doores in the house, butt did turne her body sideways; and yett shee would go up staires and downe againe, and too and fro in the house and yard as nimbly, and tread as light as a gyrl of 20 or 30 years of age. This, perhaps, to some, may seem idle to speak of; but, indeed, I thought it a very strange thing." Gough, 164-65. 
What to make of these more varied types of remarks is an amusing question of the type that the historian rarely gets the chance to answer, and they epitomize the unrivaled richness of Gough's narrative. These are the tidbits of history that rarely make it into official records, and in general for Gough these were the various sorts of people who made up society in Myddle.

There are many more references, however, to immoral behavior in The History of Myddle. Idleness, drunkenness, profligacy, and greed are repeatedly condemned. In addition, Gough details overt instances of violence in Myddle and mentions at least five murders, an accidental death, and one suicide. Gough cites the murder of a servant maid by Hugh Elks, Thomas Elks's abduction and murder of his nephew in a wheat field, that of Thomas Newton by Charles Hesketh, and Richard Eavans's murder at the hands of Laurence Bassnett and Matthew Hinton. ${ }^{167}$ In a somewhat lengthy diatribe detailing the immoral deeds of Richard Clarke of Myddle Wood, Gough reveals that Clarke, by way of his horrible mistreatment and abuse, pushed his father-in-law Richard Wolph to suicide after securing his property through a maintenance agreement. Wolph was buried at a crossroad instead of the parish churchyard, according to the common custom. ${ }^{168}$

Men are not the only ones singled out for homicide in Gough's account of community morality. Although he records that he speaks only from hearsay, Gough brings up the death of the daughter of Osmary Hill, who was struck in the head by her mistress after the elder woman had observed what she perceived as flirting between the girl and the master of the house. ${ }^{169}$ Most

${ }^{167}$ Gough, 121, 122, 284-85, 287.

${ }^{168}$ Gough, 173 .

${ }^{169}$ Gough explains the reported incident in full thusly: "Hee had one daughter who was servant to a gentleman who lived neare Wellington, and as this young woman was holding water for her master to wash his hands in the kitchen, hee cast a litle water from off his finger into her face, which her mistress (who was present,) seeing, and conceiving it too familier an action, shee in a rage tooke up the cleaver, and gave her such a blow on the head that shee dyed. 'Audita tantum loquor [I speak only from hearsay]."' Gough, 127. 
astonishing of all, however, is Gough's discussion of the poisoning of a Mr. Onslow by his wife, Elizabeth. According to Gough, it was rumored that Elizabeth had entered into a wicked pact with two other wives to poison their husbands, all of the women having grown weary of them. Only Elizabeth Onslow was successful, however, and though she was arrested and tried in Shrewsbury, she escaped the gallows for her crime. ${ }^{170}$

Reflecting other sources of conflict within the community, The History of Myddle records a fair share of marital discord, including the arguments between Rowland Muckleston and his second wife Darter Hesketh that turned so violent that Hesketh lost an eye. ${ }^{171}$ The bulk of the disagreements Gough lists are less violent, however, such as the earlier example of the frequent rows between Thomas Jukes and Sir Humphrey Lea over lawn bowls. Here, Gough rebukes Jukes for befriending his social betters and then taking "noe more account of Sir Humphrey, than if hee had beene a plow-boy."172 The lesson here that Gough dispenses is that one must know his or her proper place in society. Not surprisingly given their link with property and social status, the church seats themselves seem to have spurred at least occasional conflict, as in the disagreement between Thomas Atcherley and Humphrey Hanmer over rights to the fourth pew on the north side of the north aisle. ${ }^{173}$ Also appearing in the text is the example of Richard Freeman, who when Thomas Wright's widow and his eldest son Joseph prevented him from sitting in the pew connected with Wright's land in Marton, was allowed to build a seat for himself and his family at his own cost on the former spot of the baptismal font. Gough twice points out that Freeman was a "peaceable" man who "left a good name beehinde him" and as

\footnotetext{
${ }^{170}$ Gough, 148-49.

${ }^{171}$ Gough, 200-201

${ }^{172}$ Gough, 97.

${ }^{173}$ Gough, 94-95.
} 
such, his erecting of a pew was illustrative of his generally harmonious nature that sought compromise and the prevention of conflict. ${ }^{174}$ Episodes like these also underscore the interconnectedness between people and property.

Gough also criticizes those who cheated the honest and respectable people of Myddle, or liars, swindlers, and thieves. He notes that Nathaniel Reve "was such a notoriouse Lyer that hee was scarce believe in any thing he spoake ..." ${ }^{175}$ As befitting his other activities, Richard Clarke, who seems to have operated as a sort of early modern conman, often pretended to be a beggar in a similar fashion to Humphrey Beddow's mother-in-law Sina Davies, by putting on an old ragged coat while he was a soldier in the Parliamentary army during the Civil War. ${ }^{176}$ Randle Cooke, who moved to Balderton after failing to pay rent at his former residence, attempted to invest in the Cheshire cheese trade. Cooke, Gough reports, bought a great quantity of cheese on trust but then fled, with several decent people losing money in the kerfuffle. ${ }^{177}$ Gough mentions that Richard Chaloner was ordered to appear at the assizes for theft of his relative's cow, and Chaloner was also suspected of attempting to rob Thomas Atcherley one night as he was walking home from the market at Oswestry. ${ }^{178}$ George Pickering was well known for reselling stolen goods and Gough notes, perhaps as a commentary on his comorbid laziness, that his lands were so overgrown that they were "a fitt receptacle for stolne [stolen] beasts and horses." ${ }^{179}$ The misdeeds of John Aston have already been mentioned, but Gough notices that Aston's thefts of poultry were at first ignored, until he started stealing chickens at

${ }^{174}$ Gough, 184-85.

${ }^{175}$ Gough, 128.

${ }^{176}$ Gough writes that Clarke "had a smooth way of flattering discourse, and was a perfect master in the art of dissembling. Gough, 171.

${ }^{177}$ Gough, 282.

${ }^{178}$ The text once again reads "Oswaldstrey," but refers to the neighboring parish of Oswestry. Gough, 238.

${ }^{179}$ Gough, 144. 
night and selling them to accomplices in Shrewsbury. He was eventually arrested for stealing an astonishing twenty-four chickens and narrowly avoided being hanged when the value of the chickens was fixed at 11d, just one pence shy of the limit for hanging. Unfortunately, his lucky escape did not seem to spur him to change his ways. ${ }^{180}$ William Tyler, too, numbered theft among his various transgressions, and Gough reports that he had once stolen a goat from Gough's own father. His acquittal notwithstanding, Tyler died penniless, with no money left even for a "meane funerall." ${ }^{181}$ For Gough, trying to cheat the system did not pay, and he twice quotes the old proverb: "Ill-gotten gains will scarcely be enjoyed by the third heir."182

Nevertheless, it seems that Gough reserves most space to criticism of the more mundane yet pervasive issues that make The History of Myddle such a valuable source for disharmony within the parish. For example, another type of disagreement that Gough references is that related to marriages, specifically parents disapproving of a child's choice of marriage partner, which upset family hierarchy and social order. Both sets of parents were dissatisfied when Richard Cleaton, whom Gough reports was "an untowardly person" married Annie Tyller, the daughter of William Tyller, a woman who was, according to Gough, "a woman as infamous as [Cleaton] himselfe." 183 Reportedly, neither Annie's nor William's parents gave the couple any maintenance. Of this unfortunate match Gough philosophically remarks that it is often the case that like is often attracted to like. ${ }^{184}$ Another apparent unhappy pairing was made between Elinor

\footnotetext{
${ }^{180}$ Gough, 145-46.

${ }^{181}$ Gough, 179.

${ }^{182}$ Waddell writes that "it was claimed that 'ill-gotten riches' would not last for three crops or, more often, for three generations" and goes on to detail numerous examples of "supernatural punishment for economic misbehaviour" that appear to have been common in England during the latter half of the seventeenth century and early part of the eighteenth. Waddell, 57-58, 58 n. 116; Gough, 126, 138.

${ }^{183}$ Gough, 92, 93.

${ }^{184}$ Gough, 93 .
} 
Buttry and Richard Hussey, a betrothal that was secured when both were very young. ${ }^{185}$ Gough criticizes this practice, noting that Richard's father John perhaps had in mind the story of old January and lady May from Chaucer's Merchant's Tale: "A yong thing a man may gy, / As warm hand do wax ply." ${ }^{186} \mathrm{He}$ additionally cites the apparent old English proverb that "to marry children togeather, is the way to make whoremongers and whores . . ." ${ }^{187}$ Elinor, it seems, found no happiness in the match and had an affair with her neighbor William Tyler, whose poor morals were infamous in the parish. Her husband eventually left her, but gave her a portion of $£ 100$. She, however, continued to take up with Tyler and eventually had a child by him. ${ }^{188}$

On the other hand, Gough subsequently refers to the marriage of his sister Dorothy's daughter, Dorothy Glover, to John Vaughan of "Lluin y Groise [Llwyn-y-groes, Ceredigion?]," which was made when they were both so young, their ages failed to add up to thirty; nevertheless, Gough says that "[t]hey live lovingly togeather, and have many children." ${ }^{189}$ It nonetheless appears that securing the approval of both parents and even friends was an important consideration before marriage. When Gough discusses his own sister Dorothy's second marriage, he interpolates that she married her second husband "against the consent of her friends." 190 Not even a widow, it appears, was always a free agent.

Reflecting the importance of property to the organization of his work, Gough frequently laments the evils of alcoholism and profligacy for their roles in the wasting of estates. In fact,

${ }^{185}$ Gough alternately gives Elinor's surname as Butter. Gough, 124.

${ }^{186}$ Or, in more modern parlance: "A young thing, now, a man may guide, / Mold in his hands till he's satisfied." Geoffrey Chaucer, The Canterbury Tales: In Modern Verse, ed. Joseph Glaser (Indianapolis: Hackett Publishing Company, Inc., 2005), 193; Gough, 124.

${ }^{187}$ Gough, 124.

${ }^{188}$ Gough, 124-25.

${ }^{189}$ Presumably, Llwyn Y Groes, Ceredigion County, just south of Aberystwyth, or the location of the same name in Bridgend, near Cardiff, the former place being somewhat more likely due to proximity. Gough, 169.

${ }^{190}$ Gough, 169. 
drunkenness is the vice that receives the most attention within The History of Myddle, and condemnations of the abuse of alcohol are peppered throughout the text. Despite the fact that William Crosse had come from "poor parentage," his conscientious mother was still able to secure him a good education, and later he even managed to obtain a good estate and "a faire house" in the vicinity of Yorton. ${ }^{191}$ For Crosse and his wife, Judith Whitcombe, drink ruined all, however, and he quickly wasted his wife's dowry and soon after lost his lands. Afterwards, the couple moved to Billmarsh, but Crosse and his wife visited the alehouse daily and their behavior resulted in the loss of their livestock as well. Eventually, Crosse moved to Shrewsbury, where his state had much decreased, and he died soon after in an alehouse. Again, Gough laments the inability of the morally corrupt to change their behavior, writing: "The sky, not the spirit, changes for those who travel across the sea." ${ }^{192}$ Not even removal to a new environment could redeem a corrupt spirit.

Richard Preece II, "the saddest drunkard" Gough had ever heard of, also ruined his estate to such an extent that after his death, his sister Jane maintained his widow out of pure charity. ${ }^{193}$ The aforementioned Richard Clarke wasted his first wife's dowry before managing the dubious distinction of rejection by local Quakers, Protestants, and Catholics. He allegedly let his second wife Anne die in childbirth, and, as mentioned, abused his third wife's father with such drunken fury that he eventually drove the man to suicide. ${ }^{194}$ Alcohol had also seemingly played a role in

\footnotetext{
${ }^{191}$ Gough, 130

${ }^{192}$ Gough, 130.

${ }^{193}$ Gough, 133.

${ }^{194}$ Gough reports that he allowed his second wife to die in the sense that he had saved her during a previous pregnancy by making iron hooks to help draw the child out, on the midwife's advice, and refused to allow the midwife to do the same the second time. In any case, Clarke is portrayed a reprehensible figure, and the only positive thing Gough can say of him is that he did have some skill at handicrafts, for despite never having been made an apprentice to a particular trade, Clarke "was very ingeniouse" in putting his hand at any craft to which he had a mind. It appears that this talent was mostly wasted, however. Gough, 171-73.
} 
the murders of both Thomas Newton and Richard Eavans. ${ }^{195}$ After detailing the second and third parish settlement cases involving family members of Humphrey Beddow, Gough laments: "Thus you have seene (in three contests) what great trouble and costs wee have been att about this outcomne drunken Cobler and his famyly." ${ }^{196}$ Gough goes on to say that the parish had twice attempted to apprentice Beddow's son, who subsequently absconded and ended up in prison. ${ }^{197}$ (Various settlement cases involving the Beddow family also form part of those addressed more completely in chapter three, while the apprenticing of Daniel Beddow is discussed in chapter six.)

However, the case of Thomas Hodgkins is perhaps the best illustration of Gough's fundamental view of the evils of drink. Gough notes that at first, when Hodgkins would drink, no one could understand him. His condition eventually deteriorated and he was drunk so frequently, that it came to the point where no one could understand him when he was sober, an apparently quite irregular event. ${ }^{198}$ In metaphorical terms, Hodgkins's use of alcohol had turned into such a pervasive vice that it corrupted the man's character entirely and rendered him completely incomprehensible to decent folk. Yet, alcohol was a problem that harmed more than just the individual, and in Myddle it frequently resulted in indebtedness and loss of property as well. Even in the case of sexual misconduct, a cuckholded man primarily received censure in terms of his failure to regulate his household, whereas a woman was criticized for lasciviousness, loss of self-control, and ruination of family honor. ${ }^{199}$

\footnotetext{
${ }^{195}$ Gough, 284-88.

${ }^{196}$ Gough, 257.

${ }^{197}$ Gough, 257-58.

${ }^{198}$ Gough, 192.

${ }^{199}$ Laura Gowing succinctly sums up the key difference, in that "women's adultery principally dishonoured their husbands," who were tasked with maintaining not only the honor of their wives, but also their mothers and
} 
In the end, Gough ultimately gives the impression that there were far too many Mrs. Higleys, whose husbands were chronically lazy, careless, and drunken. Such men consumed their estates in drink while their wives' "paines, care, and industry" were disregarded, leaving them to depend on their relatives for charity. ${ }^{200}$ Similar critiques - and gendered expectations appear in "The Beggars Song," a seventeenth-century ballad that describes how such lazy, dishonest men left their wives to compensate for their irresponsibility:

When we have Travelled all the day, and then come home at night, We can our Wives and Children Treat, with joy and great Delight;

And then we do our Farthings send, to the Ale-house for Strong Beer, So do we live, and Merry are, with this our dainty Chear.

Our Wives they do take care for Rent, by Spinning, or such work, While we do Ramble all the day, and in some Corners lurk;

To get a Farthing here and there, as Providence doth give,

The House-keeper doth take more care, then we do for to Live. ${ }^{201}$

Another poem, "A Looking-Glass for a Bad Husband," urges men to avoid gambling, loose women, and above all the alehouse, which was full of vice, and encourages those husbands "blest with a good careful Wife" to "Be loving unto her / all dayes of thy Life."202

sisters. Laura Gowing, Domestic Dangers: Women, Words, and Sex in Early Modern London (New York: Oxford University Press, 1998), 94-95.

${ }^{200}$ See also Waddell's analysis of Gough's writings concerning "bad husbands" who failed to adequately provide for their families. Waddell, 100; Gough, 276.

201 "The Beggars Song, Both in City and Country ..." (1686-1688), Magdalene College, Pepys Library, Pepys Ballads 4.250, English Broadside Ballad Archive (EBBA), University of California Santa Barbara, EBBA ID: 21910, accessed 11 December 2017, https://ebba.english.ucsb.edu/ballad/21910/xml 
These ballads illustrate how abuse of alcohol and profligacy went hand in hand, and Gough repeatedly remarks that alcoholism was the foundation for mounting debts and the loss of property. Indeed, perhaps this is why he scorned wastefulness, for it is property that stands at the heart of The History of Myddle. Significantly, property also stood as physical proof for a man's industriousness and hard work, another major theme within the work. Thus, Gough is critical of improvidence and in general voices disapproval of individuals whiling away their day in alehouses, drinking and cavorting, when they could be spending their time more productively. As far as indebtedness in Myddle, at least one attempt to collect a debt resulted in violence. Although but one of the escapades of the renowned scoundrel William Tyler, when Reece Winlocke attempted to serve Tyler a writ due to debts owed to Thomas Bradocke, Tyler stabbed Winlocke in the leg, and was later able to escape while Winlocke was being arrested for his role in the altercation. ${ }^{203}$ Gough similarly disparages Thomas Baker, Jr. who was so addicted to gambling that he spent the inheritance he received from his father. It appears that he improved himself, but in later years "became rich and covetuouse," deciding to choose the flip side of the moral coin and lapse into greediness instead, perhaps in a bid for variety. ${ }^{204}$

In fact, avarice is recurrently criticized. Even though he had plenty of money, John Matthews was so parsimonious that he failed to even properly feed or clothe himself. ${ }^{205}$ However, Gough passes harsher judgment on the greediness of the Wicherley family. Gough writes that both James Wicherley and his son Richard were greedy, with James forbidding the

\footnotetext{
${ }^{202}$ In the end, "those that are careful / their money to save, / They doth maintain their / Family gallant and brave." Thomas Lanfiere, "A Looking-Glass for a Bad Husband: Or, a Caveat for a Spend-thrift ..." (London, 1678-1688[?]), Houghton Library, Huth EBB65H 1.149, EBBA, University of California Santa Barbara, EBBA ID: 35241, accessed 11 December 2017, https://ebba.english.ucsb.edu/ballad/35241/xml.

${ }^{203}$ Gough, 176-77.

${ }^{204}$ Gough, 157.

${ }^{205}$ Gough, 147.
} 
marriage of his eldest son, also named James, to a neighboring woman because her dowry was not large enough. Sadly, James Wicherley II, still in love with the woman, fell and broke his leg while trying to slip off to see her, and died. Apparently, the apple did not fall too far from the tree, for Richard Wicherley was just as parsimonious as his father. In a severe rebuke, Gough advises that he had not once heard him "commended either for his charity to the poore, his hospitality to his neighbors, nor his plentifull housekeeping for his servants." ${ }^{206}$ In like manner, Gough condemns Robert Hayward for attempting to prevent the residents of Myddle from using a well on his property. Gough states that he told Hayward himself that it was not only their right by custom but also unjust and mean-spirited "to hinder people of that which God sends freely." 207

Even though the connection between men and the world of property and finances was a more direct one, women could also be ruinous through the same moral transgressions as their male family members. In fact, Gough's narrative communicates an interesting relationship between women and alcohol. Even though there are plenty examples of men wasting their wives' dowries, some women could be just as ruinous. That Michael Chambre associated with "lewd consorts" and "ugly nasty bawds" only served to further impugn his character. Echoing the connections made elsewhere between inner character and outward appearance, Gough writes that these unidentified women "might almost resemble uglinesse itselfe, and as such they were the very scorne of the greatest and vilest debauchees of this parish, of which, (the more the pity,) there were too many in this parish." 208

\footnotetext{
${ }^{206}$ It appears that the Wicherley name continued to remain unremarkable: though Richard had no children, he adopted a relative as his heir, a man also named Richard Wicherley. Gough dubs Richard Wicherley II "very dull at learning," but prosaically notes that he must have had "geare in his britches" for he did manage to get one of his uncle's servants with child. Gough, 138-39.

${ }^{207}$ Gough, 266.

${ }^{208}$ Gough, 218.
} 
Undoubtedly reflecting long-standing ideas about the relationship between women and sin, women could not only abuse alcohol themselves, but they could also drive men to the alehouse door and lead them into immorality through their own behavior. For example, Judith Downton, spent her husband Thomas Downton's estate "soe fast that it seemed incredible." 209 Gough also hints that the fact that Judith had worked as a servant in an alehouse in her youth had some negative impact on her character. In another example, Thomas Hayward II's wife Alice Wihen, was so "shrewed with tongue" that poor Thomas "had litle quietnesse at home," which caused him to patronize local alehouses and eventually resulted in him squandering his estate and being supported by his eldest son, Robert. ${ }^{210}$ Gough makes it clear that Thomas was forced to go into the pub, not just for alcohol, but for sustenance, and would go there to buy meat as well as drink. His wife Alice, meanwhile, mostly stayed at home. It seems she aroused some resentment because she was "a towne-bred woman" who was "unfitte for a country life."211 Gough plainly places the blame for Hayward's rising debts on Alice and points out that as a town woman she often required rich clothes and expensive food. Though Heyward's estate declined, Gough maintains that he "still boare an honest mind."212

Moreover, Gough is intermittently critical of women who challenged the natural, patriarchal, order. Gough criticizes Darter Hesketh, the aforementioned second wife of Rowland Muckleston, for although she was handsome, she had "a masculine spirit" and sought to keep her

${ }^{209}$ Gough, 198.

${ }^{210}$ Gough later repeats much of this information when he again discusses the Hayward family, except here he writes that Thomas was taken care of not by his eldest son, but by his brother, who was also named Robert. It is unclear which of these assertions is correct. Gough, 195, 278-79.

${ }^{211}$ Gough, 279.

${ }^{212}$ Gough, 279. 
husband out of her domestic affairs. ${ }^{213}$ Gough seems to note with irony that although she strove to keep a good house, she instead caused much domestic disorder, and the rows between husband and wife occasionally came to blows. In fact, Gough criticizes laziness in women as much as he does in men, disapproving of both "light" and "idle" housewives. ${ }^{214}$ Nonetheless, his basic attitude is revealed when he discusses the infamous Judith Downton, where he admonishes: "It is not prudent to marry a bride whom you cannot guide."215

Most naturally, Gough's most strident criticism of women neglecting to conform to their natural roles is reserved for mothers who fail to properly raise their children. To be fair, Gough does not always place the blame for bad parenting solely on the mother's shoulders and points out that his own brother-in-law, Richard Glover, was too lenient in his treatment of his son John, a young man who was yet another resident of Myddle ruined by alcohol. ${ }^{216}$ Even so, he blames the bad character of the Beddow children not on Humphrey Beddow the drunken cobbler, but on their mother, "who brought up her children in idlenesse, and favoured them in theire bad courses." 217 Gough writes that Beddow's wife had in turn learned bad traits from her own mother, the notorious beggar Sina Davies. Gough also condemns the grandmother of Thomas Elks, who raised him, for favoring and indulging him. Gough hints that this perhaps played a role in his later murder of his nephew, who stood in the way of Elks's inheritance. Elks hired a man to lure the child away and Elks himself then brutally drowned the poor child in a bucket of

\footnotetext{
${ }^{213}$ As well, Gough mentions that Thomas Baker, Jr. married a woman possessing "a masculine spirit." Gough, 159, 201.

${ }^{214}$ Gough, 133, 221, 227.

${ }^{215}$ Gough, 198.

${ }^{216}$ Gough, 165.

${ }^{217}$ Gough, 257.
} 
water. $^{218}$ In these instances, bad wives and mothers were corrupting influences and her moral defects both inheritable and transmissible, reflecting the wider idea that a dishonorable woman was a danger not just to herself and family, but to society as well. ${ }^{219}$

\section{Conclusions: Beating the Bounds of Order and Respectability}

Despite Gough's social position and the various biases inherent in his focus on the propertied classes, there are hints of a perceived older and more equitable world. Suggestions of a moral order appear in the various references to neighborliness and charity. They are also there in the rebuking of Thomas Highway for trying to rent out his pew seat, as well as in the frustrated attempt of Robert Hayward to stop Myddle's residents from using his well. They are seen in Gough's exhortations against greed, to not covet more than one is due, and to be satisfied with one's lot in life. Hints also bubble to the surface early in the text when Gough lays out the differences between custom, prescription, usage, and limitation. Prescription is a right applied to one person in particular, usage is limited by the length of one's life, while limitation is restricted by a certain time period - a period of several years, for example. Custom, however, is altogether different: it is at once much more imprecise and elemental. In Gough's definition, custom has "noe beginning since man's memory" and simultaneously "toucheth many men in common ..."220 As his example, Gough mentions that at one time each household had the right of free panage, that is, the right to allow their swine to graze in the lord's forest, after paying $4 \mathrm{~d}$ per year for the privilege. According to Gough, because the woods had been cut down, the right had been lost. ${ }^{221}$ Quite simply, the world had changed.

\footnotetext{
${ }^{218}$ Gough, 122.

${ }^{219}$ Gowing, 99.

${ }^{220}$ Gough, 64.

${ }^{221}$ Gough, 64.
} 
Nevertheless, The History of Myddle fundamentally represents an attempt to bring order to a disordered world, which is symbolized most starkly in the grid-like seating plan of Myddle's parish church reproduced within the work. Conceivably, with a dead wife and four sons weighing heavily in his thoughts, one of the reasons Gough sat down to write was out of a desire for a sort of tidy regularity he wished existed in reality. Taken as a whole his is a world in which the prosperous are customarily also charitable, all those who work can never sink into want, and thieves are justly punished. Gough's predecessor, White Kennett, records that his own local history began as an attempt to settle a dispute over church lands in the Oxfordshire parish of Ambrosden. According to Kennett, this disagreement "was the occasion which first engaged me in inquiries and searches after papers and records, which might any way relate to my church and parish." ${ }^{222}$ Importantly, it is not order but disorder that is Kennett's catalyst. Similarly, Gough in setting down The History of Myddle in ink gives physical form to Myddle's history, thereby legitimating it. A history such as this also embodies an assertion that the way things came to be the way they are is lawful. The most honorable families are such because this is the natural order of things. ${ }^{223}$ In a manner of speaking, though Myddle is far from perfect, it is the proverbial best of all possible worlds, where everyone's place in society is clearly laid out. Gough's moral judgments also reflect the benevolent paternalism that was so much a part of the poor laws that was espoused by legislators and rate payers and meant to lift up the poor and help them join respectable society.

\footnotetext{
${ }^{222}$ Kennett, ix.

${ }^{223}$ In fact, nature itself was occasionally involved in the regulation of the proper moral order, as in the case of Thomas Elks murder of a young boy. After Elks had escaped and a search party was sent out after him, two ravens pointed the men towards Elks, who had been hiding in a haystack. Elks then tearfully confessed that the ravens, perhaps a manifestation of his guilty conscience, had been following him "from the time that hee did the fact." Gough, 122.
} 
Though a sense of community undoubtedly pervades The History of Myddle, it can be argued that there exist only a few hints and traces of an E. P. Thompson-esque moral economy. After all, Gough reads from above rather than below. He discusses enclosure, for instance, but these references are mostly nonjudgmental. In actual fact, Gough records that he himself was the very person who measured a field owned by Robert Hayward, Thomas Mather, and Richard Tyler, so that the land could be enclosed. ${ }^{224}$ Likewise, and as will be shown, Gough's narrative surrounding the eight various parish settlement cases within The History of Myddle even more starkly indicates his prejudices, in its betraying a concern over the poor in a fiscal rather than a moral sense. Though Gough's purpose in describing these cases is arguably not primarily moral to begin with, the text seems to communicate a somewhat dispassionate view of the poor and their plight. Ultimately, Gough's concerns were the concerns of England's rural propertied classes, and his emphasis on property and lineage means that the rootless and transient, who had neither, are generally viewed negatively.

At its fundamental level, The History of Myddle is best seen as reflecting the perspective of a propertied man concerned with ordering his world. As such, Gough provides a backdrop depicting the sort of moral behavior expected of everyone in the parish. Still, being the member of an "ancient" family or coming from a long lineage was but one of the ways in which a person could be judged as respectable. ${ }^{225}$ It is plain that Gough has made room for many types of individuals within his community, and notably he opens the door to families such as his own those industrious families who through hard work, thrift, and it must be said, a good measure of

\footnotetext{
${ }^{224}$ The detrimental effects of enclosure are of course both well known and extensively documented. Enclosure reduced the supply of land and made rents and land values increase. Things only further deteriorated after the period documented by Gough, and after 1750 more and more families experienced temporary periods of poverty. Gough, 126-127, 281; Steve King, "Reconstructing Lives: The Poor, the Poor Law, and Welfare in Calverley, 1650 1820." Social History 22, no. 3 (October 1997): 322.

${ }^{225}$ Henry French, 75.
} 
luck, had been able to rise to the rank of the respectable sort of property owners who ably served their parish and community. To be sure, these types of boundaries - those of class, which could be somewhat transgressive, and those of gender, which were much more fixed - were not barriers. Yet, they signified limits all the same. The poor who passed through Myddle, including Humphrey Beddow, Michael Chambre's nameless and faceless bawds, and even the hardworking Anne Parkes, who managed to knit enough to pay for her own funeral, were certainly well acquainted with these. 
$\begin{array}{lllllll}\text { CHA P T E R 3: } & \text { "N O T O W N W I L L I N G L Y R E C E V IES A }\end{array}$ \begin{tabular}{lllllll}
\hline POOR MAN": & SETTLEMENT IN THE HISTORY OF
\end{tabular} $M Y D D L E$

\section{Introduction}

This chapter examines how one's settlement within the early modern English parish was determined. Settlement appears a thorny matter that depended much on both the fiscal concerns of the parish and the interpretation of local authorities. As such, it was in this sense was defined by elites. Though poor law documentation is by its very nature biased, and in fact sometimes hostile towards the poor themselves, it nevertheless allows for the reconstruction of what life was like for the poor people who passed through the parish, even if it does not often reveal what the poor thought of the poor law system and their place within it.

Specifically, this chapter isolates which factors affected settlement, according to governmental legislation, such as the 1662 Act of Settlement and various other statutes, together with more local issues, like parochial financial concerns. This is also accomplished through examination of several sources relating to poor law administration within the parish of Myddle. The first of these is Richard Gough's The History of Myddle. ${ }^{1}$ As part of this work, Gough provides commentary on eight settlement cases involving Myddle and several assorted parishes. Throughout his narrative, Gough betrays a concern over preserving Myddle's resources and communicates larger societal anxieties regarding the idleness and immorality associated with the poor. Because of this perspective, and his generally negative estimations of the various paupers' characters, Gough discloses no discernable concern for the individual paupers themselves. County-level quarter sessions records and parish chest records of poor law administration in

\footnotetext{
${ }^{1}$ Richard Gough, History of Myddle, edited and with an introduction and notes by David G. Hey (New York: Dorset Press, 1986).
} 
Myddle dealing with these same eight cases supplement The History of Myddle and complement Gough's writings on elite views of the poor.

Both Gough's text and court and parish records unearth official attitudes about the poor and uncover how the process of poor law administration worked within Myddle. Fundamentally, they illuminate the complex web of factors that went into determining a pauper's parish

settlement. Arguments about settlement rested on a spatial sense of geographical boundaries and frequently involved such issues as age, gender, an individual's perceived propensity to fall on parish relief, and questions over the ability of extended family to provide financial support. For men, their labor was often the central issue, as their employment, whether contracted through apprenticeship or hiring contract, was the key determinant of the parish of settlement. Parishes of settlement for women and children, in contrast, were established not through employment, but on the spatial nature of life events such as marriages and births. Importantly, these were occasions characterized by women's respective relations to their husbands and fathers. In other words, settlement for women and children was defined by their relationship to others, while settlement for men was defined by their labor, uncovering the ways in which settlement was gendered. Gough's group of settlement cases is also highly colored by moral judgements, and paupers are frequently accused of such vices as laziness and sexual immorality, behavioral defects that are often similarly split along gendered lines. Indeed, precisely because of such biases, they are instructive of the various cracks the problem of poverty revealed within the early modern English community.

\section{The Growing Moral and Financial Threat of Poverty}

Due to a multi-faceted set of demographic, economic, and cultural changes in the late medieval and early modern periods, poverty became an increasing problem in England. One of 
the major shifts regarding attitudes toward the poor occurred after the Black Death, which compelled the lower classes into a fundamentally different relationship to the land and to labor. Although there appears to have existed a varied system of villeinage prior to 1348 in England, whereas the peasantry had been relatively tied to the land in the High Middle Ages, in the postplague period demographic conditions led to workers traveling in search of higher wages. ${ }^{2}$ According to Mark Bailey, though exact instigators of migration are difficult to pinpoint from the available evidence - and could indicate a flight from repression or move toward opportunity - the indisputable conclusion is that peasants now had many more choices than before. ${ }^{3}$ The result was that among the upper classes, the increased mobility of the lower classes led to fears of vagrancy and social disorder. ${ }^{4}$

Moreover, by the sixteenth century, institutional changes, some driven by religious matters and others propelled by demographic and economic issues, had made the parish the center of poor relief. In England, the Protestant Reformation affected the treatment of the poor in two significant ways. In its sweeping away of many of the medieval institutions whose roles included care of the poor - including fraternities, guilds, and most importantly, monasteries - a space was created into which the government could step. Second, the break with Rome was characterized by religious changes that were inherently bound up with political ones in such a

\footnotetext{
${ }^{2}$ As he acknowledges, the general dearth of pre-plague manorial sources makes synthesis difficult; nonetheless, the evidence that does survive - and which Mark Bailey utilizes - paints a picture of wide-ranging tenurial practices before 1348. Mark Bailey, The Decline of Serfdom in Late Medieval England: From Bondage to Freedom (Woodbridge, Suffolk: The Boydell Press, 2014), 330-31.

${ }^{3}$ Bailey, 79.

${ }^{4}$ A. L. Beier, Masterless Men: The Vagrancy Problem in England, 1560-1640 (New York: Methuen \& Co.
} Ltd, 1985), 17-18. 
way that gave the Crown the ability to take over the administration of the church and charitable institutions, which made its involvement in poor relief almost inevitable. ${ }^{5}$

Although the most sweeping poor law legislation came in 1601, an earlier 1598 statute had required parochial overseers of the poor to collect poor rates from all parish residents, which were then distributed to the parish poor. ${ }^{6}$ Gradually, the system came to be more refined, and legislation in 1662 laid down the principle of settlement, which meant that one had to be "settled" in a particular parish in order to be eligible for relief. At the same time, settlement, which in time came to be defined using several criteria, developed into a symbol of identity for the poor. These changes were such that one's parish of settlement came to represent "a notion of legal entitlement, [as well as] a welfare security," in addition to symbolizing the more nebulous but no less important concept of "home." ${ }^{7}$ Settlement laws also function as a way to keep out "the alien poor" and, much like the practice of banishment, served to mark out inclusion and exclusion within the local community through the enforcement of "socio-spatial boundaries." 8 Taxation, through parish poor rates, in turn meant that the whole community had an interest in ensuring that the system functioned fairly and efficiently, and parish officials often became aware of suspected vagrants due to information from anonymous informers. ${ }^{9}$ In the late seventeenth century, the badging of paupers, a practice that had existed across Europe during the

\footnotetext{
${ }^{5}$ Paul Slack, The English Poor Law, 1531-1782 (New York: Cambridge University Press, 1990), 8.

${ }^{6}$ Steve Hindle, On the Parish?: The Micro-Politics of Poor Relief in Rural England, c.1550-1750 (New York: Oxford University Press, 2004), 11.

${ }^{7}$ K. D. M. Snell, Parish and Belonging: Community, Identity and Welfare in England and Wales, 1700 1950 (New York: Cambridge University Press, 2006), 88.

${ }^{8}$ Jason Philip Coy, "Beggars at the Gates: Banishment and Exclusion in Sixteenth-Century Ulm," The Sixteenth Century Journal 39, no. 3 (Fall 2008): 619, 620.

${ }^{9}$ Beier postulates that slightly earlier vagrancy laws, much like witchcraft accusations, "probably reflect[ed] community tensions more than anything else." Beier, 11.
} 
late medieval period, was also reintroduced, which further served as an embodiment of taxpayers' investment in the system of poor relief. ${ }^{10}$

The above changes also meant that mobility remained at the heart of both poor law legislation at the government level and its administration within the parish. Poor relief was a complicated matter, and what resulted was a system that was ultimately fluid enough for parish officials to try and keep out the undesirables. Jason Phillip Coy studies the use of banishment to exclude the vagrant poor in the urban community of Ulm in Baden-Württemberg during the sixteenth century and finds that there legislation was also such that "it was not any specific crime that prompted the authorities to drive these unemployed aliens from the city, but rather their marginal status in local society." 11 Importantly, "[v]agrancy was a crime, but it was also a condition ..." ${ }^{12}$ In England, these types of "undesirables" were often those whose settlement in a particular parish was somehow questionable, an issue that usually stemmed from their mobility. Of equal importance was their likelihood to become chargeable to the parish. But first and foremost, because of their itinerancy, the poor were often thought to disrupt the bonds of parish community and its associated "respectable" values.

The plasticity of the system also meant that, due to the concept of settlement itself, the poor often had to re-negotiate their membership within the parish community. Settlement disputes between parishes were also common, and these inter-parish disagreements often took up much of the business at the local quarter sessions. ${ }^{13}$ Furthermore, on account of the general

\footnotetext{
${ }^{10}$ Steve Hindle, "Dependency, Shame and Belonging: Badging the Deserving Poor, c.1550-1750," Cultural and Social History 1, no. 1 (2004): 11.

${ }^{11}$ Coy, 621.

${ }^{12}$ Coy, 636.

${ }^{13}$ Quarter sessions, as their name implies, were local courts which convened quarterly. They usually took place at the county town and heard a wide variety of cases, both civil and criminal. W. E. Tate, The Parish Chest: $A$
} 
inadequacy of the system of poor relief and the very real limits of parish resources, lines had to be drawn around those who were deserving of relief - a parish's "settled" poor - and those who were undeserving of parish support - "strangers" whose settlement was determined to be elsewhere. Additionally, the process of determining one's settlement frequently involved moral judgments about the pauper in question, which drew on broader cultural ideas about poverty.

\section{The Development of the Poor Laws}

While the discrete causes of changing cultural attitudes to poverty are notoriously difficult to isolate, the first major shift seems to have occurred in the fourteenth century following the Black Death. For example, scholars such as Paul Freedman have been able to track changes in the representation of the medieval peasantry in Europe, whereby the lower classes were regarded as more dangerous and insidious, largely due to the very real threat of peasant revolt. ${ }^{14}$ Prior to the Black Death there had been a more flexible view of the rustic, one that viewed peasants as excluded from civilized society at the same time as they were recognized as necessary for that selfsame society's survival. This eventually gave way to a less malleable, and ultimately more threatening, perception of medieval agricultural laborers, which in turn translated into a sharper view of the rural poor as well. This process also saw the various merits associated with poverty being replaced by emphasis on the value of labor, and it was the laborer and not the pauper who ultimately became the symbol of morality. ${ }^{15}$

Study of the Records of Parochial Administration in England, 3rd ed. (New York: Cambridge University Press, 1969), 198.

${ }^{14}$ Paul Freedman, Images of the Medieval Peasant (Stanford: Stanford University Press, 1999).

${ }^{15}$ This is the major shift examined in Kate Crassons's interdisciplinary work, The Claims of Poverty: Literature, Culture, and Ideology in Late Medieval England (Notre Dame: University of Notre Dame Press, 2010). 
In England itself, other scholars have noticed similar shifts regarding ideas about poverty and charity. A large part of medieval religiosity revolved around charitable almsgiving. ${ }^{16}$ More specifically, Miri Rubin, in Charity and Community in Medieval Cambridge, a local study of urban charitable giving, ties charitable activity to the "'arithmetic of the soul'" that grew up in roughly the twelfth and thirteenth centuries. ${ }^{17}$ The value placed upon good works, and the charitable deeds often associated with them, was such that every deed "counted towards the final reckoning and even a single act of charity could admit a man to heaven." ${ }^{18}$

Additionally, poverty itself was considered virtuous in the High Middle Ages, which reveals that in the medieval world, there was an innate goodness associated with living in want. ${ }^{19}$ For example, many considered that a poor person was less likely to experience greed. ${ }^{20}$

Fundamentally, poverty increased the virtue of the poor at the same time as it allowed the rich an avenue to salvation through charitable acts. ${ }^{21}$ In this sense, emphasis on charity and gift-giving reflected growing unease over commercialization, and growing and affluence. ${ }^{22}$ As well, in a world where most people lived in small rural villages, and in places where everyone tended to know everyone else, the poor stranger, who was often symbolic of Christ himself, was to be

\footnotetext{
${ }^{16}$ Marjorie Keniston McIntosh, Poor Relief in England, 1350-1600 (New York: Cambridge University Press, 2012), 15.

${ }^{17}$ Miri Rubin, Charity and Community in Medieval Cambridge (New York: Cambridge University Press, 1987), 90 .

${ }^{18}$ Rubin, 86.

${ }^{19}$ Freedman delineates three main varieties of peasant virtue: first, that society as a whole depended upon their labor; second, that their suffering was spiritually valuable; and third, the fact that labor and sacrifice were intrinsically honorable pursuits. Freedman, 229.

${ }^{20}$ Rubin, 91.

${ }^{21}$ Philipp R. Schofield, "The Social Economy of the Medieval Village in the Early Fourteenth Century," Economic History Review 61, no. 1 (2008): 49; Rubin, 85.

${ }^{22}$ Lester K. Little, Religious Poverty and the Profit Economy in Medieval Europe (New York: Cornell University Press, 1978); Martha C. Howell, Commerce before Capitalism in Europe, 1300-1600 (New York: Cambridge University Press, 2010), 148-59; Adam J. Davis, "The Social and Religious Meanings of Charity in Medieval Europe," History Compass 12, no. 12 (December 2014): 942.
} 
charitably received. ${ }^{23}$ Associated with the type of virtue linked to involuntary poverty was the sort of voluntary poverty encouraged by Saint Francis, which allowed for the subjugation of material concerns and was considered virtuous and thus the best way to serve God. ${ }^{24}$

In this way, both poverty and charity were flip sides of the same coin. Both were part of the concept of imitatio Christi, or imitating the life of Christ, and charity to the poverty-stricken beggar, whether lay or clerical, was analogous to receiving Christ into one's heart. According to Marjorie Keniston McIntosh, the so-called seven corporal works of mercy "rested upon the idea that people who helped the less fortunate also served the Christ among them . .." ${ }^{25}$ Likewise, the religious virtue associated with poverty also succeeded in blurring the lines between voluntary and involuntary poverty, and prior to the Protestant Reformation, members of the begging orders were allowed to receive alms in addition to the more traditional types of poor individuals orphans, widows, the disabled, infirm, as well as those who had unluckily fallen on hard times. ${ }^{26}$ However, this does not mean to imply that such ideas were uncontested. The Church for example was split on the matter of Franciscan voluntary poverty, with antifraternalists vociferously arguing that neither poverty nor begging were virtuous activities and instead signified greed and idleness. ${ }^{27}$ Moreover, in their creation of an idealized form of poverty, the Franciscans themselves may have promoted, albeit unintentionally, more negative views of nonspiritual begging. ${ }^{28}$

\footnotetext{
${ }^{23}$ Little, 20.

${ }^{24}$ Bronisław Geremek, The Margins of Society in Late Medieval Paris, trans. Jean Birrell (New York: Cambridge University Press, 1987), 306; Rubin, 92.

${ }^{25}$ McIntosh, 15.

${ }^{26} \mathrm{McIntosh}, 5$.

${ }^{27}$ Crassons, 6-7.

${ }^{28}$ This is the fundamental point in Allison Edgren's "From Saint Francis to Salimbene di Adam: Begging in the Early Franciscan World, c.1210-80," in Approaches to Poverty in Medieval Europe: Complexities, Contradictions, Transformations, c.1100-1500, ed. Sharon Farmer (Turnhout, Belgium: Brepols, 2016), 93-115.
} 
In addition to these types of intellectual debates, a gradual dissatisfaction with both workers and the poor led to a lessening in the virtue associated with poverty, again, a change for which the Black Death was at least partly to blame. ${ }^{29}$ Due to the manifest specter of peasant revolt, combined with concerns over the post-plague rootlessness of laborers in search of better wages and idleness in an age where the labor of all was needed, the poor began to be seen as dangerous. ${ }^{30}$ Certainly, evidence from the period indicates an increased post-plague mobility, and manorial court rolls in particular appear to indicate renewed efforts to identify "emigrant serfs, either through presentments for absence or for the payment of chevage." ${ }^{31}$ As well, "heightened seigniorial concerns about migration, meant that the explicit identification of those people who were personally unfree became commonplace in manorial documents: serfs, or neifs, by blood [nativi de sanguine]." ${ }^{32}$

Such pervasive anxieties led to an increase in legislation regarding the behavior of the migrant lower classes. In England, several acts were passed between 1349 and 1388, including the 1351 Statute of Laborers, which prohibited both begging and almsgiving to able-bodied beggars. ${ }^{33}$ Elsewhere in Europe, these individuals, the so-called able-bodied poor - the foils of the impotent poor - were undeserving of relief. Soon after, beginning in 1351, a whole series of statutes restricted the mobility of the poor, a constraint that would become the cornerstone of

\footnotetext{
${ }^{29}$ Beier sees this development as part of a broader "de-sanctification" of poverty. Beier, 4.

${ }^{30}$ Beier, 4.

${ }^{31}$ Bailey, 76.

${ }^{32}$ Bailey, 60 .

${ }^{33}$ Again, developments like these were not just English phenomena, as Geremek too discusses the problem of vagabondage in France and the resultant increase in legislation aimed at the poor there. Increasingly, legislation was meant to enforce "the obligation to work, and to recognise 'voluntary unemployment' as an offence." Along these lines, Rubin notes that French legislation was often both harsher and more frequent than that in England. Geremek, 33; McIntosh, 17, 43; Rubin, 32, 98.
} 
England's poor laws for hundreds of years. ${ }^{34}$ A related concept revealed in the above labor statutes was that labor, or work, was also seen as the new ideal, and all those regarded as unproductive members of the community — the unemployed, idle, and lazy — had no place in respectable society. According to Kate Crassons, in England in the post-plague period antifraternal criticisms of voluntary poverty "fused with objections to the rising power and mobility of lay workers, [and] poverty and mendicancy came to be described more readily as signs of sinfulness than as hallmarks of Christian sanctity." ${ }^{135}$ Moreover, Rubin finds that "poverty came to be seen more as a choice than an affliction" and ultimately, the poor themselves came to be "seen as others rather than brothers." ${ }^{36}$ In short, the poor stranger had given way to the sturdy beggar. ${ }^{37}$ It was a tricky matter, for only the former was worthy of charity and the latter not, yet distinguishing between the two categories - an objective in fact often at the heart of subsequent legislation - was by no means easy or straightforward in practice. In fact, this is an enduring conundrum: it perceptibly occupies Myddle's parish officials, and indeed survives even into our own time.

In the medieval period, poor relief itself remained largely in the hands of private institutions like the manor, parish church or monastery, almshouse, and several pieces of legislation were passed addressing poverty in the later fourteenth century. In 1388, an act against vagrancy was passed, with one stipulation ordering that any beggars who could not be maintained in their present location were to be returned to their birthplaces. ${ }^{38}$ This was an early foreshadowing of the principle of settlement that would eventually become more fully developed

\footnotetext{
${ }^{34}$ McIntosh, 43.

${ }^{35}$ Crassons, 5 .

${ }^{36}$ Rubin., 293, 299.

${ }^{37}$ Beier, 12.

${ }^{38}$ Tate, 190.
} 
in the mid-seventeenth century. Although its primary purpose was to restrict the granting of land to the Church, thus alienating it from both the feudal economy and control of the Crown, the second Statute of Mortmain of 1391 specified that at least some of a benefice's surplus should be set aside for the parish poor. ${ }^{39}$ These repeated attempts at the regulation of vagrancy suggest their inadequacy as well as officials' concerns, and the fifteenth century saw the passage of several additional acts meant to help solve the problem.

Beginning in the Tudor era, there were renewed governmental attempts to deal with poverty. ${ }^{40}$ Another major cultural shift regarding poverty occurred in the sixteenth century, partly as a result of the post-Black Death demographic recovery, which saw England's population swell from roughly 2.7 million in 1541 to 5.2 million by $1652 .{ }^{41}$ Due to such a high rate of population growth, as well as the predictable inflation and heavy taxation caused by it, the number, mobility, and general visibility of the poor greatly increased, among whom there was now greater competition for resources like landholdings. ${ }^{42}$ The paradigm of the late fourteenth century had now reversed itself: whereas in the late Middle Ages there had been too few workers, in the sixteenth century there were too many, and great numbers of people went jobless. $^{43}$

These pressures were in turn compounded by bad harvest years throughout the $1520 \mathrm{~s}$, 1550s, 1580s, and 1590s, which caused food prices to rise. ${ }^{44}$ Meanwhile, even though wages

\footnotetext{
${ }^{39}$ Tate, 190; On the concept of mortmain, and its regulation by the Crown, see Kelly O'Halloran, Myles McGregor-Lowndes, and Karla W. Simon, Charity, Law and Social Policy: National and International Perspectives on the Functions of the Law Relating to Charities ([Dordrecht]: Springer, 2008), 112, 134-35, 172-73.

${ }^{40}$ Tate, 189.

${ }^{41}$ Slack, 19.

${ }^{42}$ McIntosh, 19; Beier, 21.

${ }^{43}$ Beier, 20.

${ }^{44}$ Slack, 3; McIntosh, 19, 273.
} 
were increasing throughout the period, their rise was not sufficient to keep up with mounting food prices, and real wages for agricultural and industrial labor fell by around fifty per cent. ${ }^{45}$ All of these demographic and economic factors coalesced with the occasional food riot and the general social unrest associated with large numbers of able-bodied laborers unable to find work into a harsher attitude toward the poor. ${ }^{46}$

Other factors in changing ideas about the poor have proved trickier to isolate. Intellectually, there has been much disagreement over the part played by Protestant reforming ideas about poverty. Historians such as McIntosh and Paul Slack argue that it was in fact not Protestantism per se, but humanism that introduced - or perhaps more accurately re-introduced the importance of Christian charity and moral reform, something that balanced the shift away from charity and good works, but in such a way that accentuated rationality over self interest in one's salvation. ${ }^{47}$ This shift meant that the emphasis rested more so on the receiver's worthiness of charity, rather than on the moral benefits accrued by the giver. In the sixteenth century, another important development was the concept that "public authority," or the government, should be the main force directing the control of poverty, a system that would eventually come to be maintained at the local level by the parish. ${ }^{48}$ Despite the fact that it was more of a process of fits and starts than one of linear progression, the hand of the state can nevertheless be increasingly discerned throughout the sixteenth and seventeenth centuries, in terms of it gradually becoming the source of increasingly stringent poor law legislation.

\footnotetext{
${ }^{45}$ Beier, 20.

${ }^{46} \mathrm{McIntosh}, 273$.

${ }^{47}$ W. K. Jordan, Philanthropy in England, 1480-1660: A Study of the Changing Pattern of English Social Aspirations (New York: Russell Sage Foundation, 1959), 240; McIntosh, 273; Slack, 6-7.

${ }^{48}$ Slack, 7.
} 
This was particularly true during the reigns of Henry VIII and Edward VI at a time when several English writers were highlighting humanist ideas that advocated the role of the government in combatting social ills. ${ }^{49}$ Writers and political theorists William Marshall and Thomas Starkey both lamented the high numbers and lax morals of the poor during the 1520s and 1530s. Marshall for example wrote of their immorality and lawlessness. Starkey, while writing of "multitude of beggars here in our country," recognized that the increase in the poor's numbers resulted from both idleness and "ill policy." ${ }^{50}$ In his writings, Starkey also made clear that poverty was a problem for the nation, the contextual basis for poor law legislation in the 1530s. ${ }^{51}$

In 1531, Concerning Punishment of Beggars and Vagabonds (22 Henry VIII c. 12) was passed, a law that made a clear distinction between those physically unable to work, who were given licenses to beg, and the able-bodied poor, who were not. ${ }^{52}$ In addition, any man judged guilty of vagabondage was to be "tied to the end of a cart naked and be beaten with whips" before being sent back to his birthplace for a period of three years, "and there put himself to labour like as a true man oweth to do." ${ }^{53}$ Soon after this act, the Dissolution of the Monasteries during the reign of Henry VIII made the passing of yet more legislation necessary in 1536. For Punishment of Sturdy Vagabonds and Beggars (27 Henry VIII c.25) again reiterated the distinction between those who could not and would not work. More importantly, with the

\footnotetext{
${ }^{49}$ Thomas Starkey, A Dialogue between Reginald Pole and Thomas Lupset (London: Chatto and Windus, 1948); William Marshall, Draft of a Poor Law (London, 1536); both authors quoted and discussed in Slack, 7.

${ }^{50}$ Starkey, 89; Slack, 7.

${ }^{51}$ Slack, 7; Linda Woodbridge, Vagrancy, Homelessness, and English Renaissance Literature (Urbana, Illinois: University of Illinois Press, 2001), 157.

${ }^{52}$ Tate, 190; Slack, 51.

53"Beggars Act of 1531" in Tudor Constitutional Documents, A.D. 1485-1603, ed. J. R. Tanner (New York: Cambridge University Press, 1922), 477; Slack, 51.
} 
government's re-appropriation of church lands, the medieval system of poor relief had forever been changed: because of the loss of monasteries as a source of poor relief, which had made up an important part of the medieval system of caring for the poor, the responsibility now fell solely on the parish. ${ }^{54}$ This was an important developmental step, as the parish was to remain the entity officially in charge of poor relief for nearly three centuries, until the passage of the New Poor Law in 1834. In addition, voluntary alms for the impotent poor were to be collected every week at the parish level and accounted for by either churchwardens or two other individuals judged suitable for the task. ${ }^{55}$

The process having become more complex due to the chaos associated with England's religious vacillations during the Protestant Reformation, various additional acts were passed during the reigns of Edward VI and Mary I. In the reign of the former, For the Punishments of Vagabonds and Relief of the Poor and Impotent Persons (1 Edw. VI c.3) was passed in 1547 decreeing branding and slavery as punishments for habitual vagrancy. ${ }^{56}$ Begging was now prohibited for the impotent poor, whose sole support came from weekly parish alms collections. Work was to be provided for the elderly, or impotent, poor, the children of beggars could be removed from their families and put to service, and any vagabonds refusing to work were to suffer enslavement as punishment. ${ }^{57}$ In 1550 , this unpopular act was repealed and begging was again allowed by license for the impotent poor. Even though this was subsequently reversed in a

\footnotetext{
${ }^{54} \mathrm{McIntosh}$ argues for this reason that it is the mid-sixteenth century that sees the true "birth" of the Elizabethan Poor Law. McIntosh, 2. On the general importance of the 1536 law, see also: Slack, 51; Tate, $190-1$.

${ }^{55}$ Slack, 51.

${ }^{56}$ Tate, 191; Slack, 51.

${ }^{57}$ Rose-Marie Crossan, Poverty and Welfare in Guernsey, 1560-2015 (Woodbridge, Suffolk: The Boydell Press, 2015), 52; Slack, 51.
} 
1552 statute, licensed begging was reinstated yet again in 1555 under Mary I, when pauper badges were instituted as a part of licensing. ${ }^{58}$

It is the reign of Elizabeth I that is associated with the most significant and enduring poor law legislation; nevertheless, the lead up to the all-important year of 1601, which marked the passage of the Elizabethan Poor Law, was gradual. In 1572, For the Punishment of Vagabonds and for Relief of the Poor and Impotent (14 Eliz. I c. 5) prohibited the granting of begging licenses, with the qualification that justices of the peace might license them in cases where too many might be seeking relief and stretching parish resources. ${ }^{59}$ The government continued to suggest harsh punishments for vagabondage. ${ }^{60}$ This particular statute is also significant because it created the office of overseer of the poor. ${ }^{61}$ Nonetheless, it was not until the 1598 passage of For the Relief of the Poor (39 Eliz. I c. 3) that the selection process of overseers would be outlined and their duties more completely defined. This statute also stipulated the collecting of poor rates - effectively a tax - from all parish inhabitants, a system unique in early modern Europe for its funding through taxation. ${ }^{62}$ As well, this mandated involuntary maintenance stood in contrast to the charitable and self-assessed collection of alms that had previously been standard and shaped a new communal financial stake in defining membership in the parish. ${ }^{63}$

\footnotetext{
${ }^{58}$ These acts were For the Provision and Relief of the Poor (5 \& 6 Edw. VI c. 2) and For the Relief of the Poor (2 \& 3 Philip \& Mary c. 5) respectively. Slack, 52.

${ }^{59}$ Tate, 191; Slack, 52.

${ }^{60}$ The 1572 act called for vagabonds to be whipped and burned in the ear, for example. In 1598, For the Punishment of Rogues, Vagabonds and Sturdy Beggars (39 Eliz. I c. 4) also stipulated that they could be whipped, and "incorrigible rogues" could be banished or sent to prison. Slack, 52, 53.

${ }^{61}$ Slack, 52.

${ }^{62}$ Punishments for nonpayment, which were outlined in 1601, could be harsh. As McIntosh reports, if a resident refused to pay his or her assessed amount, the parish overseers could seize by warrant the individual's money, goods, or livestock. If they were unable to procure the funds by these means, the individual could be thrown in prison. Hindle, On the Parish, 11; McIntosh, 280-1; Slack, 5; Tate, 191.

${ }^{63} \mathrm{McIntosh}$, however, argues that too much should not be made of the new compulsory system and maintains that voluntary and involuntary relief were not necessarily in opposition: "Catholicism imposed considerable pressure to contribute, long before the introduction of fully obligatory payments, and both kinds of
} 
Still, it has been For the Relief of the Poor (43 Eliz. I c.2), or the so-called Elizabethan

Poor Law of 1601, that has come down in history as the most sweeping and significant poor law legislation enacted in England during the early modern period. ${ }^{64}$ This new law — one that was originally intended to be temporary — underpinned all future seventeenth- and eighteenthcentury poor law legislation and was not substantially changed until $1834 .^{65}$ The 1601 law largely repeated the stipulations contained within the 1598 act, including the setting up of overseers of the poor and associated poor rate collection, but the law was important for providing new impetus for the realization of a parish-based system of poor relief. ${ }^{66}$ In this way, the two statutes worked in cooperation. Furthermore, both reiterated that the parochial system of relief should intervene in cases where a pauper's own family, the first recourse in relieving poverty, lacked the resources to contribute to his or her relief. ${ }^{67}$ Thus, implicit in late sixteenth- and early seventeenth-century legislation was the principle that parochial relief stepped in when familial support was not possible.

assistance expanded during the second half of the sixteenth century in an effort to meet mounting demand. Likewise, the categories of private and public support . . often blurred in practice . . " McIntosh, 296.

${ }^{64}$ The Elizabethan Poor Law later earned the appellation of the "Old" Poor Law after the passage of the "New" one in 1834.

${ }^{65}$ Tate, who dubs the Elizabethan Poor Law "the poor law par excellence" notes that it officially became permanent in 1640. Despite this, scholars have long recognized that the development of the government's poor relief policy was long in the making. For instance, as early as the eighteenth century, Richard Burn wrote that the 43 Elizabeth "was not a sudden unpremeditated project of queen Elizabeth's ministers, but had been the work of ages before, dictated by necessity and experience." Richard Burn, The History of the Poor Laws with Observations (London: H. Woodfall and W. Strahan, 1764; reprint, Clifton, New Jersey: Augustus Kelley Publishers, 1973), 104; Tate, 191.

${ }^{66}$ Again, this development can be envisioned as part of the growth of the early modern state, with Slack noting that "widespread implementation of the law came only after 1601, helped by pressure from the centre, through Assize judges lecturing magistrates who in turn used constables to stir a parish response." Slack, 18; Tate, 191.

${ }^{67}$ While reliance on one's family for support was set down by English law, it was not mandatory in either the Netherlands or Germanic countries. Though, as Fontaine argues, this might be because the practice of familial maintenance was widespread enough so as not to require legislation. Marvin B. Sussman, "Law and Legal Systems: The Family Connection," in Family and Support Systems across the Life Span, ed. Suzanne K. Steinmetz (New York: Plenum Press, 1988), 26; Laurence Fontaine, The Moral Economy: Poverty, Credit, and Trust in Early Modern Europe (New York: Cambridge University Press, 2014), 26-27. 
In terms of settlement and removal, two principles that formed the foundation of poor law administration in the second half of the seventeenth century, it is actually For the Better Relief of the Poor of this Kingdom (13 \& 14 Car. II c. 12) that is far more significant. ${ }^{68}$ This act, which was passed in 1662, is sometimes referred to as the Act of Settlement. In fact, it is not hyperbolic to consider it the most important piece of poor law legislation between the years 1601 and $1834{ }^{69}$ Prior to 1662 , the only statutes mentioning residency requirements in regards to settlement were those relating to vagrancy, which continued to be an issue of great concern. The usual aim of such anti-vagrancy stipulations had been the return vagrants to their parishes of birth. $^{70}$ Nevertheless, the issue of what exactly made up "settlement" remained vague even in the 1598 law, and the main judicial interpretation was simply that the impotent poor should receive relief, while vagrants were to be removed. ${ }^{71}$

What the 1662 act consequently succeeded in doing was removing some of this ambiguity and defining more clearly two important points. The first was outlining where the poor were permitted to receive relief. The second was specifying how parish officials were to determine a pauper's proper place of settlement and resultant eligibility for relief. ${ }^{72}$ In short, the new law introduced the important concept that all persons had a parish of settlement - that is, an official place of residence - to which they could eventually be removed in the event of "turning" vagrant. $^{73}$

\footnotetext{
${ }^{68}$ Slack, 54.

${ }^{69}$ Tate, 191.

${ }^{70}$ Hindle, On the Parish, 306.

${ }^{72}$ Tate, 192; McIntosh, 274.

${ }^{73}$ Slack, 28.
}

${ }^{71}$ Hindle follows this point with a discussion of how there seems to have been much local variation in poor law administration owing to the somewhat nebulous nature of pre-1662 legislation. Hindle, On the Parish, 307 , 311-25. 
Eventually and as spelled out in law, by around 1700 settlement could be gained via several means. For an illegitimate child, birth conferred settlement before 1834. Marriage did the same for women, who were afterwards settled in their husbands' parishes. Other ways of gaining settlement included serving in public office within the parish, the payment of parish poor rates, renting property with an annual value greater than $£ 10$, one year's service for an unmarried person, serving an indentured apprenticeship, residing in the parish for forty days, and owning land within the parish. If none of these criteria applied, then paternal settlement formed the basis. One's most recent place of settlement invalidated any earlier ones. It is also notable that the 1662 Act of Settlement gave parish officials the somewhat draconian power to remove any individual likely to become chargeable to the parish, which included anyone who had migrated into the parish in search of work:

Whereas the necessity number and continual increase of the Poore not onely within the Cities of London and Westminster with the Liberties of each of them but alsoe through the whole Kingdome of England and Dominion of Wales is very great and exceeding burthensome being occasioned ... by reason of some defects in the Law poore people are not restrained from going from one Parish to another and therefore doe endeavor to settle themselves in those Parishes where there is the best Stocke the largest Commons or Wastes to build Cottages and the most Woods for them to burn and destroy and when they have consumed it then to another Parish and att last become Rogues and Vagabonds to the great discouragem[en]t. of Parishes to provide Stocks where it is lyable to be devoured by Strangers Be it therefore enacted by the Authority aforesaid That it shall and may be lawfull upon complaint made by the Churchwardens or Overseers of the Poore of any Parish to any Justice of Peace within Forty dayes after any such Person or Persons coming so to settle as aforesaid in any Tenement under the yearely value of Ten pounds for any two Justices of the Peace whereof one to be of the Quoß of the Division where any person or persons that are likely to be chargeable to the Parish shall come to inhabitt by theire warrant to remove and convey such person or persons to such Parish where he or they were last legally setled either as a native Householder Sojourner Apprentice or Servant for the 
space of forty dayes at the least unlesse he or they give sufficient security for the discharge of the said Parish to bee allowed by the said Justices[.] ${ }^{74}$

It was not until 1795 that it was specified that only those actually chargeable to the parish could be removed. $^{75}$ This effectively meant that before 1795 , anyone deemed probable to seek relief could be removed to their parish of settlement, a factor that gave local officials much freedom in their interpretation of the law.

The last important shift in poor relief prior to 1834 developed between the 1690 s and 1780s, when focus moved away from the itinerant able-bodied poor, who had become less of a problem than they had been in the late sixteenth and earlier seventeenth centuries. ${ }^{76}$ In this period, attention turned to the settled poor. Now, the poor neighbor, in addition to the poor stranger, was regarded as suspect, and the chief issue centered on how to discourage such people from becoming chargeable to the parish. ${ }^{77}$ Various tactics were consequently tried in an attempt to simultaneously create work and deter the parish poor from seeking relief. For example, after the passage of For Supplying Some Defects in the Laws for the Relief of the Poor (8 \& 9 William III c.30) in 1697, any employer who refused to take on a pauper apprentice could be fined. The high burden for the parish continued when it was decreed that in areas where wages were low, a

\footnotetext{
74"Charles II, 1662: An Act for the better Releife of the Poore of this Kingdom," in Statutes of the Realm: Volume 5, 1628-80, ed. John Raithby (Great Britain Record Commission, 1819), 401-5, British History Online, accessed 16 August 2016, http://www.british-history.ac.uk/statutes-realm/vol5/pp401-405.

${ }^{75}$ Although some evidence indicates that the parish continued to play a large role in distributing charity to the poor, by and large the New Poor Law of 1834, which marked the further centralization of poor relief through Poor Law Unions and the infamous workhouse, signaled the end to the earlier parochial system of relief. Tate in fact considers the New Poor Law as marking "the strangulation of the parish." It is, however, perhaps also worth noting that even the new law did not make substantial changes to settlement. Snell, Parish and Belonging, 85-6, 339-40; Tate, 11, 199.

${ }^{76}$ For the most part, this was due to the fact that by late seventeenth and eighteenth centuries, economic conditions had improved over those in the sixteenth and earlier seventeenth centuries.

${ }^{77}$ Brodie Waddell outlines a sharper attitude to poor strangers in the latter half of the seventeenth century, mentioning that Gough "devoted a lengthy appendix to documenting the many attempts by local communities to exclude paupers who they regarded as 'foreign'" Brodie Waddell, God, Duty and Community in English Economic Life, 1660-1720 (Rochester, New York: The Boydell Press, 2012), 191.
} 
condition that was usually the result of labor surpluses, parishes had to make up the difference in pay in allowances.

Another part of the above 1697 legislation, and the general program of deterrence, was that those seeking relief were required to wear pauper badges, in addition to all members of their families. ${ }^{78}$ The badging of not just the male householder but also his entire family, "powerfully insisted upon the notion that idleness was an inherited condition, propagated by feckless parents who lacked the moral compass to inculcate habits of industry and discipline in their offspring." ${ }^{79}$ In some ways, this is not a new development and can be seen as a return to the medieval licensing of beggars. In an eighteenth-century study of England's poor laws, Richard Burn postulates that pauper badging possibly had its origins in the medieval livery of household retainers, and was thus "feudal." ${ }^{80}$ However, one function of the re-instituting of pauper badges in the late seventeenth century was undoubtedly to shame the poor and discourage them from seeking relief. It is therefore more likely that the statute had its roots in the earlier medieval badging of various types of "deviants," such as Jews, lepers, and prostitutes. ${ }^{81}$ The growing unsympathetic attitude in the late seventeenth century not only toward the migrant poor, but also to the settled poor of the parish perhaps built upon the established foundation of earlier medieval views. $^{82}$

\footnotetext{
${ }^{78}$ Hindle, On the Parish, 433; Slack, 31-2, 54.

${ }^{79}$ Hindle, "Dependency," 10.

${ }^{80}$ Burn, 119.

${ }^{81}$ The medieval "othering" of such groups is the key focus of R. I. Moore's The Formation of a Persecuting Society: Authority and Deviance in Western Europe, 950-1250, 2nd ed. (Malden, Massachusetts: Blackwell Publishing, 2007).

${ }^{82}$ Michael Mollat for example terms them "badges of infamy." Michel Mollat, The Poor in the Middle Ages: An Essay in Social History, trans. Arthur Goldhammer (New Haven, Connecticut: Yale University Press, 1986), 291; Beier, 154; McIntosh, 297.
} 
Even so, it is important to not view badging as a solely top-down development and take into account the persecuted as well as the persecutors. For the poor themselves, badging was a complicated matter, for on the one hand badging helped distinguish between the deserving poor, who received badges, and the undeserving poor, who did not. So, in one sense to be badged was to belong. But, by the end of the sixteenth century attitudes had shifted such that badges evolved from identifying "the respectable poor" to instead marking out the parish's "dependent poor" and thus came to be more directly associated with shame. ${ }^{83}$ Steve Hindle points out that by the end of the seventeenth century all paupers were to be badged, and although enforcement was uneven and has proved difficult to measure, the canvas was symbolically marked with both the initial "P" for pauper and the first letter of the individual's parish of settlement. ${ }^{84}$ What had denoted membership had become more redolent of ownership. In a very fundamental and significant way, the relationship between society and the poor had transformed from an association based on mutuality and reciprocity to one that was marked instead by segregation. ${ }^{85}$ Seen in this light, the definition of the "acceptable" types of poverty had significantly narrowed.

However, there were several competing narratives concerning the poor. For example, care must be taken to not confuse attitudes to the poor, as contrasted with the relative respect for the voluntary poverty of the Middle Ages and which seemed to harden fairly quickly, relatively speaking, with attitudes about wealth and accumulation, which appear to have evolved more gradually and vexed the entire early modern period. ${ }^{86}$ Moreover, although a spirit of Christian brotherhood and inclusivity abounded in sermons throughout the seventeenth and eighteenth

\footnotetext{
${ }^{83}$ Hindle summarizes that badges "at the same time implied both belonging to, and yet paradoxically also exclusion from, the local community." Hindle, "Dependency," 6, 8.

${ }^{84}$ Hindle, "Dependency", 6, 8.

${ }^{85}$ John Bossy, Christianity in the West, 1400-1700 (New York: Oxford University Press, 1985), 146, 148.

${ }^{86}$ Waddell, 82-83.
} 
centuries, this coexisted with "the symbolic expulsion of particular people from the bosom of human society." ${ }^{87}$ Those frequently dubbed as "inhuman" included the inhospitable, miserly, and economically predatory, as well as - at the other end of the social spectrum - the parasitical itinerant poor, who were described in terms of "ravaging vermin or blood-sucking insects." 88 This complex and often contradictory rhetoric is the cultural script from which Gough writes.

\section{Settlement in The History of Myddle}

As a parish official for Myddle and a generally respected individual within the community, Richard Gough is able to provide an insider's view into the workings of late seventeenth- and early eighteenth- century poor law administration within the parish. In addition, his own family had had a fairly long period of residency within the parish, which dated back to the earlier half of the sixteenth century, when his ancestor, also named Richard Gough, came to reside at Newton on the Hill in 1539 from nearby Tilley. ${ }^{89}$ As a result of his close involvement in parish affairs, along with his family's relative permanence in Myddle, Gough is able to speak with some authority on matters of local history. However, what this also means is that these factors simultaneously affect his assessment of Myddle's poor.

Within The History of Myddle Gough describes eight distinct disputes involving Myddle and various parishes that deal with the issue of settlement. In terms of Gough's role as an official within the parish, the narrative is certainly written from his own biased perspective. However, when checked against quarter sessions records for Shropshire, the details Gough provides seem to have been mostly truthful in terms of dates and the broad outline of the cases. This means that his narrative represents a fairly accurate catalogue of the inter-parochial settlement cases

\footnotetext{
${ }^{87}$ Waddell, 153-54.

${ }^{88}$ Waddell, 154-57.

${ }^{89}$ Gough, 153.
} 
occurring between 1668 and 1701, the period which the settlement cases he discusses span. It also shows the effect various pieces of poor law legislation had at the local level, most notably the Elizabeth Poor Law of 1601, which placed the parish at the center of poor law administration and those statutes dealing with settlement.

However, in two instances Gough mentions cases that do not appear in the quarter sessions records. The first of these is the eighth case between the parish of Myddle and the settlement of Hadnall, which can be dated to sometime after $1701 .{ }^{90}$ That this case should not appear in quarter sessions records is perhaps not surprising, because it was fundamentally an intra-parish matter. The matter concerned the establishment of Gough's uncle's apprenticeship charity, which had been set up in $1669 .{ }^{91}$ Disagreement arose when representatives of the chapelry of Hadnall requested that several of Hadnall's resident children be set out as apprentices through William Gough's charity. ${ }^{92}$ Gough writes that he refused this "for severall reasons." 93 Gough, along with the other churchwardens for Myddle, were then summoned to the town of Shawbury. There, Gough argued that although Hadnall was technically within the parish of Myddle, it was commonly known that "Myddle parish was divided into two parts. ... [and t]hat these maintaine theire poore, distinct one from the other; that is one Parish as to the Church, but two Parishes as to the Poore ..."94 Moreover, Gough maintained that his uncle "was borne in that part of the Parish which is out of the libertyes of Shrewsbury, and it is more than likely that

\footnotetext{
${ }^{90}$ The reckoning of this tentative date stems from the dating of the previous case involving Nicholas Hampton, discussed below, which quarter sessions records show as having occurred in 1700-1701.

${ }^{91}$ Gough, 332 n. 20.

${ }^{92}$ A chapelry was a subdivision of the parish church. Chapelries were usually established to prevent parish residents from having to travel a long way for worship services. Hadnall was a small village about five miles to Myddle's southeast.

${ }^{93}$ Gough, 261.

${ }^{94}$ Gough, 262.
} 
hee left this legacy for the good of the poore of the place where hee was borne." 95 Eventually, it seems that the case was dropped by Hadnall. Gough remarks that Myddle could have perhaps sued Hadnall for costs, but that they did not want to anger Hadnall's representative, Francis Berkely. Since Berkely was a justice of the peace, they "feared it might shorten his kindnesse to us in other matters." 96

With regard to the cases Gough chooses to write about, this case is unique in that it is not between Myddle and another parish. Nor does it deal with an individual whose settlement is in question. Instead, the case revolves around responsibility for poor relief within the parish itself. In this case, the reasoning against apprenticing out Hadnall's children was based on geography and administrative division, and features anxieties about parish finances and local politics. One implication for Myddle was that taking on the support of pauper children from Hadnall would have been a substantial financial burden. In order to deal with the problem of pauper children, decisions had to be made about those deserving and undeserving of relief, in order for the parish to attempt to deal with the problem of poverty in a manageable way. In fact, bequests like William Gough's were frequently motivated not necessarily by charity so much as to help alleviate the financial burden the poor laws produced for the parish. ${ }^{97}$ Seen this way, William Gough's charity was perhaps guided more by concern for local ratepayers than the poor themselves. Moreover, Gough's emphasis on William Gough's likely intention to benefit the people living in his place of birth through his charity reveals a sense of his uncle's belonging there. At the same time, it underscores the importance of one's place of birth as a "head," or

\footnotetext{
${ }^{95}$ Gough, 263.

${ }^{96}$ Gough, 264.

${ }^{97}$ Hindle, On the Parish, 291.
} 
creator, of settlement as laid out in the poor laws, exhibiting an additional point of connection between the national and local.

The second instance that does not appear in quarter sessions records is Gough's third case, which Myddle's parish chest records indicate occurred in $1694 .{ }^{98}$ This particular disagreement was between the parishes of Myddle and Preston Gubbals over the maintenance agreement between one Andrew Weston and his son-in-law, Thomas Williams. ${ }^{99}$ According to Gough, this was a complicated case and involved Gough himself, who acted on behalf of Myddle. The exact length of Weston's residence in Myddle is not specifically mentioned: Gough indicates only that he had resided at Marton and rented property worth more than $£ 10$ per annum from a Mr. Thomas Harwood. ${ }^{100}$ After his wife had died, Weston gave Williams his goods and chattels in return for him maintaining him for the remainder of his life. Trouble began, however, when Weston's daughter died and Weston himself became blind, exemplifying the "downward mobility" in living standards that advanced age often initiated. ${ }^{101}$ At this point, Williams sought an order from officials in Preston Gubbals to remove Weston to Myddle.

Where the disagreement between Myddle and Hadnall revolved around differing conceptions of administrative divisions, coupled with the question of where responsibility to the parish's poor children rested, this case instead hinged on the definition of family. As indicated, one principle that had been inherent in poor law legislation since the Tudor period was that before an individual turned to the parish for relief, support should be sought from one's relations. Thus, Myddle's counsel, who was none other than the above-mentioned Francis Berkely, whom

\footnotetext{
${ }^{98}$ Myddle Parish (Shropshire), Removal Orders, 1683-1792, P201/L/5 (Shropshire Archives, Shrewsbury).

${ }^{99}$ Gough, 253-55.

${ }^{100}$ Gough, 253-54.

${ }^{101}$ Susannah Ottaway, The Decline of Life: Old Age in Eighteenth-Century England (New York: Cambridge University Press, 2004), 180.
} 
Gough and his associates had been so afraid of offending in the Hadnall case, argued that although the 1601 poor law did not specify relatives by marriage, they were nonetheless responsible for the relief of their poorer relatives, even if the relationship was not by blood. Gough writes:

Mr. Berkely insisted upon the Statute of the $43^{\text {rd }}$ of the Queene, cap. 2, whereby it is enacted that the grandfathers, grandmothers, fathers, mothers and children of any poore, lame, blind, \&c., beeing of sufficient ability, shall make such allowance for the maintenance of such poore, \&c., as the Justices of the Quarter Sessions shall allow. Here says Mr. Berkely, the grandfather-in-law, the grandmother-in-law, the father-in-law, the mother-in-law, the son-in-law, the daughter-in-law, though they bee not named in the Statute yet by the equity of the Statute they are obliged ... ${ }^{102}$

Although he did not dispute the above premise itself, Mr. Atkis, the representative for Preson Gubbals, argued his case on a different basis. According to Atkis, Williams was not responsible for Weston's care because Williams himself was "a poore man," and the law specified that only those family members with means were responsible for supporting their poorer family members. ${ }^{103}$ Although not a blood relative, Williams's predicament illustrates very well one of the chief difficulties for the relatives of the impotent poor: that although they were the first defense in taking care of poorer relations, all too frequently they themselves were too underprivileged to be able to do so. ${ }^{104}$ This case thus exposes how family obligation sometimes overlapped with and further complicated poor law administration, a process often given incentive by a parish's desire to safeguard its financial resources, as Myddle's surviving documentation shows. It also indicates one of the ways in which the poor law could be contested and reveals how in reality, implementation of the poor law was not simple. Ultimately, the

\footnotetext{
${ }^{102}$ Gough, 254.

${ }^{103}$ Gough, 254.

${ }^{104}$ Ottaway, 155.
} 
system was a flexible one, and settlement depended on a number of criteria. Consequently, each individual's situation had to be evaluated on a case-by-case basis, something which is born out in the various cases appearing within The History of Myddle.

Ultimately, the matter ended with Weston's settlement judged as being in Myddle, but Williams was still required to pay for his maintenance. The justices of the peace disagreed with Atkis's contention that Williams was too poor to contribute to Weston's relief. Instead, they judged that Williams was "a p[er]son of ability fitt to mainetaine or contribute to the maintenance of his said Father in Law" and ordered him to remit 2s per week to Myddle for this purpose. ${ }^{105}$ Despite this, Gough voices that he was dissatisfied that Williams was not required to pay costs, and so after the case was over, representatives from Myddle sent for Williams. After threatening to sue him, they managed to induce Williams to agree to pay one half crown per week for as long as his father-in-law had resided in Myddle, and to take him back with him to the parish of Preston Gubbals to live with him at his residence at Merrington. ${ }^{106}$ Although there was tremendous local variation, parish expenditure could range anywhere from $2 \mathrm{~s}$, the amount ordered by the court to be paid to Myddle for Andrew Weston's maintenance, to just over 8s per head of population and consisted of regular disbursements along with "targeted occasional payments" in times of distress. ${ }^{107}$ Parish support of a pauper frequently took in the maintenance of his or her entire family, and could include the apprenticing of a family's children, for example. While Myddle's records of expenditure in this regard are not extant, it is easy to see how high the financial stakes could be for a parish.

\footnotetext{
${ }^{105}$ Removal Orders, 1683-1792, P201/L/5 (Shropshire Archives, Shrewsbury).

${ }^{106}$ It appears that though individuals could be "taxed" for a parish's support of a relation, they could not be made to house them; moreover, the Weston case is perhaps a distinctive one, as it seems that this law was rarely enforced. Gough, 255; Ottaway, 175.

${ }^{107}$ Hindle, On the Parish, 287-88, 296.
} 
Still, parish officials and wider society seem to have considered elderly paupers one of the most deserving types of parish poor, and poor law regulations concerning the impotent poor that is, the aged and infirm - were among its most undisputed regulations. ${ }^{108}$ Seen in this light, one could speculate that the motivation of Myddle's parish officials was to secure Weston the best support possible under the desperate circumstances in which he found himself. Perhaps they also wished to force his son-in-law to hold up his original maintenance agreement, and thus his familial and moral obligations.

At the same time, this case is also a very clear example of how, despite their own agency in claiming relief as a right and officials' predispositions to look favorably upon them, the elderly poor were very much dependent on the caprices of local elites. ${ }^{109}$ Likewise, the Weston case reveals how fiscal concerns often trumped any ethical concern for the plight of individual paupers within the world of poor law administration. Williams's maintenance bond, freeing the parish of Myddle "of and from all troubles costs charges paym[en]ts \& expences which shall or may happen for us towards the menteinance and releife or by reason of any $\operatorname{pr}[\mathrm{e}]$ tended set[t]lem[en]ts" of the aged Weston, shows how eager parish officials could be in exempting the parish from support of a pauper. ${ }^{110}$ Indeed, that the bond, which is signed by Gough, survives is testament to how important it was for Myddle to document that the parish was no longer held responsible for Weston's support. As well, the language within the document, referring to any future, "pretended," claim to Weston's settlement in Myddle, makes apparent that Myddle's parish officials regarded such an assertion fraudulent.

\footnotetext{
${ }^{108}$ Ottaway discusses at length the possible reasons why this was so. Ottaway, 173, 176-82.

${ }^{109}$ Ottaway, 182-83.

${ }^{110}$ Myddle Parish (Shropshire), Maintenance Bonds, 1671-1771, P201/L/11 (Shropshire Archives, Shrewsbury).
} 
Gough's commentary reaffirms many of these ideas. As he does elsewhere in his writings, Gough fails to assess the individuals involved in this case with any palpable interest in their individual troubles. Nor, for that matter, is he sympathetic to Williams's purported financial difficulties. Furthermore, Gough seems to regard the removal of the widowed, blind, and elderly Weston as a great victory for Myddle and appears to relish the part that he personally played in the end result. He insists that Myddle should have been paid costs, and writes that although they did not press the issue while at court, Myddle's officials were eventually able to negotiate a reimbursement out of Williams after their meeting with him. ${ }^{111}$

As with the Hadnall dispute, the bottom line appears to have been the most important consideration, echoing the sentiments of the eighteenth-century lawyer, Roger North, who writing on the poor laws disparages that:

No Town willingly receives a Poor Man, though they want poor people to do the ordinary Works of Husbandry, because they say his Family may become a Charge to the Parish. And if one, that is not legally settled, happen to be sick or near Labour, they will hoist them up, in this carted Pilgrimage, without allowing them any Repose, and, if it be Midnight, hurry them to the next Town, and there shoot them down like Dirt; and they find there as little Comfort as they left behind. ${ }^{112}$

Informed by North's comments, it is not hard to view Weston in such a way, as a passive agent, passed from parish to parish. Perhaps Weston regarded Williams's being made to pay for his maintenance, to which he had purportedly previously agreed, as a success. However, though his son-in-law now legally owed him support, it is not clear whether Williams could actually afford to do so. Moreover, although at first Weston was to remain in Myddle, with Williams merely reimbursing the parish for his maintenance, Myddle pressed for his removal, and in the end

\footnotetext{
${ }^{111}$ Gough, 255.

${ }^{112}$ Roger North, A Discourse of the Poor, Shewing the Pernicious Tendency of the Laws now in Force for Their Maintenance and Settlement (London, 1753), 25.
} 
Weston was to live with his son-in-law, who was likely hostile to him given the circumstances, in another parish.

The last discrepancy in Gough's narrative concerns his omission of a case heard at the April quarter sessions in 1692 involving a dispute between Myddle and the parish of High Ercall over the settlement of an Elinor Scott. As part of the judgment in the case, it was decided that Scott was to be removed to Myddle. ${ }^{113}$ Perhaps Gough fails to mention the case because he was not personally involved in it and therefore not familiar with its particulars. Or, since Myddle lost the case, maybe he was reluctant to discuss it, choosing to write his history in a way favorable to the parish's successes and not failures. It is also possible that, for whatever reason, he did not find the case interesting enough to include in his history. Another alternative is that it simply escaped his mind. It is not easy to know.

The remaining six cases in Gough's history are ones that can be substantiated in the Shropshire quarter sessions records, and occasionally in Myddle's own parish chest records. The first case appearing in the History of Myddle is also the first of several involving the Beddow family, a family of whom Gough is highly critical. The initial case relates to Humphrey Beddow, an individual whose penury is well documented in the 1672 Shropshire hearth tax, on which he appears on the list of paupers deemed exempt from taxation. ${ }^{114}$ In the initial disagreement, the parishes involved were Myddle and Cardington. The matter of Beddow's settlement was taken up at both the January 1667/8 and Easter 1668 quarter sessions.

\footnotetext{
${ }^{113}$ No other details are supplied, with the abstract merely reading: ". . Elinor Scott to be removed from High Ercall to Middle. . ." Robert Lloyd Kenyon, ed., Orders of the Shropshire Quarter Sessions, vol. 1 (16381708) (Shrewsbury: Shropshire County Council, 1902), 140. Hey notes the absence of this case also. See: Gough, 332 n. 7.

${ }^{114}$ Shropshire Archaeological and Parish Register Society, The Shropshire Hearth Tax Roll of 1672: Being a List of the Householders in the County (Shrewsbury, Shropshire: n.p., 1949), 205, Family History Library (FHL) microfilm 453,027, item 1 (FHL, Salt Lake City, Utah).
} 
Cardington put forward the suggestion that Beddow had acquired a possible settlement in the parish of Church Stretton. As a result, it was recorded in the January 1667/8 quarter sessions that the matter was to be taken up again at the Easter quarter sessions, in order that officers from Church Stretton attend. What became of this is not mentioned, with the Easter records merely recording that Beddow's settlement was determined to be in Myddle, owing to him "having married his wife there without any disturbance by the officers of Myddle." 115

It seems that Beddow, like most of the rural poor in this period, had lived out a fairly itinerant existence. Gough reports that Beddow had been both born and set an apprentice to a shoemaker in Cardington, after which time he migrated to Myddle in order to find "journey worke" and while there, married Mary Davies from "Haremeare Hill [Harmer Hill]."116 Eventually, Myddle's parish officers lodged a complaint against Beddow to Francis Thornes, a justice of the peace for Shropshire. After this, a warrant was issued to George Cranage, a constable within the parish.

Apparently, at around same this time Beddow fell ill and promised that he would return to Cardington once he recovered. Gough writes that Beddow's convalescence was long and that although his illness "took not away his life yet it tooke away his worke, for I never knew him worke afterward butt was an idle beggar all his life after." ${ }^{117}$ Nevertheless, Beddow eventually returned to Cardington, whose officials then promptly sent him back to Myddle. Myddle decided to appeal the order, but lost the case. Beddow's settlement in Myddle was determined on the basis of his residing in Myddle for more than forty days without interruption, despite Myddle's

\footnotetext{
${ }^{115}$ This refers to the forty-day residency requirement that conferred settlement on an individual and means that the officials judged that Beddow's residency had been uninterrupted. Orders of the Shropshire Quarter Sessions, 100-1. Gough, 251.

${ }^{116}$ By "Haremeare Hill" Gough means Harmer Hill, a settlement about two miles southeast of Myddle.

${ }^{117}$ Gough, 251.
} 
contention that a complaint from within the parish, which had since been lost, had been brought against him. Gough is philosophical, and simultaneously competitive, about the defeat: "This is the first contest that we had and thus wee lost it; but thanks be to God wee never lost any afterwards." ${ }^{118}$ It seems Beddow remained in Myddle, as parish registers record that a "Hump. Bedowe" was buried there 19 July $1690 .^{119}$

This case highlights a recurring theme: for men, one's place of employment as well as the terms of one's hiring contract were important factors in establishing settlement. Again, this was because either an apprenticeship or one-year's service bestowed settlement within the parish of employment. In this case, both from the point of view of Myddle's parish officials and according to law, Beddow's place of birth and the parish where he served out his apprenticeship Cardington - mitigated Beddow's settlement in Myddle. A complaint was eventually brought by the parish officers to a justice of the peace, when the likelihood of Beddow seeking relief became the paramount concern. As always, the fiscal burden of poor relief was an ever-present apprehension for parish officials.

Beddow's case also illustrates that gender influenced how officials determined one's settlement. Although marriage conferred settlement for a woman into her husband's parish, this did not work both ways. Therefore, Beddow's marriage, although it was to a resident of Myddle, did not grant him settlement there. The marriage was still an impetus for Beddow's settlement dispute, however, in the sense that after the couple were wed he settled in Myddle, coming to the attention of local officials as one likely to become chargeable. As for Cardington's

\footnotetext{
${ }^{118}$ Gough's comments here are somewhat perplexing, in that quarter sessions records show that Beddow's case was not the only case in which Myddle lost, as the above-mentioned 1692 case involving Elinor Scott proves. Gough, 252.

${ }^{119}$ W. P. W. Phillimore, ed., Registers of Myddle, Shropshire Parish Registers, Lichfield Diocese, vol. 19 ([Shropshire]: Shropshire Parish Register Society, 1931), 110.
} 
representatives, it was Beddow's residence in Myddle that was the point of significance, and they "alledged that hee had procured a settlement in Myddle parish by 40 days' residence and longer time." ${ }^{120}$ Gough writes that Myddle's delegation could not ultimately prove that Beddow's fortyday residency had been disturbed and therefore lost the case. In the end, Cardington's argument - that Beddow's unbroken forty-day residence in Myddle had gained him settlement there carried much more weight.

Gender also affected the moral judgments that were so often part of the implementation of the poor laws. Despite Gough's criticisms about Beddow's laziness, he blames the bad character of the Beddow children not on Beddow himself, but on their mother, Mary Davies, "who brought up her children in idlenesse, and favoured them in theire bad courses." ${ }^{121}$ Gough writes that Beddow's wife had in turn learned bad traits from her own mother, the disreputable local beggar Sina Davies. According to Gough, Davies was "a crafty, idle, dissembling woman, and did counterfeit herselfe to be lame, and went hopping with a staffe when men saw her, butt att other tymes could goe with it under her arme, as I myselfe have seene her, and shee had maintainance from the Parish many yeares before she dyed ..." ${ }^{122}$ Thus, bad mothers and wives were especially powerful corrupting influences, seemingly even more so than lazy, alcoholic fathers.

While it was a woman's moral influence that shaped the family, it was the father's labor that sustained it, and Beddow's case is also symbolic of a theme that runs throughout Gough's The History of Myddle. The idleness of the able-bodied poor was clearly a larger societal concern, and here Gough seems to be giving voice to wider cultural attitudes toward poverty,

\footnotetext{
${ }^{120}$ Gough, 252.

${ }^{121}$ Gough, 257.

${ }^{122}$ Gough, 258.
} 
anxieties that had subsisted since at least the fourteenth century. Gough criticizes Beddow for sinking into dependence and becoming an "idle beggar" after his illness, where beforehand he had been self-sufficient and able to support himself and his family through his work as a cobbler. $^{123}$

The second settlement case, which dates to 1669 and thus occurred not long after the Humphrey Beddow affair, concerned the abandoning of a child in Myddle. ${ }^{124}$ Gough reports that "a yong child" had been left during the night on the porch of Barnabas Holloway, who upon finding it, sought out one of Myddle's churchwardens along with Gough himself about the matter. ${ }^{125}$ After setting the child out to be nursed, the hunt began for evidence of the mother's identity. After finding out that a woman with an infant and a son aged about two or three had lodged in Myddle before abruptly disappearing by the morning, Gough and his companion, a Mr. Atcherley, went in separate directions to try and catch up with the woman. Gough then reports that he met up with his cousin, Anne Newans, who had heard about a poor woman who had recently given birth in the parish of Shawbury and then afterwards stayed at "Greensell [Grinshill?],"126 where the infant was christened, before she made for the general direction of Myddle.

Although Gough does not explicitly say why this piece of information about the infant's place of birth was significant, in terms of settlement, it was of the utmost importance. Birth within a given parish for an illegitimate child conferred settlement according to pre-1834 legislation. It was therefore imperative for Gough and the other churchwardens to ascertain the

\footnotetext{
${ }^{123}$ Gough, 251.

${ }^{124}$ Orders of the Shropshire Quarter Sessions, 106.

${ }^{125}$ Gough, 252.

${ }^{126}$ This location is probably Grinshill, which lies about four miles northwest of Shawbury.
} 
child's place of birth. It would be all the better if the birth could be proven to have taken place outside of Myddle, thus rendering another parish responsible for support of the child, who from all appearances was probably illegitimate and likely to become chargeable to the parish. Thus, financial concerns can be discerned as the main impetus for the informal investigation into the mother's whereabouts.

Gough's cousin had also divulged that clothes had been given to the woman while she was in Shawbury. The clothing turned out to be the crucial piece of evidence linking the poor woman who had traveled through Shawbury with the child left in Myddle. After inquiring at Grinshill and finding out more about the clothing, Gough was able to go back to Myddle and confirm that the child was indeed wrapped in clothing matching the "greene sey apron" given to the woman at Grinshill. ${ }^{127}$ When shown the material, Gwen Kay, the woman in Grinshill who had originally given the poor woman the cloth, was able to confirm that it matched that which she had given to the poor woman.

Myddle then contacted Shawbury's overseers of the poor and according to Gough, representatives from both parishes agreed to appear at the next quarter sessions at Easter $1669 .{ }^{128}$ The case ended up with the matter being decided in Myddle's favor, with Gough triumphantly writing:

Wee proved that a poore woman was delivered of a child in Shawbury Parish, and that shee had with her a lytle boy of about two or three yeares old in a whiteish coloured coate with ribbons about the wast of the coate. Wee proved that the same poore woman and her yong child and lytle boy came to Greensell, and that the woman att whose house shee was delivered in Shawbury Parish, came to visitt her while shee was att Greensell, and that shee was brought a bedd att her house. Wee proved by Guen Kay that shee gave that woman the peice of a greene sey

\footnotetext{
${ }^{127}$ Gough, 253.

${ }^{128}$ Orders of the Shropshire Quarter Sessions, 106.
} 
apron which was shewed in court; and wee proved that the child was wrapt in it when the child was found. ${ }^{129}$

Gough is at his best in describing this case: one can nearly imagine that with the assorted eyewitness testimony, not to mention the production of the green apron itself, which probably made for quite a dramatic pièce de résistance, that the case appeared quite damning for Shawbury. In fact, Gough reports that all Shawbury could do was attack the character of Holloway, the man upon whose porch the child had been left. In the end, Myddle triumphed and Shawbury's overseers of the poor were ordered "to receive and provide for" the child. ${ }^{130}$

Neither the child's nor the mother's names are recorded, by either Gough or in the quarter sessions records. Towards the end of his description of this case, Gough reports that the woman was eventually "found out" about three years later, perhaps indicating that her identity had been ascertained. ${ }^{131}$ However, he mentions no other details about her identity or individual situation but cautions that: "Nulla latent quae non tempus aperta facit [Nothing is hidden which time does not reveal]." ${ }^{132}$ But, although this lack of specifics is unfortunate, it is not unusual, for the apparently unmarried woman and her illegitimate child were immediately regarded as a potential drain on parish resources, hence the harried attempt to gather evidence and track the woman down. Moreover, the case seems to support the observations of historians such as Paul Slack, who find that it was most often "women and men with families - not young male employable labourers" who were most often removed from a parish. ${ }^{133}$

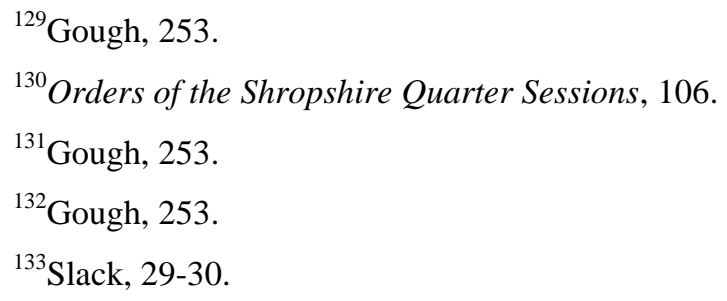


Though experiences among the individuals in these cases surely differed greatly, it is noteworthy that the one bond common to them all is itinerancy. ${ }^{134}$ Nevertheless, it is unusual in terms of The History of Myddle, as this case is only one of two mentioned concerning a woman and the only one to directly involve a child. In fact, this is probably part of the reason why there is such an otherwise dearth of detail. As a "stranger" to the parish, little would have been known about the woman in any case, but she is symbolic of the migrant, nomadic poor whose movements can only be traced through such poor law documents. Hers is a familiar story, and she is representative of those unlucky single women who found themselves pregnant, usually during their terms of service, and who occasionally materialize in sources of the period. Some of these vulnerable women would have been impregnated by their masters. ${ }^{135}$ Tellingly, most of them document the punishment of those who harbored the mothers of bastards:

Ejected from her place of employment, the pregnant woman might then move away to give birth in a parish where she was not known. Women heavy with child must have been common sights on the fringes of towns and villages, though most found shelter, at least a roof and a bed, by the time they went into labour. Only the most desperate, or most unfortunate, gave birth alone in a field or a hedge, or dragged themselves to a church porch, and even they would, most likely, soon find assistance from other women. ${ }^{136}$

Gough's third case is the above-mentioned 1694 case involving Andrew Weston. The next case, the fourth, is the only one mentioned by Gough to have concerned Myddle and a parish outside of Shropshire. Of this dispute, Gough says that an unnamed "yonger son of

\footnotetext{
${ }^{134}$ This has been long recognized. Geremek, for instance, emphasizes itinerancy as the main impediment to being able to comprehensively reconstruct the world of marginal groups and surmises that "[m]obility aroused unease," and thus, the poor, who tended to also be highly mobile, "were in some sense 'strangers,"' and consequently distrusted. Geremek, 301.

${ }^{135}$ Patricia Crawford and Laura Gowing, eds. Women's Worlds in Seventeenth-Century England: A Sourcebook (New York: Routledge, 2000), 146; Ruth Mazo Karras, Unmarriages: Women, Men, and Sexual Unions in the Middle Ages (Philadelphia: University of Pennsylvania Press, 2012), 70.

${ }^{136}$ David Cressy, Birth, Marriage, and Death: Ritual, Religion, and the Life-Cycle in Tudor and Stuart England (New York: Oxford University Press, 1997), 76-77.
} 
Charles Reve of Myddle Wood," had returned to Myddle to live with his brother after having lived in Gloucestershire for over a year. ${ }^{137}$ Gough does not provide either Charles Reve's son's name or the name of the Gloucestershire parish in which he lived, but the July 1698 quarter sessions record that the dispute was between Myddle and the Gloucestershire parish of Beercroft over the settlement of one Francis Reve. ${ }^{138}$ In an attempt to communicate his general disapproval of Reve's character, Gough mentions that while in Gloucestershire, not only did Reve acquire settlement in Beercroft, but had also acquired syphilis during the course of his residence there. ${ }^{139}$

This case is similar to that involving the maintenance of Andrew Weston by his son-inlaw, in that Reve's brother was not able to support him due to his own indigence, and so Myddle became responsible for maintaining him, reportedly paying him $2 \mathrm{~s} 8 \mathrm{~d}$ per week. ${ }^{140}$ Myddle's officials, feeling that Reve's actual place of settlement was in Beercroft, had him removed there, and the matter went to the Shropshire quarter sessions when officials in Beercroft decided to appeal. As with Humphrey Beddow, residence and employment were central issues, with the specific matter of Reve's settlement hinging on the length of his hiring contract in Beercroft. Gough reports that Beercroft's officials argued that Reve was only employed "by the week for a quarter of a yeare," and after this time was employed for the remaining nine months. Beercroft's representatives argued that since Reve's employment term was not for an uninterrupted year, which according to the laws regarding settlement would have rendered him settled there, he was

\footnotetext{
${ }^{137}$ Gough, 255.

${ }^{138}$ Orders of the Shropshire Quarter Sessions, 174.

${ }^{139}$ Gough euphemistically writes that Reve "had gott[en] the French pox." Gough, 255.

${ }^{140}$ Gough, 255.
} 
not eligible for relief in that parish. Myddle disputed this and conversely argued that Reve's employment in Beercroft had been for the entire one-year period.

At the sessions, Myddle's officials were able to produce an eyewitness to Reve's hiring who testified that while Reve was indeed initially hired by the week for three months, after that time, his contract comprised a full-year term of employment. Apparently, this occurred at around the time that Reve returned to Myddle, which seems to have been a matter of some confusion in regards to his proper place of settlement. In any case, Beecroft requested that the matter be continued at the next sessions and promised to pay 10 s in costs, something which the quarter sessions records confirm. ${ }^{141}$ It turns out that the matter was never resolved, however. Gough reports that the parish "heard noe more" from Beercroft's officials, perhaps because, as it was rumored, Reve himself had died in the interim. ${ }^{142}$ The other possibility not mentioned by Gough is that he had simply moved on and traveled elsewhere in search of employment.

With cases five and six, which both involved the parish of Condover, Gough's narrative returns to the infamous Beddow family. The first case, which Gough mentions was heard at the same July 1698 sessions as the Reve case above, involved Elizabeth Davies and William Gittins, the daughter and son-in-law of Humphrey Beddow. ${ }^{143}$ Beddow's daughter, Gough disparages, "was an idle, wanton wench, always following after soldiers" who had become pregnant by Gittins, a soldier to whom she had been married. ${ }^{144}$ Davies came back to her mother's residence

\footnotetext{
${ }^{141}$ Quarter sessions records indicate that in the case of Beercroft, Gloucestershire v. Myddle, "as to Fras. Reeves, saved, with costs of 10s. against Beercroft ..." Orders of the Shropshire Quarter Sessions, 174.

${ }^{142}$ Gough, 256.

${ }^{143}$ Gough consistently refers to Beddow's daughter using her father's surname, but quarter sessions records refers to her by her mother's surname of "Davies." Why this is so is not entirely clear, but perhaps denotes that Elizabeth herself was illegitimate. Gough, 256; Orders of the Shropshire Quarter Sessions, 181.

${ }^{144}$ Gough, 256.
} 
at "Haremeare Heath," ${ }^{145}$ where Gittins often came to visit her. Knowing this, parish officials lay in wait and brought Gittins before Mr. Hunt, presumably a justice of the peace for Shropshire. ${ }^{146}$ During his settlement examination, which is unfortunately non-extant, Gittins maintained that he was born in "Masbrooke [Maesbrook?],"147 but that his last parish of settlement was Condover, where he had served as a hired servant before becoming a soldier and marrying Davies. The couple was reportedly married in the nearby parish of Ruyton. Why their marriage took place there, as opposed to either Condover or Maesbrook, is unmentioned. After this examination, it was ordered that Gittins be sent back to Condover, along with his wife and child. In the meantime, however, Gittins absconded.

Illustrating the ways in which Gough's account obscures the realities of life for many of the individuals about whom he writes, from the point of view of Gittins, fleeing was perhaps the only option in trying to manage his own fate. In fact, disbanded soldiers could be especially vulnerable poverty. In his study of how individuals "became" poor in Turin during the eighteenth century, Luciano Allegra points out that historians have tended to neglect study of their lives "between military campaigns or after desertion - how they made ends meet for themselves or their families." ${ }^{148}$ Just as others in economically-dependent and seasonal occupations, soldiers, many of whom "were already poor by birth," frequently "wandered the streets of the cities." 149

\footnotetext{
${ }^{145}$ Again, this location was probably in the vicinity of present-day Harmer Hill.

${ }^{146}$ This likely refers to Thomas Hunt, a justice of the peace whose signature appears on several settlement certificates throughout the first quarter of the eighteenth century. Myddle Parish (Shropshire), Settlement Certificates, 1702-1757, P201/L/4 (Shropshire Archives, Shrewsbury).

${ }^{147}$ This probably denotes the settlement of Maesbrook within the Shropshire parish of Kinnerley, located in the northwest of the county and bordering Wales.

${ }^{148}$ Luciano Allegra, "Becoming Poor in Eighteenth-Century Turin," Journal of Interdisciplinary History, 46, No. 2 (Autumn 2015): 170.

${ }^{149}$ Allegra, 170.
} 
Reflecting the primary financial concern at the core of these types of disputes, Condover then decided to appeal. Even though Gittins himself had run away, Condover was still responsible for supporting his wife and child. As in the case involving Reve, the matter hinged on Gittins's hiring contract. Condover was able to produce a witness who testified that she had overheard Gittins's employer say on his hiring that he would employ him temporarily, or "on tryall," and never knew him to be hired for a full year. ${ }^{150}$ The woman, who was a maidservant and had served in the same house as Gittins, nonetheless said that Gittins had served one year before becoming a soldier. Gough reports that on the basis of Gittins's own testimony combined with that of the maidservant, officials decided to uphold his removal, along with that of his wife and child, concluding that "hee had a good settlement in Condover Parish." ${ }^{151}$ Quarter sessions records corroborate that the removal order to Condover was confirmed. ${ }^{152}$

Still, this was not the end of the matter, for Gough states that around two years later parish officers from Condover removed Davies and her child to Myddle. Condover's officials now referred to her by the surname Beddow and feigned that her marriage to Gittins had never taken place. ${ }^{153}$ Myddle's officials appealed the removal order at the July 1699 sessions. Because upon marriage a woman obtained her husband's parish of settlement, Myddle used Davies's marriage as the basis for her settlement in Condover. To this end, Myddle was able to prove that the nuptials had taken place through the testimony of the parson from Ruyton who had

\footnotetext{
${ }^{150}$ Gough, 256.

${ }^{151}$ Gough, 257.

${ }^{152}$ Orders of the Shropshire Quarter Sessions, 174.

${ }^{153}$ Although Gough says that this matter took place "[a]bout two yeares after this contest [Gittins's case]," both Davies's removal order and quarter sessions records reveal that the case was heard just one year later, at the July 1699 sessions. Gough, 257; Orders of the Shropshire Quarter Sessions, 181; Removal Orders, 1683-1792, P201/L/5 (Shropshire Archives, Shrewsbury).
} 
performed the marriage, along with "severall persons" who had attended the wedding. ${ }^{154}$ Myddle was also able to produce the marriage certificate. In the end, the order was reversed. Gough discloses that he and the other parish officials gave her a shilling to go back to Condover with her child, which "spared us the charge of bringing her tither." ${ }^{155}$

Underscoring the easy transitions between the jurisdictional and moral, it is at this point in Gough's narrative that he pauses to further criticize the Beddow family, writing: "Thus you have seene (in three contests) what great trouble and costs wee have been att about this outcomne drunken Cobler and his famyly."156 He also laments that the parish had twice set Beddow's unnamed son as an apprentice, only to have him run away and end up in prison. It seems young Beddow, like his brother-in-law William Gittins, found refuge, or at least some amount of freedom, in itinerancy. One of these apprenticeships is confirmed in the 1684 apprenticeship indenture of Daniel Beddow to Richard Lockley of the parish of Clive, and is signed by Gough himself. Because, as the justices of the peace record, "Humphry Beddow of the parish of Myddle in the County of Salop hath a greate charge of small children which he is not able to mainteine without Releife and Assistance from the said parish," the minister and churchwardens for Myddle arranged Daniel Beddow to be set as an apprentice to Lockley as a carpenter (Beddow's apprenticeship is also discussed in chapter six). ${ }^{157}$

The various Beddow cases show how gender was a meaningful dynamic in the moral judging of the poor. As outlined, Gough places most of the blame for the family's laziness and immorality on Beddow's wife, Mary Davies, for improperly raising her children before going on

\footnotetext{
${ }^{154}$ Gough, 257.

${ }^{155}$ Gough, 257.

${ }^{156}$ Gough, 257.

${ }^{157}$ Myddle Parish (Shropshire), Apprenticeship Indentures, 1672-1891, P201/L/8 (Shropshire Archives,
} Shrewsbury). 
to complain about the level of support Myddle was required to provide for her family. For instance, Mary's mother, Sina Davies, who had since died, had been on parish relief for several years. In an iteration of the familiar meme of the sturdy beggar, a specter that had been a cultural bogeyman since the late Middle Ages, Gough accuses Davies's mother of habitually pretending lameness while begging for handouts. "The Beggars Song," a late seventeenthcentury ballad, reiterates this idea, describing the roving life of a group of vagrants: "For we are so Lazy we cannot Work, / there is other ways to gain, / Sometimes we are Blind, or else we are Deaf, / or else we feign to be Lame." ${ }^{158}$

The parish of Myddle also maintained Mary's brother, Andrew Davies. Gough calculates that this Andrew, who had been blind from infancy, had "received from the Parish $£ 3$ per annum for forty yeares and more, which comes to above $£ 120 . " 159$ In total, Gough reckons that if all of the costs for maintaining the family were added up, the amount would add up to around $£ 150$. Gough then imagines: "The Stygian fiend can scarce such mischiefe doe man, as / This drunken cobler and dissembling woman has." According to Hey, this is a play on a verse attributed to Pope Pius II, whom Gough refers to in the text by his Christian name, Eneas Sylvius. Gough includes the original thus: "Non audet Stygius Pluto tentare, quod audet / Effrcenis Monachis, plenaque fraudis anus [Not Stygian Pluto ever durst pursue, / What a rogue Monke, and treacherouse Hag dare doe.]." ${ }^{160}$ Like Andrew Weston, the blind Davies receives no apparent sympathy.

\footnotetext{
${ }^{158}$ Many features of this carefree, rambling life bear a passing resemblance to the Land of Cockaigne, a mythical medieval peasant paradise and land of plenty. Note that this ballad is also cited and discussed by Waddell. "The Beggars Song, Both in City and Country ..." (1686-1688), Magdalene College, Pepys Library, Pepys Ballads 4.250, English Broadside Ballad Archive (EBBA), University of California Santa Barbara, EBBA ID: 21910, accessed 11 December 2017, https://ebba.english.ucsb.edu/ballad/21910/xml; Waddell, 192.

${ }^{159}$ Gough, 258.

${ }^{160}$ Gough, 258, 332 n. 17.
} 
Gough's choice of adjectives both here and in other portions are significant, reflecting as they do gendered norms. This mirrors what Laura Gowing terms a comprehensive "language of gendered abuse," exhibited in London court records that details how women were much more likely to be personally insulted by claims made of their sexual misconduct - by being called a "whore" for example - than men. In contrast, men were almost as likely to be criticized for their spouse's sexual misdeeds or non-sexual transgressions as their own sexual disobedience. ${ }^{161}$ Gough calls the women in the Beddow family "wanton" and "dissembling," and Gowing additionally finds that "[m]any insults connected concerns about poverty, disorderliness, and dirt with the realm of the sexual, combining familiar themes with inventive elaboration along these lines: 'maggottie whore,' 'mangy carrion,' 'shitten whore, ' 'pockey lousey hedge whore,' 'tinckers truell,' 'twopenny whore;' 'scurvie fatt arst quean', 'gouty legged whore,' 'daggletaile queen.'"'162 Interestingly, it was women physically and symbolically outside the confines of the household, indeed as many itinerant poor women often were, who were dangerous, in terms of their potentially wanton and treacherous natures: "[i]n the ideal vision of the ordered household, the honest wife is tied to the house and its concerns.... [while] the unchaste woman, [stands] 'loosened' from the ties of the household body ..." ${ }^{163}$ Or, as Gough represents the ethical dichotomy: men of tainted morals are drunken, and often lazy, while morally tarnished women are dissembling and deceitful.

Gough does not confine this type of faultfinding to the Beddow and Davies families. Elsewhere in The History of Myddle, he bemoans the fact that he was currently paying a poor rate of 20s per year, while his father had only paid four pence in the 1630s, at which time there

\footnotetext{
${ }^{161}$ Laura Gowing, Domestic Dangers: Women, Words, and Sex in Early Modern London (New York: Oxford University Press, 1998), 59, 63.

${ }^{162}$ Gowing, 66-67.

${ }^{163}$ Gowing, 86 .
} 
was only one person on parish relief. ${ }^{164}$ In this type of grumbling, Gough seems to be voicing a common concern and a frequent criticism of the pre-1834 Old Poor Law — that it was an undue burden on taxpayers. ${ }^{165}$ Thus, Gough's narrative here once more betrays regard for the poor in a fiscal rather than a compassionate sense, yet at the same time is highly imbued with moral judgment. Though Gough's purpose in describing these settlement cases is arguably not moral, the text seems to communicate an overall dispassionate view of the poor and their plight. Ultimately, Gough's concerns were the concerns of England's rural propertied classes, and his emphasis on property and lineage means that the rootless and transient are generally viewed negatively. But, perhaps we should not judge Gough too harshly, for the post-1601 parish was undoubtedly financially overstretched and trying to deal with what had become a growing problem in the Tudor and Stuart periods, a phenomenon that has been termed "a new kind of poverty." ${ }^{166}$ Although by the beginning of the eighteenth century poor law administration cannot necessarily be called a "new" kind of role for the parish, it nevertheless was one with which it often struggled, as Gough's narrative and official records clearly demonstrate.

In addition, the two Gittins-Davies cases are illustrative of just how vagrancy was such a perceived threat to the social order. The poor were a menace not only because they were mobile, and accordingly ruptured the bonds of community. They were also a danger to more respectable society because they often "broke with the accepted norms of family life." ${ }^{167}$ In short, elites often characterized them as unreliable. In the view of individuals like Gough, they were difficult

\footnotetext{
${ }^{164}$ Gough, 146.

${ }^{165}$ Other criticisms of the Old Poor Law were that it was destructive to the yeomanry, lowered wages, encouraged population growth, and encouraged the very poverty it was meant to relieve. Mark Blaug, "The Myth of the Old Poor Law and the Making of the New." The Journal of Economic History 23, no. 2 (June 1963): 151.

${ }^{166}$ Beier, xxi, 3.

${ }^{167}$ Beier, 51 .
} 
to pin down, or to control. In response to help from the parish, unappreciative, they would abscond.

The breakdown of the nuclear family was frequently an instigator of poverty. ${ }^{168}$ Poor families were often broken up, either by circumstance and the need to make do or by parish officials. The predominant story, as A. L. Beier writes, is one of "fragments, of individuals cut adrift from kin and masters," most of whom were single men. ${ }^{169}$ As a result, abandonment by the male partner was the standard model for family fragmentation. ${ }^{170}$ After all, Gittins deserts his wife and child after his apparent fear of being officially removed to Condover. The couple also seems to have spent most of their married life living apart. At least for the itinerant lower classes, this would have probably been more the rule than the exception.

But, family breakdown was a complicated issue. Viewed one way, the poor's claims to family rights were quite tenuous:

The policies of overseer and magistrate alike might tear apart the households of the poor only to reconstitute them forcibly on principles of labour discipline, and might even ... prevent them from being formed at all. Both marriage and the exercise of the responsibilities of parenthood were privileges to be granted to, rather than rights to be exercised by, the poor, whose claim to family life was rendered little more than conditional under the terms of the Elizabethan relief statutes. $^{171}$

In this sense, the fragility of family ties was a consequence of poverty, not only an effect of the condition itself but also a result of top-down efforts at control. Intriguing, however, is the suggestion that in some cases it could have represented the agency of the poor, rather than their oppression:

\footnotetext{
${ }^{168}$ Healey finds in the late seventeenth-century town of Bolton, Lancashire that nuclear family breakdown was a cause of poverty for "70.1 per cent of households and 46.7 per cent of individual paupers." Jonathan Healey, "Poverty in an Industrializing Town: Deserving Hardship in Bolton, 1674-99" Social History 35, no. 2 (2010): 135.

${ }^{169}$ Beier, 52.

${ }^{170}$ Beier, 52.

${ }^{171}$ Hindle, On the Parish, 57-58.
} 
In extremis poor households deliberately fragmented. The desertion of wives and children by hard-pressed husbands could even be said to be an extreme example of rational and calculating behaviour on the part of poor families which is revealed time and atime again. Single mothers, poor widows, and hard-pressed married couples were perfectly capable of sending their children to live with relatives, sometimes many miles away, as well as leaving them on the parish. Reduced levels of family sentiment was, in itself, a survival strategy. ${ }^{172}$

The remaining settlement case was between Myddle and the Shropshire parish of Wem over Nicholas Hampton. Hampton, who was born in Wem, was hired as a servant for a year in Myddle, and returned to Wem when his period of employment was finished. Then, Hampton, who lived with his poor mother, became lame. After Wem had maintained him for around eight or nine years, parish officials removed him to Myddle in $1700 .{ }^{173}$ Though the reasons for Hampton's removal are unknown, it is fair to at least presume that the costs of both his and his mother's maintenance were probably substantial. Wem's resources, like those of most parishes, were probably overextended. Perhaps Hampton's removal, as others in this chapter, came down mostly to cost.

In any case, a long string of cases followed, after Myddle's representatives decided to appeal the order at the Easter 1701 sessions. ${ }^{174}$ Myddle's counsel argued that although Hampton was employed for one year in Myddle, his settlement was mitigated by Wem's paying of his relief for such a lengthy period. Wem's counsel argued that no payments had ever been made for Hampton's relief, though his mother's maintenance was acknowledged, and asked that the matter

${ }^{172}$ Jeremy Boulton, "'It is Extreme Necessity That Makes Me Do This': Some Survival Strategies of Pauper Households in London's West End during the Early Eighteenth Century," International Review of Social History 45 (Supplement) (2000): 66.

\footnotetext{
${ }^{173}$ Removal Orders, 1683-1792, P201/L/5 (Shropshire Archives, Shrewsbury).

${ }^{174}$ Orders of the Shropshire Quarter Sessions, 192.
} 
be taken up at the next sessions, until which point Wem was ordered to pay 20s to Myddle in costs. $^{175}$

At the next sessions, which took place in July 1701, Gough himself and another parish officer argued for Myddle due to the absence and sickness of two members of Myddle's counsel. Moreover, several justices were absent as well, and the chief speaker was the Mr. Clive who had signed the original order for Hampton's removal from Myddle. All this, in Gough's words, led to Wem's overconfidence and "made the officers and other persons of Wem there present to bee more than ordinarily confident of good successe. ${ }^{176}$ Reportedly, Wem's certainty about the case being decided in their favor led to them sending one of their members home. For these reasons, Gough, bending the truth, claimed that one of Myddle's witnesses was absent, and asked for another continuance, which was granted. ${ }^{177}$ Accordingly, Myddle was this time ordered to pay $15 \mathrm{~s}$ in costs and was deemed the party responsible for "maintaining the pauper till further order." ${ }^{178}$ The tone in such official documents is less judgmental as in Gough, but arguably just as depersonalized and patronizing.

The matter was finally decided several months later at the October 1701 sessions. ${ }^{179}$ Myddle again argued that Hampton had "long since" obtained settlement in Wem, both through his receiving of support and his "weareing of the Parish Badge." ${ }^{180}$ Reflecting the wide variety of practices regarding the badging of the poor, before it had become mandatory in 1697 , Wem had apparently required them to be worn. Whether to shame or merely mark out the poor

${ }^{175}$ Orders of the Shropshire Quarter Sessions, 192.

${ }^{176}$ Gough, 259.

${ }^{177}$ Orders of the Shropshire Quarter Sessions, 193; Removal Orders, 1683-1792, P201/L/5 (Shropshire Archives, Shrewsbury).

${ }^{178}$ Orders of the Shropshire Quarter Sessions, 193.

${ }^{179}$ Orders of the Shropshire Quarter Sessions, 194.

${ }^{180}$ Gough, 260, 332 n. 19. 
deserving of relief within the parish, Wem's intentions in requiring paupers' badges go unexplained. Gough reports that "the parishioners of Wem Parish had caused every one of theire poore to weare a P. made of tin. And that they caused this Nicholas Hampton to weare one of them (which was then shewed in Court)." ${ }^{181}$ This case, as Hindle notes, is an example of how paupers' badges could at times function as "currency in the inter-parochial exchange of settlement rights." 182

On the matter of Hampton's support, Wem's representatives argued that the receiving of money through charity did not create a settlement, rather it was a parish's paying of money, that is, as an institution, that did so. Mr. Fones, the counsel for Wem, remarked:

That the money was given of Charity and hoped their Charity should not bring a burthen [burden] upon them; and the weareing of the Badge was onely to save the Officers harmelesse from the penalty in the Act.... Mr. Newton [one of the justices] said that what money was given by one, two, or a few persons might bee accompted charity; for it was what ought by law to bee done, and hee did not insist soe much on the weareing of the Badge as the payment of money out of the Poor's Leawan [the parish poor rates]. Mr. Weaver [one of the justices] said that this person was borne in Wem parish; hee came into Myddle parish and there lived one yeare and then returned unto Wem Parish and fell lame: if this person turne[d] vagrant hee must bee sent to Wem not Myddle. ${ }^{183}$

Thus, the justices found in favor of Myddle. Hampton's removal order to Myddle was reversed and his settlement in Wem confirmed. Justice Newton concluded that while money given by a private individual could be considered charity, the distribution of money collected from the parish poor rates could not be, as this was an obligation required by law. In the end, the quarter sessions officials did not accept the nature of Wem's defense that Hampton's relief amounted to charity and was thus a private act that failed to translate into settlement. An

\footnotetext{
${ }^{181}$ Gough, 260.

${ }^{182}$ Hindle, "Dependency," 31.

${ }^{183}$ Gough, 260.
} 
important factor in deciding the matter for Justice Weaver was that although Hampton had resided and worked in Myddle for one year, he had returned to his birth parish of Wem.

Although all of Gough's settlement cases illustrate this point to a degree, Nicholas Hampton's case is singular for the scale in which the competition inherent in such inter-parish disputes is evident. Gough imbues the legal maneuverings that comprised this case with the sort of drama that undoubtedly existed in reality. After all, antagonism between parishes was implicit in a system that centered on settlement. As mentioned, there were other manifestations of this brand of "localism," such as when unnamed informers within the parish reported strangers likely to become chargeable to parish officials. ${ }^{184}$

In the end, the concerns of individuals like Gough seem far removed from those of their medieval counterparts. As the above cases show, by the late seventeenth and early eighteenth centuries, due to the immense pressures the parish was under to oversee poor relief, the poor stranger was more likely to be removed than to be received. Even more telling is the fact that many of Gough's settlement cases involve people who had resided in Myddle for at least some length of time, or were connected to long-standing residents by associations like marriage. Arguably, many of them were not even strangers at all.

\section{Conclusions: Settlement in Myddle}

The above documents demonstrate how settlement in the late seventeenth- and early eighteenth-century English parish could be quite fluid. Even after settlement came to be more strictly defined, parish officials still had considerable leeway in determining settlement. From Gough's writings, it is clear that settlement, far from being a finite concept, was determined through a variety of means. In the case concerning the chapelry of Hadnall's status within the

\footnotetext{
${ }^{184}$ Snell for instance examines the issue of what he terms "local xenophobia," something which he argues hindered the formation of class-based identity. Snell, Parish and Belonging, 28-80.
} 
parish of Myddle, geographical division was one of the main components comprising local identity, and was arguably the fundamental element pertaining to settlement. ${ }^{185}$ Boundaries were of obvious importance to the poor, primarily because they were the basis of parish relief. ${ }^{186}$ Another factor that affected settlement was the fact that family obligation overlapped with community obligation to the poor, as in the cases involving Andrew Weston and Francis Reve. Gender and age too complicated an individual settlement. ${ }^{187}$ For example, for women and children, marriage and place of birth took on greater importance than did work. In other words, life events, combined with their spatiality in terms of the place where such events geographically took place, assumed more weight in the process of determining settlement for women and children.

In contrast, for able-bodied men, settlement seems to have primarily revolved around their labor, an activity whose utility and its value for society as a whole had been emphasized since the post-plague period. Work had long been hailed as both a necessary and respectable activity. It makes sense that widespread fears of sturdy beggars and idlers, or those who would squander the parish's resources, might have continued to gain steam after compulsory relief took hold in the late sixteenth century. Possibly for this reason, the process of determining settlement took in the financial situation of the parish, through concerns over an individual's likelihood to seek relief.

As the various cases show, however, moral assessments of the poor frequently worked in partnership with such fiscal concerns, with negative judgments of a particular pauper's character often acting as a partial justification for his or her removal. This is typified by Gough's

\footnotetext{
${ }^{185}$ Snell, Parish and Belonging, 32.

${ }^{186}$ Snell, Parish and Belonging, 35, 39.

${ }^{187} \mathrm{~A}$ work that examines this issue in medieval France is Sharon Farmer's Surviving Poverty in Medieval Paris: Gender, Ideology, and the Daily Lives of the Poor (Ithaca: Cornell University Press, 2002).
} 
comments about both Humphrey Beddow's and Francis Reve's inebriation and Elizabeth Davies's sexual immorality. But, it is the common experience of itinerancy that ties Gough's cases to one another. In the much larger picture, it is the driving force behind late medieval and early modern attempts to control and deal with poverty. Anxiety about itinerancy was thus manifested at both the governmental and parochial levels, and was therefore a matter of broad concern.

These records reveal the boundaries placed on settlement, along with the financial stresses that seventeenth-century poor law legislation put on the institution of the parish. Above all, Gough's narrative allows us to see the moral judgments inherent in poor law administration in terms of the separating out of the deserving and undeserving poor. This reflects the fundamental problem associated with poor relief and charity: that what is given is never enough, else things would be as in Sir Thomas More's Utopia, where all received "a fair share" and there were "never any poor men or beggars." ${ }^{188}$ Poverty, as it was when More was writing in the sixteenth century, continued to plague society in the seventeenth and eighteenth centuries. As the eighteenth-century legal historian Richard Burn put it: "the plaister is not so large as the sore."189 But, if reality - whether historical or modern - teaches anything, it is that poverty is no easy matter, and that the deserving and the undeserving poor are so often differentiated is perhaps more a reflection of the limitations of the giver than those of the receiver.

\footnotetext{
${ }^{188}$ Thomas More, Utopia, trans. Paul Turner (New York: Penguin Books, 2003), 110.

${ }^{189}$ Burn, 144.
} 


\section{CHAPTER 4: BEYOND THE HISTORY OF MYDDLE:} SETLEMENT IN THE EIGHTEENTH CENTURY

\section{Introduction}

Richard Gough's description of various settlement disputes in The History of Myddle demonstrates the complicated ways in which a variety of issues came together to establish one's parish of settlement. These included an individual's age, gender, family size, work history and physical ability to labor, and likelihood of falling on parish relief. In this way, financial matters and moral judgments were intertwined. Gough's narrative illustrates how for men employment history was important in determining settlement. On the other hand, for women and children life events such as marriages and births were more significant influences than their employment history. As such, their settlements were defined more so by their relationships to male heads of households, whether husbands or fathers. From the parish's standpoint, valuable parish resources were at stake, and because of their potential financial burden those likely to seek relief often saw their membership in the parish community probed and questioned.

In this way, belonging, as understood through the legal concept of settlement and the stipulations regarding mobility from parish to parish, was not a choice for those seeking relief and was instead something frequently decided by parish officials and local justices of the peace. Therefore, although the poor possessed a certain amount of agency and were more than just the instruments of elites, their autonomy was limited by the very nature of the settlement laws. The poor were a mixt and heterogeneous group. But, if mobility was their general condition, their common bond came from, as Tim Hitchock and Robert Shoemaker observe, "the need to negotiate from a position of relative weakness." ${ }^{1}$

\footnotetext{
${ }^{1}$ Tim Hitchcock and Robert Shoemaker, London Lives: Poverty, Crime and the Making of the Modern City, 1690-1800 (New York: Cambridge University Press, 2015), 4.
} 
There is considerable overlap between the views put forward by Gough and the major themes within the surviving documentation related to settlement in the parish of Myddle. The most obvious connection between the two sets of sources is that several of the parish papers directly relate to some of the cases mentioned by Gough. In fact, it is likely that Gough drew on these documents as sources when compiling his local history. Such documents include a 4 July 1694 order rescinding Andrew Weston's earlier removal order from Preston Gubbals to Myddle upon Myddle's appeal and the adjudging of Weston's son-in-law, Thomas Williams, as fit to maintain him for 2s per week payable to the parish of Myddle; a 16 May 1698 removal order for William Gittins and his wife, Elizabeth Davies, along with a July 1699 reversal for the earlier order removing Davies "and her bastard Child" from Condover to Myddle; and a group of documents dealing with Nicholas Hampton's settlement dispute dating to 1701 (see chapter three for discussion of each of these disputes). ${ }^{2}$

More importantly, the various settlement examinations, removal orders, and settlement certificates similarly illustrate how local officials derived settlement from a number of influences. However, these sets of documents reveal that hiring contracts, or the one-year service agreements struck between rural laborers and their employers, for both men and women stand out as key elements in determining settlement. Thus, a fundamental difference is that while Gough mainly discusses married women, or those for whom life events had a larger role in establishing settlement than employment, here the importance of work history for single women stands out as a key factor. Another important departure from The History of Myddle stems from the fact that one of the main values of Gough as a source - namely, his verbose manner and chatty moral judgments upon the characters of various people - are mainly absent in

\footnotetext{
${ }^{2}$ Myddle Parish (Shropshire), Removal Orders, 1683-1792, P201/L/5 (Shropshire Archives, Shrewsbury).
} 
contemporary records. Though biased in their connection with determining settlement, controlling the movements of the poor, and reducing the parish's financial risk, Myddle's parish documents arguably provide a more impartial picture of the poor than Gough, and although their stories are again filtered through elites, communicate more of the poor's voice. For example, while Gough largely writes about the poor, parish officials had at least, through their interviews, talked to them. Moreover, historian K. D. M. Snell shows how, when read against the grain, settlement examinations, despite their official origins, are fundamentally "short biographical accounts of agricultural, artisan and urban workers," evidence of the type that rarely makes it into the historical record. ${ }^{3}$ Therefore, despite the fact that the poor were not a part of the actual record-making process, their voices dampened via the testimony given and recorded, settlement examinations nonetheless comprise valuable source material for uncovering the experiences of the poor. In short, they represent about as close as historians can get to reconstructing a reasonable facsimile of what their lives were like.

With these views in mind, within the collection of settlement examinations and removal orders from Myddle's parish chest are catalogued the unstable nature of the life of agricultural laborers, from their first positions of employment. They tell the stories of frequent moves from parish to parish to find employment due to the standard one-year hiring contracts of the period, laboring for multiple masters over the course of one's working life, illness, absence from home, and sources of conflict with employers. Settlement certificates and parish burial records speak to the existence of transient populations who resided in and passed through Myddle. These individuals would have been thought of as "strangers," and thus are the types of people not considered part of the parish community. Yet, these types of individuals did make claims on that

\footnotetext{
${ }^{3}$ K. D. M. Snell, "Settlement, Poor Law and the Rural Historian: New Approaches and Opportunities," Rural History 3, no. 2 (1992): 150.
} 
community at certain points in their lives, and their experiences, as reflected in the above sources, reveal another facet of community - that it was not static.

These records also express the ways in which poverty was a highly variable experience. For example, women and men with families not only experienced the above difficulties but also frequently came under the suspicion of local authorities because of their possibility of falling on parish support and sapping the financial reserves of the parish. These burdened men and women as a whole were more likely to be ordered to be removed by parish officials when compared with single men. Lastly, for women in particular, the loss of a spouse - either through death or abandonment - could be catastrophic, both in terms of economic hardship and one's treatment under the poor laws.

\section{Investigating Settlement: The Process}

As Gough's writings show, the system for determining settlement was one characterized by flexibility. Moreover, since it ultimately affected parish relief spending, and in turn local rate-payers, as Snell explains, "vestries and overseers often did all they could to restrict new people coming to belong." 4 At a functional level though, settlement laws did not necessarily prohibit mobility; instead, they were designed to prevent unsettled individuals from claiming relief. $^{5}$ Thus:

In these respects, 'belonging' via settlement was not a condition legally imposed from on high to a national uniform standard, prescribing a set of general strict criteria. The legislation and judicial interpretations of the 'heads' of settlement were flexible, hugely elaborated in legal manuals, and adapted to local conditions. 'Belonging' in this system meant to belong to a very local unit - the parish or

\footnotetext{
${ }^{4}$ K. D. M. Snell, Parish and Belonging: Community, Identity and Welfare in England and Wales, $1700-$ 1950 (New York: Cambridge University Press, 2006), 157.

${ }^{5}$ Paul Slack, The English Poor Law, 1531-1782 (New York: Cambridge University Press, 1990), 30.
} 
township - and for a century or more after 1662 it usually meant to belong via local usage, conditions and criteria. ${ }^{6}$

As an issue settlement touched the whole parish, and was manged by parochial overseers of the poor, but in settlement disputes it criscrossed local and regional spheres of influence, with the ultimate decision-making resting with justices of the peace. Settlement examinations were usually conducted at petty sessions in the presence of two justices of the peace. ${ }^{7}$ A usual settlement examination included an individual's name; place of birth; employment history, especially regarding apprenticeship or other contracted labor; marriage status; whether the examinee was able to rent a property worth at least $£ 10$ per annum; the parish or locality of any acquired settlement; and any other factors bearing upon one's settlement. ${ }^{8}$ The mid-eighteenthcentury examination of John Pickin is typical:

The Examin[atio]n of Jno Pickin John Pickin of Newton on ye Hill a Labourer in ye parish of Middle \& County of Salop upon his Oath saith that about eight years since att Last Christmas he was Hired a servant for one year by William Allen of Hunkington in ye parish of Upton Magna in ye said County of Salop and in pursuance of such hireing he Lived with him att Hunkington in ye said parish of Upton Magna for one whole year \& Rec[eive]d his whole years wages and Since he Left ye said service he hath not done any act whereby he hath Gained a Lawfull settlement in any other parish whatsoever

Taken and Sworn the 23d Day of May 1738
The mark of X

\footnotetext{
${ }^{6}$ Snell, Parish and Belonging, 134.

${ }^{7}$ Snell, Parish and Belonging, 136.

${ }^{8}$ W. E. Tate, The Parish Chest: A Study of the Records of Parochial Administration in England, 3rd ed. (New York: Cambridge University Press, 1969), 202-3.
} 


\section{Thos Hunt [signed] John pickin}

\section{A Coppy ${ }^{9}$}

As seen in the above example, settlement examinations catalog an individual's name, employment history, or at least those hiring periods lasting one full year or more, past masters, past and present parishes of residence, and parish of settlement, enabling the reconstruction of a person's employment history and movements. If married, the name of the person's spouse and names and ages of any children were also sometimes provided. However, information of this type was not always included within a settlement examination, and when not accompanied by a removal order or settlement certificate, which tend to record all members of an individual's family, it is admittedly not possible to determine a given individual's marital status or the existence of children with absolute surety. Settlement examinations thus tend to under-record married men with families, something that holds true for Myddle's collection of settlement documentation. For instance, John Owen's 1716 settlement examination makes no mention of his wife Mary and daughter Bridgett, who are both referenced in his settlement certificate from the chapelry of Hadnall, Myddle. Nor does William Hughes's settlement examination, taken on 8 November 1757, allude to his wife or children, although they are named in the family's removal order, dated the same day. ${ }^{10}$ On the other hand, exhibiting the gendered nature of the documents, marital status and the existence of any children both tended to be more regularly recorded for women who were examined.

Settlement examinations also occasionally mentioned the subject's age, occupation, parents' names and places of birth, their masters' trades, whether they worked for one year and Shrewsbury).

${ }^{9}$ Myddle Parish (Shropshire), Settlement Examinations, 1717-1808, P201/L/3 (Shropshire Archives,

${ }^{10}$ Settlement Examinations, 1717-1808, P201/L/3 (Shropshire Archives, Shrewsbury); Settlement Certificates, 1702-1757, P201/L/4 (Shropshire Archives, Shrewsbury); Removal Orders, 1683-1792, P201/L/5 (Shropshire Archives, Shrewsbury). 
received their full wages as per their hiring contract, and extenuating circumstances affecting their general situation, such as death of a spouse. All of the above types of information allow for the examination of the ways in which one's sex, age, marital status, and number of dependents affected their experiences under the poor laws.

An application for relief by a parish resident, arrival of a suspicious newcomer, or change in situation of a long-term resident making him or her likely to become dependent on parish support could all trigger a settlement examination. ${ }^{11}$ As such, the outcome of an examination was dependent on factors such as family size, illness, or family breakup through widowhood or desertion. ${ }^{12}$ Although single women were frequently liable to removal, Snell's research finds that those most likely to become chargeable to the parish were men aged about thirty-four with families, owing to the fact that any young children in the household were "economically unproductive" dependents. ${ }^{13}$ This matches up with the findings of Luciano Allegra's study of poverty in Turin during the eighteenth century, which indicates a spike in one's vulnerability to poverty between the ages of twenty-five to forty, corresponding with the period of family formation and raising small children, who were unable to become wage earners. ${ }^{14}$

The process of investigating one's settlement generally worked as follows. If an individual in question came under suspicion by parish officials but did not happen to be actually chargeable (that is, he or she was not actively on parish relief, as opposed to being considered likely to become dependent on the parish), he or she could decline to be examined. Except in

\footnotetext{
${ }^{11}$ K. D. M. Snell, Annals of the Labouring Poor: Social Change and Agrarian England, 1660-1900 (New York: Cambridge University Press, 1985), 17.

${ }^{12}$ Snell, Annals, 234, 359-60.

${ }^{13}$ Snell, Annals, 358.

${ }^{14}$ Allegra calls this a family's "consumer-to-worker ratio" and notes that its breakdown was often the key precipitator of poverty. Luciano Allegra, "Becoming Poor in Eighteenth-Century Turin," Journal of Interdisciplinary History, 46, No. 2 (Autumn 2015): 164, 181-83.
} 
cases where parish officials had reason to spend their time and parish resources on the matter, this often put further investigation to rest. If officials could take action within forty days, by which time the individual would gain settlement via his or her forty days' residency, they could also press for a settlement certificate from the legal parish of settlement. This was sometimes carried out simultaneously with a settlement examination. A simple residency period of forty days conferred settlement between the years 1662 and 1685. It was thus important for officials to move quickly, as not only oneself, but also one's spouse, children, and any servants or apprentices - essentially one's entire household - gained settlement in this fashion as well. ${ }^{15}$ Though records of expenditure are non-extant for Myddle, support of a pauper and his or her entire family could act as a sizable drain to parish funds. ${ }^{16}$ The various routes to settlement also demonstrate the manner in which women, children, and other dependents had a "'derivative'" settlement. In other words, their status was not self-substantiated, but was instead defined by their relation to another person, ordinarily the male head of household. ${ }^{17}$

Hiring for one year was a more direct method of gaining settlement. Indeed, for unmarried individuals whose families could not afford to pay an apprenticeship premium or who did not have enough money to rent a property worth $£ 10$ per annum, this was the only effective route to settlement. Young laborers customarily left home at about age fourteen, gained employment through annual hiring fairs, and travelled from parish to parish, year after year, until marriage. After marriage, a man no longer boarded or lodged with his employer and graduated

\footnotetext{
${ }^{15}$ Snell, Annals, 135.

${ }^{16}$ Hindle records that costs might average from 2 s to over 8 s per head of population. Hindle, On the Parish?: The Micro-Politics of Poor Relief in Rural England, c.1550-1750 (New York: Oxford University Press, 2004), 287-88, 296.

${ }^{17}$ Slack, 30.
} 
from a servant to laborer, in many ways a more insecure status that entailed weekly or daily contracting in place of yearly employment and weekly instead of annual pay. ${ }^{18}$

When one failed to gain a settlement in his or her own right through the various above methods, paternal settlement was next referred to, and after that, one's birthplace. ${ }^{19}$ If one's parish of settlement was determined as elsewhere, a parish had several choices on how to proceed. Sometimes, the person elected to move voluntarily, either returning to the parish of settlement or to another parish altogether, or he or she could be removed by parish officials via a formal removal order. However, the records are not always clear on the outcome of such cases, as sometimes no removal order can be found, reflecting that either the individual was not formally ordered removed or the record was lost.

Another alternative was for the parish to press the parish of settlement for a settlement certificate, which allowed the individual to reside in the parish, with his or her parish of settlement agreeing to be accountable for any relief the person might seek. ${ }^{20}$ Certificates began to be issued after 1696-7 because of the limitations and confusion created by the settlement laws, including the strict mobility restrictions and the labyrinthine impediments to gaining settlement for the laboring poor that they had created. ${ }^{21}$ Though arguably less visibly patronizing than the practice of badging the poor, settlement certificates were in some ways water in the same stream. Both actions identified and distinguished the poor while being public and official acknowledgements of a person's right to relief. As well, the issuing of certificates, like badging, indicated not only membership within the parish community, but also dependency.

\footnotetext{
${ }^{18}$ Snell, Annals, 73.

${ }^{19}$ Snell, Annals, 77-78.

${ }^{20}$ Snell, Parish and Belonging, 137.

${ }^{21}$ This was also the same act that brought back the practice of badging the poor. Tate, 199.
} 
A settlement certificate also had the added effect of demarcating one as an outsider in his or her parish of residence. Ultimately, certificates allowed the poor to remain within the parish to which they had migrated, relocations that were undoubtedly motivated by a search for work. ${ }^{22}$ Nevertheless, certificates were fundamentally meant to prevent settlement, and holding one was not necessarily an advantage. Theoretically, one might not be allowed to stay in a parish without one. ${ }^{23}$ Although a settlement certificate did give an individual some immunity from removal for being considered "likely to become chargeable," it was nevertheless a preventative to settlement in the parish of residence, something that someone lacking a certificate did not experience. ${ }^{24}$

Beginning in 1795, an individual could not be removed from a parish until actually chargeable. Thus, certificates are only found occasionally after this date, the main stimulus behind their issuing becoming redundant. ${ }^{25}$ In fact, even before 1795 , most parish immigrants appear not to have held them, and women were especially under-represented. ${ }^{26}$ Home parishes were often reluctant to issue certificates because a settlement certificate linked, in a legal sense, an itinerant individual to the parish for that person's - and perhaps even their descendants' lifetime. For instance, a settlement certificate could serve as evidence of settlement in an interparish settlement dispute heard at quarter sessions, in other words, the very type of litigation Gough details in The History of Myddle. ${ }^{27}$

\footnotetext{
${ }^{22}$ Charles A. Bernau, "The Genealogy of the Submerged," in Some Special Studies in Genealogy (London: Dunn Collin \& Co., Printers, 1908), 77.

${ }^{23}$ As Bernau reports was the case for the Surrey parish of Walton-upon-Thames, whose overseers and churchwardens also prevented those likely to become chargeable from establishing themselves there. Bernau, 75.

${ }^{24}$ Snell, Parish and Belonging, 100-1.

${ }^{25}$ Snell, Parish and Belonging, 102.

${ }^{26}$ Snell, Parish and Belonging, 100.

${ }^{27}$ Snell, Parish and Belonging, 130.
} 
The verbiage contained within a settlement certificate was simple and the document fairly brief, at least when compared with a settlement examination, which usually contained more biographical details. The average settlement certificate included the individual's name, the names of any spouse or children, the name and location of the issuing parish, the name and location of the parish of residence, and a declaration certifying that the issuing parish would be responsible in the event the individual or his or her family members should become chargeable to the parish of residence. Such documents were usually signed by the parish churchwardens and overseers and were witnessed by two justices of the peace.

The low degree of record survival creates problems in assessing the degree to which parishes across England harbored resident, non-settled laborers in the early modern period. In addition, there was great variation in how frequently - or even whether - parishes requested or issued settlement certificates. ${ }^{28}$ Moreover, it is clear that a number of residents within a given parish were "certificate men." Indeed, as Snell notes, "the gendering was not inadvertent," as women did not often hold certificates in their own names. ${ }^{29}$ Wives and daughters might, however, be mentioned in the settlement certificate for the male head of household.

In their management of the parochial influx of labor, settlement certificates were linked to whether or not a parish was an open or closed one. A closed parish was one in which parish affairs, including immigration, were strictly controlled either by a single person or a group of elites. Open parishes operated with a more "diversified power structure" and a less tightly controlled influx of labor. ${ }^{30}$ While scholars have traditionally defined parishes as open or closed, most parishes in the eighteenth century, especially rural ones, likely functioned in the middle,

\footnotetext{
${ }^{28}$ Snell, Parish and Belonging, 99.

${ }^{29}$ Snell, Parish and Belonging, 98.

${ }^{30}$ Byung Khun Song, "Parish Typology and the Operation of the Poor Laws in Early Nineteenth-Century Oxfordshire," The Agricultural History Review, 50, no. 2 (2002): 203.
} 
between these two extremes, employing a "targeted" approach to remove those newcomers most likely suspected of becoming chargeable. ${ }^{31}$ These were the people who were most often pressed for certificates. ${ }^{32}$ It has recently been deemed more useful to discuss parishes in terms of their relative "'openness or closeness'" than in their strict conformity to one model over the other. ${ }^{33}$ This more flexible paradigm is one in which Myddle fits well, as it was certainly not "closed" to migrants, yet at the same time officials exercised at least some control over immigration to the parish.

\section{Settlement in Myddle during the Eighteenth Century}

When examined for the years 1717-1800 and 1683-1792, Myddle's settlement examinations and removal orders respectively show intensified stresses on belonging in the parish during the last half of the eighteenth century. David G. Hey documents a period of change for Myddle after the 1720s that saw increased social stratification, a trend with which this data appears to correspond. ${ }^{34}$ A period of increased settlement incidents, defined here as the recording of a settlement examination and/or removal order, appears to have begun in 1753 and lasted until 1792, with the parish's last recorded removal order (see Figure 4.1 below). ${ }^{35}$

\footnotetext{
${ }^{31}$ Snell, Parish and Belonging, 128.

${ }^{32}$ Snell, Parish and Belonging, 128-29.

${ }^{33}$ Song, 204-5.

${ }^{34}$ David G.Hey, An English Rural Community: Myddle under the Tudors and Stuarts (Leicester: Leicester

${ }^{35}$ Note that there is an eight-year gap in Myddle's settlement records from 1739-1747. Settlement Examinations, 1717-1808, P201/L/3 (Shropshire Archives, Shrewsbury); Removal Orders, 1683-1792, P201/L/5
} University Press, 1974), 5-6, 230-31. (Shropshire Archives, Shrewsbury). 
Figure 4.1

Settlement Incidents in Myddle, 1693-1792

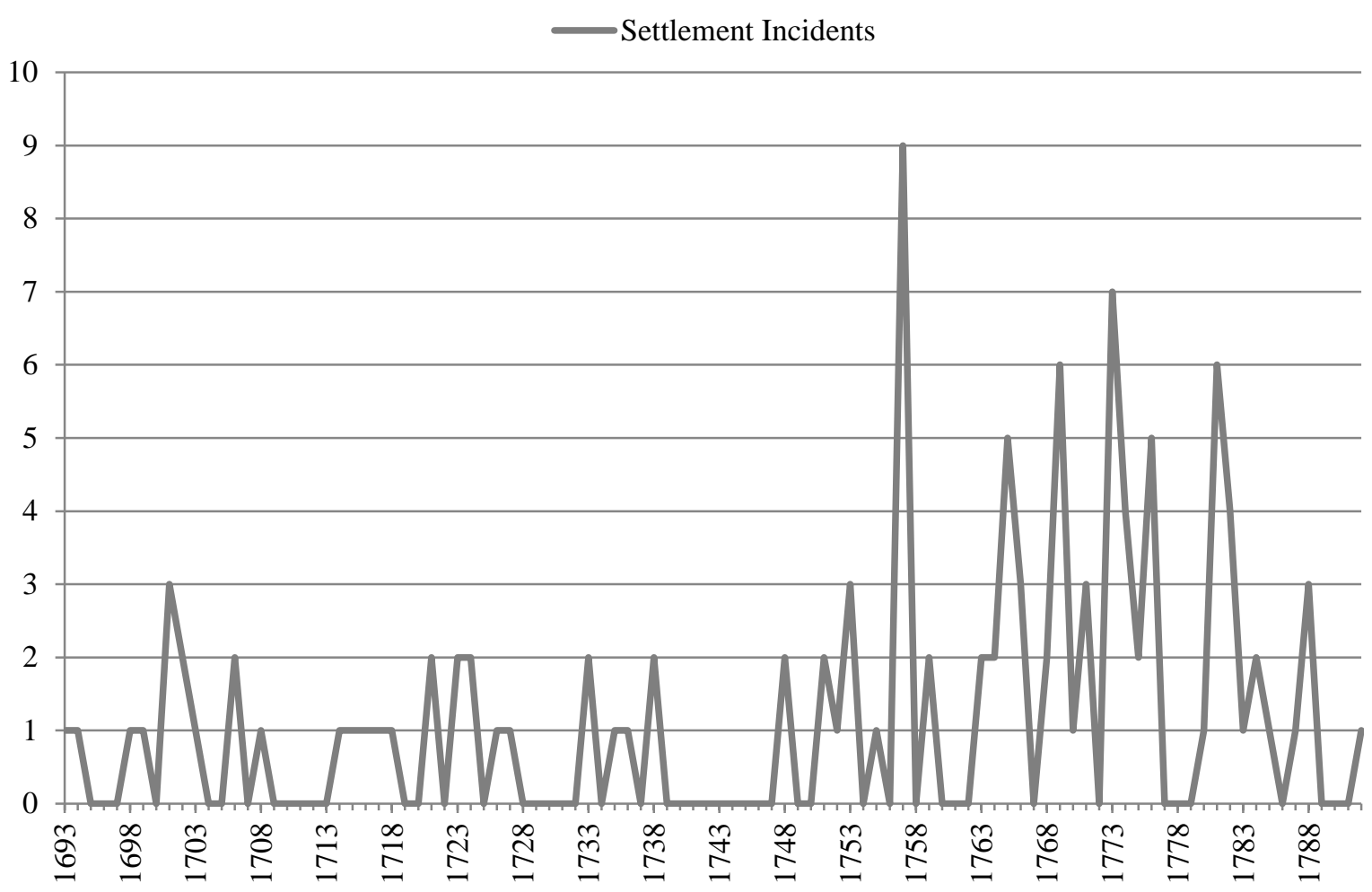

Myddle's settlement documentation shows that hiring contracts were by far the most common determiners of settlement both for men and women. Though a few people reported having resided in Herefordshire, Cheshire, Warwickshire, Staffordshire, Middlesex, Westminster, and various parishes in nearby Wales, the vast majority stated having lived in neighboring Shropshire parishes, most frequently Baschurch, Broughton, Ellesmere, Loppington, Preston Gubbals, Wem, and St. Mary's, located in the town of Shrewsbury. When it can be discerned by the type of testimony about family and work history, out of the 103 individuals interviewed and/or ordered removed, of whom 73 were male and 30 were female, hiring contracts appear to have been the basis for establishing settlement in 60 cases. Of these, 45 were men and 15 were women, meaning that for 62 per cent of males and 50 per cent of females, a hiring contract was the key factor in determining settlement. Other bases of settlement were 
one's parish of birth (five individuals), apprenticeship (five individuals), owning property and/or paying parish rates (three individuals), paternal settlement (two individuals), husband's settlement (two individuals), and holding a certificate from the parish of settlement (three individuals). In the remaining 23 examples, the derivation of settlement was either unspecified or unclear (or 22 per cent). ${ }^{36}$

In England and elsewhere in Europe, hiring contracts routinely involved one year's employment as a live-in farm servant, after which time the laborer was unrestricted from moving and contracting with another employer. ${ }^{37}$ In England, hiring contracts were intertwined with the poor laws. An unmarried person's hiring for a full year was one avenue to gaining settlement, as long as the period of employment was uninterrupted and the full wages were received. If the employment was disturbed or wages docked, which were not uncommon phenomena, settlement in that parish was then considered void. ${ }^{38}$ As Snell records:

[T] owards the later eighteenth century, the practice of hiring servants for less than a full year became increasingly common, notably in southern England, and this developed further in the early nineteenth century.... Settlement examinations document growing numbers of fifty-one-week hirings, sackings a few days short of the year, permissions to attend statute fairs a day or so before the year ended, seemingly generous permission to attend other local fairs, refusals to hire until a certain number of days after Michaelmas Day [29 September], permission to visit one's 'friends' (a word for relatives in this period) being used to discount settlement, unpaid absences for mothering Sunday, employer's consent to marry during the year, slight / deductions in yearly wages to 'prove' non-completion of the year, or swapping of masters during the year or for the last week of service. These and other methods were all deployed to hinder settlements. ${ }^{39}$

\footnotetext{
${ }^{36}$ Settlement Examinations, 1717-1808, P201/L/3 (Shropshire Archives, Shrewsbury); Removal Orders, 1683-1792, P201/L/5 (Shropshire Archives, Shrewsbury).

${ }^{37}$ John Mathieu, History of the Alps, 1500-1900: Environment, Development, and Society, trans. Matthew Vester (Morgantown, West Virginia: West Virginia University Press, 2009), 186.

${ }^{38}$ Snell, Parish and Belonging, 146.

${ }^{39}$ Snell, Parish and Belonging, 146-47.
} 
All of these tactics made gaining a settlement via hiring contract more difficult for the laboring poor, something that became even more so when yearly hiring was abolished as a "head," or creator, of settlement in $1834 .^{40}$

Settlement examinations were typically initiated by parish officials and legalistic in nature, consisting as they did of interviews meant to establish the proper parish of settlement for individuals who were deemed likely to seek poor relief and whose residency was in some way questionable. Even with their primarily "legal purpose," such documents are unique in that they catalogue the lives of agricultural laborers. ${ }^{41}$ In particular, settlement examinations illustrate the itinerancy of the rural laboring class and provide a broad depiction of the life of a typical laborer, an experience that was frequently marked by transience, "travelling about" in search of work. Some of the laboring poor were never in one place for more than one year at a time, the usual length of a hiring contract. Keeping the abiding image in mind "of shadowy figures moving at the edge of the community 'from Place to Place' and 'from door to door,"' an important question, but one to which a quantifiable answer is difficult to come by, is how many of these moves reflected choice and how many necessity. ${ }^{42}$ In any case, such an existence, illustrating well the need for parish officials to conduct settlement examinations, would have been an impediment to settlement.

Such portraits are scattered throughout Myddle's settlement examinations and removal orders. For example, the settlement examination of Robert Williams illustrates the precarious nature of hiring contracts. In April 1753, laborer Williams testified that he had been hired as a

\footnotetext{
${ }^{40}$ Snell, Parish and Belonging, 115-16, 120, 147.

${ }^{41}$ Tate similarly notes this as one of the chief values to settlement examinations as a historical source. Tate, 202; Snell, "Settlement, Poor Law and the Rural Historian," 150.

${ }^{42}$ Brodie Waddell, God, Duty and Community in English Economic Life, 1660-1720 (Rochester, New York: The Boydell Press, 2012), 192.
} 
servant in 1743 - about ten years previous - to one Thomas Penkiman. After his first year's service, "his s[ai]d Master died soon after but he continued with his Widow and served her the next five years following in the said parish of Wem ..." ${ }^{43}$ Even if he was lucky to remain with his master's widow, after that period Robert failed to be hired for a year or more elsewhere. The same held true for Edward Tillesley, who was examined the same day as Williams. Tillesley was hired as a servant ten years previous to Richard Griffith of Preston Gubbals, his last period of employment lasting a full year.

Although it is unknown whether either man was removed from Myddle, both Williams and Tillesley were married with children, which combined with their somewhat peripatetic work histories makes it easy to see why local officials might have been willing to question their rightful places of settlement. Men with young children were particularly vulnerable to questioning and removal, as in the case of Joseph Whotall, whose April 1702 removal order specifies that after his marriage in the parish of Myddle, he was "about to setle" there. ${ }^{44}$ Joseph and his family, which included three small children, the youngest of whom was under seven years old, were to be removed to Wem, his place of birth and where he had worked "some years" as a hired servant. ${ }^{45}$

Nonetheless, Whotall's work history seems to have been slightly more stable than was typical. On average, the individuals interviewed had lived in at least two parishes and, when their testimony about past work history specified, the average number of masters an individual had been employed by was three by the time they were questioned by officials. The work history of William Fardoe, who was interviewed in May 1757, is representative of Myddle's extant

\footnotetext{
${ }^{43}$ Settlement Examinations, 1717-1808, P201/L/3 (Shropshire Archives, Shrewsbury).

${ }^{44}$ Removal Orders, 1683-1792, P201/L/5 (Shropshire Archives, Shrewsbury).

${ }^{45}$ Removal Orders, 1683-1792, P201/L/5 (Shropshire Archives, Shrewsbury).
} 
records in terms of his number of employers and his movements to parishes within Shropshire: Fardoe was born in Ellesmere and about nine years previous, around 1748, was hired to Richard Fleming of Berrington. Next, he was hired for several months to Edward Millner of Cressage and then to Morris Hayward of Little Wenlock.

Even if the standard was service for one year, periods of employment could still be short, as both Fardoe's example and that of Samuel Jones show. Examined in October 1776, Samuel Jones was aged about twenty-five, was born at Eyton, Baschurch, and around age ten was hired by Mr. Weston of Eyton, whom he served for three years. After that he was hired "to Labor weekly" with a Mr. Husbands of Little Ness. ${ }^{46}$ Due to their purpose of trying to establish an individual's proper parish of settlement, the interviewers involved in settlement examinations such as these emphasized periods of employment lasting a year or longer, which conferred settlement. Since they would not have given an individual settlement, periods of unemployment and intermittent day labor are under-reported.

Despite the fact that they are not as explicit as in the two above examples, these gaps in regular employment can be glimpsed in the repeated breaks in several individuals' work histories. While it is difficult to ascertain employers' motives, the above cases demonstrate how the practice of hiring for less than a year could be utilized as a way to prevent settlement. ${ }^{47}$ Just as employers (who it must be remembered were frequently local ratepayers), might manipulate settlement to suit their ends, the poor had some control over their situation, and might plead their case using the language of deference or color their testimony to manipulate their settlement to the parish of their own choice, for example. However, as Steve Hindle cautions, care must be taken not to over exaggerate the poor's maneuverability in a system that was, after all, highly

\footnotetext{
${ }^{46}$ Settlement Examinations, 1717-1808, P201/L/3 (Shropshire Archives, Shrewsbury).

${ }^{47}$ Snell, Parish and Belonging, 146-47.
} 
weighted to their disadvantage. ${ }^{48}$ In many ways, the poor were at the mercy of those who recorded the particulars of their lives, and we, in turn, are dependent on the biased sources they have left to us.

The most extraordinary case of itinerancy was that of Thomas Williams, who was interviewed 20 January 1781. At the time, Williams was in his mid-twenties. According to him, about ten years earlier he was bound as an apprentice by the parish of Oswestry to Joseph Pugh of Ruyton for seven years, and next hired himself for one year to Francis Thomas of Hanmer, Flintshire, but only served nine months of his contract (no reason for this is stated). He then lived with a Mr. Kynaston of Lee, presumably of Ellesmere, for three months and following this, in 1776, he hired himself for one year to Thomas Walmsley of Newton-on-the-Hill in Myddle. He next worked for John Poole of Hadnall's Ease, also in Myddle, where he only served two months and was ill for about six weeks. Then, he worked for Mr. Elsmere of Upton Magna from May to Christmas 1778, Mr. Haughton of High Ercall for one month, and Mr. Barrett of Roddington for three months. Thomas then went to Birmingham for a month and afterwards returned to live with Mr. Phillips of Wroxeter for about two months, then with a Mr. Minton of Wheatley for about three months, and last a Mr. Kilvert of Preston Gubbals for about four months. Soon after this, he married. In all, Williams spent time in at least thirteen parishes from the time of his boyhood apprenticeship to the age of twenty-six. In only two instances did Williams's period of employment last for one year or more. Since a removal order is non-extant and his settlement examination does not indicate, the location officials determined his parish of settlement is unknown.

\footnotetext{
${ }^{48}$ Hindle devotes lengthy discussion to the ways in which poor relief was a process marked by negotiation by all of the key players: the parish vestry, local magistracy, and the poor themselves. Hindle, On the Parish, 360449.
} 
Since settlement examinations tended to examine work history, testimony concerning apprenticeship sometimes surfaces within them. This was because according to the settlement laws, apprenticeship in a parish created one's settlement there. Apprenticeship often marked the entry into the working world for many men, and some women. As in Williams's above case and for most young men, work history typically began with an apprenticeship, whether arranged privately by one's self or family or by parish officials utilizing parish funds to pay for the training of pauper children. On 26 March 1757, when his examination was conducted, John Evans was aged about twenty-nine. Evans was born in Myddle and was apprenticed to John Deakin in Wem, whom he served for five years, presumably as part of a privately-contracted apprenticeship, as no parish documentation survives from Myddle. Afterwards, Evans served Thomas Shaw of Marton, Myddle and subsequently Robert Wood of Burlington, Loppington, each for a one-year term. In his settlement examination, conducted in May of that same year, William Rogers indicated he was bound as an apprentice seven years previous to Chapman Williams of Cockshutt, Ellesmere but lived most of that time with his mother in Myddle. This appears to have been a private apprenticeship. Likewise, Jonathan Smith, examined in May 1773, had two months previous bound himself to Samuel Reynold, butcher, of Ruyton but never lived with his master. Taken as evidence for the decline of apprenticeship in the eighteenth century, these two examples reflect the practice of the "'clubbing out"' of apprentices. This became particularly common in the later part of the century with the deterioration of traditional forms of contractual employment and general decline in the position of the laboring classes throughout the century. ${ }^{49}$

\footnotetext{
${ }^{49}$ These phenomena are well-documented by Snell. On this point, a major feature of his argument, Snell writes: "Alongside the failure to serve the full seven years stipulated, the other most significant change was the growth in the later eighteenth century of 'clubbing out' apprenticeships. This would often involve the apprentice living with his family, or boarding, and moving to work or training with the master during the day, much as a
} 
Finally, John Pemberton's December 1766 removal order states that Pemberton, aged about thirty-four, had served an apprenticeship in Myddle and been "apprehended as Rogue and Vagabond within the Borough aforesaid [Saint Alban's, Hertfordshire] ..." ${ }^{50}$ This printed form, containing the harshest language of any of the settlement documents, originated from Saint Alban's and ordered Pemberton removed to Myddle, the place of his apprenticeship and presumably last regular employment. Unfortunately, nothing else about Pemberton is known. Still, though atypical, this example is instructive. It reveals the types of suppositions elites likely made about the poor. While actual attitudes might have been more moderate and less stark than the language appearing in this particular removal order, it arguably reflects assumptions that were probably less extreme but nonetheless very broad.

Many of those individuals who were examined appear to have been in their twenties or thirties, which reflects their having reached the age to work for a living and become heads of families, but older individuals were occasionally interviewed. For instance, on 20 January 1781, John Peg stated that he was aged about sixty-six and believed that his father's settlement had been in Clive, Saint Mary's. When he was aged fourteen or fifteen, John was hired to John Maddocks of Yorton in the parish of Broughton for two years. Since then, he had "lived in several services up and down in that neighbourhood till he was about 18 years of age. ${ }^{51}$ However, the last place he lived was with a Mr. Cuerton [Cureton?] of Balderton, Myddle for one year before he "left this country and went to Billson to work at Gun Barrels" and was married two years later. Whether Peg was removed is unknown. ${ }^{52}$

journeyman. The arrangement was similar in many respects to the living-out forms of farm service which developed in the same period [after c.1780] ..." Snell, Annals, 257.

\footnotetext{
${ }^{50}$ Removal Orders, 1683-1792, P201/L/5 (Shropshire Archives, Shrewsbury).

${ }^{51}$ Settlement Examinations, 1717-1808, P201/L/3 (Shropshire Archives, Shrewsbury).

${ }^{52}$ Settlement Examinations, 1717-1808, P201/L/3 (Shropshire Archives, Shrewsbury).
} 
Although men outnumber women in terms of settlement examinations, the settlement of several local single women were nonetheless probed. For example, in February 1752, "Ailce" [Alice] Lee stated in her settlement examination that she was born in Baschurch and "several times Hired for a y[ea]r to several persons but ... she never served a whole y[ea]r to any of them ..."53 Lee was considered likely to become chargeable to the parish of Myddle and was ordered removed to Baschurch, the parish of her birth. On 2 March 1757, Martha Davies stated that about sixteen years previous she was hired for one year to John Bate of Myddle and afterwards served various masters in the parish. About five years previous she was then hired to Alice Twiss of Hadnall for one year and afterward did nothing to create a settlement elsewhere. Also on 2 March 1757, thirty-three-year-old Martha Stephenton attested that about twelve years previous she was hired for one year to John Nicholls of Broughton. The next year she was hired to Thomas Cureton of Balderton in Myddle. Last, about six years previous she was hired to Mary Evans of Harlescott, Battlefield. Since then, and much like her male counterparts above, she had not earned a settlement elsewhere. In July 1775, Mary Bellingham, who was born in Myddle, reported that she lived there until she moved to Myddle Wood in c. 1786 for threequarters of a year. Afterward, she resided in Baschurch for two years and subsequently Fitz for one year, before she was hired within the parish of Atcham where she stayed for nearly four years. Susanna Hughs, also examined in July 1775 and born in Myddle, testified that she "hath lived since in several places." ${ }^{54}$ The last place she resided for any length of time was Albrighton, where she was hired by Thomas Ireland, Esqr. for one and a half years about ten or twelve years previous. Since that time she had lived with her parents, presumably at Myddle, but had not been in service.

\footnotetext{
${ }^{53}$ Settlement Examinations, 1717-1808, P201/L/3 (Shropshire Archives, Shrewsbury).

${ }^{54}$ Settlement Examinations, 1717-1808, P201/L/3 (Shropshire Archives, Shrewsbury).
} 
These various settlement documents point out that though poverty was a gendered experience, itinerancy was a universal condition that tied the various types of poor together. As Brodie Waddell points out, "The Beggars Song," a tongue-in-cheek account of the life of a group of vagrant panhandlers, reveals - inadvertently perhaps - how their experiences pivoted around wandering, which reveals how they " actually belonged to no place at all":

IN Summer time when Men make Hay we walk into the Fields, And spend our time in seeing what, dame Nature unto us yields:

If we do spy something we like, we pluck and do not spare, Till we are fully satisfy'd, and every one takes a share....

For we do pass from Town to Town, but for a time we stay, Least the Magistrates hear of us, and Whip us thence away. ${ }^{55}$

In addition to the most obvious sorts of issues they reveal, such as an individual's work history, family size, migrations, and resettlements, Myddle's settlement documentation catalogues other realities of life for the rural laboring class. These include attempts to visit family members while working away from their parishes of birth, illness, absconding and absenteeism, and various sources of disagreements between laborers and their masters.

The June 1751 examination and removal order for Mary Wynne, daughter of Thomas Wynne of Myddle, show that Mary was hired around three years previous as a servant to Thomas Barnet of Loppington and:

55"The Beggars Song, Both in City and Country ..." (1686-1688), Magdalene College, Pepys Library, Pepys Ballads 4.250, English Broadside Ballad Archive (EBBA), University of California Santa Barbara, EBBA ID: 21910, accessed 11 December 2017, https://ebba.english.ucsb.edu/ballad/21910/xml; Waddell, 192. 
[e]xcept about a ffortnight near the midle of ye s[ai]d y[ea]r when she by ye constent [consent] of her s[ai]d Master went away to see her brother who was then sick in the s[ai]d parish of Midle at Midle and then she returned to her said Master and served ye said y[ea]r out; but her said Master stopped Eighteen pence of her wages w[i]thout ye Consent of this Examinant... ${ }^{56}$

Joseph Shenton's master was kinder. In his settlement examination, which took place 1 May 1773, Shenton recorded that he was hired as a servant for one year to John Turner, farmer, of Myddle. Shenton served his full term of service excepting about eight days when he visited his father, who had had an accident, with his master's consent, and his wages were not docked. Shenton then served Turner another year, during which time he then married.

Laborers sometimes fell ill, occasions that interrupted their employment, reduced their wages, and therefore disturbed their settlement. In October 1765, Richard Phillips, aged about 30 and born in Harmer, Flintshire, had been hired for one year to his second employer, Joseph Minshaw of Ellesmere, whom he served excepting seven days during which he was ill. William Stanway came to Myddle after a year's work in the parish of Baschurch through his hiring as a servant for one year to John Bate of Myddle. During this time, William was ill for "many weeks," and his pay was reduced, but he testified in May 1773 "that he was altogether at his master's House during such illness." ${ }^{57}$ It does not appear that Stanway was removed from the parish. The same was not true of William Clift. In his April 1774 examination, Clift attested that while he was born in Myddle, his father was "under certificate from the parish of Ellesmere" and about five or six years previous his father rented a farm in Myddle of worth $£ 10$ per annum. ${ }^{58}$ About Michaelmas 1772 William was hired for one year to Thomas Broughall, farmer, of Balderton, Myddle, whom he served excepting one week during which he was ill and for

\footnotetext{
${ }^{56}$ Settlement Examinations, 1717-1808, P201/L/3 (Shropshire Archives, Shrewsbury).

${ }^{57}$ Settlement Examinations, 1717-1808, P201/L/3 (Shropshire Archives, Shrewsbury).

${ }^{58}$ Settlement Examinations, 1717-1808, P201/L/3 (Shropshire Archives, Shrewsbury).
} 
which his wages were docked. Clift and his wife Mary were removed to Hadnall, a chapelry within Myddle, with the reason unstated.

There are two examples of workers deserting their employers. The first of which is young Edward Williams, who was aged only about ten at the time of his ordered removal from Myddle to Ruyton in December 1736. William's age and testimony give the impression that he had absconded from his apprenticeship to tailor Andrew Morris. Also unclear is whether Williams had been set an apprentice privately, by his family, or by parish officials. In March 1757, current Myddle resident William Russell, blacksmith, was aged about thirty-five. Although he was born in "Lanterdine [Leintwardine]," Herefordshire, his father held a certificate from the parish of Shawbury. ${ }^{59}$ About seventeen years previous he was set a private apprentice by his father to John Groome of Hodnet. According to the record, Russell ran away from his master for two months and although he returned, he was absent at other points during his service. After his apprenticeship term ended, Russell was hired by his father in Shawbury for several years before coming to Myddle and renting a shop worth $£ 35$ s per annum. Though his examination records that he had made no other act to create a settlement in the parish, he was apparently allowed to remain, perhaps due to his employment as a blacksmith.

Although such episodes are infrequently catalogued within Myddle's records, an obvious point of contention between masters and servants was money. While the settlement cases from Myddle include only three instances of dispute between masters and servants, they reveal tensions over wages, absenteeism, and damage to tools and equipment. In December 1766, John Done, who was aged about twenty-four and born in Myddle, in either March 1757 or March

\footnotetext{
${ }^{59}$ Settlement Examinations, 1717-1808, P201/L/3 (Shropshire Archives, Shrewsbury).
} 
$1759^{60}$ was bound as an apprentice to shoemaker Rowland Stanway, the younger, of Myddle for three years. ${ }^{61}$ During this apprenticeship, John boarded and lodged with his father, Richard Done, and the agreement was eventually cancelled after two years, the reason unspecified. Prior to this, Done had served John Taylor of Saint Julian's, Shrewsbury, apothecary, as a shop boy but did not work a full year's service and received only goods in kind and no monetary wages, about which his mother reportedly complained, according to his testimony.

As shown in several of the above examples, the docking of wages was a common punishment for absenteeism as well as other offenses, such as damage to a master's property; it also interrupted one's settlement, which is the reason why accounts of such incidents were important to record in settlement documents. ${ }^{62}$ For example, Mary Bickley was examined and removed from Myddle in January 1720/1. While working as a servant for Thomas Astley of Wem, her wages were apparently docked six pence to pay for damages to a barrel hoop. ${ }^{63}$ The November 1757 settlement examination and removal order for William Hughes, who was born in Preston Gubbals reveals that when he was hired to Arthur Nunneley of Burlton, Loppington, after leaving the service of his first employer in Fennemore in the parish of Baschurch, he served Nunneley for eleven days less than one year, due to the 1752 change to the Gregorian calendar. Hughes's wages were docked 2s accordingly and he and Nunneley agreed to part ways. Hughes was ordered removed to Baschurch, the place of his first, uninterrupted employment.

\footnotetext{
${ }^{60}$ There are two settlement examinations for John Done, and the dates given in each for the beginning of his apprenticeship disagree.

${ }^{61}$ This same Rowland Stanway appears to have been himself apprenticed by the parish of Myddle to cordwainer to George Sherrat of Ellesmere in 1747. Myddle Parish (Shropshire), Apprenticeship Indentures, 1672 1891, P201/L/8 (Shropshire Archives, Shrewsbury).

${ }^{62}$ Snell, Parish and Belonging, 146.

${ }^{63}$ Records indicate that Bickley's removal order was contested by Wem and reversed by two local justices of the peace.
} 
Additional records reveal other incidents. According to his October 1769 examination, John Jones was aged about thirty-nine and the head of a family of five children. About twenty years before, he had worked for farmer William Eaton of Myddle. Jones served his year and left Eaton's service, but was afterward hired for another year and stayed for an additional year's work. Next, he was hired to farmer John Groom of Sleap, Wem, but left his service due to the fact that the two got into a quarrel during the harvest over an unspecified matter:

having some words the s[ai]d Groom paid Depon[en]t his Wages due to that Time and Depon[en]t went away from his service but upon the third Day after the s[ai]d John Froom sent a serv[an]t of his to Deponent desiring him to return which Deponent did and the said John Groom agreed with Deponent to serve the years service out $\&$ he would give him 5s[?] more Wages or otherwise a Waistcoat which Waistcoat Deponent accepted of and did serve the rem[ainde]r of the s[ai]d Term with the s[ai]d John Groom in the s[ai]d parish of Wem and rec[eiv]ed his full years Wages according to the first agreement and hath not since That time done any act to gain a settlement elsewhere.${ }^{64}$

Jones's testimony about his dispute with Groom and that of apothecary's apprentice John Done are examples of how poor laborers were sometimes paid in kind. According to Craig Muldrew, for example, in a society that often could be cash poor, "'wages were often paid long in arrears, which meant that even if the poor could find work they might have to rely on payment in kind . . ." 65 In addition, all of the above cases show how settlement examinations, meant to settle the issue of one's parish of settlement, can be instructive about the kinds of disputes that occurred between laborers and their employers.

Many of the above circumstances touched both men and women workers in similar ways. However, what Myddle's settlement documents furthermore reveal are the overall gendered nature of poor law administration as well as the basic differences between the male and female

\footnotetext{
${ }^{64}$ Settlement Examinations, 1717-1808, P201/L/3 (Shropshire Archives, Shrewsbury).

${ }^{65}$ Craig Muldrew, "'Hard Food for Midas': Cash and Its Social Value in Early Modern England," Past \& Present, no. 170 (February 2001): 105.
} 
experiences of young adulthood, labor, family life, old age, and poverty. Moreover, although not always the case, the settlement of women also tended to be viewed more in terms of their relationships to others; in other words, a women's settlement was not as often self-substantiating as a man's often was. ${ }^{66}$ Women were also far more likely to be removed from the parish under the poor laws. Out of the thirty women who appear within Myddle's settlement examinations and removal orders, 25 were removed. Eighteen of these were married and/or had children, while seven were unmarried.

In contrast, out of 73 males, just 24 were removed. Significantly, seventeen of those were "burdened," that is, those with wives and/or children. Because the existence of a removal order is positive evidence for removal, but the absence of one is not necessarily evidence of nonremoval, it is not possible to ascertain with surety how many burdened males were not removed. In all, there were 44 parish settlement documents involving burdened males, including 27 whose examinations did not generate an extant, corresponding removal order. In comparison, single men who could support themselves through their labor were the group least in danger, with just seven ordered removed. Or, put another way, out of the 29 single males examined, there were no equivalent removal orders for 22 of them. The best that can be said is that the fates of these men are unknown, but it seems reasonable to conclude that at least some of them were allowed to remain in the parish. Still, the evidence suggests that being burdened was a deciding factor in removal. In conclusion, it appears that while those of either sex with dependents were susceptible to removal, women stood a higher risk overall. Men with dependents were also

\footnotetext{
${ }^{66}$ Isabel V. Hull, examining the language used to describe unwed mothers in suits of illegitimacy in the German states, notes this same general tendency to see women indirectly in the eyes of the law. Ultimately, a woman "did not have a right by virtue of herself or her own condition as a person/citizen or the results of her sexual relation to a man, but only by virtue of her obligation to her child. ... In short, it was her relation to others in the form of duty to others that provided her rights." Isabel V. Hull, Sexuality, State, and Civil Society in Germany, 1700-1815 (Ithaca, New York: Cornell University Press, 1996), 397-98.
} 
subject to suspicion in ways that single men were not. In the end, the potential drain on parish finances combined with the nuances of the gendered power structure that valued male labor (explored in chapter three), seem to have been the most important driving forces in the application of settlement laws in Myddle.

Male and female experiences of poverty were also differentiated by the impact of the loss of a spouse. This is not to imply that widowhood was a universalized female experience, however. Class too was important. For upper-class women, widowhood often brought the type of freedom not available to married women, but it was a double-edged sword and the benefits of this newfound autonomy were status-dependent. Lower down on the social scale, it is telling as to their dependency and vulnerability that widows were often lumped in with other types of the "structural" poor, such as orphans, the sick, and the elderly. ${ }^{67}$ Settlement documents from Myddle illustrate how the death of a partner frequently brought hardship for those of meaner circumstances. The following settlement examination from parish of Walton-upon-Thames, Surrey reveals the difficult circumstances of widow Sarah Orley in 1725:

(Copy) - The Examination of Sarah Orley, widow, taken upon oath before us two of His Majesty's Justices of the Peace quoram [sic] unus Sr. James Edwards Barrt. \& Francis Henry Le, Esq., for the County of Surry the sixth day of Decr., 1725.

Sarah Orley deposeth upon Oath that she was travelling from Chipnam [Chippenham] in the County of Wiltshire with an intent to goe to Norwich in Norfolk ... Her Husband, Will: Orley a Carpenter by Trade who served His time as apprentice to the best of Her knowledge to Henry Spicer at Norwich in Norfolk by dying at Chipnam above mentioned did endeavour to goe to Norwich to find out His Relations to give Her releif, but being not able to gett there . . . was obliged to stay at Walton upon Thames above mentioned [sic] where she was delivered of a Female Child \& that her last Service was with Mr. Arthur Langford a Farmer at Exberry [Exbury] in Hampshire \& that she was married to William

${ }^{67}$ Laurence Fontaine, The Moral Economy: Poverty, Credit, and Trust in Early Modern Europe (New York: Cambridge University Press, 2014), 138. 
Orley when she was a servant to --- Pollett, Esq., at Lindall[?] in Hampshire about two years since \& farther sayeth not wittness my hand this Sixth day of December 1725.

Witness:

James Griffin, J. Edwards [signed] Her

Constabill [signed] F. H. Lee [signed] Sarah X Orley Mark. $^{68}$

The structure of this examination emphasizes Orley's potential burden to the parish. Whether pregnancy or lack of money prevented her from reaching Norwich, Orley's examination highlights the lack of resources the poor combatted on a daily basis, in addition to the attempts by local officials to manage their families through the hampering of the poor's mobility. The above illustration also shows how the death of a spouse could severely affect a family's security, and the privation associated with it often triggered a poorer family's move to another parish, whether that reflected an apparent voluntary search for work or involuntary removal by local officials. For example, the removal order for widow Anne Owen, whose residence in January 1713/4 was Myddle, reveals that she had migrated from Broughton, her late husband's parish of settlement for over forty years.

Tragedy also touched the family of Andrew Payne. Payne came to Myddle by a certificate from West Felton around 1722 with his wife Anne and daughter Elizabeth. After the family's move, Andrew passed away, leaving his family in "low Circumstances" and likely to become chargeable to the parish. ${ }^{69}$ Due to the certificate from West Felton, Anne and Elizabeth were to be removed there, in essence a forced migration to a place in which they had not resided for four years. There was also widow Sarrah Fardoe, who in June 1759 resided in Myddle, having previously lived in the parishes of Preston and Saint Mary's in the town of Shrewsbury.

\footnotetext{
${ }^{68}$ Bernau, 79-80.

${ }^{69}$ Removal Orders, 1683-1792, P201/L/5 (Shropshire Archives, Shrewsbury).
} 
Her reasons for moving to Myddle are unstated. The wording of her examination reveals Saint Mary's to have been her likely parish of settlement due to a hiring contract. As there is no removal order, her fate is ultimately unknown.

Yet, it was widows with young children who were especially vulnerable, as in Anne Payne's case. Mary Barnes, widow and mother of John, aged about seven, and one-year-old Edward, was removed from Wem to Myddle in September 1748. Mary Furmston, in December 1773 resided in Ellesmere with her three children: John aged about nine, William aged about five, and Phillip, aged about two. Although the basis for her settlement is unstated, Mary was deemed likely to become chargeable to the parish of Ellesmere and so was ordered removed to Myddle. Margaret Mountford lived in Myddle in 1792 and had previously lived in Baschurch, to which she was removed along with her four children: Mary aged about fourteen, Elizabeth aged about seven, Edward aged about four, and Deborah aged about eighteen months. The reasoning behind this decision is not recorded, but due to the size of her family and status as a widow, it is not difficult to see why officials considered her undesirable as a resident due to her likelihood of dependency on parish relief.

Women were far more likely to be negatively affected financially by their partners' deaths and thus were adjudged at risk of turning to parish support. While men could be also, the information recorded about them and their circumstances is generally sparser than that for women. Due to gendered ideas about labor, this indicates that widows were of much greater concern to the parish in terms of their possible financial burden. Three widowers are recorded. First is William Arnway, who lived in Myddle in September 1724 when his examination was undertaken. Arnway had previously resided in Child's Ercall, where he had labored as a servant, after which he had not been hired for a year or otherwise created a settlement elsewhere. On 26 
March 1757, Richard Davies was aged about fifty-four years and was born in Ellesmere. About twenty-eight years before his examination, he was hired by Robert Walford of Hadnall, Myddle and worked for him for three years. Afterwards, he was hired to William Poyner of Preston Gubbals but his hiring contract appears to not have covered a full year. Next, he moved to Smethcott, Hadnall, and rented a tenement worth $£ 25$ s and served as a petty constable there. However, his wife passed away and sometime after he worked as a day laborer for about two years to support himself and his two children. Then, Richard was hired by William Poyner of Lee Hall, Preston Gubbals for eleven years (it is not clear if this is the same William Poyner to whom he was previously hired). Richard remarried and had one child with his second wife. There is no extant removal order for Davies. Last is widower Joseph Harper, a laborer who in July 1782 resided in Myddle, having previously lived in the parish of Preston Gubbals. By this time, Joseph's wife Ann had died, leaving him to care for his small daughter Ann, aged about three. About nine years previous, or around 1773, and about five years before he married his late wife, Joseph had been hired as a servant for one year to John Garmeson, farmer, of Preston Gubbals; this was the contract that apparently served as the basis of his settlement. Whether Joseph was ultimately removed is unknown.

These examples notwithstanding, there is no better evidence of the singular vulnerability of women than that from Myddle's burial records, in which there is an unsurprising correlation between the terms "poor" and "widow": out of 75 female pauper and itinerant burials within the parish between 1600 and 1800, 31 of those women were described as both paupers and widows. This evidence does not mean that all widows were poor, or that widowhood necessarily began an inescapable descent into poverty. After all, this is a society in which second - or even thirdmarriages were common, and many widows and widowers would have married again. It does 
signify, however, the degree to which the death of a male head of household could drag a family down into poverty, especially one already experiencing difficulty in getting by. In other words, for those women who for whatever reason failed to find another partner, the lack of a husband made it all the more difficult for them to rise out of financial difficulty and get off parish support. That 41.3 per cent of the pauper and itinerant women buried in the parish were widows, further underscores just how common an experience impoverishment in widowhood was in this period. In comparison, no male paupers or vagrants were described as widowers. This type of recording emphasizes the distinction that women tended to be viewed through the prism of their husbands' and fathers' status, while men were assessed in terms of their own labor and ability to support themselves and their families.

Women who gave birth to illegitimate children, particularly one whose father was absent, also created special problems for the parish in terms of the poor laws. In practical terms, this meant that the family was without a breadwinner and so would be more likely to seek parish relief. The parish, in an effort to get financial reimbursement for the family's support, would often expend effort in trying to locate the father, and as the child grew older, might also be responsible for binding the pauper child out as an apprentice, in essence paying for his or her occupational training and moral reform. For example, the c. 1755 binding out of William Adams, who was born illegitimate in the parish of Saint Alkmund's, Shrewsbury, to George Cooke, a stonemason from Myddle, likely reflects such an apprenticeship. ${ }^{70}$ This reasoning follows both from Adams's illegitimate status and the fact that Myddle's apprenticeship records indicate that Cooke himself took on several of Myddle's pauper children. ${ }^{71}$

\footnotetext{
${ }^{70}$ The settlement examination of William Adams took place in May 1773.

${ }^{71}$ In fact, Cooke had himself been a pauper apprentice, and was set out to his father, local mason George Cooke, in 1721. William Cooke was apprenticed in 1754 to George Cooke, Jr. Moreover, John Davies and Joseph Cook were apprenticed to mason George Cooke/Cook in 1732 and 1770 respectively (although whether to George
} 
The possibility of such future accountabilities meant that the removal of women who were the mothers of bastard children to another parish was financially expedient. For example, recalling Gough's description of morally dubious families in Myddle, Elizabeth Nonneley, who was ordered removed from Myddle to Ellesmere in December 1706, was "a Bastard Child of one Ann Nonneley, (whose name att ye Birth of ye s[ai]d Child, was Sambrook)" and at the time was "under seven yeares of age .. . "72 Notably, it was Elizabeth's aunt, Elianor Scott, ${ }^{73}$ who was examined as to the child's proper place of settlement. According to Scott, Elizabeth was born in Ellesmere, but her mother, Scott's sister, eventually abandoned the child with her in Myddle. It is possible that officials were in effect returning Elizabeth to the care of her mother. However, her whereabouts were not stated and were perhaps unknown. Whichever the case, it appears that seven-year-old Elizabeth was compelled to leave Myddle for an uncertain future in Ellesmere.

Similarly, bastardy bonds and parish registers show that Jane Ellis gave birth to illegitimate children in 1754,1757 , and $1774 .{ }^{74}$ During this same period, Ellis, who was both examined and ordered removed from Myddle to Bangor, Wales in February 1776, attested that she was born in Myddle, but that she had "lived in several places." ${ }^{75}$ Her last employment was with James Smith of Bangor, Flintshire about six or seven years previous. After that, Ellis had

Cooke, Sr., George Cooke, Jr., or a later descendant of either individual is unspecified). For a discussion of the practice of apprenticing of pauper children to family members, see chapter six. Apprenticeship Indentures, 16721891, P201/L/8 (Shropshire Archives, Shrewsbury).

${ }^{72}$ Removal Orders, 1683-1792, P201/L/5 (Shropshire Archives, Shrewsbury).

${ }^{73}$ It is quite possible this was the very same Elinor Scott whose settlement case shows up in Shropshire quarter sessions records, which Gough fails to mention, and who was ordered removed from the parish of High Ercall to Myddle in 1692 (see chapter three). Kenyon, Robert Lloyd, ed., Orders of the Shropshire Quarter Sessions, vol. 1 (1638-1708) (Shrewsbury: Shropshire County Council, 1902), 140; Richard Gough, The History of Myddle, edited and with an introduction and notes by David G. Hey (New York: Dorset Press, 1986), 332 n. 7.

${ }^{74}$ Bastardy bonds, which are explored in chapter five, resulted from a parish's bid to hold the reported father of an illegitimate child responsible for his or her maintenance, resulting in the stipulation of payments to be made to the child's parish of settlement. Myddle Parish (Shropshire), Bastardy Bonds, 1710-1778, P201/L/6 (Shropshire Archives, Shrewsbury); W. P. W. Phillimore, ed., Registers of Myddle, Shropshire Parish Registers, Lichfield Diocese, vol. 19 ([Shropshire]: Shropshire Parish Register Society, 1931), 213, 218, 249.

\footnotetext{
${ }^{75}$ Settlement Examinations, 1717-1808, P201/L/3 (Shropshire Archives, Shrewsbury).
} 
worked for Bartholomew Mansel of Myddle, but left his service for an unspecified reason one month shy of a full year. Considering her somewhat large charge of illegitimate children, and seeming itinerant existence, it is not difficult to see why Ellis was again ordered removed to Bangor in February 1785 after her apparent return to the parish.

Mary Price's case is a further illustration of the precarious position of unwed mothers within the community. Despite the absence of a large portion of Price's October 1776 examination, which leaves out much of her work history, the surviving fragment reveals that she was aged about forty, was born in Burlton, Loppington, and "served in several places." ${ }^{76}$ As there is no mention of her being married, Price's five-year-old unnamed child was likely illegitimate. Her previous employment with one Abigail Chidloe within her parish of birth was the reason for her ordered removal to Loppington. In this case, work history was the primary reasoning behind removal, but it was probably true that parish support of an illegitimate child added to the haste: the removal order is dated the same day as her examination.

The most explicit case of illegitimacy spurring removal is that of Sarah Shaw. In March 1781, Shaw, currently of Myddle but previously of Ellesmere, was described as currently "big and Pregnant with Child, which Child when Born will be Born a Bastard and likely to be chargeable to the said Parish of Middle."77 The deep financial implications for the parish, which stood at risk of supporting such illegitimate pauper children from birth, created urgency for the parish to assign settlement elsewhere. The stories of women like Sarah Shaw reveal the sharpest questioning of one's settlement. Their elusive, fragmentary appearances in the historical record also expose the difficulty inherent in reconstructing the narratives of such women and their

\footnotetext{
${ }^{76}$ Settlement Examinations, 1717-1808, P201/L/3 (Shropshire Archives, Shrewsbury).

${ }^{77}$ Removal Orders, 1683-1792, P201/L/5 (Shropshire Archives, Shrewsbury).
} 
children. However, although it is a distorted lens through which to view their lives, their management by those in power and hardship is nonetheless apparent.

Other sources speak of such hardships, as well as the instability lurking beneath the concept of the parish community. For instance, Myddle's settlement certificates are further evidence of transience. In all, there were 46 certificate holders in Myddle from 1702 to 1757. When the dependents of settlement certificate holders are taken into account, the data show increased recording of certificates from the 1720 s through the 1740 s, with spikes at the beginning and end of the record-keeping period (see Figure 4.2 below). ${ }^{78}$ These numbers again seem to agree with Hey's analysis of eighteenth-century Myddle, which from the 1720s was characterized by more disparity in wealth. ${ }^{79}$ Following from Hey's conclusions, settlement certificate recording in the parish suggest an actual influx of outsiders, rather than just an overrecording. It is also likely that these people were in search of work in a Myddle that was now more divided between well-to-do farmers and financially insecure laborers and less egalitarian as it was before 1720 .

\footnotetext{
${ }^{78}$ Note that when certificates specify children to an individual or married couple but do not state a specific number, this has been estimated as referring to at least two children. Settlement Certificates, 1702-1757, P201/L/4 (Shropshire Archives, Shrewsbury).

${ }^{79}$ Hey, An English Rural Community, 5-6, 230-31.
} 


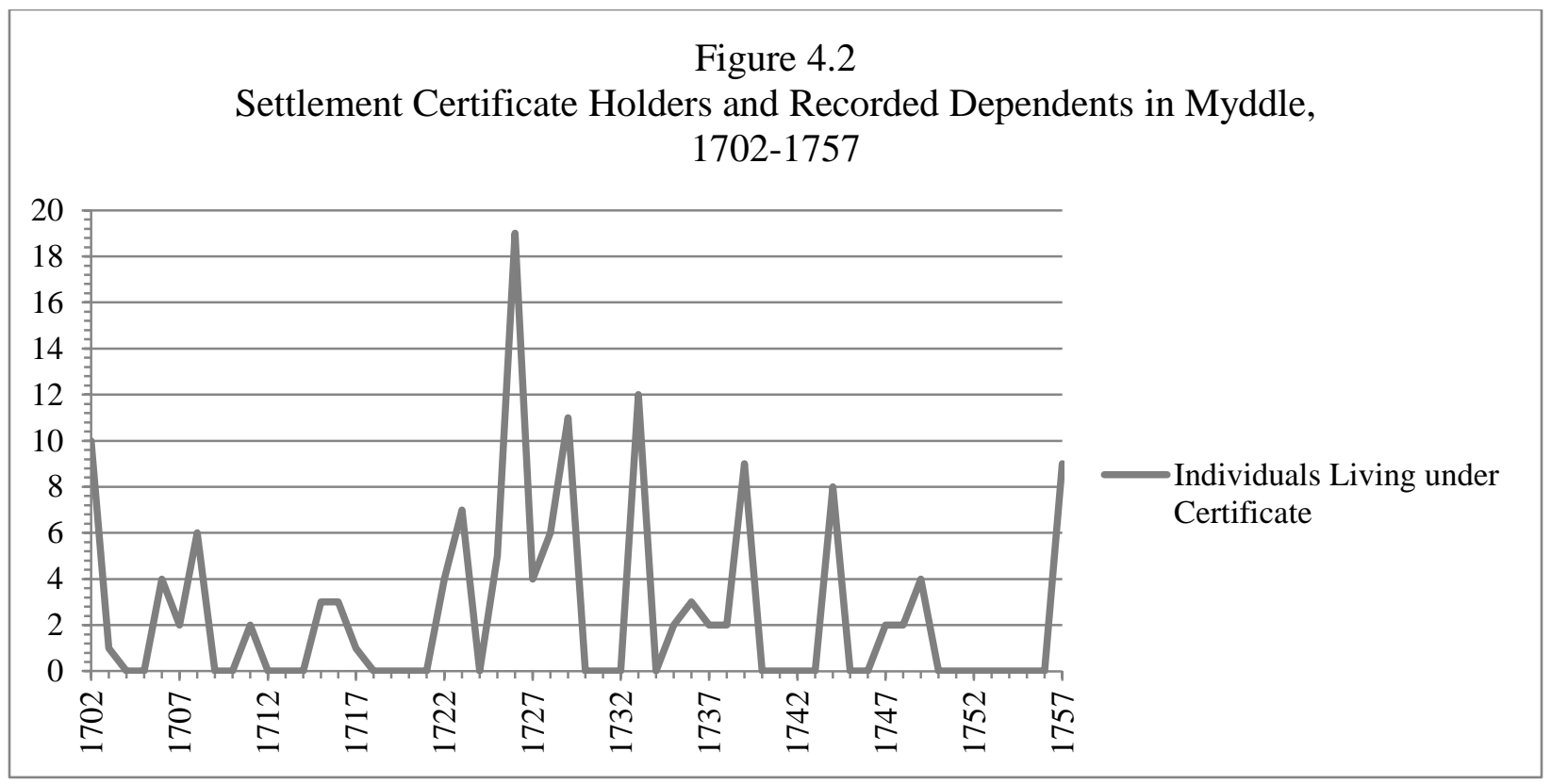

On the whole, these settlement certificates relate to individuals who came from nearby Shropshire parishes such as Ellesmere, Loppington, Wem, Baschurch, Preston Gubbals, and various parishes within the local market town of Shrewsbury, a geographical spread mirrored in the parish's settlement examinations and removal orders. Several certificates were issued by the chapelry of Hadnall, an ecclesiastical subdivision within the parish of Myddle. One man, Joseph Grindley, held a certificate issued in 1722 by Hankelow, a parish in the neighboring county of Cheshire. This basic geographical range is characteristic of Myddle's poor law documentation in general, as many of the individuals reflected in it are from neighboring villages and towns. They were local, but would have been nevertheless regarded as "strangers" both under the poor laws and according to the manner in which the parish - the fundamental unit of the early modern English community - was envisioned.

As is the case with other English parishes of this period, the vast majority of Myddle's certificate holders were men, with just three issued to women. Two of these were single and thus unburdened, that is, without children. One, Margarett Foulk, who was issued a settlement 
certificate from the Shropshire parish of Preston Gubbals in 1726, was burdened with four children. $^{80}$

Of the men, most were burdened, with forty cases mentioning wives and/or children and just three lacking such details. It is possible that some of these men did in fact have families, but as with Myddle's settlement examinations, this information simply went unrecorded. Since most male certificate holders had families, it is likely that if all of the individuals reflected indirectly by these certificates were taken into account, the actual number was easily closer to 100 to 150 individuals who lived and worked in Myddle but were not considered a part of the local community over the roughly 55 -year period covered by extant documentation. As calculated by Hey, the population of the parish, excluding the chapelry of Hadnall, numbered about 450 in $1700 .^{81}$ Using both the above figures and Hey's, the largest amount of certificate holders, nineteen, was recorded in 1726 . Recognizing that this number is almost certainly an underrepresentation, it suggests that in that year at least 4.2 per cent of Myddle's population was living under certificate.$^{82}$ In fact, such calculations are not out of line with Hey's study of Myddle, which shows that from the 1630s on, immigration to the parish increased and laborers made up a larger proportion of the population, stressing the parish's resources in the closing years of the century. ${ }^{83}$ Moreover, although those reflected within this set of documents shows the extent of Myddle's resident, non-settled inhabitants, these are only those individuals who

\footnotetext{
${ }^{80}$ There is strong evidence that Margarett was the widow of John Foulkes, who was examined in 1717/8 and again in 1723. These documents record that Foulkes's wife's name was Margaret and that John had previously lived in Preston Gubbals. Settlement Examinations, 1717-1808, P201/L/3 (Shropshire Archives, Shrewsbury).

${ }^{81}$ If Hadnall is taken into account, Hey estimates the population to have been roughly 600 in the latter years of seventeenth century. David G.Hey, An English Rural Community, 42-43; Richard Adair, Courtship, Illegitimacy, and Marriage in Early Modern England (New York: Manchester University Press, 1996), 123.

${ }^{82}$ For comparison, records for 1729 noted eleven certificate holders ( 2.4 per cent), and during 1733 twelve certificate holders ( 2.7 per cent) were recorded.

${ }^{83}$ An earlier wave of immigration had occurred in the 1580s and 1590s. Hey, An English Rural Community, 178.
} 
were documented and whose papers happened to survive. Therefore, it is probable that the actual population of such individuals was in reality higher. Paul Slack, for instance, estimates that during the eighteenth century, as many as one-fifth of a parish's population might not have been settled, and Joanna Innes notes that about one-quarter of the residents of Norwich and Stratford-upon-Avon in the eighteenth century were unsettled. ${ }^{84}$

Although parish settlement records are key sources for investigating both the relative frequency of itinerancy and general size of a parish's population of resident aliens, parish registers are another resource in which occasional references to such things appear. Myddle's burial register data suggest how many of the parish's inhabitants might have been poor. For example, Myddle's burial records for the years from 1600 to 1800 record the interments of several paupers and itinerants (see Figure 4.3 below). ${ }^{85}$ Although dependent on Myddle's total population during those years, when looked at in conjunction with some of the conclusions within Hey's study and Myddle's various types of settlement records, these numbers suggest that the parish had increased pauper burials precisely during the period when wealth disparity in the parish was increasing. ${ }^{86}$ During these years and out of 185 total pauper and itinerant burials, which includes all those described as paupers, poor persons, foreigners, peregrini/peregrinae, strangers, travelers, vagrants, vagabonds, wandering persons, sojourners, or as being on relief or "from the workhouse," there are descriptive instances of six individuals whose names were unknown. Moreover, there are examples of ten people noted as strangers or foreigners and six as travelers, sojourners, vagabonds, or wandering persons. In all, 163 individuals were described as

\footnotetext{
${ }^{84}$ Slack, 30; Joanna Innes, "The 'Mixed Economy of Welfare' in Early Modern England: Assessments of the Options from Hale to Malthus (c. 1683-1803)," in Charity Self-Interest and Welfare in the English Past, ed. M. J. Daunton (New York: St. Martin's Press, 1996), 145.

${ }^{85}$ Registers of Myddle, passim.

${ }^{86} \mathrm{Hey}$, An English Rural Community, 5-6, 230-31.
} 
paupers or poor persons and four individuals are mentioned as either being on parish relief or coming from the workhouse.

Figure 4.3

Pauper and Itinerant Burials in Myddle, 1600-1800

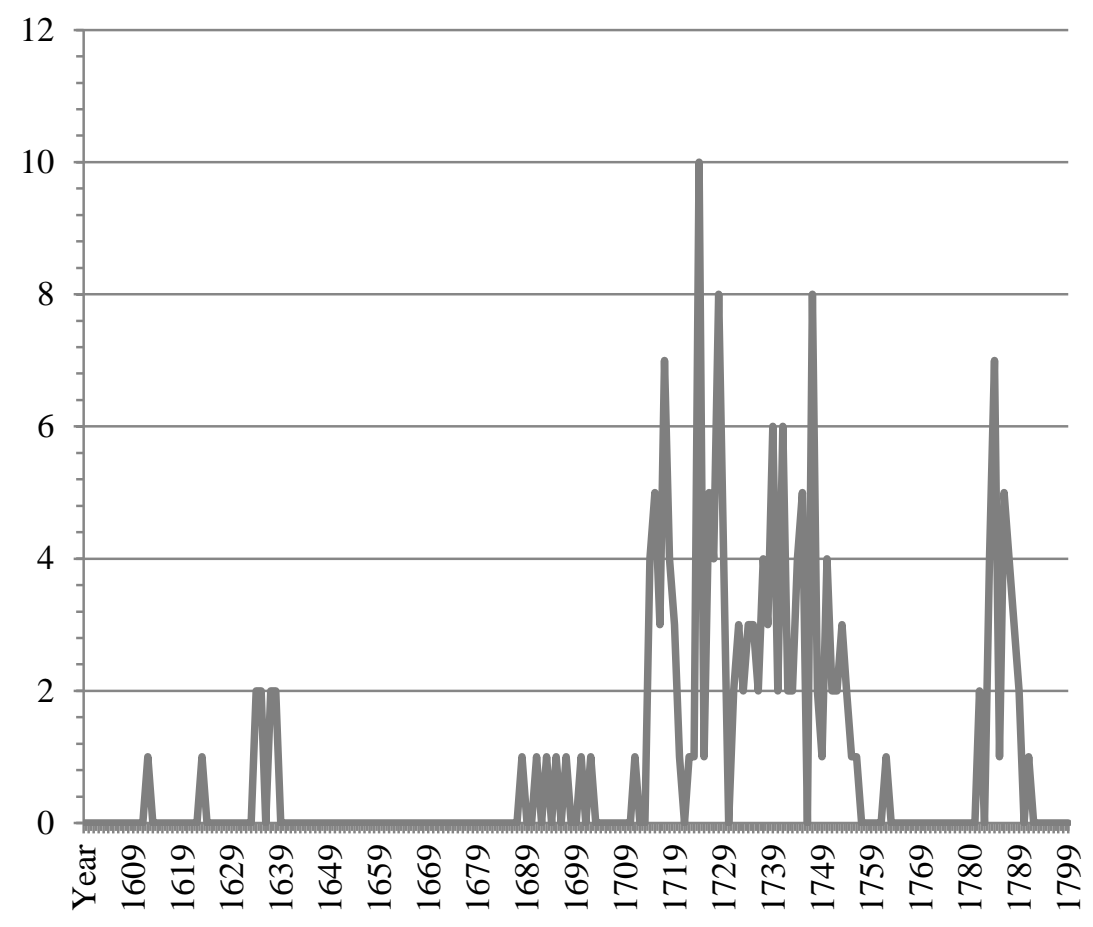

Pauper and Itinerant Burials

Also among these was "ye wyfe of Adam Peplo, laborer [. . .], his dwelling is unknowne, was found dead [...] one [sic] the King's highe way neere Marton." ${ }^{87}$ Local people estimated that Margaret Peplo had starved to death, and she was buried 12 February 1623/4. Other examples include "Baldwine," who was simply recorded as "a Stranger" and buried 17 July 1698, and Sarah, the daughter of Thomas Williams, "a wandering person," who was buried 29 October $1694 .^{88}$ Three individuals were buried about whom nothing was known: a poor man who "dy'd upon his journey" and was buried 6 September 1727; a "Traveller" who "dy'd at Harmere [Harmer] Hill" and was interred that same winter, on 20 January 1727/8; and a "strange

\footnotetext{
${ }^{87}$ Registers of Myddle, 81.

${ }^{88}$ Registers of Myddle, 109, 116.
} 
woman" who was also noted as having been dumb was laid to rest 10 February $1763 .{ }^{89}$ That these nameless and otherwise undocumented individuals appear in the documentary record in such mere snippets at all is a testament to how little is known about their lives.

\section{Conclusions: Settlement in Myddle during the Eighteenth Century}

Read from the point of view of parish officials, the above sources illustrate the threat represented by the poor to not only the parish's limited resources but also to the entire social order, which in this period revolved heavily around property ownership and labor as well as values like industriousness and respectability. On the other hand, read from the point of view of their subjects, these accounts help uncover the diverse experiences of poverty among various groups of people, including single male and female agricultural laborers, married men and women, families, the elderly, and children. In short, although all of these types of paupers presented a unified pecuniary danger to the parish, the response was differential. Most markedly, gender and marital status formed key dynamics in the disparate treatment of single male laborers versus women and married men with families.

Myddle's settlement documentation, parish registers, and Gough's writings also reveal the prejudices inherent in determining settlement as well as managing the resources of the parish. In the process, the conceptual borders at which belonging was questioned and cross-examined are similarly uncovered through the poor laws' concept of settlement. This meant that those considered more likely to become chargeable to the parish - women, particularly widows and single women with children, and men with families - had their settlement within the community interrogated more strongly than other members of the parish. At the same time, single men came under suspicion to a lesser degree, underlining the importance placed upon male labor and a

\footnotetext{
${ }^{89}$ Registers of Myddle, 168, 235.
} 
gendered power structure that recognized men as heads of, and providers for, the household, and women and children as their dependents. In these ways, settlement was unstable, and could change, depending on whether an individual was male or female, old or young, married or single, or as the documents so often put it, had a "large burden of children." The boundaries of belonging were set by parish officials, but they could be surprisingly fluid in that they were determined by the exact circumstances of the person whose settlement in the parish was being examined.

Also revealed in these documents are the cataloguing of the itinerant life of unmarried agricultural laborers, the hazards experienced by unmarried mothers, and the instability of family life that characterized - and still characterizes - poverty. Part of this insecurity was due to the nature of poverty itself, but the evidence shows how local officials, through their interpretation of the poor laws and managing the movements of such families, contributed as well. It would be tempting to argue that these sorts of people were not terribly numerous and never made up a significant portion of the population of Myddle. However, the documentary record shows that they were there, "travelling about" and "making shift," of the parish but not part of it. Despite the fact that they were not without agency and could at times work the system to their own ends, all of these people were ultimately weighed down by their own burdens - of class, sex, and age and their belonging often determined by others. 
CHA P T E R 5: M Y D D LE'S "S P A R R O W S ": I L L E G I T I A C Y A N THE POOR LA W SYSTEM

\section{Introduction}

The difficulties associated with studying illegitimacy are numerous. In terms of reconstructing its prevalence in early modern England, historians are forced to rely on local and parochial records, principally court records, parish registers, and poor law documentation. The impediments that apply to the reconstruction of the lives of the illiterate masses are also applicable to an accurate assessment of bastardy. The primary difficulty revolves around the indirect, imperfect, and incomplete recording of the stories of the lower classes by elites. Mobility too is problematic. The poor especially, and poor mothers of illegitimate children in particular, are prone to brief appearances in the historical record, followed by an enduring silence. This habit famously moved Peter Laslett and Karla Oosterveen to frustratingly compare such ephemeral women to the flight of the sparrow, which moves through the night into a building flooded with light, only to return to the obscurity of darkness once more, never to be seen nor heard from again. ${ }^{1}$

Bastardy was yet another aspect of early modern poor law administration in which money and morality were intertwined. Illegitimacy was explicitly linked to the concept of settlement, as a child's parish of birth dictated the parish responsible for his or her relief. The parish, therefore, had a vested interest in offloading this responsibility through a variety of means, which it often attempted to do. These methods included forcing the father, if born in a different parish, to marry the mother in order to ensure the child's legitimacy, and thus the family's settlement,

\footnotetext{
${ }^{1}$ Peter Laslett and Karla Oosterveen, "Long-Term Trends in Bastardy in England: A Study of the Illegitimacy Figures in the Parish Registers and in the Reports of the Registrar General, 1561-1960," Population Studies 27, no. 2 (July 1973): 284.
} 
within the father's parish. ${ }^{2}$ In its characterization as a social problem bastardy also possessed important legal and social implications and both strained parochial finances and influenced ideas of belonging within the parish.

These tensions also meant that while fathers of illegitimate children were seen as more financially culpable, mothers were held more morally responsible. Even with the enacting of the New Poor Law in 1834 - and the consequent changing of both the times and the nuance of the arguments - the legislation and administration of the poor laws remained particularly connected with the morality of poor women in general and particularly their bearing of illegitimate children. ${ }^{3}$ As well, the fact that men possessed most of the economic and social control in society at the time had important implications. First, this meant that the regulation of bastardy at the local level though poor law administration was gendered. The documents left behind reflect the fact not only that men managed and controlled the record-making process, but also reveal the importance parish officials placed on holding men financially accountable for fathering illegitimate children in need of parish support. Another effect was that while the fathers and mothers of illegitimate children both experienced punishment and shame, their violations of societal expectations meant that they suffered these in different ways. Another central ingredient in this basic moral system was class, which also moderated attitudes about illegitimacy in important ways.

However, bastardy was much more than a simple moral issue, particularly after 1750 when illegitimacy rates across the nation appear to have increased. ${ }^{4}$ This upsurge, although well

${ }^{2}$ W. E. Tate, The Parish Chest: A Study of the Records of Parochial Administration in England, 3rd ed. (New York: Cambridge University Press, 1969), 218.

${ }^{3}$ Susan Zlotnick, "'The Law's a Bachelor': 'Oliver Twist,' Bastardy, and the New Poor Law," Victorian Literature and Culture 34, no. 1 (2006): 138.

${ }^{4}$ Tate, 215. 
known and documented, as Belinda Meteyard summarizes, has spurred much debate over its exact causes. For example, much attention has been paid to the passage of Lord Hardwicke's Clandestine Marriage Act of 1753, which in its redefinition of what constituted a legal marriage, may well have resulted in some births being classified as illegitimate that would have been labelled legitimate in the early half of the century. ${ }^{5}$ Whether or not this is strictly true, and on this point Meteyard judges the effects of Lord Hardwicke's Marriage Act to have been a key ingredient in pushing up the recording of illegitimacy, the issue illustrates how concepts like illegitimacy and marriage were unstable constructs that could change over time. ${ }^{6}$

The survival of several different types of sources for Myddle makes possible an evaluation of both the management of illegitimacy through the poor law system as well as local attitudes to such incidents. First, it is within the parish register that is often the sole place where such births are recorded. ${ }^{7}$ These types of births are typically fairly easy to identify in parish registers, due to their deviation from the recording of legitimate children. They are typically indicated by various terminologies in both English and Latin, such as "child of the people/ populi", "bastard," "base-born," "illegitimate," "merry begot," "nothus," "scapebegotten," "viciatus," in addition to myriad local variations and abbreviations. ${ }^{8}$ Likewise, the absence of the father's name, use of the mother's surname, inclusion of the surnames of both parents, or

\footnotetext{
${ }^{5}$ The new law, which took effect in 1754 , specified that in order for a marriage to be considered legal, it must take place in a church, be entered into the parish register and be signed by the bride and groom, parental consent was required for all individuals under the age of twenty-one, and marriage was thereafter to be a matter that fell under the jurisdiction of secular, and not church, courts, meaning that clergy could be punished for disobeying any part of the Act. Belinda Meteyard, "Illegitimacy and Marriage in Eighteenth-Century England" Journal of Interdisciplinary History 10, no. 3 (Winter 1980): 479-87.

${ }^{6}$ Here, Meteyard's conclusions are in line with studies of medieval marriage. See Ruth Mazo Karras, Unmarriages: Women, Men, and Sexual Unions in the Middle Ages (Philadelphia: University of Pennsylvania Press, 2012), 1-24; Meteyard, 487-89. See also Ginger S. Frost, Living in Sin: Cohabiting as Husband and Wife in Nineteenth-Century England (New York: Manchester University Press, 2008), 9.

${ }^{7}$ This is albeit rather indirect evidence, and is based on the documenting of christenings with the parish.
} Tate, 219.

${ }^{8}$ Tate, $310-22$. 
insertion of the term "reputed " are clues to a child's illegitimate status. Using Myddle's parish registers, which are relatively complete except for a thirty-five year gap from approximately 1646 to 1681, these conventions allow for an estimation of Myddle's illegitimacy rate throughout the early modern period.

Second, the references to illegitimacy within Richard Gough's The History of Myddle provide a counterweight to numbers-driven parish register data. Gough's text provides crucial evidence for attitudes about bastardy, in addition to estimations of its relative frequency. Study of Gough's writings on this subject matter also opens up inquiry into cultural attitudes, a key feature of settlement, a focus of previous chapters and an important area of poor law administration.

The History of Myddle has its limits as a historical source, both in bias and periodization, stemming from Gough's involvement in poor law administration in the parish. Also, since the text was written in 1700-1701, the whole of the eighteenth century is omitted. A small collection of bastardy examinations and bonds for Myddle sits squarely within this period (1710-1778), covering the years that postdate Gough's writings. Both bastardy examinations and bonds resulted from the interviewing of an unwed mother by local officials, usually justices of the peace or parish overseers of the poor. Bastardy examinations were conducted in order to elicitsometimes under duress - the putative father of a woman's illegitimate child. The latter type of document, essentially a bond of indemnification, represented an effort to then consign responsibility for the financial support of an illegitimate child on the shoulders of the father, and absolve the parish from any financial obligation for the bringing up of the child. Bastardy bonds often reflected an attempt by the parish officials of the parish where the mother was to give birth (which would upon delivery become the child's parish of settlement), to ensure financial support 
from the putative father. ${ }^{9}$ These documents add weight to Gough's conclusions about the proclivity for bastardy amongst certain segments of the population.

Due to the limitations of all of the above sources, both their incompleteness and prejudices, what follows is an unavoidably impressionistic and tentative portrait of Myddle's "sparrows." The general picture is also a one-sided one, and from the vantage point of local elites. Despite these drawbacks, a few observations can nonetheless be made. Although the illegitimacy rate in Myddle only stood at about three per cent from c. 1600-1800, a proportion which seems to mirror that in most other rural parishes of the time, Gough's writings reveal great concern with the matter, as he describes a number of families in Myddle with an inclination toward bastardy, something also hinted at in the parish's extant bastardy examinations and bonds. ${ }^{10}$ Gough often connects bastardy with other negative character traits, such as drunkenness, idleness, and profligacy. As well, it attracted his greatest condemnation when the resultant child ended up supported through the parish rates.

Gough's attitudes to bastardy were also gendered, and fathers were more so associated than mothers with the financial costs of bastardy. Such men, particularly upper-class property owners, were criticized for how the offense affected their estates, for example. Women, on the other hand, particularly those of the lower-classes, were more likely to face censure for their lewdness, moral laxity, and lack of self-control. All of these sources therefore uncover that while illegitimacy was never a large problem in Myddle, something that was true even after 1750 when illegitimacy rates rose elsewhere, it was nevertheless an issue that attracted a fair amount

\footnotetext{
${ }^{9}$ Not infrequently the parish in question was the residence of the woman's own father and family. Thus, at least in some cases, this choice of locale represented her own selection of where she wished to give birth. K. D. M. Snell, Parish and Belonging: Community, Identity and Welfare in England and Wales, 1700-1950 (New York: Cambridge University Press, 2006), 146.

${ }^{10}$ As calculated from parish register data, illegitimate births made up 2.98 per cent of all recorded baptisms in the parish of Myddle from 1600 to 1800. W. P. W. Phillimore, ed., Registers of Myddle, Shropshire Parish Registers, Lichfield Diocese, vol. 19 ([Shropshire]: Shropshire Parish Register Society, 1931); Tate, $214-15$.
} 
of anxiety within in Gough's writings. Equally important, it produced apprehensions and expectations that were heavily influenced by both class and gender.

\section{Bastardy and the Poor Laws}

For the purposes of this study illegitimacy is defined as the birth of a child to parents who were unwed at the time of the child's birth and stayed unmarried. It does not, therefore, include instances of "pre-nuptial pregnancy," whereby the parents married either after conception or soon after the child was born. ${ }^{11}$ Nor does it take into account cases where a couple cohabited, enjoying all of the basic features of marriage without a church ceremony solemnizing the union, and whose children's births local clergymen might be inclined to record as "legitimate." ${ }^{12}$ In these ways, the evidence portrays an inevitable under-recording of illegitimacy within Myddle. Moreover, due to the nature of the records, the focus in Myddle's parochial records is on the poor, as these documents refer to cases of illegitimate children who were likely to become chargeable to the parish. Gough's writings do provide an adjunct to this focus, however, commenting as they do on cases of illegitimacy in other levels of Myddle's society.

As a legal matter, illegitimacy eventually came to fall under two jurisdictions. For men and women deemed guilty of the offense, the fathering and bearing of bastard children had been seen as a moral issue by church courts since the medieval period. Church courts could mandate that the parents do penance for the sin of fornication or pay a fine, while the penalties ordered by secular authorities involved public shaming and sometimes whipping, punishments that were more often meted out to women rather than men. ${ }^{13}$ Attitudes began to change - and become

\footnotetext{
${ }^{11}$ Laslett and Oosterveen, 269-70.

${ }^{12}$ Meteyard, 485.

${ }^{13}$ Alexandra Shepard, "Brokering Fatherhood: Illegitimacy and Paternal Rights and Responsibilities in Early Modern England," in Remaking English Society: Social Relations and Social Change in Early Modern England, ed. Steve Hindle, Alexandra Shephard, and John Walter (Rochester, New York: The Boydell Press, 2013),
} 
more severe - in the late sixteenth century when anxieties developed over the problems of vagabondage and the poor's mobility. ${ }^{14}$ For example, these fears, combined with the establishment of a parish system of poor relief set up in the early seventeenth century, added new impetus to concerns over illegitimate children who might become chargeable to the parish. ${ }^{15}$ Thus, the legal division that developed was such that the church courts regulated illegitimacy as it related to sexual immorality, whereas secular courts tended to handle it in relation to vagrancy legislation and poor relief, concentrating on the financial support of illegitimate children as well as the castigation of the reputed parents. ${ }^{16}$

The Poor Law Act of 1576 marked the first secular law dealing with illegitimacy, specifying that abandoned illegitimate children were to be supported from either public or charitable funds. As well, local justices of the peace could punish both parents and hold them responsible for a child's support via legal order. Failure to comply could result in imprisonment. Though much of the law highlights the financial costs of illegitimacy, in a reflection of the dualistic legal systems that regulated it, the text notably refers to the offense as a violation of both "God's law" and "man's":

Concerning bastards begotten and born out of lawful matrimony, (an offence against God's law and man's law,) the said bastards being now left to be kept at the charges of the parish where they be born, to the great burthen of the same parish, and in defrauding of the relief of the impotent and aged true poor of the same parish, and to the evil example and encouragement of lewd life;" it is (not ordained or enacted) "that two justices of the peace, (whereof one to be of the

50; Mark Bailey, The Decline of Serfdom in Late Medieval England: From Bondage to Freedom (Woodbridge, Suffolk: The Boydell Press, 2014), 41.

${ }^{14}$ Walter J. King, "Punishment for Bastardy in Early Seventeenth-Century England," Albion: A Quarterly Journal Concerned with British Studies 10, no. 2 (Summer 1978): 134.

${ }^{15}$ R. H. Helmholz, "Harboring Sexual Offenders: Ecclesiastical Courts and Controlling Misbehavior," Journal of British Studies 37, no. 3 (July 1998): 264-65.

${ }^{16}$ Martin Ingram, Church Courts, Sex and Marriage in England, 1570-1640 (New York: Cambridge University Press, 1994), 152-53; Bailey, 41. 
quorum, in or next unto the limits where the parish church is, within which parish such bastard shall be born, (upon examination of the cause and circumstance,) shall and may by their discretion take order, as well for the punishment of the mother and reputed father of such bastard child, by charging such mother or reputed father with the payment of money weekly, or other sustenation for the relief of such child, in such wise as they shall think meet and convenient; and if after the same order by them subscribed under their hands, any of the said persons, viz. mother or reputed father, upon notice thereof, shall not for their part observe and perform the said order, that then every such party so making default in not performing the said order, to be committed to the ward to the common gaol, there to remain without bail or mainprize, except he, she, or they shall put in sufficient surety to perform the said order, or else personally to appear at the next general sessions of the peace, to be holden in that county where such order shall be taken, and also to abide such order as the said justices of the peace, or the more part of them, then and there shall take in that behalf (if they then and there shall take any); and that if at the said sessions the said justices shall take not other order, then to abide and perform the order before made, as is abovesaid. ${ }^{17}$

However, when dealt with as a secular matter, in practice punishment was generally structured in such a way that men were primarily held financially responsible, while women were morally punished. For instance, Alexandra Shephard finds that if the child were likely to become chargeable to the parish, "the mother was to be whipped and committed to the house of correction for one year and, when possible, the 'reputed' father was to be bound to save the parish harmless from all costs associated with the child's upbringing and could be gaoled until he provided sufficient security to do so." ${ }^{18}$ Moreover, the differing responsibilities of the ecclesiastical courts and local justices of the peace were such that, according to Keith Wrightson:

[t]he essential concern of the church courts was to maintain the boundaries of permitted behaviour and to enforce, by the imposition of public penance, the public reaffirmation of the norms which had been breached. The justices on the other hand were primarily concerned with the more tangible challenge of a

\footnotetext{
17"An Act for the Setting of the Poor on Work, and for the Avoiding of Idleness (18 Elizabeth c. 3)," quoted in Richard Burn, Joseph Chitty, and Thomas Chitty, eds. The Justice of the Peace and Parish Officer, vol. 4 (London, 1831), 360.

${ }^{18}$ Shephard, 50-51.
} 
bastard birth; to see to the maintenance of the child without, if possible, burdening the parish; to clarify responsibility when necessary; to adjudicate conflicts aroused by a bastard birth between neighbours or parishes. ${ }^{19}$

Although there is evidence that the above punishments for bastardy were under-enforced, class was an important factor; as seen in the above excerpt from the 1576 Poor Law Act referencing "the great burthen" it posed to the parish, the genuine worry over illegitimacy was economic. $^{20}$ For example, Walter J. King finds that in seventeenth-century Lancashire the real concern over bastardy related to its costs "because it lengthened relief rolls and strained local budgets," a paradigm that appears to hold for most rural parishes of the period. ${ }^{21}$ While there was arguably some sense of moral guilt in the committing of bastardy - again, the 1576 Act dubbed the transgression a crime against laws both divine and human - such legal punishments were only for those who relied upon the parish for their support and maintenance. In this way, punishment for illegitimacy was therefore class dependent. Individuals who could support their own illegitimate children, and thus did not rely upon the larger community for sustenance, received a legal pass - and sometimes a moral one. ${ }^{22}$

Although the parish used a variety of arrangements to house and financially support bastard children, efforts to take care of them began with the child's family. The pursuit for financial support of illegitimate children originated with the child's parents and wider family relations outwards to the larger community, and finally came to rest with the parish poor law apparatus. First, payments were sought from one or the other of the child's parents, depending

\footnotetext{
${ }^{19}$ Keith Wrightson, "The Nadir of English Illegitimacy in the Seventeenth Century," in Bastardy and Its Comparative History, ed. Peter Laslett, Karla Oosterveen, and Richard M. Smith (Cambridge: Harvard University Press, 1980), 178.

${ }^{20}$ Walter J. King, 135, 138.

${ }^{21}$ Walter J. King, 139.

${ }^{22}$ Ivy Pinchbeck and Margaret Hewitt, Children in English Society, vol. 1 (Toronto: University of Toronto Press, 1969), 206-7.
} 
on which parent cared for the child, or both the mother and father if the child was lodged with a non-parental third party. Next, extended family members were sought if the parents were dead, absentee, or too poor themselves to contribute to the support of the child. Additionally, the paternal grandfather (the reputed father's father) and sometimes even local constables, both of whom were sometimes adjudged as having some blame in allowing the parents to abscond, could be held responsible for the child's financial support. Seen in this way, bastardy was a misdeed that touched the entire community, especially given that even those who had merely boarded unwed pregnant women could be held responsible. As with the larger issue of pauper maintenance and support, the last resort was the parish, an entity that could step in and house, provision, and sometimes eventually bind the child out as an apprentice, all by way of the parish rates. $^{23}$

In comparison to other features of the poor laws, illegitimacy was perhaps the matter in which women's correlation with the moral sphere was made the sharpest, and given the difficulties inherent in determining a child's father with certainty, the mother's reputation could be critical in establishing paternity. ${ }^{24}$ For example, in King's aforementioned study, while economic factors were a driving force in imprisonment rates for moral offenses, which actually fell throughout the seventeenth century, there were important ideological considerations as well. Importantly, ideas about bastardy reflected both differing expectations of male and female behavior:

Probably everyone in the seventeenth century would have agreed with the justices who committed to the house of correction in Preston (Lancs.) Alice Robinson of Manchester for having four bastards 'by maryed men and others,' and Thomas

\footnotetext{
${ }^{23}$ Walter J. King, 131-32.

${ }^{24}$ Thomas Nutt, "The Paradox and Problems of Illegitimate Paternity in Old Poor Law Essex," in Illegitimacy in Britain, 1700-1920, ed. Alysa Levene, Thomas Nutt, and Samantha Williams (New York: Palgrave Macmillan, 2005), 114.
} 
Greenhalgh of Atherton for fathering seven bastards. But they would not have agreed on whether male and female were equally guilty or whether the unwed father and mother should be punished similarly. ${ }^{25}$

At the local level, quarter sessions records contain examples of efforts to reduce the costs associated with the maintenance of illegitimate children by making the reputed father either pay a lump sum, or more commonly, a weekly fee to the child's parish of settlement. But, this is not to say that officials only ever associated the father with financial support: there are instances of magistrates holding both parents responsible for reimbursing the parish for a child's maintenance; however, this was usually in cases where the mother was not able - either through inclination or ability - to take care of the child. However, even in cases of a combined maintenance order, the mother's payment was usually much less than the father's. ${ }^{26}$ In such ways, women's complex connection with morality was manifested.

The relationship between woman and the moral sphere, a theme also common in Gough's writings about illegitimacy, is colorfully expressed in the late seventeenth-century ballad, "A Looking-Glass for Lascivious Young Men: Or, the Prodigal Son Sifted." This traditional song tells the tale of a wayward son who returns home and is made to confess to his various misdeeds when his parents place him in a sieve and "sift," or shake, him:

The Old Folks took him to task, and Hoisted him into a Sieve; Where they did many questions ask, but not account he wou'd give.

They Sifted him o're and o're, at last they made him confess; And first came out a strapping Whore, her name it was bouncing Bess.

\footnotetext{
${ }^{25}$ Walter J. King, 130.

${ }^{26}$ Pinchbeck and Hewitt, 210-12.
} 
This slut she had suck'd him dry, of all his Mony and Wit:

Which made him now to roar and cry, and look as he were besh------

They give him the other shake. and out comes Eight or Nine more; Which made them both such pains to take, until they siifted $[$ sic $]$ a score.

Next comes a young Bastard forth, at which the old Woman starts; It was a lumping penny-worth, a perfect buddle of Farts.

With that the old Man took heart, and said to his frowning Wife;

Let's sift him throughly e're we part, [si]nce we shall have Grandsons rife.

No no, then answer'd the Dame, this one is enough for me; For it wou'd be a burning shame more bastardly Babes to see. ${ }^{27}$

Here, the son's improper relationship with "bouncing Bess" is the first physical evidence of his immorality. The immodest Bess is then followed by others of her kind before the parents' illegitimate grandson, a mixed blessing, appears. Tellingly, Bess is promiscuous but also greedy. Though their first inclination is to shake their son some more in order to gain more grandsons, it is the mother who remarks that such children would be the family's disgrace. As the son is

27"A Looking-Glass for Lascivious Young Men: Or, the Prodigal Son Sifted Wherein Is Plainly Discovered the Follies and Extravagancies of a Young Man ..." ([London], 1689-1692), Magdalene College, Pepys Library, Pepys Ballads 2.72, English Broadside Ballad Archive (EBBA), University of California Santa Barbara, EBBA ID: 20696, accessed 16 February 2016, http://ebba.english. ucsb.edu/ballad/20696/image. 
further "sifted," a lace cravat, fringed gloves, dice, and cards appear, all further evidence of his wasteful ways.

Undoubtedly, the financial resources available to a parish were important factors in the management of bastardy within a local community, but so was gender. There was a pervasive double standard that held female infidelity as producing greater harm to the family. ${ }^{28}$

Accordingly, punishment for bastardy was both divergent in motive and character for men and women, whereby "[f]emales were punished for bastardy; males were punished for failing to provide sureties to free parishes of the costs of maintaining the children." ${ }^{29}$ Because the father would be more likely to provide financial support for a child's upbringing, it might have been the case in places where women were imprisoned for bastardy more often than men that officials reasoned that it was better to incarcerate an illegitimate child's mother. In other words, it was more practical - at least in the eyes of the parish - for the mother to bear the brunt of moral punishment because even if she were imprisoned, financial support could still be sought from the reputed father. ${ }^{30}$

If both men and women were linked to the material in the committing of bastardy, these associations were manifested in different ways. The fundamental difference was that whereas siring a bastard created a financial responsibility, bearing one demonstrated corporal evidence of moral transgression. ${ }^{31}$ Studies of court cases involving bastardy show that when compared to the

\footnotetext{
${ }^{28}$ Pinchbeck and Hewitt, 215-16.

${ }^{29}$ Walter J. King, 140.

${ }^{30}$ Walter J. King, 144.

${ }^{31}$ Laura Gowing makes this distinction very clear in her discussion of the language used to describe bastardy: "The most personal effects of whoredom were those it visited upon the body: bastardy and disease. Defamers used both to insist that whoredom left permanent marks on the bodies of men and women. In the language of insult, pregnancy and bastardy served more as proofs of whoredom than offenses in themselves. Their meaning differed for women and for men. When men were accused of begetting illegitimate children, the principal consequence was perceived as the financial results of abandonment." Laura Gowing, Domestic Dangers: Women, Words, and Sex in Early Modern London (New York: Oxford University Press, 1998), 88.
} 
relative lack of guilt men seemed to have in describing their sexual behavior and indiscretions, "women's defamations of men have about them a certain desperation, an awareness of the inequality of penalties for sex and the unlikelihood of bringing a man to account for his sexual indiscretions except through the financial responsibilities of bastardy." ${ }^{32}$ Certainly, legislation was meant to curb any financial burden a parish might incur in trying to support an illegitimate child, but there existed a moral dimension as well. Although mitigated in complex ways by class, this vested in women a sexual morality that rendered their responsibility to engage in sexual relationships solely within the confines of marriage an important regulator of family honor. $^{33}$

Moreover, women were in fact deeply affected by poverty: estimates are that at a given time, about half of women would have been considered poor and about two-thirds of all women would experience poverty in their lifetimes, many of them facing life-cycle poverty related to widowhood, sickness, or old age. ${ }^{34}$ Likewise, although vagrancy was traditionally seen as a male condition, at least one-third of the individuals arrested for the crime were women. ${ }^{35}$

In terms of the poor laws themselves, poor pregnant women were some of the most "[s]ocially threatening migrants." ${ }^{36}$ Within the communal context, the discouraging of parish residents from taking in pregnant boarders, who were regarded as at risk of absconding and leaving behind their infants for the parish to support, appears to have been a common

\footnotetext{
${ }^{32}$ Gowing, 75.

${ }^{33}$ Isabel V. Hull, Sexuality, State, and Civil Society in Germany, 1700-1815 (Ithaca, New York: Cornell University Press, 1996), 169; Karras, 97-98.

${ }^{34}$ Patricia Crawford and Laura Gowing, eds. Women's Worlds in Seventeenth-Century England: A Sourcebook (New York: Routledge, 2000), 105.

${ }^{35}$ Crawford and Gowing, 106.

${ }^{36}$ David Hitchcock, "A Typology of Travellers: Migration, Justice, and Vagrancy in Warwickshire, 16701730," Rural History 23, no. 1 (2012): 21.
} 
phenomenon. ${ }^{37}$ All of these dynamics combined to create a desperate situation for the poor mothers of illegitimate children, who also came up against settlement laws in their bid to support themselves and their offspring. In 1656, Katherine Talbott, who stood accused of infanticide at the Northern Assizes, told of her movements from place to place after giving birth to an illegitimate child, from whom she was separated for a time, and how she tried in vain to secure proper support from authorities in Slaidburn, Yorkshire:

So this examinant was constrained to leave and beg with her child from place to place and town to town for relief till about Shrovetide $17^{\text {th }}$ of February last her child was very sick with [illegible] and she lay at Thomas Bidsborrowe's at Great Barugh a pieceman's house there, this examinant saith they can witness that the child was not like to live one hour yet this examinant was forced to go on with it and about the next day to seek relief. And upon the common at the head of the way this examinant sat down with her child and it died in her arms there and she laid it down under a hill side and left it there and acquainted nobody. Since that time this examinant hath wrought for her living by spinning and there as she could get work. ${ }^{38}$

Though Talbott's testimony reveals a particularly distressing existence and no sources survive in Myddle's parish chest documents that are quite as evocative, there are features of her account that would have been common to many of the women who passed through the rural parish, pregnant and unwed. It must be remembered that generalizations are difficult and these women did not function as a "monolithic body, having identical experiences and views of the world." ${ }^{39}$ Still, most of them would have also wandered from place to place, in an attempt to support themselves, with no parish likely eager to accept them because of double burden they

\footnotetext{
${ }^{37}$ Walter J. King reports that in Lancashire even parents were prohibited from lodging their pregnant unmarried daughters. Walter J. King, 138.

${ }^{38}$ Northern Assizes Depositions, PRO, ASSI 45 5/3/94 (29 May 1656); quoted in Crawford and Gowing, 118-19.

${ }^{39}$ Richard Adair makes these comments in pointing out some of the limitations of Laslett's conception of a bastardy-prone sub-society. Richard Adair, Courtship, Illegitimacy and Marriage in Early Modern England (New York: Manchester University Press, 1996), 71.
} 
brought with them of moral stain and cost in terms of parish resources. Another point of commonality between the most desperate of these women would have included a sense of deep unhappiness at the limitations society at the time placed upon them. ${ }^{40}$ An added point, evident from both parish documents and Gough's writings, is that despite the fact that men tended to be more often financially punished for bastardy, due to the strictures of the patriarchal society in which they lived, the mothers of illegitimate children more frequently bore the brunt of the moral shame. $^{41}$

\section{Bastardy in Myddle}

The christenings of bastard children were to be recorded in parish registers. Most of these seem to have been baptized and recorded; however, it is easy to see how itinerant mothers of bastard children could escape documentation. ${ }^{42}$ Even so, despite a certain amount of underrecording pre-1754 that is then set against over-recording in the latter half of the eighteenth century, parish registers remain the primary tool of social historians in measuring the frequency of bastardy. Laslett and Oosterveen find that there was much regional variation regarding illegitimacy, with the West and Northwest, including the counties of Lancashire, Cheshire, Gloucestershire, Herefordshire, and Shropshire, experiencing the greatest incidence. ${ }^{43}$ Indeed, Richard Adair argues a bit further and points out that prior to the Civil War there was so much local variation that generalization is difficult. ${ }^{44}$

\footnotetext{
${ }^{40}$ Adair, 71.

${ }^{41}$ Crawford and Gowing, 142; Karras, 110-11.

${ }^{42}$ David Cressy, Birth, Marriage, and Death: Ritual, Religion, and the Life-Cycle in Tudor and Stuart England (New York: Oxford University Press, 1997), 104.

${ }^{43}$ Laslett and Oosterveen, 276-77.

${ }^{44}$ Adair, 62.
} 
With the above caveats in mind, a survey of bastardy in the Shropshire parish of Oswestry suggests an illegitimacy rate of around four per cent between 1581 and 1810, as calculated from parish register baptismal data. ${ }^{45}$ The data from Myddle is comparable to that of Oswestry, a parish that in fact sat just under fifteen miles away. Up until about 1750, despite its uptick in frequency throughout the seventeenth century, illegitimacy in rural parishes appears to have been somewhat rare. ${ }^{46}$ Therefore, both parishes are generally representative, in that the phenomenon was not overly pronounced in either place, notwithstanding the somewhat higher illegitimacy rates Laslett and Oosterveen uncover in Shropshire as a whole. In Myddle, the rate stood at just under three per cent. ${ }^{47}$ The years from 1600 to 1800 saw the christenings of 2,687 children documented, of whom eighty were identified as illegitimate either through the use of explicit terminology or absence of the father's name. ${ }^{48}$ Nor did illegitimacy rates soar in the period 1750-1800: even when these years are examined in isolation, Myddle's illegitimate births climbed to just four per cent. The latter half of the eighteenth century saw 1,174 documented baptisms. Forty-seven of these were illegitimate. In turn, 1,513 baptisms were recorded during the period 1600-1749, of which 33 were illegitimate, yielding a pre-1750 percentage of 2.18, a variance, but not a dramatic one.

\footnotetext{
${ }^{45}$ However, this figure must be taken as merely as an approximation. In fact, illegitimacy rates have proved notoriously difficult to measure. As Laslett and Oosterveen point out, one of the requirements for an illegitimate birth is that a woman must be unmarried to the child's father, which thus leaves married women giving birth to children fathered by a man other than her husband out of calculation. Laslett and Oosterveen, 262, 263-64.

${ }^{46}$ Tate, 214-15.

${ }^{47}$ More specifically, parish register data show that illegitimate births made up 2.98 per cent of all recorded baptisms from 1600 to 1800 in the parish.

${ }^{48}$ Although the lack of a father's name appears a somewhat uncertain methodology for classifying a birth as illegitimate, this is corroborated by several of such examples in extant bastardy bonds. For instance, the christening of Anne, the daughter of Jane Ellis in 1754 and Alice, the daughter of Martha Higginson in 1761, both lack verbiage related to illegitimacy but neither do they mention the children's reputed fathers. Myddle Parish (Shropshire), Bastardy Bonds, 1710-1778, P201/L/6 (Shropshire Archives, Shrewsbury); Registers of Myddle, $213,230$.
} 
While these figures help provide a snapshot of the frequency of illegitimacy in Myddle, parish register data is not as well suited to communicating the human element to what was also a social problem. This is where Gough's extraordinary narrative helps fill in some of the gaps. As several of the settlement cases outlined in chapter three show, bastardy and settlement were matters intricately bound. This connection is most explicit in the 1669 settlement case involving the abandonment of an infant in Myddle by an unidentified woman. Gough vividly describes the urgent effort mounted by parish officials to find the mother, in an attempt to assign the child's parish of settlement elsewhere and thus safeguard Myddle's financial resources. ${ }^{49}$

Insinuations of illegitimacy also make an appearance in Gough's discussion of the legal troubles associated with Elizabeth Davies, a member of the much-ridiculed Beddow family. Davies was a daughter of Humphrey Beddow, but Gough implies that Elizabeth herself was illegitimate through the use of her mother's surname to describe her. He then labels her as both "idle" and "wanton," suggesting that immoral character traits - in this instance indolence and promiscuity - went hand in hand. ${ }^{50}$ It is clear that Gough regards bastardy as interconnected with other moral defaults, reflecting the standard that while bastardy was not necessarily a primary cause of immorality, it nonetheless served as physical evidence for it. ${ }^{51}$ Much as in the narration of the "sifting" of the prodigal son, bastardy constituted a cluster of behavior that helped define ill repute. ${ }^{52}$ Davies, who according to Gough, was "always following after soldiers," eventually became pregnant by one William Gittins, to whom it was claimed she was

\footnotetext{
${ }^{49}$ Richard Gough, The History of Myddle, edited and with an introduction and notes by David G. Hey (New York: Dorset Press, 1986), 251-53.

${ }^{50}$ Gough, 256.

${ }^{51}$ Others have noticed this tendency. For example, Brodie Waddell comments that Gough "readily identified sins such as adultery and lewdness with impoverishment in his illuminating parish history." Brodie Waddell, God, Duty and Community in English Economic Life, 1660-1720 (Rochester, New York: The Boydell Press, 2012), 60.

${ }^{52}$ Gowing, 88 .
} 
married. Thus, the specter of illegitimacy in turn clouds not only her own status but also the birth of her child. ${ }^{53}$

Although Gough does not dedicate as much space to it as other social problems - like drunkenness, to which he refers with extraordinary regularity - he addresses the issue of illegitimacy elsewhere in The History of Myddle. In cataloguing the pedigrees of Myddle's various families, there are plenty of occasions when instances of bastardy are mentioned in a matter-of-fact and less condemnatory way by Gough. For example, that certain individuals had been illegitimate is often straightforwardly stated, as with Jane, the reputed daughter of Thomas Fardoe of Burleton and the wife of Michael Brayne II; Thomas Atcherley Edge, whose use of two surnames was a common indicator of illegitimacy; and Habbakuk Heylin, a bastard son of John Heylin. ${ }^{54}$ There was also Abraham Hanmer, who took in an unnamed bastard son of his brother's. ${ }^{55}$ Although they are less telling about negative views of illegitimacy, the above examples are nevertheless illustrative of its regularity - if not high frequency, according to parish register percentages - in Myddle at this time. And, as in the example of Abraham Hanmer, they show how the support of extended family could be an important element in the raising of such children, the first line of defense in combatting the problem.

In other sections, Gough is more judgmental, a fact that is especially true when the child ended up being supported by the parish. In a small section discussing residents of Myddle who had died during the Civil War in service to Charles I, Gough mentions Richard Chaloner, a bastard son of Richard Chaloner, who was: "partly maintained by the parish, and beeing a bigge lad, went to Shrewsbury, and was there listed, and went to Edgehill to fight [in October 1642] . .

\footnotetext{
${ }^{53}$ Gough, 256.

${ }^{54}$ Gough, 101, 123, 147.

${ }^{55}$ Gough, 245.
} 
. and was never heard of afterwards in this country." ${ }^{56}$ Gough also writes that John Hatchett married a bastard daughter of a Mr. Ditcher, who, although he was rich, "had noe legitimate child" and his wastefulness led him to die a poor man, a common theme in Gough's writings that demonstrates the gendered role for men as good husbandmen and providers. ${ }^{57}$

Gough's writings also illustrate the vulnerability of female servants as well as uncertainties surrounding their morals. In actuality, most female servants were quite vulnerable to sexual propositions and pregnancy at the hands of their masters, his male associates, or family. ${ }^{58}$ The testimony of Elizabeth Hodson, who petitioned the November 1633 Staffordshire quarter sessions for relief after giving birth to her master's grandson, demonstrates such hazards for female servants:

She saith that she dwelt with John Johnson of the parish of Chebsey, father to the said Thomas Johnson whom she accuseth to be the father of the child that she now goeth withall, and father saith that the Saturday sevennight after Stafford fair and being the third day of May she coming into her master's stable with a candle for the men to dress their horses by, and the said Thomas Johnson aforesaid put out the candle and worked his pleasure with her, and after that had to do with her in the kitchen in his father's house, and another time in the hall chimney, and saith that he promised to marry her. ${ }^{59}$

Although evidence such as Hodson's testimony emphasizes the predatory nature of masters, Gough and other sources suggest that often the blame for fornication was laid at the feet of the woman. In The History of Myddle, Gough records how, after the death of his first wife, the wealthy Mr. Twisse of Lower Webscott "marryed againe with his servant maid, a wanton

\footnotetext{
${ }^{56}$ Gough, 72.

${ }^{57}$ Gough, 203.

${ }^{58}$ Crawford and Gowing, 146; Karras, 70.

${ }^{59}$ Staffordshire Quarter Sessions Rolls, Staffordshire RO, Q/SR 213/219; quoted in Crawford and Gowing, $146-47$.
} 
gadding dame, who had neither goods nor good name" called Besse Benion. ${ }^{60}$ When Twisse moved to Eaton, in the parish of Baschurch, Benion "beecame very familiar" with Peter Brayne and afterwards gave birth to a son, Francis, whom Gough natteringly writes "was very like Braine"; nonetheless, "Twisse was very fond of him." ${ }^{61}$ Benion's story is similar to that within "The Broken Damsel made Whole," a ballad that circulated in the late seventeenth century, which tells of a pregnant unmarried woman travelling to London, where a girl can "be made whole again," to find a rich old widower to whom she could become a servant and later marry. ${ }^{62}$ Though Benion becomes pregnant after her marriage to Twisse and the unnamed servant within the ballad before, the lesson in both tales is to beware the sexual motives of young female servants who seek out wealthy older masters. In terms of the inability to be sure of a child's paternity, examples of this type reveal the anxieties that surrounded women and childbirth. Both in the above illustrations and in sections where he is more severe, Gough's attitudes to illegitimacy echo the class hierarchy that underscores the importance of property, male progeny, and inheritance in The History of Myddle. This is true in two ways. Gough first gives discursive weight to legitimate sons, who are then followed by legitimate daughters, and then illegitimate children. For example, when he mentions the issue of Thomas Kinaston of Wallford, Gough writes that he had two legitimate daughters and one illegitimate son; although the descendants of the two daughters are discussed, there is no further discussion of Thomas Kinaston's bastard son. ${ }^{63}$

\footnotetext{
${ }^{60}$ Gough, 190.
}

${ }^{61}$ Gough, 191.

62" And thus then by her flattering Speech, / knowing that she was undone, / By this Man was made whole again, / when she came up to London." "The Blind Eats Many a Flye: Or, the Broken Damsel made Whole" (16721696[?]), EBBA, University of California Santa Barbara, EBBA ID: 33545, accessed 16 February 2016, http://ebba. english.ucsb.edu/ballad/33545/image.

\footnotetext{
${ }^{63}$ Gough, 84-85.
} 
Second, at a conceptual level Gough sees instances of upper-class illegitimacy less as moral offenses and more in terms of how the transgression affected inheritance. In illustration of this point, Gough details the ruin of Thomas Hall, a man who had fathered a bastard son with one Elizabeth Bickley. After the death of his father-in-law, Hall, like the "sifted" prodigal son of ballad fame, "let loose the reins to many disorderly courses, as cocking, raseing, drinking, and lewdness" and "[b]y these ill courses Thomas Hall consumed his estate." ${ }^{64}$ Stephen Formston fathered a bastard child of a daughter of William Chaloner. Formston "was never marryed" and like Hall, "was accompted to live a debauched life among lewd women." 65 As with the deeds of Elizabeth Davies, Gough establishes bastardy as part of a pattern of immoral behavior as but one component of Hall's and Formston's immorality. In contrast, however, Hall's most damning sin was the wasting of his estate.

In these ways, concern over illegitimacy was intricately connected with class, and for the state at least, illegitimacy amongst the poorer classes was the primary concern, connected as it was with economic matters at the parochial level. And although it would generate greater reproach in the nineteenth century, at this time the base-born children of the upper-classes commonly lived out their lives as recognized offspring of their fathers and with little of the shame the upper classes associated with the illegitimate children of the laboring poor. ${ }^{66}$ This reflected the long-held convention that for men, particularly those of high-status, it was considered advantageous to have many children, specifically sons who could act as heirs and "valuable and unthreatening supporters for their legitimate siblings." 67 In contrast, for a woman

\footnotetext{
${ }^{64}$ Gough, 221.

${ }^{65}$ Gough, 225.

${ }^{66}$ Pinchbeck and Hewitt, 221-22.

${ }^{67}$ Karras, 69.
} 
who was single or widowed and struggled in a household without a breadwinner, having many children was an undue burden.

The association of women with the moral sphere meant that when their behavior was in some way dishonorable, as when they tempted men to sin, for instance, women were often judged heavily. Their moral failures and culpability in bearing bastards is one example of such a failure. Gough's writings speak to other offenses, including those of the most malicious sort. First, there is Gough's retelling of the story of the execution of local miscreant and criminal John Owen, during which he admitted to several misdeeds, including the fact that "a lewd and wicked woman" persuaded him to murder his wife, an act that Owens in the end did not go through with. $^{68}$ Gough remarks that it was "a pitty" that the lewd woman was not hanged along with Owen and, alluding to the medieval myth of Pope Joan, writes quoting the Italian poet Giovanni Battista Spagnuoli: "Here hanged the woman, of her sex the lyer, / Who thereby gott the triple crowne; and by her / Hanged the Pontificall adulterer, her squire." ${ }^{69}$ And, as discussed in chapter two, women were involved in several of the murders that Gough details, including the murder of Mr. Onslow by his wife, Elizabeth, that resulted from a pact among three wives to poison their husbands. ${ }^{70}$ In terms of the thrust of this chapter, however, Gough's portrayal of the Beddow family is the best illustration of this general theme, for as discussed in both chapters three and six, Gough famously impugns Humphrey Beddow's wife and mother-in-law for the family's moral failures.

The study of bastardy in Myddle further illustrates that while both parents were seen as the gatekeepers of familial morality and that men were certainly not immune to the stigma

\footnotetext{
${ }^{68}$ Gough, 150.

${ }^{69}$ Gough, 150, 322 nn.19, 20.

${ }^{70}$ Gough, 148-49.
} 
surrounding bastardy, mothers - due to their inescapable physical association with the bearing of a bastard child - bore the brunt of criticism when this reputation of respectability broke down. After all, even if elite men had the most freedom in fathering illegitimate children without great social scorn, poor men still retained a choice in whether to recognize an illegitimate child as their own. Women for the most part lacked this option. ${ }^{71}$

Gendered conventions of blame are evident in Gough's descriptions of several of Myddle's families who seem to have been habitually inclined to illegitimacy. In fact, these families represent Gough's harshest references to bastardy: whereas occasional lapses resulting in illegitimate children - mere blips in an otherwise respectful pedigree - attract little negative comment, the more consistently disreputable families garner the bulk of Gough's ire. In fact, Laslett uses the examples of the families of William Tyler and Margarett Formston from Gough's text to buttress his arguments concerning the existence of a bastardy-prone sub-society in early modern England. ${ }^{72}$

Gough's anecdotes about William Tyler's exploits are salacious and include tales of illegitimacy, bigamy, and incest that follow and mar the history of his family throughout Gough's narrative. Through these episodes in particular Gough conveys that children often inherit the characteristics - good and bad - of their parents. Tyler's misdeeds were legion (and certainly not confined to bastardy). ${ }^{73}$ It is with Tyler, the family patriarch and the apparent cause of the breakdown of Richard and Elinor (Buttry/Butter) Hussey's marriage, that Gough pinpoints the

\footnotetext{
${ }^{71}$ Karras, 98.

${ }^{72}$ Laslett incorrectly places Myddle in Cheshire. Peter Laslett, "The Bastardy Prone Sub-Society" in Bastardy and Its Comparative History, ed. Peter Laslett, Karla Oosterveen, and Richard M. Smith (Cambridge: Harvard University Press, 1980), 231, 235.

${ }^{73}$ After "hee had wasted most of his Estate," Tyler eventually returned to Balderton, where he lived to an old age, died with "hardly estate left sufficient to defray the charges of a meane funerall," and was notorious for stealing his neighbor's sheep, including "a fatt weather [wether]" of Gough's own grandfather. Gough, 179.
} 
beginnings of the family's troubles. The two parted ways after she and Tyler had an affair, and Elinor later moved to Market Drayton, ran an alehouse, and had a bastard daughter named Nell Hussey. ${ }^{74}$ Gough later writes that "when she was growne up and able to doe service," Tyler took in his illegitimate daughter as his housekeeper "and had a bastard by her."75

Tyler had three (apparently legitimate) children: Richard, Anne, and Elizabeth. Richard in contrast to his father, lived in relative good repute, but of his daughter Anne, Gough records that her husband, Richard Cleaton, left her while she was "bigge with child," who, when born, was brought up by Allen Chaloner, a local blacksmith, and his wife, the latter a relation to Anne's father. ${ }^{76}$ Cleaton then:

went into the further part of this County; and below Bridgnorth hee gott another wife, and had severall children by her. At last, Annie Tyler, his first wife, caused him to bee apprehended, and indicted him att an Assizes at Bridgnorth upon the statute of Poligami. Shee proved that shee was marryed to him, but could not prove that hee was married to the other woman, but only that he lived with her, and had children by her. The other woman denied that shee was marryed to him; and thereupon the Judge sayd 'Then thou art a whore.' To which shee answered 'the worse luck mine my lord.' Cleaton was acquitted, and went out of the county with the other woman, and I never heard more of him. ${ }^{77}$

Gough then goes on to describe a long pedigree of immorality, stemming from Tyler and enduring in the misdeeds of his descendants. For instance, Gough subsequently remarks that Elizabeth, Tyler's second legitimate daughter, "was more commendable for her beauty than her chastity, and was the ruin of her family," before quoting the Roman poet Juvenal: "Intoleribilius nihil est quam foemina fluxa [Nothing is more intolerable than a loose woman]." ${ }^{78}$ Elizabeth

\footnotetext{
${ }^{74}$ Gough, 124-25.

${ }^{75}$ Gough, 176.

${ }^{76}$ Gough, 93, 176-80.

${ }^{77}$ Gough, 93.

${ }^{78}$ Gough, 206-7
} 
eventually married William Bickley and had two sons and three daughters. Of Elizabeth and William's children, Gough writes that although Thomas, the eldest son, lived in good repute, William, the second, tended to the vices of his maternal grandfather, while the three daughters "followed the mother's vices. ${ }^{79}$ Susan, the youngest daughter, had a bastard daughter by John Billingsley, the vicar of the nearby parish of Kinnerley. This daughter reportedly became pregnant after attending Billingsley's wife, who herself was with child, marking another female servant of dubious moral character. Not long afterward, Susan returned to Myddle and lived with her mother Elizabeth, but both soon died of fever. Sardonically perhaps, Gough brings a close to the tale by noting that the parish maintained the child ${ }^{80}$ Middle daughter Elizabeth had a male bastard by Thomas Hall of Balderton. The son eventually became disabled and was cured and maintained by the parish. About this, Gough was sufficiently annoyed to twice write of the great cost of the operation Hall's son underwent, which added up to nearly $£ 20 .{ }^{81}$ Mary, the eldest daughter, married George Reve of Fenemere and although Gough has nothing of disrepute to say about Mary herself, observes that her three daughters were "infamous for their lewdness." 82

The relations of Margarett Formston are the second bastardy-prone Myddle family noted by Laslett. Formston, who was married to Myddle cooper William Chaloner and is described by Gough as a "light housewife":

left three daughters, two of which are as impudent whores as any in this country; one of them has two bastards, and shee being run out of the country, they are both maintained by the parish. The other is now (Jan. 20, 1701,) great with a bastard, and at Christmas last was sent by order into Wem parish, where her last service

\footnotetext{
${ }^{79}$ Gough, 207.

${ }^{80}$ Gough, 207.

${ }^{81}$ Gough, 207, 221.

${ }^{82}$ Gough, 208-9.
} 
and settlement was. Shee has fathered itt on Stephen Formston, her uncle's son, and hee is fled. ${ }^{83}$

In spite of the fact that Gough does not record instances of bastardy in connection with the family of local weaver Thomas Davis and his unnamed wife, here he more explicitly associates the immorality of "bad" families with fear over the effect of lower-class fecundity on the parish rates. These individuals wantonly proliferate and swamp local resources, to the harm of more respectable families of the parish:

Of these two persons ... hath proceeded such a numerouse offspring in this parish, that I have heard some reckon up, takeing in wives and husbands, noe less than sixty of them and the greater part of them have beene chargeable to the parish. Many great familyes in this parish have been extinct, but this has gott soe many branches that it is more likely to overspread it. ${ }^{84}$

When writing about individuals from the lower end of Myddle's social hierarchy, Gough tends to see their moral faults in terms of the parish rate, as in his account about the Tyler family. The poor are seen by Gough in terms of their cost - moral and financial - to the parish. This suggests that the financial strains of the parish influenced ideas about class and immorality. As Gough shows, elites could be immoral, but since they represented no real financial threat to the parish, they appear to have been judged predominantly for the wasting of their estates. In other words, the stakes involved in their transgressions were not as high as they were for the poorer members of the community, showing how the poor law system acted upon traditional ideas about morality to tip the scales towards a more negative view of the immoral poor. To be sure, estate wasters failed to be responsible members of the parish community, but they did not represent the same danger to the parish as a poor family with several children whose members were dependent on parish support and whose head was unsuccessful in providing for his family.

\footnotetext{
${ }^{83}$ Gough, 227.

${ }^{84}$ Gough, 243.
} 
Gendered expectations fused with these financial considerations. To utilize a useful parallel from central Europe, the German concept of Hausvätter complements the importance placed upon the role of male property owners in the English parish. Responsible for upholding order, the Hausvätter was depended on to safeguard the community from "drains on the community poor chest, the addition of 'poor householders' into the ranks of property owners and family heads, and social divisiveness," the latter of which often encompassed illegitimacy and other deeds of sexual immorality. ${ }^{85}$ Thus, although the Beddows, Tylers, and Davises most forcefully give voice to Gough's anxieties surrounding immorality and poverty, the principle of settlement as it operated within the poor laws suggested that the most reprehensible offense of poor husbands and fathers was their failure to provide for their families and sustain the basic system of community order. A father was expected to take care of and be responsible for his family, which meant that the idle male householder "caused not only personal damnation but collective suffering" for the other members of his family, as well as the community writ large. ${ }^{86}$ Just like their German counterparts, these unsuccessful householders, with their "lack of capital, laziness, profligacy, or bad judgement," were blamed for shrinking "the tax base while adding more demands on charity." ${ }^{87}$

The "disorderly" poor also subverted the natural order of things. In The History of Myddle, Gough censures Thomas Noneley, who, after the death of his wife, fell to drink and became so indebted that "his poore children were forced to trust to themselves, and worke for theire liveing." 88 As well, Gough notes that when Richard Jukes II, who was much indebted in

\footnotetext{
${ }^{85}$ Hull, 37.

${ }^{86}$ Waddell, 90.

${ }^{87}$ Hull, 37-38.

${ }^{88}$ Gough, 230-31.
} 
life, died impoverished he left behind "many small children." ${ }^{19}$ There is also the the Pickstock family, about whom Gough writes that George Pickstock, the family's progenitor, was an infamous reseller of stolen goods. George's son, John, came to be a servant to Gough's father-inlaw, after he "gott a wench with child and fled away." ${ }^{90}$ When the authorities came after him, he again absconded. Nonetheless, Gough seems a bit ambivalent about John's character, for he notes that "he was an able and active person in husbandry." 11

Although the typical pattern - and cultural trope - was that of unfortunate families abandoned by the male breadwinner, both Samuell Downton and his wife abandoned their children, four of whom were afterwards maintained by Ellesmere parish. The pair reportedly turned to begging in Staffordshire before Downton's wife left him and he afterwards returned to Shropshire to be supported by his son. ${ }^{92}$ That the father had to be maintained by his offspring represented a clear reversal of the moral order, and a world turned upside down.

Conversely, those who instead were hardworking and productive, in the face of great hardship and despite having a "great charge of children" to maintain, were to be commended. Plainly, Gough thinks the better of the poor weaver, William Parkes, who had eleven children, "yet neither he nor any of his children were chargeable to the parish." ${ }^{93}$ Industriousness therefore blunted the stigma of poverty.

Examination of Myddle's other parish records adds weight to Laslett's observations about bastardy both within the discrete, local world of Myddle as well as the larger context. Although only a scant seventeen bastardy bonds and two bastardy examinations survive from Myddle's

\footnotetext{
${ }^{89}$ Gough, 100 .

${ }^{90}$ Gough, 144.

${ }^{91}$ Gough, 144 .

${ }^{92}$ Gough, 198.

${ }^{93}$ Gough, 132 .
} 
parish chest, they too show a proclivity towards bastardy among certain individuals and surnames. ${ }^{94}$ Again, bastardy examinations were created when local officials interviewed an unwed mother in order to find out the purported father's identity, while bastardy bonds embodied the parish's attempt to assign the child's father the responsibility for his or her financial support. This meant that a bastardy bond characterized a parish's attempt to insure itself against any costs associated with supporting an illegitimate child.

The periodization of these documents in Myddle is somewhat intermittent, but comprises the years 1710 to 1778 , with the heaviest documentation occurring in the 1730 s through the 1770s. A fair amount of geographic spread is represented in these documents across Shropshire, with reputed fathers residing in the nearby town of Shrewsbury and parishes such as Hodnet, Loppington, Baschurch, Preston Gubbals, Prees, Ellesmere, Wem, and High Hatton, and Wrenbury in the neighboring county of Cheshire, in addition to Myddle itself. The information contained within them is sparse, but the details that are provided reveal a few colorful details, such as the case of a servant fathering an illegitimate child within his master's household. John Chaloner, servant to Richard Chester, was the reputed father of Chester's daughter Susanna's bastard daughter Dinah, born in about 1709 in Peplow, within the parish of Hodnet. ${ }^{95}$ Though little information is revealed about Chaloner's relationship with his master's daughter, it brings up two important realities about sexual relationships of the period as seen in the Hodson testimony above: first, many men's and women's first sexual experiences were either with household servants or occurred while in service themselves, and second, these were unequal

\footnotetext{
${ }^{94}$ While this document group is classified as comprising bastardy bonds, two stray bastardy examinations are intermixed. Bastardy Bonds, 1710-1778, P201/L/6 (Shropshire Archives, Shrewsbury).

${ }^{95}$ Bastardy Bonds, 1710-1778, P201/L/6 (Shropshire Archives, Shrewsbury).
} 
relationships in which men held disproportionate power, influence, and economic control and experienced far less shame than their female partners. ${ }^{96}$

In all, the extant documentation encompasses eighteen couples, or thirty-six individuals, and represent twenty-six surnames: Beard, Bickley, Billis, Birch, Broughall, Chester, Chaloner, Corbett, Darlington, Davies, Ellis, Every, Garmson/Garmston, Hanmer, Heath, Higginson, Holden/Holding, Holmes, Humphrison, Judson, Loten/Loton, Pain/Payne, Preston, Ralphs, Roberts, and Rogers. ${ }^{97}$ What is interesting is that these incidents, at least in cases where it is possible to infer parochial social standing, seem to span from all the way from the upper-class Corbett family to local craftsmen families like the Chaloner and Davies families. Moreover, a few individuals at least appear to have been repeat offenders. Elizabeth Payne gave birth to a bastard daughter named Dinah, whose reputed father was Caleb Ralphs of Ellesmere, in Myddle in 1736, and then bore a bastard son named Richard to Richard Humphrison in Myddle in $1738 .^{98}$

The Garmson/Garmston family was involved in three illegitimate births: those of Elizabeth Bickley to laborer Robert Garmston in 1739 and Jane Ellis to Thomas Garmson in 1754 and again in $1757 .{ }^{99}$ That there is a family connection between Robert and Thomas Garmson appears likely given that the former appears in the bond for the birth of Jane Ellis's first illegitimate child. In fact, in this case the reputed father is not explicitly identified, so it is quite

\footnotetext{
${ }^{96}$ Crawford and Gowing, 142; Karras, 110-11.

${ }^{97}$ Though seventeen bastardy bonds and two bastardy examinations survive (totaling nineteen documents), one examination-bond pair, which dates to 1774-1775, refers to the same couple, Anne Broughall and Thomas Corbett. Bastardy Bonds, 1710-1778, P201/L/6 (Shropshire Archives, Shrewsbury).

${ }^{98}$ Bastardy Bonds, 1710-1778, P201/L/6 (Shropshire Archives, Shrewsbury); Registers of Myddle, 188, 191.

${ }^{99}$ Only the births of Jane Ellis's two illegitimate can be located with any certainty in the parish register; unfortunately, but typical of the time, in neither instance is the father's identity given. Bastardy Bonds, 1710-1778, P201/L/6 (Shropshire Archives, Shrewsbury); Registers of Myddle, 213, 218.
} 
possible that Robert, and not Thomas, fathered Ellis's child, a daughter named Anne. ${ }^{100}$

However, in the case of the second birth, Thomas is explicitly identified in the bond. Reflecting common naming customs for bastard sons during the period, the child was a son named Thomas, the same given name as his reputed father. As well, a Jane Ellis is recorded as having given birth to a bastard son named Richard to William Hanmer in the parish in 1774 . Though not impossible, the long gap between this birth and that of Thomas in 1757 renders it questionable as to whether this in fact reflects a third illegitimate child for the same Jane Ellis. ${ }^{101}$

Perhaps giving some picture as to the difficult and unstable lives of unmarried mothers, the name Jane Ellis frequently appears in Myddle's vestry minutes. In 1750, one Jane Ellis is on the list of those who had received charity on St. Thomas's Day, receiving £1 6s. On 6 March 1760, Myddle's parish vestry allowed one Jane Ellis 6s weekly and the same amount on 31 May 1769 and in May 1774. Entries from 10 June 1776 and June 1779 indicate that this had been reduced to 1s per week. Ellis was also frequently given other types of assistance from the parish: on 9 June 1764 she was given 5s to buy coal, in May 1774 she was again given money (1s) to buy coal, and on 10 June 1776 she appears on the list of those to be given coals.. ${ }^{102}$

Finally, a Mary Davies is recorded as having given birth to an illegitimate child to Thomas Davies, Jr. in 1772. Either another or the same Mary Davies gave birth to an illegitimate daughter named Mary to John Billis in $1775 .{ }^{103}$ Illustrative of Laslett's sparrow

\footnotetext{
${ }^{100}$ Intriguingly, a Thomas Garmston, son of Robert and Anne Garmston, was christened 9 May 1731. Registers of Myddle, 177.

${ }^{101}$ Bastardy Bonds, 1710-1778, P201/L/6 (Shropshire Archives, Shrewsbury); Registers of Myddle, 249.

${ }^{102}$ Myddle Parish (Shropshire), Vestry Minutes, Poor Allowances, 1747-1756, 1757-1764, 1764-1779, P201, Fiches 176-178 (Shropshire Archives, Shrewsbury).

${ }^{103}$ This is made more complicated by the fact that the 1772 birth cannot be located in the parish register. The second one, however, can. Bastardy Bonds, 1710-1778, P201/L/6 (Shropshire Archives, Shrewsbury); Registers of Myddle, 250.
} 
metaphor, the commonness of both the given name of Mary and surname of Davies and lack of corroborating details make it impossible to determine whether this was the same individual.

Myddle's bastardy bonds were gendered in such a way that men were associated with the financial implications of bastardy. Most obviously, this included outlining the reputed father's financial culpability, but was also emphasized in the naming of parish churchwardens and overseers who, as male representatives of the parish, were to receive monies to help support the child. Indeed, it was these conventions themselves that helped create some of the ambiguity surrounding the poor mothers of illegitimate children.

\section{Conclusions: The Dangers of Illegitimacy}

The documents from Myddle dealing with illegitimacy are pertinent to the relevant historiography in a few ways. They support Laslett's postulation of a bastardy prone sub-society. They elaborate on how illegitimacy permeated class, and was in some sense a universalized phenomenon, but was judged differently according to one's social station. In short, disorderly upper-class and poor individuals were held to different standards. Men and women were as well, with the documents authenticating the various ways that sexual immorality was gendered. But, in confirming these known truths about illegitimacy, Myddle's records also particularly evidence illegitimacy's key place in constructing a multifaceted web of disrepute. Second, for the poor the existence of illegitimate children was an important arbiter of belonging. Therefore, the evidence here illustrates the sharp impact illegitimacy placed on belonging for some residents of the community.

Due to the poor laws, anxieties about illegitimacy interwove themselves with concerns over poverty, itinerancy, and the parish rate. Despite the fact that illegitimacy was never a large problem in Myddle, as far as Gough was concerned it generated a reasonable amount of concern. 
This was because bastardy had the potential to act as a drain on parish rates. It was also a nexus point at which settlement was interrogated perhaps most strongly, exemplified by frantic attempts to remove unwed pregnant women from the parish and assign financial responsibility for the child with the reputed father.

These worries also reflected a moral system in which men were generally held financially culpable, whilst women were accountable in a more conceptual and less corporeal ethical sense, for wantonly sullying a family's reputation. While the mothers and fathers of illegitimate children both failed to conform to normative ideas about family, this failure manifested itself in different ways. Even though both sexes were guilty of moral transgressions, the patriarchal system they inhabited placed fatherhood as one "as one of the pillars of order in early modern England and a central component of male authority" and valued a father's ability to properly take care of his dependents. ${ }^{104}$ This was something that the fathers of illegitimate children often failed to do and sometimes had to be compelled by law to achieve.

Though not exclusively so, women, on the other hand, were more likely to experience moral punishment through incarceration, public shaming, and cruel treatment by parish officials, as women's unequivocal physical connection to bastardy made it such that they bore most of the blame for the offense. ${ }^{105}$ As "A Lamentable Ballad of the Lady's Fall," a traditional song popular throughout the seventeenth century that sings of the titular character's moral failures as an unwed mother, warns: "Take heed ye dainty damsels all, Of flattering words beware; / And of the

\footnotetext{
${ }^{104}$ Shephard, 46-47, 63.

${ }^{105}$ For instance, there are examples of pregnant unmarried women being bribed to deliver their children elsewhere and even abducted and abandoned in a different parish. Anthony Brundage, The English Poor Laws, 1700-1930 (New York: Palgrave, 2002), 15.
} 
honour of your names / Have you especial care." ${ }^{106}$ It is noteworthy that although Gough traces the downfall of the Tyler family with William Tyler, the male head of the family, he outlines the family's immorality primarily through the female line of descent.

These gendered attitudes existed on a spectrum, however, and were clearly affected by class. For example, upper-class men were more so criticized for the deterioration of their property than for their idleness and deficiency as breadwinners, as were poorer men. These qualifications aside, men were associated with the more concrete matters of money and property and women with the more intangible principles associated with morals, family, and home.

Even if expressed divergently, what was common to both men and women was the extent to which sexual morality existed as one element within a complicated system of respectability. As Gough makes clear when writing about many of the men and women who habitually sired and gave birth to illegitimate children, bastardy often was not their only crime. It was simply one part of a complex of immorality that included licentiousness in other aspects of life. Bastardy was merely the manifestation of the sexual component of a more general and pervasive moral corruption, and seen this way, such men and women were regarded as hopeless cases. But although their mothers and fathers were in many cases regarded as lost causes, poor children legitimate and illegitimate alike - presented a different matter for parish officials.

106"A Lamentable Ballad of the Lady's Fall" (1720[?]), British Library, Roxburghe 3.570-571, EBBA, University of California Santa Barbara, EBBA ID: 31270, accessed 16 February 2016, http://ebba.english.ucsb.edu/ ballad/31270/image. 
CHA P T E R 6: "A T W I G G E W I L L B E T T B EN D W HE N I T IS GREENE": PAUPER A P PRENTICESHIP IN M Y D LE

\section{Introduction}

Myddle's apprenticeship records indicate that children formed an exception to the harsher attitudes to the adult poor examined in other chapters. Poor children, unlike adult paupers, were seemingly considered capable of redemption. For this reason, parish officials sincerely seemed concerned to give them the best chance to escape poverty. However, there are two chief qualifications to this set of circumstances, limitations which formed important boundaries to Myddle's moral economy. First was the influence of the charity established by William Gough, uncle of The History of Myddle author Richard Gough. Gough's apprenticeship charity was the source for setting out many of Myddle's pauper apprentices, which led to the relatively compassionate treatment of local pauper children. This differed from the typical pattern of binding out of pauper apprentices under the poor laws, where children were often apprenticed into low-status trades and the main source of funding was the parish poor rate. Charity apprentices, on the other hand, were considered of the deserving poor and, when local conditions were conducive to such management, were, as in the example of Myddle, treated more like private apprentices. While slightly atypical, parish apprenticeship charities were attested in other parishes throughout England during this period, and were often set up as a way of apprenticing local poor children. This meant, however, that the relatively benevolent treatment of Myddle's pauper apprentices probably stemmed from the parish's ability to utilize charitable funds, and the system would have arguably worked in a different manner had this not been the case. Second, while Myddle's charity apprenticeships conformed to the above established patterns, this applied only to boys, with gender forming the second key dynamic within Myddle's moral economy. In contrast to their male counterparts, female apprentices from Myddle had more in common with 
the pauper apprenticeship model, demonstrating the contours of a gendered system of poor law administration.

These findings thus question past interpretations of the community of Myddle as a society marked by stability and permanency, attributes that were clearly experienced by only a segment of the population. ${ }^{1}$ This research also illustrates the difficulty in constructing any kind of unified narrative about the day-to-day operation of the poor laws at the local level, or about the poor themselves as an undifferentiated group. ${ }^{2}$ As does that presented in other chapters, the evidence from Myddle's apprenticeship records suggests that one's experience of poverty was highly contingent.

\section{Apprenticeship and the Poor Laws}

Apprenticeship was a form of training used in wider society as a way to instruct young people. At the same time, parish officials used it to relieve poverty as part of the poor laws. Due to this complex environment, before exploring evidence from Myddle it is necessary to discuss the history of apprenticeship and outline the various types that existed in early modern England. This includes charting key steps in the governmental regulation of apprenticeship, especially in terms of the poor laws. Moreover, the differences between private, charity, and pauper apprenticeship were such that while apprenticeship was a common experience, it was moderated by factors such as class and gender. As well, changing attitudes to the poor meant that pauper apprenticeship was viewed as a way to teach poor children to become productive members of society. All these conditions lead to interesting questions about the nature and ramifications of

\footnotetext{
${ }^{1}$ This is the view put forward in David G. Hey's An English Rural Community: Myddle under the Tudors and Stuarts (Leicester: Leicester University Press, 1974).

${ }^{2}$ This approach takes a cue from Levene, who writes that "apprentices were not a lumpen mass, and their experiences of service were tied to their differences in background and expectation." Alysa Levene, "'Honesty, Sobriety and Diligence': Master-Apprentice Relations in Eighteenth- and Nineteenth-Century England" Social History 33, no. 2 (2008): 184.
} 
pauper apprenticeship. An important consideration is whether pauper apprenticeship was primarily a way for the parish to get rid of local undesirables, or ultimately served a kinder, paternalistic purpose in removing a child from poverty. Even more important were the ways in which pauper apprenticeship affected the child and his or her family.

Although apprenticeship differed in character according to various factors, including class, it nonetheless served as a surprisingly common experience among young people in English society and helped prepare them for adulthood. During the medieval and early modern periods, apprenticeship operated as a way of training English youth drawn from nearly all social classes. ${ }^{3}$ As well, it is probable that during the late seventeenth and early eighteenth centuries "domestic employment probably reached its peak" with "a large proportion - probably the majority - of the hired labour force" being made up of young apprentices and adult live-in servants. ${ }^{4}$ Since it was a shared occurrence that cut across boundaries, there were similar purposes behind each method of binding out young persons within the community, whether the agreement was privately contracted or arranged by parish overseers or representatives of a charitable institution. In this sense, the various forms of early modern English apprenticeship existed along a continuum, with all of them at times sharing the same features.

Still, while apprenticeship transcended an individual's origins and social background, it also reflected them. In a more vertical sense, and with regard to the growing centralization of Tudor government, apprenticeship also functioned as a way for the government to regulate the labor market and control vagrancy. Moreover, the sixteenth century was a period marked by

\footnotetext{
${ }^{3}$ Deborah Simonton, "Apprenticeship: Training and Gender in Early Eighteenth-Century England," in Markets and Manufacture in Early Industrial Europe, ed. Maxine Berg (New York: Routledge, Chapman and Hall, 1991), 227.

${ }^{4}$ Brodie Waddell, God, Duty and Community in English Economic Life, 1660-1720 (Rochester, New York: The Boydell Press, 2012), 85.
} 
rapid population growth coupled with widespread unemployment, bad harvests, and inflation.

During the reign of Elizabeth I, the government enacted the Statute of Artificers in 1563 in response to the above troubles. Although it was not the first law to do so and there were recognizable post-plague medieval antecedents, the statute represented a comprehensive effort to control the early modern labor market and supplement the power of the guilds. It achieved both aims through its constraints upon worker mobility, establishment of local wage levels, and regulation of apprenticeship. ${ }^{5}$ More specifically, the Statute of Artificers outlined eligibility for those who wished to employ apprentices based on trade, income, and residence. It also delineated the number of journeymen linked to an employer and made a seven-year term for all apprentices mandatory. The restrictions did not apply either everywhere or to all occupations. Even so, the statute did institute universal property qualifications for parents who wished to apprentice their children and set the maximum proportion of apprentices to journeyman in certain trades, such as those related to textile production, cordwaining, and tailoring. ${ }^{6}$

However, the Statute of Artificers applied to apprenticeships arranged privately, or between a child's parental guardian and an employer; it did not apply to pauper or charity apprenticeships. Instead, it was the implementation of pauper apprenticeship as part of the poor laws that complicated the traditional picture of apprenticeship. The passage of the sixteenthcentury poor laws allowed parish officials to bind out pauper children as a way of dealing with poverty at the local level, and charities of various kinds also apprenticed disadvantaged youth for

\footnotetext{
${ }^{5}$ The principal forerunner from the Middle Ages was the 1349 Statute of Laborers, instituted in response to the Black Death. Donald Woodward, "The Background to the Statute of Artificers: The Genesis of Labour Policy, 1558-63," The Economic History Review, n.s., 33, no. 1 (February 1980): 32; Simonton, 228-29.

${ }^{6}$ London and Norwich were exempt from property qualifications, for example, and many historians, including Woodward, have interpreted the resulting statute as revealing the limits of the central government's authority, in that corporate towns were in the end able to wrangle several concessions out of the act. Margaret Gay Davies, The Enforcement of English Apprenticeship: A Study in Applied Mercantilism, 1563-1642 (Cambridge: Harvard University Press, 1956), 1-2; Woodward, 42.
} 
the same purpose. The establishment of pauper apprenticeship, which slightly preceded the Statute of Artificers, dated back to the poor law of 1536. This particular law had given parish officials the power to bind out orphans between the ages of five and fourteen, and later poor laws enhanced these powers to include the apprenticing of all poor children within a parish, as well as the children of any parents parish officials deemed "overburdened" and thus unable to give their offspring proper maintenance and support. ${ }^{7}$ After the Tudor period, pauper apprenticeship became even more interconnected with the poor laws when a subsequent act formally linked apprenticeship with the concept of settlement, arguably the most characteristic feature of seventeenth- and eighteenth-century poor law administration and examined in chapters three and four.

Also during this time, the poor for various reasons came to be perceived as a threat to social order, and the apprenticing of poor children served as a way to break the cycle of poverty by instilling them with the proper cultural values, one of the most important aspects of pauper apprenticeship. Despite expanding government regulation combined with widespread social concerns concerning the poor themselves, the local context nonetheless remained important, and the financial concerns of the parish were also a key factor in shaping pauper apprenticeship, a many-sided and often controversial part of the poor law system.

Therefore, although apprenticeship was experienced by a wide swathe of the general population, the various types of apprenticeship were also distinct, ultimately stemming from the medieval "guild model" but differing from it in both aims and significance. ${ }^{8}$ For instance, private apprenticeship involved a premium paid to a master by a child's guardian in exchange for service, usually a seven-year term. The key feature of this type of apprenticeship was that the

\footnotetext{
${ }^{7}$ Simonton, 229.

${ }^{8}$ Simonton, 229.
} 
agreement was contracted privately - between individuals - and without the oversight of the parish or a charitable institution.

As well, when compared to charity or pauper apprenticeship, the trades to which private apprentices were bound out generally tended to be of a higher socioeconomic status.

Correspondingly, the premiums paid were usually also of a larger amount. A majority of private apprentices were involved in trades classed as "secondary manufacture," for example, the skilled vocation of cloth finishing versus the "primary manufacture" occupation of weaving, a trade to which many pauper children were apprenticed. ${ }^{9}$ There are examples of private apprenticing into lower-status trades, but those who could afford to contract such agreements usually attempted to secure the best position possible for their children's futures. Generally, private apprentices came from families who had enough resources to apprentice their children independently without institutional involvement (apart from the guild system itself).

Local apprenticeship charities, such as the one that existed in Myddle during the period under consideration, due to their frequent parochial connections, had their roots in the Elizabethan poor laws, when the parish became the key administrative unit of poor relief. Although charities meant to relieve poverty had a much longer history, apprenticeship charities of this type were a uniquely post-Reformation phenomenon. Though some of the features of private apprenticeships were true of charity apprenticeships, the main differences were that the agreement was made between a charitable institution, which was responsible for paying the premium instead of the child's parents or guardian, and the humbler nature of both the monetary amount and the trade involved. ${ }^{10}$ Although they might occasionally make it into the more

\footnotetext{
${ }^{9}$ That is, of course, in addition to husbandry, another example of a "primary" state of production. Simonton, 243.

${ }^{10}$ Simonton, 229.
} 
esteemed and affluent trades, charity apprentices tended to be bound into the middling craft occupations. Yet, apprenticeships arranged through charitable sources had a degree of fluidity and functioned as a sort of middle ground between both private and parish arrangements, meaning that charity apprenticeship could take after either form, depending on locality, period, resources, and a variety of other factors. ${ }^{11}$

Overall, the main distinction between a charity and parish apprentice appears to have been one of degree. The charity apprentice was a child deemed "deserving," in that he or she was considered needy in some sense of the word, but ultimately worthy and promising. ${ }^{12}$ In other words, the recipient of a charitable apprenticeship was estimated to be able, given the opportunity, to become a fully-contributing member of English society. This is not to say, however, that there was no degree of connection between charitable and parochial apprenticeships. Again, in Myddle as well as in several other localities, there are instances of individuals with a history in parish administration endowing local charities with the intent of apprenticing local poor children, a phenomena that shows that there was sometimes a good deal of overlap between the different apprenticeship forms. ${ }^{13}$

Still, pauper apprentices were bound out by parish officials with the primary aim of easing local poor rates. Although much evidence indicates that parish officials were genuinely concerned over finding suitable arrangements for the sons and daughters of local paupers, their

\footnotetext{
${ }^{11}$ Simonton, 229.

${ }^{12}$ In fact, strictly speaking a charity apprentice was not even always a pauper. Simonton, 229, 241.

${ }^{13}$ W. E. Tate for instance cites Eccleshall in Staffordshire, Hooton Pagnell and Hull in Yorkshire, and Hindle mentions Myddle as well as the Oxfordshire parish of Henley, Prescott in Lancashire, Low and High Ham in Somerset, Denham in Suffolk, and Kingston-upon-Thames in Surrey as recipients of such endowments. W. E. Tate, The Parish Chest: A Study of the Records of Parochial Administration in England, 3rd ed. (New York: Cambridge University Press, 1969), 117-18; Steve Hindle, On the Parish?: The Micro-Politics of Poor Relief in Rural England, c.1550-1750 (New York: Oxford University Press, 2004), 204-5. See also Hindle's earlier published article, which utilizes much of the same material: "Waste' Children?: Pauper Apprenticeship under the Elizabethan Poor Laws, c. 1598-1697," in Women, Work, and Wages in England, 1600-1850, ed. Penelope Lane, Neil Raven, and K. D. M. Snell (Rochester, New York: The Boydell Press, 2004), 15-46.
} 
consideration nonetheless appears to have been motivated at its root by financial interests. ${ }^{14}$ In consequence, pauper apprenticeships being linked to settlement and the poor rates, it was often the case that pauper children were apprenticed outside their home parishes. ${ }^{15}$ The parish apprentice's premium, typically a lower amount than a private apprentice's, was paid from parish funds. The trade involved was usually of the middling and poorer sort: cordwaining, weaving, or husbandry for boys, and most commonly housewifery for girls. ${ }^{16}$ Indeed, pauper apprentices were customarily apprenticed to husbandry or housewifery, which were in essence not trades at all. ${ }^{17}$ In her study of apprenticeship in eighteenth-century Essex and Staffordshire, Deborah Simonton finds that her data clearly indicate that "some trades were considered appropriate for 'real' apprentices and others for paupers," and the trades that tended to draw pauper apprentices had only small numbers of private apprentices. ${ }^{18}$ In turn, cordwaining and tailoring, which were popular trades for private apprentices, had only small numbers of paupers, who in general tended to be apprenticed in high numbers within agriculture.

Age and length of term are other discernable differences between private and pauper apprenticeships. Whereas private apprenticeships tended to last from the ages of fourteen to twenty-one, resulting in the customary seven-year term, pauper apprenticeships were inclined to both commence earlier and last longer, frequently beginning as early as the ages of seven

\footnotetext{
${ }^{14}$ K. D. M. Snell, Annals of the Labouring Poor: Social Change and Agrarian England, 1660-1900 (New York: Cambridge University Press, 1987), 284-85.

${ }^{15}$ Alannah Tomkins, The Experience of Poverty, 1723-82: Parish, Charity and Credit (Manchester: Manchester University Press, 2006), 188.

${ }^{16}$ It must be conceded, however, that this is a generalization, and there was of course much regional variation. For example, Hindle notes that cordwaining, not husbandry, was the most common trade to which pauper children were apprenticed in Cambridgeshire, and in early seventeenth-century Worth, Sussex the motley lot of two blacksmiths, two ironworkers, one tanner, one warrender, one thatcher, one mason, and one silkweaver all took on parish apprentices. Snell, Annals, 278, 287; Simonton, 232, 240-41; Hindle, On the Parish, 215.

${ }^{17}$ Patricia Crawford, Parents of Poor Children in England, 1580-1800 (New York: Oxford University Press, 2010), 213.

${ }^{18}$ Simonton, 241.
} 
through nine. ${ }^{19}$ The benefits associated with the apprenticing of pauper children at a young age is given voice in the well-known period booklet, An Ease for Overseers of the Poore, published in Cambridge in 1601. In it, the anonymous author declares that because "the poor are by nature much inclined to ease and idleness," it was best to set them out at a young age, for:

as a twigge will best bend when it is greene, so children are fittest to be bound when they are young, otherwise by reason of their idle and base education, they will hardly hold service: but as they have wavering and straying mindes, so they will have wandering and unstaied bodies, which will sooner be disposed to vagrancie then activitie, to idleness then $[$ sic $]$ to worke. ${ }^{20}$

In the seventeenth century, as now, the poor were seen as dangerous due to their numbers and perceived propensity to reproduce, with the author of An Ease for Overseers of the Poor writing of them as a swarming "multitude" and bemoaning:

the poorer sort of men are straight inclined to marrie without any respect how to live: hereof it is that the world growes so populous and poore: for commonly the poore do most of all multiply children ... ${ }^{21}$

In this period, poor children were envisaged in connection with their general laziness and disrespect for the values of decent society, behaviors that were considered "inherited traits." 22 To this end, pauper apprenticeship was meant to school poor children in the proper values of labor and thrift and in this way served as a foil to begging, an activity which contemporary

\footnotetext{
${ }^{19}$ Snell, Annals, 233, 287; Simonton, 239; Hindle, On the Parish, 214.

${ }^{20}$ Ivy Pinchbeck and Margaret Hewitt point out that poor law legislation of this period was frequently quite vague and left much interpretation up to local justices of the peace and parish officials. In fact, the result of this ambiguity, they note, was that Tudor legislation was effectively instituted "by amateurs" instead of any kind of modern state bureaucracy of the modern day. They are not alone in this assessment: Hindle argues much the same. Tracts like An Ease for Overseers of the Poore were another effect, for documents such as this were meant to assist officials in properly and efficiently executing the new system of relief. An Ease for Overseers of the Poore Abstracted from the Statutes (Cambridge, 1601), 27, Early English Books Online (EEBO), accessed 3 March 2014, http://gateway.pro quest.com/ openurl?ctx_ver=Z39.88-2003\&res_id=xri:eebo\&rft_id=xri:eebo:citation:99849139; Ivy Pinchbeck and Margaret Hewitt, Children in English Society, vol. 1, From Tudor Times to the Eighteenth Century (Toronto: University of Toronto Press, 1969), 139; Hindle, On the Parish, 195-203.

${ }^{21}$ An Ease for Overseers of the Poor, 17, 26.

${ }^{22}$ Hindle, On the Parish, 209.
} 
Puritan theologian William Perkins notes merely "set up a school of idleness" should a parish insufficiently provide for its poor. ${ }^{23}$ Echoing this sentiment is Matthew Hale's A Discourse Touching Provision for the Poor, published in 1683:

And which is yet worse, Poor Families which daily multiply in the Kingdom for want of a due order for their Imployment in an honest course of life whereby they may gain subsistance for them and their Children do unavoidably bring up their Children either in a Trade of Begging or Stealing, or such other Idle course, which again they propagate over to their Children, and so there is a successive multiplication of hurtful or least unprofitable People, neither capable of Discipline nor beneficial Imployment. ${ }^{24}$

Thus, the contemporary perception surrounding the lack of an innate work ethic among the poor, of which the above passages are but a few examples, reflects another important characteristic of pauper apprenticeships: that the inculcation of cultural values, such as the importance of labor, thrift, and prudence, appears to have been as important as occupational training in the skills related to a particular trade. ${ }^{25}$ This was arguably true for all apprenticeships, but particularly important in the coaching of pauper apprentices, for unlike more fortunate children, poor children lacked such training at home. Moreover, the financial support of the pauper apprentice by his or her master, which helped alleviate local parish rates, was much more fundamental in parochially-managed arrangements. In actuality, pauper bonds and indentures routinely spelled out the fact that the child's master or mistress was to support his or her charge in a sufficient enough manner that child would not have to fall back on parish relief.

\footnotetext{
${ }^{23}$ William Perkins, A Warning against the Idolatrie of the Last Times and an Instruction Teaching Religious or Divine Worship (Cambridge, 1601), 252, EEBO, accessed 4 February 2015, http://gateway.proquest. com/openurl?ctx_ver=Z39.88-2003\&res_id=xri:eebo\&rft_id=xri:eebo:citation:99898718; also quoted in Hindle, On the Parish, 195.

${ }^{24}$ Matthew Hale, A Discourse Touching Provision for the Poor (London, 1683), 5-A5, EEBO, accessed 17 February 2014, http://gateway.proquest.com/openurl?ctx_ver=Z39.88-2003\&res_id=xri:eebo\&rft_id=xri:eebo: citation:13115847; also quoted in Hindle, On the Parish, 225.

${ }^{25}$ Hindle, On the Parish, 195.
} 
Within the seventeenth-century parish, orphans, poor children, or any child within a family judged to have an excess of dependents could all be bound as apprentices by officials. ${ }^{26}$ Legislatively speaking, employment in the form of putting the poor - including children - to work as a remedy to poverty had a history in English poor law legislation that dated back to at least the Tudor period. ${ }^{27}$ As far as poor law regulation of apprenticeship itself, however, although the 1662 Act of Settlement had defined the concept of settlement as a guiding principle in determining one's eligibility to receive poor relief in a given parish, it was not until thirty years later, in 1692, that apprenticeship was formally outlined as one of the routes to gaining a settlement. ${ }^{28}$ Importantly, this act meant that apprenticing a child outside parish boundaries had the effect of removing him or her to another parish of settlement.

This led many commentators - as well as subsequent historians - to fault parish officials with employing this directive to rid their parishes of such children, who were considered drains on parish funds. This is a characterization that appears to be fair in some cases and unfair in others, as no one paradigm seems to hold for all places across the entire period. In any case, perhaps the central distinguishing feature of pauper apprenticeship, in contrast to its private counterpart, was the fact that the process was entirely managed by parish officials, sometimes contrary to the wishes of the child's parents, to say nothing of those of the child. ${ }^{29}$

There was in fact a substantial amount of coercion involved in the binding out of pauper apprentices, not only for the parents, who often stood to lose parish support if they failed to

\footnotetext{
${ }^{26}$ Pinchbeck and Hewitt, 237.

${ }^{27}$ Hindle, On the Parish, 171-72.

${ }^{28}$ This particular act was For ... supplying the Defects of the Former Laws for the Settlement of the Poor (3 William \& Mary c. 11). Paul Slack, The English Poor Law, 1531-1782 (New York: Cambridge University Press, 1990), 54.

${ }^{29}$ Alysa Levene, "Parish Apprenticeship and the Old Poor Law in London," The Economic History Review 63, no. 4 (2010): 918.
} 
surrender their children, but also for local employers, who were highly encouraged to take on poor children, sometimes at the risk of fines and even litigation. ${ }^{30}$ Masters were often disinclined to employ pauper children for several reasons. This included reluctance to take on the extra burden and a lack of faith in the work ethic of the impoverished. Parents, at the other end of the paradigm, were understandably hesitant to give their children up for an apprenticeship that could frequently be situated in another parish or even county. Again, because an apprenticeship in the later seventeenth century formally conferred settlement, this opened up another dimension to parental opposition, as an apprenticeship outside the parish also entailed the breakup of a family not only in an emotional sense, but also in legal and physical ones, whereby parents and children were afterwards officially "of," that is, settled in, different places. ${ }^{31}$

This could have important ramifications. Extra children were burdensome financially, but their labor could be quite useful in a poorer household. The labor of children was expected to contribute to the household economy, and especially in poorer households, was often necessary. ${ }^{32}$ What scholars have termed the "'substitution effect"' meant that the loss of even a small child's labor within the household was detrimental. Up to about age eight, children could perform simple tasks such as such as gathering firewood and water, cleaning, and caring for younger siblings. Their removal from the household meant that adults might have to take on these responsibilities, robbing their attention from more complex tasks. The loss of a child aged between nine and twelve from the household economy, who could likely tend livestock, spin, knit, and mend clothing, was felt even more acutely. ${ }^{33}$ Indeed, this was often the very age at

\footnotetext{
${ }^{30}$ Hindle, On the Parish, 192, 207-11, 218-23; K. D. M. Snell, Parish and Belonging: Community, Identity and Welfare in England and Wales, 1700-1950 (New York: Cambridge University Press, 2006), 149, 251.

${ }^{31}$ Hindle, On the Parish, 194-95, 199.

${ }^{32}$ Waddell, 93.

${ }^{33}$ Hindle, On the Parish, 194, 210.
} 
which pauper apprenticeships began, which effectively resulted in a poorer household being deprived of a child whose labor had just entered a more useful - even profitable - stage. The apprenticing of one's child by parish officials also had an immaterial but nonetheless significant stigma, in that it marked a parenting failure: for parents, to have a poor child apprenticed "was by implication to impugn the capacity of its parents to inculcate the habits of diligence and deference upon which labour discipline and social order depended." ${ }^{34}$ It was a case where officials' aims and those of a poor family were often in conflict: parish officials wished to remove the financial burdens of a poor child and inculcate him or her with a new sense of labor discipline; a poor family, in contrast, usually desired just enough parish assistance to enable them to make ends meet yet keep their children at home. ${ }^{35}$

Clearly, there was a good deal of controversy surrounding the apprenticing of local poor children by parish officials on a number of fronts, and the matter was a multifaceted and not infrequently a fractious one. This particular aspect of poor law administration was not only a point at which many sources of early modern authority converged, but also one, in its attempt to remove a child from a family judged defective and place him or her into one considered to be more ideal, that interrogated the very nature of the early modern family itself. ${ }^{36}$ And, vexing and uneven though its implementation often was, pauper apprenticeship gave local officials a good deal of power to be wielded with either a harsh or benevolent hand, whichever they judged each particular case to necessitate.

\footnotetext{
${ }^{34}$ Hindle, On the Parish, 210, 226.

${ }^{35}$ Crawford, 158.

${ }^{36}$ Hindle, On the Parish, 194-95.
} 


\section{Apprenticeship Historiography}

The development of the new social history in the 1960s was important to the study of apprenticeship. In its attempt to de-center the poor law narrative, the new social history distinguished itself from the center-focused, administrative histories of the early twentieth century. The study of the poor law as it related to the local context initially tended to be written by historians such as Peter Laslett and E. A. Wrigley associated with the Cambridge Group for the History of Population and Social Structure. ${ }^{37}$ Such studies, according to Paul Fideler, were inclined to eschew the traditional historical narrative of a Tudor, Stuart, or even Hanoverian England, much less any kind of Eltonian "Tudor Revolution," in favor of examining an early modern England that offered a more parochial, and ultimately fragmented, narrative centered on the study of everyday people. ${ }^{38}$ The examination of both the poor laws and apprenticeship has mirrored these general trends.

Prior to the 1960 s, the towering example of an early administrative history dedicated to the poor laws is the leftward scholarship of Sidney and Beatrice Webb. ${ }^{39}$ The Webbs, whose work was published in the early twentieth century, tend to see early modern poor law legislation as merely a continuation of medieval attempts at controlling vagrancy, the result of which was "the enduring distress of the poor." ${ }^{40}$ Although they examine the role of ideology in shaping the poor laws - something unusual in a strictly administrative history - the Webbs in the end highlight the ultimate breakdown of such reforming impulses by the eighteenth century, due to

\footnotetext{
${ }^{37}$ Paul A. Fideler, "Introduction: Impressions of a Century of Historiography," Albion: A Quarterly Journal Concerned with British Studies 32, no. 3 (Autumn 2000): 385, 387.

${ }^{38}$ Fideler, "Historiography," 387.

${ }^{39}$ Sidney Webb and Beatrice Webb, The Parish and the County, vol. 1, English Local Government (London: Longmans, Green and Company, 1906); idem, English Poor Law History, Part I: The Old Poor Law, vol. 7, English Local Government (London: Longmans, Green and Company, 1927).

${ }^{40}$ Fideler, "Historiography," 384.
} 
pressures connected with industrialization and the Napoleonic Wars, among other factors. ${ }^{41}$ Though they laudably seek to rehabilitate the negative views of an inefficient system badly in need of reform that surrounded the poor laws prior to the enactment of the New Poor Law in 1834, the Webbs nonetheless tend to view the historical narrative as embodying a downward, fatalistic spiral toward the abuses associated with the Industrial Revolution. ${ }^{42}$ Concerning apprenticeship, this means that the Webbs envision eighteenth-century apprenticeship, associated as it was with the factory and thus bound up with industrialization, as representing a fundamental break from the preindustrial variety. ${ }^{43}$

Another example of a pre-1960s work covering apprenticeship is Margaret Gay Davies's The Enforcement of English Apprenticeship: A Study in Applied Mercantilism, 1563-1642. This work, in contrast to the Webbs', reflects a more traditionalist twentieth-century administrative approach. In this work, Davies deals chiefly with pre-1642 apprenticeship law, and sees no real connection between the system of parochial apprenticeship associated with the poor laws and the more conventional system of private apprenticeship. ${ }^{44}$ Nonetheless, Davies notes that apprenticeship was, at least in the Tudor period, used as a means to control vagrancy, to which end pauper apprenticeship was even more explicitly employed. ${ }^{45}$ For example, Davies is conscious that legislation, such as the Statute of Artificers, was enacted to deal with sixteenthcentury fears surrounding "bands of roving vagabonds [who presented] a dangerous threat to the security of life and property," along with "the practical problem of a sufficient supply of docile

\footnotetext{
${ }^{41}$ Ideological influences include the humanist ideas of Thomas More as well as those of several Protestant reformers. Fideler, "Historiography," 384.

${ }^{42}$ J. D. Marshall, The Old Poor Law, 1795-1834 (New York: The MacMillan Press Ltd, 1977), 16.

${ }^{43}$ Alysa Levene, "Parish Apprenticeship," 916, 916 n. 7; Sidney Webb and Beatrice Webb, The Parish and the County; idem, English Poor Law History, Part I: The Old Poor Law.

${ }^{44}$ Davies, 12-13.

${ }^{45}$ Davies, 13.
} 
labor in fields and rural crafts," general anxieties about social unrest, and potential threats to both life and property. ${ }^{46}$

Social historians more explicitly examined such issues, however. In their multivolume 1969 study of childhood in English society, Ivy Pinchbeck and Margaret Hewitt similarly recognize that Tudor poor law legislation was meant to prevent unrest and preserve order but more freely appreciate that the various forms of apprenticeship - whether secured on a private basis or, after the passage of the poor laws, on a parish one - were united in a basic aim: the fortifying of "a national system of technical training for the industrial and labouring classes." ${ }^{47}$ Although pauper apprentices did not fall under the guild system, as did private ones, Pinchbeck and Hewitt see it as a mistake to see the two systems as separate. Instead, they reinforced one another. ${ }^{48}$ As well, they are much more interested in looking at the day-to-day workings of the poor law, and in doing so outline several distinguishing features of the parish-based system, noting for example the impact of seventeenth-century settlement laws. The linking of settlement and apprenticeship - whereby one attained settlement in a parish after having served forty days' apprenticeship there - undoubtedly had the consequence of parish officials utilizing apprenticeship as a way of getting rid of local poor children, who it was feared would be a drain on parish rates. ${ }^{49}$

As discussed, another key difference with pauper, as opposed to private, apprenticeship was that while the most important feature of the latter was that a child learn a specific trade, pauper apprenticeship was meant to remove a poor child from a harmful environment so that he

\footnotetext{
${ }^{46}$ Davies, 3 .

${ }^{47}$ Pinchbeck and Hewitt, 223, 224.

${ }^{48}$ Pinchbeck and Hewitt, 234, 241-42.

${ }^{49}$ Pinchbeck and Hewitt, 243.
} 
or she could be morally reformed. ${ }^{50}$ Exhibiting how outlining cultural attitudes can be vital to appreciating the ways in which the various types of apprenticeship were different from one another, Pinchbeck and Hewitt cite that in the mid-seventeenth century several members of the Sheffield gentry tried to secure exemption from the obligation of employing parish apprentices. This was rejected on the grounds that although pauper apprentices were expected to learn practical skills of some sort, the primary object of setting them out was not to instruct them in a trade; rather, charity and the prevention of them turning idle and vagrant were the true purposes. ${ }^{51}$ However, despite the fact that theirs is meant to be an all-encompassing study of English childhood, Pinchbeck and Hewitt contemplate such issues not in a national or legislative context, as does Davies, but within a local framework, a trend that has largely continued in poor law studies up to the present.

For example, like many social histories of poor law administration, Timothy Wales's is also a local study. Wales looks at the ways in which poverty was experienced by the poor themselves and explores the "economy of makeshifts" utilized by them in order to survive. ${ }^{52}$ Wales writes that up until that point (c. 1984), most studies of the English poor laws had merely "concentrated on the minutiae of administration, to the exclusion of any real social context." ${ }^{53}$ In his examination of poverty in Norfolk, Wales tries to identify at what point in the life-cycle an

\footnotetext{
${ }^{50}$ Pinchbeck and Hewitt, 234.

${ }^{51}$ Pinchbeck and Hewitt, 235.

${ }^{52}$ To use Olwen Hufton's oft-quoted and influential phrase, which is cited by Tim Wales and discussed by Alannah Tomkins and Steven King, who outline the ways in which the French concept differed from the English, the latter coming to mostly refer to any of the short-term strategies used by the settled, laboring poor to make shift. Olwen Hufton, The Poor of Eighteenth-Century France, 1750-1789 (Oxford: Clarendon Press, 1974); Tim Wales, "Poverty, Poor Relief and the Life-Cycle: Some Evidence from Seventeenth-Century Norfolk," in Land, Kinship, and Life-Cycle, ed. Richard M. Smith (New York: Cambridge University Press, 1984), 353; Alannah Tomkins and Steven King, eds. The Poor in England, 1700-1850: An Economy of Makeshifts (Manchester: Manchester University Press, 2003), 1, 11-13; Alannah Tomkins, The Experience of Poverty, 239.

${ }^{53}$ Wales, 352.
} 
individual was most likely to resort to parish relief. He finds that households overburdened with children, widows, orphans, and the aged formed the vulnerable, and also charts the growing importance of parish relief during the course of the seventeenth century. ${ }^{54}$ Wales, through his concentration on the life-cycle, examines age as a factor in susceptibility to falling on parish relief, particularly for widows. ${ }^{55}$ Though his is not a study of apprenticeship as such, Wales also explores the role of family size in increasing the odds of a family sinking into poverty ${ }^{56}$ In this way, pauper apprenticeship is envisaged by Wales "as a means of transferring children from families which could not support them to families which could. ${ }^{57}$

Similarly, K. D. M. Snell, a social and rural historian, examines the quality of life and general declining position of the laboring poor in the eighteenth and nineteenth centuries in England's agricultural south. ${ }^{58}$ Through quantitative analysis, Snell demonstrates that as their bargaining power decreased, the situation of the rural poor in southeast England gradually deteriorated throughout the period into insecure positions of day labor. For men, in-service and apprenticeship declined at the same time as there was a loss of access to land due to enclosure. All of these things, Snell argues, led to the proletarianization of the rural laboring class, those whom industrialization had left behind.

\footnotetext{
${ }^{54}$ Using the methodology of family reconstitution, Samantha Williams, a member of the Cambridge Group, much like Wales calls attention to the three key life-cycle stages when one became exposed poverty and the need to seek relief: childhood; middle age, or the stage when a family had a large number of very young children; and old age. In addition, Williams stressed that it was the "broken family" - through death or abandonment - that was most often the recipient of relief. Samantha Williams, Poverty, Gender and Life-Cycle under the English Poor Law, 1760-1834 (Rochester, New York: The Boydell Press, 2011), 1, 12-13, 102; Wales, 353, 354, 387.

${ }^{55}$ Wales, 360-9.

${ }^{56}$ Wales, 374-75, 378.

${ }^{57}$ Wales, 376.

${ }^{58}$ Snell, Annals.
} 
The work of Wales and Snell in general put forward a fairly dismal picture of the laboring poor of pre-industrial and industrializing England. ${ }^{59}$ More recently, historians such as John Broad and Steve Hindle have expanded the social history approach, complicating the picture of poverty in early modern England. In a slant that typifies the long-standing emphasis on the local and echoes the methodology of Pinchbeck and Hewitt, Broad proposes "a more holistic approach to understanding the Old Poor Law" through the interaction between various sources of local and regional authority, as well as different social groups, all factors that reinforced various experiences of poverty. ${ }^{60}$ In this sense, Broad's emphasis on interaction and negotiation is differentiated from the Cambridge Group's investigation of "long-term trends."61 Hindle similarly considers how the poor laws created a space for the interaction of various sources of authority, and more particularly examines the ways in which pauper apprenticeship created tensions in the community, arguing that "the enforcement of parish apprenticeship was deeply problematic for judges, magistrates, and parish officers; for parents, employers, and ratepayers; and, not least, for the children themselves." ${ }^{62}$ Hindle also perceives that children served as a litmus test for separating out the deserving and undeserving poor "at the very time when that age-old binary distinction was being distorted by the 'discovery' of the labouring poor in the urban censuses of the late sixteenth century." 63

\footnotetext{
${ }^{59}$ In fact, one of the results of the examination of the poor, and by implication pauper apprenticeship, by historians has been the split between the "optimists" and "pessimists." This break is of course connected to the infamous and long-running "standard-of-living" debate concerning the effects of the Industrial Revolution in Britain. Several points should be qualified, however. Snell himself acknowledges that had he looked at data from northern England and not confined his study to southern counties, this might have yielded a much different, and more "optimistic," picture. Additionally, his later work has attempted to transcend the optimist-pessimist gap. Snell, Annals, 2-3; Fideler, "Historiography," 394, 402-3.

${ }^{60}$ John Broad, "Parish Economies of Welfare, 1650-1834," The Historical Journal 42, no. 4 (December 1999): 985.

${ }^{61}$ Broad, 988.

${ }^{62}$ Hindle, On the Parish, 223-24.

${ }^{63}$ Hindle, On the Parish, 224.
} 
In their highlighting of negotiation, cultural historians have tended to hone in on apprenticeship as a source of unease and conflict. For example, Sandra Cavallo notes that this period in a young man's life was one in which he sought a "negotiable family" of sorts in the pulling away from the nuclear household and father and forging new relationships, particularly with his master. ${ }^{64}$ Moreover, even when apprenticing took place within a familial environment, Cavallo's gender analysis and study of the neighborhood and kinship ties of artisans whose trades were dedicated to the care of the body - barbers, jewellers, perfumers, surgeons, tailors, upholsterers, and wigmakers - in early modern Turin, describes the types of tensions that could develop between fathers and sons. ${ }^{65}$ Regarding English apprenticeship patterns, Steven R. Smith maintains that a distinct youth subculture existed among London apprentices and that apprenticeship clearly marked "a transitory period between 'the morality learned by the child, and the ethics to be developed by the adult,"' something noticeably attested to in contemporary ballads, tales, and advice literature. ${ }^{66}$ Using much different sources from administrative historians, Smith looks how the apprentice within the household could sometimes lead to anxiety or conflict. Such tensions owed to the re-homing of a young person into a new household, something which produced "role confusion" regarding the apprentice's integration into the master's domestic hierarchy. ${ }^{67}$ Women within the household seemed to be particularly problematic, and Smith reports that the "frequency of complaints about the domination by

\footnotetext{
${ }^{64}$ Sandra Cavallo, Artisans of the Body in Early Modern Italy: Identities, Families and Masculinities (New York: Manchester University Press, 2010), 186.

${ }^{65}$ For instance, Cavallo described how legal emancipation was an option for a son seeking to discharge traditional obligations to his nuclear family. Cavallo, 202-8.

${ }^{66}$ Steven R. Smith, "The London Apprentices as Seventeenth-Century Adolescents," Past \& Present, 61 (November 1973): 158.

${ }^{67}$ Smith, 160.
} 
women indicates the sexual confusion which is a part of adolescence." ${ }^{68}$ What Smith fails to observe, however, is that these anxieties might not indicate sexual tensions as much as apprehensions resulting from the reversal of traditional gender roles.

Scholars have in recent years more adequately focused on gender as a category of analysis in the study of early modern English apprenticeship. For example, Deborah Simonton explores gender as a factor revitalizing the study of apprenticeship, suggesting that the evidence prevents "any attempt to treat it as a monolithic form of training with a single function." ${ }^{69}$ If Broad and Hindle analyze authority and the negotiation and interaction inherent in power relationships, Simonton does the same by rejecting the master narrative and recognizing the gendered nature of those power relationships. Importantly, Simonton argues that the clear gendered division of trades and undervaluation of female labor evident in indentures from Essex and Staffordshire illustrate the decidedly dissimilar male and female experiences of apprenticeship. $^{70}$

Though not so heavily focused on gender, Alysa Levene takes up many of these same themes in her examination of apprenticeship in the eighteenth and nineteenth centuries. Levene approaches apprenticeship utilizing records from the London Foundling Hospital, contemporary literary sources, and a case-study methodology to illustrate how previous attempts to understand apprenticeship had been inadequate. ${ }^{71}$ Previous studies, according to Levene, had highlighted

\footnotetext{
${ }^{68}$ In fact, this is precisely the point examined by Robert Darnton, also a cultural historian, in the title essay of his well-known work of popular history, The Great Cat Massacre and Other Episodes in French Cultural History ([New York: Vintage Books, 1985]). In any case, Smith sums up the main tensions aptly, writing that the trouble was caused by the fact that young apprentices "were taken from their families at a crucial stage in their development and put into other families of which they were a part, yet always apart; they were in, but not of." Smith, 160.

${ }^{69}$ Simonton, 249.

${ }^{70}$ Simonton, 244.

${ }^{71}$ Levene, "'Honesty, Sobriety and Diligence,"'188.
} 
apprenticeship misbehavior and maltreatment and consequently overlooked "the wide variety of experiences of apprenticeship and how this might change over the course of a relatively long period of service." 72 When a distinction had been made at all, historians up to that point had preferred to look at apprentices using a wealth-poverty distinction. Instead, Levene attempts to take into account the many other factors affecting an apprentice's experiences, including skill, geographical variation, physical impairment or disability, and gender. ${ }^{73}$

Levene's later work deals with apprenticeship in the second half of the eighteenth through the nineteenth centuries, and speaks to another historiographical thread regarding apprenticeship: the enquiry into whether pauper apprenticeship was truly a way for parishes to get rid of excess poor children as well as the ways in which industrialization affected the parish-based system. Here, Levene rejects the "pessimistic" view of pauper apprenticeship and instead argues for continuity. ${ }^{74}$ Her picture therefore differs from the older interpretation of pauper apprenticeship that had characterized factory apprenticeship as marking a departure from the older pauper apprentice-master paradigm, a long-held maxim going all the way back to the Webbs. ${ }^{75}$

The influence of cultural history has often spurred the re-examination of older models of the Industrial Revolution that tended to espouse a central narrative and one-size-fits-all models that painted the effects of industrialization as either overwhelmingly positive or mostly negative. In his study of apprenticeship, for example, Hugh Cunningham questions studies that have seen a

\footnotetext{
${ }^{72}$ Levene, "'Honesty, Sobriety and Diligence,"' 183-84.

${ }^{73}$ While Levene does not explicitly mention gender here, she does employ it as a means of investigating attitudes toward and expectations of apprentices. Levene, "'Honesty, Sobriety and Diligence,"' 184, 190.

${ }^{74}$ Levene advises that although pauper apprenticeship allowed parish officials "to dispose of large numbers of children at one time," and despite the fact that they were helping to create "a flexible and specialized factory labour force," they were, in essence, still "applying old practices to changed labour needs." Levene, "Parish Apprenticeship," 916.

${ }^{75}$ Levene, "Parish Apprenticeship," 916, 916 n. 7; Sidney Webb and Beatrice Webb, The Parish and the County; idem, English Poor Law History, Part I: The Old Poor Law.
} 
high level of child employment throughout the early modern and modern periods. Cunningham points out that it was often the optimists who had an interest in maintaining "that children had always worked." ${ }^{76}$ As for questioning the pessimist hypothesis, Katrina Honeyman disputes that pauper apprenticeship was a means for parish officials to offload poor children, both in the preand post-industrial period, and cites evidence of parishes continuing to look out for young apprentices even after they had been bound out to another locality. ${ }^{77}$ Moreover, Honeyman reiterates the turn that poor law historiography has tended to most recently take when she notes that the system could variously be generous and harsh both from place to place and over time. ${ }^{78}$ Blurring the lines between the positive and negative aspects of industrialization, both of these historians show how all-encompassing paradigms often prove inadequate in outlining the effects of the Industrial Revolution.

Apprenticeship in Myddle speaks to recent historiographical developments that realize apprenticeship as part of an integrated social world, where one type of apprenticeship did not exist mutually exclusive from another. Moreover, apprenticeship in Myddle is revealing of the tensions and divisions within the early modern community, as stressed by Broad and Hindle and seen through the deserving-undeserving model, through the dissimilar treatment of charity and parish apprentices. This is ultimately an enquiry into why certain poor children were seen as deserving of charity and others were not.

More particularly, what Myddle's apprenticeship records demonstrate is that the poor children of the parish were not treated as simple consumers of parish resources, as both the

\footnotetext{
${ }^{76}$ Hugh Cunningham, "The Employment and Unemployment of Children in England, c.1680-1851," Past \& Present 126 (February 1990): 116.

${ }^{77}$ Katrina Honeyman, Child Workers in England, 1780-1820: Parish Apprentices and the Making of the Early Industrial Labour Force (Burlington, Vermont: Ashgate Publishing Company, 2007), 24-26, 36.

${ }^{78}$ Honeyman, 17.
} 
scholarship focused on administrative history and more "pessimistic" historians have argued.

Rather, the evidence here supports the arguments of Simonton as well as Levene and Honeyman, but with the caveat that poor girls marked a noted exception, their treatment appearing to have been even harsher than that recorded by Simonton's general examination of charity apprenticeship. Myddle's parish records show that poor relief was not a monolithic system, nor was poverty a universal experience. This is true even when dealing with pauper apprentices, a group traditionally envisioned as a cohesive classification, and distinct from private apprentices. Myddle's apprenticeship records reveal a complicated narrative that in many ways eschews a unified narrative about the system of parish apprenticeship set up by the poor laws. It explores the various ways in which it could reflect - and provoke - sources of conflict and cultural attitudes at the same time as it acted as a way to stabilize the local community.

\section{Pauper Apprenticeship in Myddle}

The data sample analyzed here comprises 136 indentures and bonds from 1672 to 1800 . This study ends at the point where the social changes associated with industrialization stimulated widespread discussions about the poor laws, debates that permanently altered the landscape of poor law administration in 1834 with the passage of the New Poor Law. For the period under examination, approximately ninety pauper apprenticeship indentures and 46 bonds survive from Myddle. The former group of documents dates from 1673 to the period just before the passage of the New Poor Law in 1834. The latter collection covers the shorter period of 1672 to 1752. This study makes use of both sets of documents, within which there is considerable overlap and refer to the apprenticing of 101 individual children. The average apprenticeship premium amount was just over $£ 5$, an amount that remained relatively steady over time and also seems to 
have been roughly in line with pauper apprenticeship premiums elsewhere. ${ }^{79}$ In terms of periodization, the parish arranged on average slightly less than one (0.8) apprenticeship per year, with the rate remaining relatively stable over the record-keeping period (see Figure 6.1 below). ${ }^{80}$

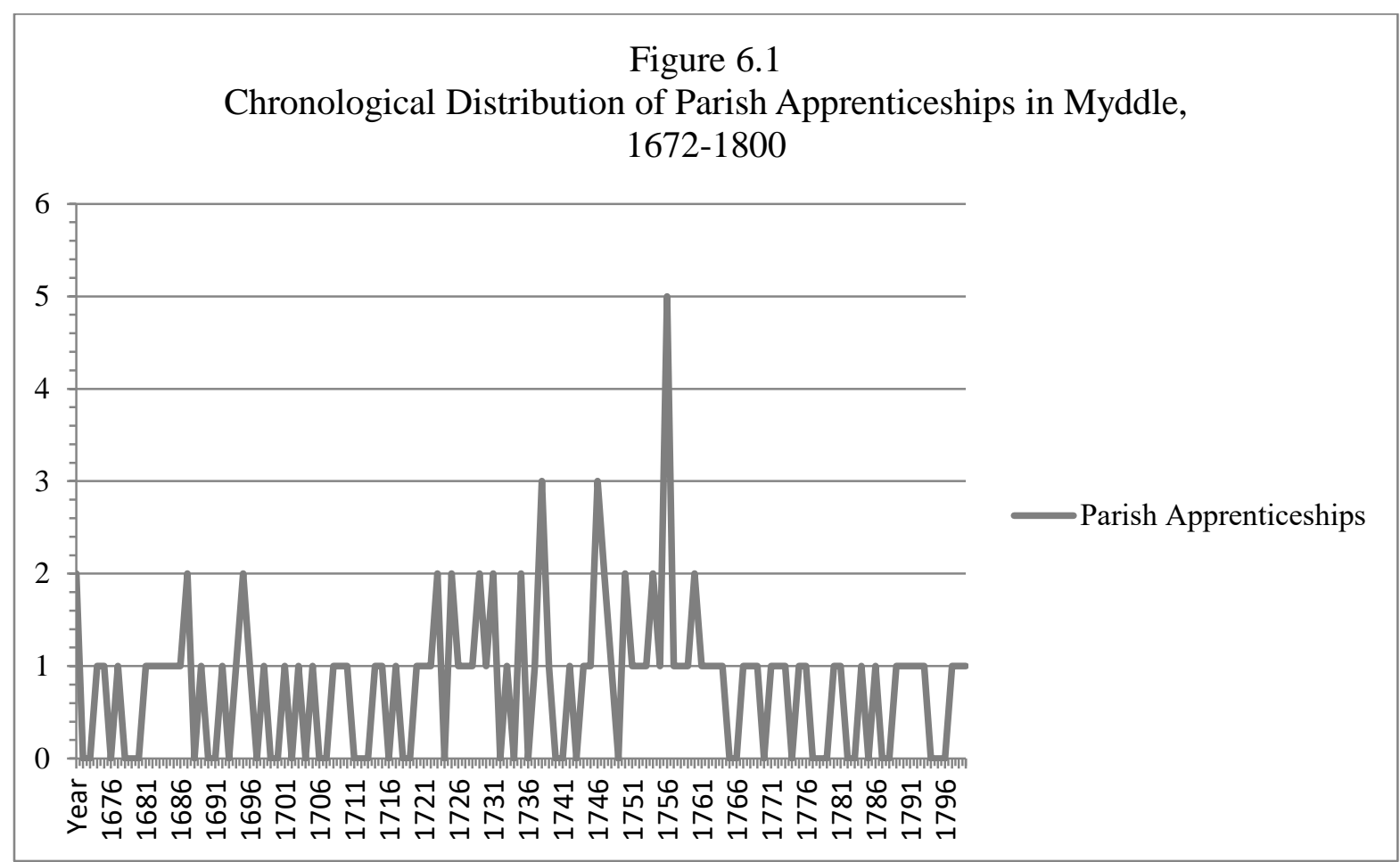

The age of the child at the time of binding is rarely mentioned, with most being simply described as "a poor child of the parish." In total, 84 boys and 17 girls were apprenticed in Myddle between 1672 and 1800. Other features of these documents - what trade a child was apprenticed into and whether he or she was apprenticed to a family member or through the use of charitable funds, any stipulation of extra educational and religious training to be provided to an apprentice, and a reconstruction of the master-to-apprentice sex ratio - all form the basis for

${ }^{79}$ Joan Lane reports of the difficulty in assessing average pauper apprenticeship premiums due to the great variety in local practices and irregular record keeping, but in Southhampton pauper apprenticeship premiums from 1609 to 1708 ranged from $3 \mathrm{~s} 4 \mathrm{~d}$ to $£ 8$, with most being in the range of $£ 1$ to $£ 110$ s, and in Old Swinford, Worcestershire during the late seventeenth and early eighteenth centuries the majority of premiums were over $£ 3$. Joan Lane, Apprenticeship in England, 1600-1914 (London: University College London Press, 1996), 22-23.

${ }^{80}$ Myddle Parish (Shropshire), Apprenticeship Indentures, 1672-1891, P201/L/8 (Shropshire Archives, Shrewsbury); Myddle Parish (Shropshire), Apprenticeship Bonds, 1672-1752, P201/L/9 (Shropshire Archives, Shrewsbury). 
arguing that while William Gough's apprenticeship charity was an important moderating influence, boy and girl apprentices were treated differently in the parish of Myddle.

With regard to evidence, where administrative parish poor law records are extant, indentures and bonds are normally what remain of parochial apprenticeship papers, and since pauper apprenticeship was widespread, its documenting tended to be standardized. ${ }^{81}$ In drawing up a pauper indenture, the usual conditions to be met were the execution of the agreement within the presence of the child, his or her parents or guardians, the child's master, and parish officials, and its approval by two local justices of the peace. ${ }^{82}$ The stipulations contained within the indenture itself were legalized within a second official document, the apprenticeship bond. This generally contained a preamble, written in Latin before 1733 and in English afterwards and similar to that used in bastardy bonds, with the rest of the text allowing for the revoking of the agreement were its conditions not met $^{83}$ :

Noverint universi per presentes, mee Thomam Francis de Parochia de Shrawardine in Com Salop Architectum teneri et firmiter obligari Richardo Mall de Middle in Com Salop in viginti libris bonae et legalis monetae Magnae Brittaniae solvend eidem Richardo Mall aut suo certo Attornat Executor Administrator vel assignatis suis ad quam quidem solutionem bene et fideliter facend Obligo me Heredes Executores et Administratores meos firmiter per presentes sigillo meo sigillat dat decimo octavo die Januarii Anno Regni Domi nostris Georgii Secundi dei Gratia Magnae Brittaniae Franciae et Hibernia Regis fidei Defensor \&c Quarto Anoq Domi 1730/31

[Know all by these presents, that I Thomas Francis of the parish of Shrawardine in the County of Salop Builder am held and firmly bound to Richard Mall of Middle in the County of Salop in twenty pounds of good and legal money of Great Britain to be paid to the same Richard Mall or his certain Attorney Executor 
Administrator or assigns for which payment well and truly made I bind myself my Heirs Executors and Administrators firmly by these presents sealed with my seal dated the eighteenth day of January in the Fourth Year of the Reign of Our Lord George II by the Grace of god King of Great Britain France and Ireland Defender of the faith \&c and in the Year of the Lord 1730/31]

The Condition of this Obligation is such that if the above bounden Thomas France[s] his Heires Executors \& administrators \& every of them do make and shall in all things well \& truly observe performe fullfill accomplish pay \& keep all and singular the Covenants, Grants Articles Clauses Provisoes Payments Conditions \& agreements which on the part and behalf of the said Thomas France[s] his Heires Executors \& administrators are or ought to be observed performed full[fill]ed accomplished paid \& kept comprised or mentioned in Certain Indentures bearing Date with the above written Obligation made or mentioned to be made between the said Richard Mall of Middle and Richard Higgins Churchwardens for the Parish of Middle in the said County of Salop (of the one part) and the above named Thomas France[s] of the other part) according to the Intent and Meaning of the same Indentures then this present Obligation to bee void and of none Effect or Else to bee and Remain in full power force and virtue

Sealed and delivered the paper being first stampt with three six penny stamps in pursuance to Thomas francis [signed] [seal] several acts of parliament in the sight and presence of us

Tho Tobey [signed] Richard Wedge [signed] ${ }^{84}$

As seen in the above example, the apprenticeship bond usually referenced the indenture and repeated some of the facts contained within it, such as the apprentice's name and residence, his or her father's name and residence, his or her master's or mistress's name and residence, and the length of the apprenticeship term. One key difference between the two types of documents was that in the bond the parish often took care to insure itself against the child later seeking parish

\footnotetext{
${ }^{84}$ Apprenticeship Bonds, 1672-1752, P201/L/9 (Shropshire Archives, Shrewsbury).
} 
relief. Consequently, a clause was regularly inserted that indemnified the parish and all its inhabitants from any costs that might arise from maintaining the child, as in the 1734 bond of Edward Davies abstracted below. This protected the parish in the event that the child might eventually fall on parish relief in its formally transferring the responsibility for the support of the child from the parish to the new master:

... in Case the said Samll Bellingham save Harmless \& Indempnified not only the above named Edward Hanmer and Joseph Cleaton Churchwardens of the Parrish of Middle aforesaid but also all other the Parishioners of the said Parrish from all \& all manner of Charges that the said Parishioners or any of them shall or may be put to for or by Reason of the maintenance Clothing or Bringing up of Edward Davies a Pauper of the said Parrish of Middle untill he shall accomplish the age of Twenty two yeares as is \& may more fully appeare ment[i]oned in one paire of Indentures of apprentice-ship wherein the said Edwd Hanmer \& Joseph Cleaton have Bound the s[ai]d Edward Davies to the said Samll Bellingham apprentice ... ${ }^{85}$

The forms of apprenticeship detailed in Myddle's apprenticeship documents include both pauper and charity apprenticeships. At least 71, or nearly three-quarters, of Myddle's 101 apprenticeships were associated with the endowment set up by the 1669 will of William Gough of Sweeney for the binding out of poor children within the community (see Figure 6.2 below). ${ }^{86}$ According to Gough's will, written in January 1667 and subsequently proved on 4 May 1669, the parish of Myddle was to receive:

The Sum[m]e of Five pounds upon every Five and Twentieth day of December To the Minister and Churchwardens of the parish Church of Midle in the said County for the tyme being for and towards setting out such poore children

\footnotetext{
${ }^{85}$ Note that the spacing has here been modified from the original text. Apprenticeship Bonds, 1672-1752, P201/L/9 (Shropshire Archives, Shrewsbury).

${ }^{86}$ The possibility remains that this number is an underestimation, as association with the Gough apprenticeship charity is typically only indicated in Myddle's apprenticeship indentures. In the cases where only a bond survives, this connection would not have been mentioned.
} 
Apprentices borne within the said parish as my said Cosen Richard Gough of Newton or his heires shall nominate allow and appoint ... ${ }^{87}$

Thus, due to his participation in parish administration and as part of his association with his uncle's charity, Richard Gough was himself often involved in the apprenticing of many of Myddle's disadvantaged children, his signature appearing on 33 documents (fifteen indentures and eighteen bonds) between roughly 1672 and 1716.

Although it appears that printed forms were in widespread use in English parishes from about the 1740s, they were in fact used sporadically in Myddle prior to this date. ${ }^{88}$ But although the first printed document appears in the 1686 indenture of Francis Davies, forms only constituted fifteen documents total (thirteen indentures and two bonds) of the apprenticeship documentation within Myddle's parish chest. In addition, the forms with their many alterations and addenda illustrate that bureaucratization was gradual and imperfect. They also speak to the limits of a center-focused approach to poor law administration and uncover how a universalized methodology did not always work in dealing with pauper children. On the contrary, flexibility was often required in dealing with the difficulties poorer families presented to the parish. The sources from Myddle moreover suggests the treatment of local poor children on a case-by-case basis. This type of management supports the view that parish officials were not always the heartless automatons bent on easing parish rates that some contemporaries - and historians have suggested.

\footnotetext{
${ }^{87}$ William Gough also specified the same type of arrangement for the nearby parish of Oswestry, for which he named his son-in-law Roger Evans as trustee. In addition, the minister there was to receive $6 \mathrm{~s} 8 \mathrm{~d}$ for the annual preaching of a sermon "in the English Tongue" on St. Stephen's Day. Nevertheless, the effect of this endowment appears to have been much less conspicuous in that parish, as it is not mentioned in Goodman's study of poor relief there, which reports that the only source of parish income was the poor rate, with the town of Oswestry itself boasting two charities that provided food and clothing for the poor. Will of William Gough, Gentleman of Sweeney, Shropshire, 4 May 1669, PROB 11/329/509, Prerogative Court of Canterbury Wills, 1384-1858, The National Archives, Kew, Richmond, Surrey; P. H. Goodman, "Eighteenth-Century Poor Law Administration in the Parish of Oswestry," Transactions of the Shropshire Archaeological Society 56 (1960): 338.

${ }^{88}$ Tate, 202.
} 
Other evidence substantiates this more benevolent interpretation of the motives of Myddle's parish officials throughout the latter seventeenth and eighteenth centuries, including the apprenticing of several pauper children to their fathers. The association between the poor law and the private sphere has long been noticed. Hindle comments that pauper apprenticeships were characterized by a reconstituting of the family. ${ }^{89}$ That an apprentice was prohibited from marrying without his or her master's consent was a standard clause in apprenticeship indentures of this period, a device that was more than just a textual prescription or formula and shows another way that apprenticeship influenced the shape of the early modern family. ${ }^{90}$

Moreover, the apprenticing of a pauper child within the child's own family, while unusual, was not without precedent. In the nearby Shropshire parish of Oswestry, young Vincent Boodle was apprenticed to his father, shoemaker Edward Boodle, in 1788. Although the reason is unstated, traditional interpretation has it that the likely motivation was the prevention of the family falling on parish relief, thus betraying parish officials' primarily fiscal concerns in presiding over the arrangement. ${ }^{91}$ In addition, the October 1765 settlement examination for William Garmstone, aged about twenty-five and born in Myddle, states that about thirteen years previous he had been set as an apprentice to his uncle Thomas Garmstone, ropier and also of Myddle, for five years. At the time of his examination, William had served just over two years

\footnotetext{
${ }^{89}$ Steve Hindle, On the Parish, 194-95.

${ }^{90}$ See Broad on how parishes with strong gentry influence - the Verney family of the Buckinghamshire village of Middle Claydon in the particular case Broad discusses - could assert a more general influence over who could marry whom. The Verney family's influence was so considerable that it extended not only to pauper marriages but to more well-to-do parishioners as well. Broad, 993-95.

${ }^{91}$ Goodman notes that this incident was "unusual." Perhaps it was so in Oswestry, but it does not appear to have been the case more widely. Elsewhere, Goodman offers a more balanced view of poor law administration in Oswestry by concluding that the system was in fact quite "humane," a fact which is not surprising when overseers in such a small community might often "have been related to those who sought relief." Goodman, 333, 340.
} 
of his apprenticeship. ${ }^{92}$ Although this instance appears to have been a private apprenticeship, it implies that apprenticing children to family members was not uncommon. It therefore follows that this pattern would hold with parish apprenticeships as well.

One reading of the evidence in these cases is that in Myddle parish officials attempted to reform, and not merely re-form, the family unit. Though the evidence is ambiguous, a sympathetic interpretation is that such bargains, though certainly working in the parish's financial favor, kept sons with their fathers and helped deserving families experiencing bouts of financial difficulty. Seen this way, these would have been arrangements from which all sides benefitted. Monetary advantages aside, they would have reinforced the bonds of the parish community and in this way are also perhaps an indication of the contours of Myddle's moral economy. ${ }^{93}$ What is clear no matter the exact motives is that these apprenticeships stood in contrast to those in which local children were apprenticed outside the family, not to mention those who were apprenticed outside the parish.

The particular examples from Myddle include eleven boys apprenticed to masters cited as their fathers. George Cooke was apprenticed to his mason father of the same name in 1721. It appears that George Cooke, Sr. himself took on additional apprentice mason, John Davies, described as a poor child of the parish, in 1732. Moreover, George Cooke, Jr. took on his son William Cooke as an apprentice in 1754, and later, in 1770, a Joseph Cook was apprenticed to his father George Cook in 1770 (though which George Cooke - younger, elder, or a relation - is unspecified). These examples strengthen the argument that stark lines between paupers and

\footnotetext{
${ }^{92}$ Myddle Parish (Shropshire), Settlement Examinations, 1717-1808, P201/L/3 (Shropshire Archives, Shrewsbury).

${ }^{93}$ On how charity in the form of the help-ale strengthened communal solidarity and at the same time illustrates the relative fluidity between charitable donor and recipient, see Judith M. Bennett's article: "Conviviality and Charity in Medieval and Early Modern England," Past \& Present 134 (February 1992): 19-41.
} 
respectable members of the community cannot be straightforwardly drawn. ${ }^{94}$ As well, these incidents reveal the reciprocity on which the parish system fundamentally rested, whereby George Cooke, Sr., a beneficiary of assistance from the parish in the apprenticing of his own son, and George Cooke, Jr., having received training himself, were now expected to do their parts in helping other needy children.

Other sons bound out to their fathers were John Broughall who was apprenticed to his weaver father, John Broughall, in 1722; Thomas Broughall, possibly a relation to the former, apprenticed as a weaver to his father, Samuel, of the parish of Whitchurch, in 1728; Martin Cheshire, Jr. to carpenter Martin Cheshire, Sr. in 1729; Thomas and William Cleaton to their father, Thomas Cleaton, a mason, in 1743 and 1745; John Reeves, Jr. to his weaver father, John Reeves, Sr., in 1752; John Millington to his father Robert Millington, a blacksmith, in 1762; and Jesse Manley to his father, Thomas Manley, a weaver, in $1799 .{ }^{95}$ In addition, it is highly probable, although not explicitly stated, that two additional children were bound out to family members: Edward Windsor, Jr., apprenticed to local farmer Edward Windsor, Sr. in 1675 and John Wycherley, bound out to mason Charles Wycherley in $1793 .{ }^{96}$ The inclusion of the above probable cases of children apprenticed to family members brings the total to thirteen individuals and takes in nine surnames. ${ }^{97}$

\footnotetext{
${ }^{94}$ In fact, in Oswestry it was not unheard of for children to be boarded out with individuals who themselves were on parish relief. Goodman, 329.

${ }^{95}$ Parish records confirm many of these relationships. Apprenticeship Indentures, 1672-1891, P201/L/8 (Shropshire Archives, Shrewsbury); Apprenticeship Bonds, 1672-1752, P201/L/9 (Shropshire Archives, Shrewsbury); W. P. W. Phillimore, ed., Registers of Myddle, Shropshire Parish Registers, Lichfield Diocese, vol. 19 ([Shropshire]: Shropshire Parish Register Society, 1931), 138, 145, 184, 193.

${ }^{96}$ Unfortunately, there is a large gap in Myddle's parish registers beginning with the disturbances of the Civil War and continuing into the Restoration (c.1645-1681) that prohibits the ascertaining of Edward Windsor, Jr.'s parentage. Registers of Myddle, 153.

${ }^{97}$ Apprenticeship Indentures, 1672-1891, P201/L/8 (Shropshire Archives, Shrewsbury).
} 
It must be qualified that these cases represent a minority of parish apprenticeships in Myddle. Even so, though not comprising a large proportion of Myddle's apprenticeships (15.5 per cent of male apprenticeships and 12.9 per cent all apprenticeships in the parish), they represent a type of apprenticing that, while perhaps uncommon, was utilized enough to become discernable in the records. The above examples indicate that when it was in some way practical, feasible, or desirable - at least from the point of view of parochial administrators - sons were apprenticed to their fathers. The churchwardens certainly had other options in apprenticing, ones that they in fact used in the majority of cases. Still, there must have been a reason for employing this particular type of arrangement even if it has become lost with time. Parish officials might have been attempting to ease the situation of a household likely in some sort of financial stress through the payment of an apprenticeship premium to the child's father as master. Alternatively, they might have been acting in their own - or the parish's - self-interest. Whichever the case, an important effect was that the household remained intact and members of the family were not dispersed either across county or parish, as sometimes occurred with pauper apprenticeships both in Myddle and elsewhere.

Discussion of spatiality brings up another key takeaway from Myddle's parish apprenticeship data. With regard to proximity, nearly all of Myddle's apprentices were either apprenticed in Myddle or sent to neighboring parishes within Shropshire. While the locations of two apprenticeships went unstated, 31 children (30.7 per cent) were apprenticed within Myddle itself. Of the 68 children apprenticed elsewhere, save four children (one bound out to Wales, two to Staffordshire, and one to Warwickshire), 64 of these were apprenticed within the county of Shropshire. Taking solely non-Myddle apprenticeships into account, the mean distance between Myddle and apprenticeship location was 8.9 miles. Thus, an overwhelming majority of 
Myddle's parish apprentices were apprenticed in nearby rural parishes and close to one-third of them served their terms within the parish itself.

It is surprising that only one child, Thomas Davies who was apprenticed as a cordwainer in 1687 , was bound out in the nearby market town of Shrewsbury. Soon after the beginning of his term Thomas was to be "enrolled according to the order and custome of the Corporac[i]on of Shrewsbury aforesaid" and at the end of the term, when he reached the age of twenty-four, he was to be made "a Freeman and Brother of the Company of Cordwainers or Corvisors" with the apprentice paying one half of the cost. ${ }^{98}$ Coupled with this case, the only other apprentice formally tied with the town was Francis Davies, who due to the closeness in date of their bindings and the fact that Thomas Davies was given as the father in both cases, was mostly likely a brother to the above-mentioned Thomas. Though Francis was apprenticed as a tailor within the parish of Clive in 1686, he was to be nonetheless "entered at Shrewsbury to the intent that at the end of the said terme he might be made a freeman of the company of Merchant Taylors of the said Town." 99

Shrewsbury (located about nine miles to the south of Myddle) had an economic draw on the countryside around it. The town had a weekly cloth-market, where cloth sold by farmers from the pastoral region of Wales to the town's west was sold to the Shrewsbury drapers' company. ${ }^{100}$ Shrewsbury's economic importance was well known. Daniel Defoe records the following about his journey to Shrewsbury in his A Tour through the Whole Island of Great Britain: Divided into Circuits or Journeys:

\footnotetext{
${ }^{98}$ Apprenticeship Indentures, 1672-1891, P201/L/8 (Shropshire Archives, Shrewsbury).

${ }^{99}$ Apprenticeship Bonds, 1672-1752, P201/L/9 (Shropshire Archives, Shrewsbury).

${ }^{100}$ Angus McInnes, "The Emergence of a Leisure Town: Shrewsbury, 1660-1760," Past \& Present 120 (August 1988): 54-55; Tomkins, 21-22.
} 
Over the market-house is kept a kind of Hall for the Manufactures, which are sold here weekly in very great Quantities: they speak all English in the Town, but on a Market-day you would think you were in Wales. Here is the largest Market, the greatest Plenty of good Provisions, and the cheapest, that is to be met within all the Western Part of England. ${ }^{101}$

Though the leather and textile trades entered a depression in the early eighteenth century, one of the suggested causes for the cloth industry's recession is that work contracted in the towns and cities at the same time as it expanded into the countryside, due to reduced costs, lower wages, and absence of guild restrictions in rural areas. ${ }^{102}$ While this development caused the cloth trade within the town to retrench, small-scale rural producers living in the parishes dotting the Shropshire countryside undoubtedly reaped the benefits, which in turn arguably influenced apprenticeship opportunities, including those involving pauper children. This might explain why so few of Myddle's apprenticeships were connected with Shrewsbury.

Regarding a wider geographic scope, there is the occasional child from Myddle who for unknown reasons is sent further afield, such as Arthur Noneley, who in 1682 was sent to Llandrinio, Montgomeryshire in Wales, and Anne Bickley, who was bound to Edward Davies to learn housewifery in Sutton Maddock, Shropshire, twenty-eight miles from Myddle, in 1718. After the mid-eighteenth century, three apprentices were sent to more distant places. Of these, Thomas Billings and Thomas Ellis were both bound to masters in Wolverhampton, Staffordshire, a burgeoning center of metalworking situated within the Black Country northwest of Birmingham, in 1751. Billings was apprenticed to a locksmith and Ellis to a forger. The third child was Thomas Blower, who was apprenticed to a ribbon weaver in Warwickshire in $1755{ }^{103}$

\footnotetext{
${ }^{101}$ Daniel Defoe, "Letter VII: A Description of Part of Cheshire, Northamptonshire, and Leicestershire" in $A$ Tour through the Whole Island of Great Britain: Divided into Circuits or Journeys, vol. 2 (London: 1748), 390-91.

${ }^{102}$ McInnes, 57.

${ }^{103}$ Apprenticeship Indentures, 1672-1891, P201/L/8 (Shropshire Archives, Shrewsbury).
} 
Still, sending local poor children to far-off parishes was decidedly unusual. Significantly, this was true even after 1692, when serving an apprenticeship legally conferred settlement in the parish of one's employment. Therefore, it appears that Myddle's parish officials did not use apprenticeship as a means of removing pauper children from the parish as a way of reducing parish expenditure on poor relief. Indeed, as demonstrated, in many cases the children were not in fact removed at all and served out their apprenticeships within the parish itself.

However, since parish documents only rarely record the consequences of a particular apprenticeship, the sources by their prescriptive nature tend to skew towards a rosy picture and care must be taken to explore the adverse aspects of pauper apprenticeship. ${ }^{104}$ Mistreatment was a common cause of an apprentice absconding, and within Myddle, there are hints at least of the possibility of maltreatment and abuse. ${ }^{105}$ The case of Daniel Beddow, who ran away from two different masters, personifies this point. ${ }^{106}$ While it is impossible to establish the historical reality - whether Beddow was truly of a bad character, as Richard Gough writes in The History of Myddle in his fulmination against the infamous family, or alternately, was horribly mistreated - his case certainly reveals how the system could be at times benevolent, and at others cruel.

Moreover, a pair of indentures for apprentice John Mercer illustrates the precarious nature of life for young apprentices. John's master, tailor Edward Brookes of Preston Gubbals, died soon after his original apprenticeship term began in 1678, and John was apprenticed

${ }^{104}$ Levene, "'Honesty, Sobriety and Diligence,"' 190.

${ }^{105}$ Hindle points out that pauper apprenticeship could be a highly controversial matter on several fronts, and sometimes involved disputes between parish officials and masters, the latter of whom sometimes proved to treat their apprentices so poorly that their charges ran away, something that appears to have been a perennial problem. Hindle, On the Parish, 209.

${ }^{106}$ Richard Gough, The History of Myddle, edited and with an introduction and notes by David G. Hey (New York: Dorset Press, 1986), 257; Apprenticeship Indentures, 1672-1891, P201/L/8 (Shropshire Archives, Shrewsbury). 
elsewhere to a new master in the parish of Clive in $1679 .{ }^{107}$ Whatever his ultimate feelings, it was unlikely that young John had any say in either of his appointments. Therefore, though such apprenticeships might have been carefully arranged by parish officials, the above sources allude to the more negative face of pauper apprenticeship.

These types of problems aside, an exploration of which trades young boys were apprenticed to in Myddle indicates parish officials' persistence in securing them decent, if not high status, livings. This is shown through frequent apprenticing to tailors, weaver, cordwainers, masons, and skilled laborers of varying sorts, which were the sorts of trades that made up the bulk of the rural non-agricultural workforce during the period, and relative infrequent apprenticing within agriculture. ${ }^{108}$ Apprenticeship in Myddle diverged from the archetypical binding out of pauper children out almost exclusively within the low-status occupation of agricultural labor. The evidence suggests how the availability of extra charity funds within a parish could alter the ways in which poor children were apprenticed. The treatment of pauper apprentices in Myddle undoubtedly reflects the fact that a good number of the parish's apprenticeships were funded through William Gough's endowment to the parish. The use of charitable funds by the parish to bind out one of Myddle's children was typically noted in an apprenticeship indenture, and these reserves enabled parish officials to be more generous to the children they considering deserving of their charity.

Gough's bequest resulted in the apprenticing of children within trades not connected with husbandry, the typical livelihood of the pauper apprentice, which parallels the findings of studies of charity apprenticeships elsewhere. For example, several of Myddle's children were

\footnotetext{
${ }^{107}$ Apprenticeship Indentures, 1672-1891, P201/L/8 (Shropshire Archives, Shrewsbury).

${ }^{108}$ Jon Stobart, "The Economic and Social Worlds of Rural Craftsmen-Retailers in Eighteenth-Century Cheshire," The Agricultural History Review 52, no. 2 (2004): 141.
} 
apprenticed to master weavers. In Simonton's study of apprenticeship in rural Essex and Staffordshire during the early eighteenth century, a large number of charity apprentices were set out in the textile trades, a fact that suggests that this was possibly "the alternative to agriculture for a poor but deserving child." ${ }^{109}$ Indeed, Simonton's findings mirror those from Myddle, in that the charity apprenticeships examined in her study similarly conformed more to the pattern of private apprenticeships than pauper ones. To compare Simonton's data with Myddle's, forty per cent of pauper apprentices in those counties were placed into husbandry or housewifery, while only a small number of boys - just seven - were bound out in Myddle in this fashion. ${ }^{110}$ Conversely, when Myddle's apprenticeships are compared with charity apprenticeships in Essex and Staffordshire, the evidence reveals that apprentices were similarly well treated in all three places. As will be shown, female apprentices were a much different case, however.

Whether the intentions of parish officials or regional economic conditions were more important in determining the trades into which poor children were apprenticed is difficult to say. Nonetheless, from the mid-seventeenth to the mid-eighteenth centuries, Myddle's male parish apprentices had the fortune to be apprenticed in a time of growing prosperity, showing how the economy could at times play as important a role as parish officials in determining their fate. Many rural crafts, including tailoring and cordwaining, experienced growth in the beginning half of the eighteenth century. ${ }^{111}$ In the period from 1660 to 1760 real wages were also rising. In Shrewsbury, for example, the wages earned by a master mason rose from $1 \mathrm{~s} 6 \mathrm{~d}$ per day in the 1690 s to 2 s $6 \mathrm{~d}$ per day in 1775 , and though the increase was less marked, laborers also saw their

\footnotetext{
${ }^{109}$ Simonton, 241.

${ }^{110}$ Simonton, 241.

${ }^{111}$ Stobart, 145 .
} 
wages surge, from $10 \mathrm{~d}$ per day in 1690 to $1 \mathrm{~s} 4 \mathrm{~d}$ per day by the 1770 s. $^{112}$ Although tailors and cordwainers were some of the most variable occupations in terms of social status and could run the gamut from nearly impoverished to quite prosperous, there was nevertheless a large market share, considering that by the dawn of the nineteenth century both ready- and custom-made clothing were commonly purchased, even by lower-class rural wage earners. ${ }^{113}$ The end result of these conditions was that more could be bought with less, even for an apprentice in a lowerstatus, non-agricultural trade like cordwaining, at a time when more people in general were buying.

However, it must be noted that some of the evidence is nonetheless clouded in ambiguity, such as the apprenticing of several children to their fathers, which can alternately be read as an attempt at moral reform, a bid to reduce parish costs, or an effort to help a struggling local family. In truth, it is probable that these instances reflect an amalgamation of all of these concerns and that a simple distillation distorts the complicated reality of early modern poor relief in the rural English parish. The best that can be said is that it seems that compassion towards the poor children of the parish is most perceptible when monetarily and morally advantageous circumstances converged.

As well, this more considerate attitude toward poor children perceivable in Myddle, as distinct from the harsher treatment of the parish's adult poor, might also suggest the outlook, voiced in An Ease for Overseers of the Poor regarding the ultimate redeemable nature of poor children. Unlike adults, who had a stark choice between idleness and profitable employment,

\footnotetext{
${ }^{112}$ McInnes in fact identifies rising wages and a concomitant flattening out in the price of consumables as but two of the many factors in Shrewsbury's transformation into a center of leisure during the Restoration. McInnes, 76-77.

${ }^{113}$ Christina Fowler, "Robert Mansbridge: A Rural Tailor and His Customers, 1811-1815," Textile History 28, no. 1 (1997): 29-38; Stobart, 143.
} 
poor children had the bad luck of an unfortunate upbringing. Here, the author presents a fairly compassionate posture towards poor orphan children, whose situation was ultimately to be improved via the exercising of communal responsibility, at least until the child could provide for him- or herself, that is:

when poor orphans and others be left fatherlesse and motherlesse to the world, and by reason of their tender yeares, cannot worke, or be unable to live of [f] their worke, it is fitte [that] they should have releefe: for if the bird will cherish her yong till they bee able to flie, wee are bound by nature to nourish these till they be able to shift. ${ }^{114}$

The ultimate object was to remove a child from a harmful environment and place him or her into a more proper one in which the respectable values and work ethic could be taught. In this way, their ties to their inadequate upbringings would lessen, for the children would be "more bound to their tutors that teach them howe to live well, then [sic] to their parents that gave them life." ${ }^{115}$ Pauper apprenticeship offered a poor child a chance at an honorable living.

In Myddle, while most times effort was made to secure boys reasonable, if humble, livelihoods, female apprenticeship in the parish presented a much different face. The evidence reveals that a gendered moral economy subsisted in Myddle, whereby male apprentices were generally treated more benevolently. The differences are telling. First, female apprentices were far rarer, representing just over 16.8 per cent of Myddle's apprenticeships. This number itself is revealing. As does some of the other evidence, it marks a departure from the usual pattern of pauper apprenticeships, given that other studies find that as one went down the scale - from private to pauper apprentices - female apprentices tended to climb in number. ${ }^{116}$ It is quite

${ }^{114}$ An Ease for Overseers of the Poore, 25.

${ }^{115}$ An Ease for Overseers of the Poore, 26.

${ }^{116}$ According to Simonton, girls made up nearly one-third of parish apprentices in Essex and Staffordshire in the latter half of the eighteenth century. In Myddle, they only constituted eleven out of fifty-nine, or approximately twenty-two per cent of total apprentices. Simonton, 245. 
possible that apprenticeships for girls were less likely to be recorded, but this does bring up an important point in itself: that apprenticeship for girls was possibly more informal than apprenticeship for boys. Other dynamics to be considered include the possibilities that boy apprenticeships might purely have been easier for officials to secure, that girls were considered more useful to the domestic economy, or due to their vulnerability to sexual immorality girls were thought to be best protected at home. ${ }^{117}$ In fact, it is easy to see how some of these stimuli might have reinforced one another. Nevertheless, even though only a relatively small number of girls - seventeen - were documented as apprenticed by officials Myddle, their treatment emerges as an important feature.

While boys were more liable to be officially apprenticed in the first place, they were also more likely to be contracted using the parish's charitable funds. Whereas 62 out of 84 boys (73.8 per cent) were apprenticed in association with Myddle's apprenticeship charity, girls were less likely to be bound out in such a way (see Figure 6.2 below). Nine out of seventeen girls (52.9 per cent) - were apprenticed through the use of charitable resources. ${ }^{118}$

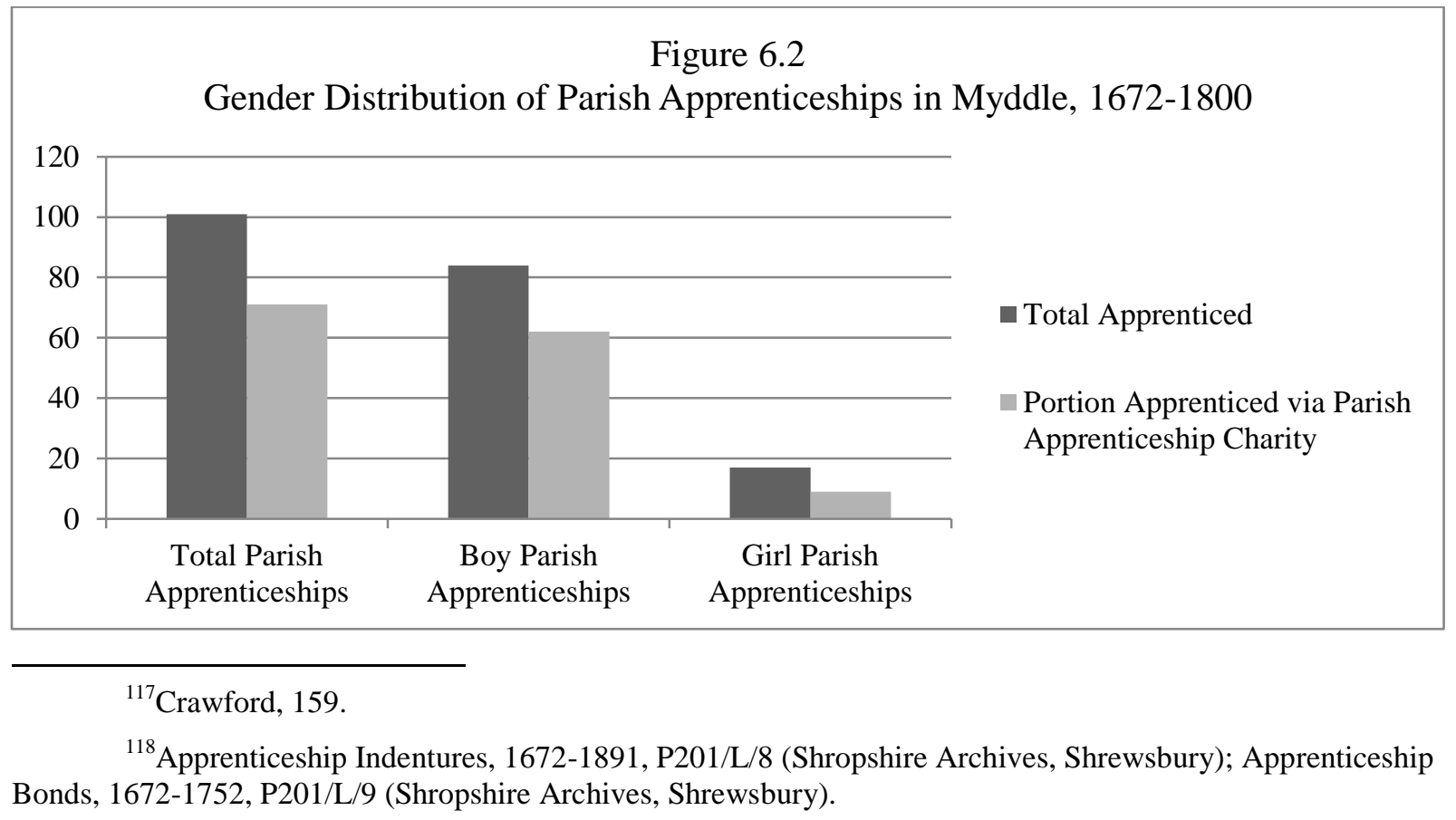


Another indicator of different treatment is that in contrast to poor boys in the parish who were generally sent to learn non-agricultural, skilled trades, girls were more commonly apprenticed in either housewifery or to a master in a lower-ranking trade, such as husbandry. One exception was Elizabeth Brethren, who was apprenticed to stonecutter Obadiah Ikin in 1747, with the indenture nonetheless noting that Elizabeth was to be trained in housewifery and, pointedly, not a formal occupation. ${ }^{119}$ In fact, just four girls were apprenticed to specified trades, all connected with the textile industry: one girl was bound out as a tow dresser ${ }^{120}$ in 1716 and three as stay and mantua makers, all in the latter half of the eighteenth century. All four of these apprenticeships were supported through the parish apprenticeship charity, indicating that when girls were set into skilled trades, they were more apt to receive charitable support. Still, most girls in Myddle were apprenticed into low-status work, indicating several important facts. First, their labor was not valued. ${ }^{121}$ Girls were more unlikely to be apprenticed at all, and when they were, their bindings were less likely to be charitably financed. What this suggests is that they were far less often considered to be of the deserving poor than boys.

The master-to-apprentice sex ratio is further indicative of the devaluation of female labor. Except for Samuel Bellingham, who was apprenticed to learn husbandry in the service of local inkeeper and widow Frances Bate in 1757, all other boys in Myddle were apprenticed to men, something not necessarily surprising or unusual. Female mistresses were even rare when binding out young girls, however. Only three female apprentices were specifically bound out to mistresses: Jane Guest, who was to be trained in housewifery by Mary Williams of Newton-onthe-Hill in Myddle in 1726; Letitia Edge, who was apprenticed to mantua maker Ann Roberts in

${ }^{119}$ Apprenticeship Indentures, 1672-1891, P201/L/8 (Shropshire Archives, Shrewsbury).

${ }^{120}$ A tow dresser prepared flax for spinning. W. H. R. Curtler, A Short History of English Agriculture (New York: Clarendon Press, 1909), 251.

${ }^{121}$ Simonton, 244. 
the parish of Overton, Shropshire in 1774; and Ann Thomas, who was bound out to Ann Carr, also a mantua maker, of Myddle in 1791. In 1748, Ann Blower was apprenticed to George and Abigail Chidlow who were to train her in housewifery, and was the only child apprenticed to a husband and wife jointly. ${ }^{122}$

Although it is likely that even when young girls were officially apprenticed to men they were in reality trained by the female head of household, the official documents elide this fact. Two of the four girls from Myddle apprenticed into named trades were apprenticed to mistresses. Though the sample from Myddle is small, the evidence seems to indicate that if a girl were to learn a trade, the odds that she would be apprenticed to a woman were somewhat higher than if she were to be trained in housewifery. These findings too match those concerning Essex and Staffordshire, where almost all - ninety-nine per cent - of boys were apprenticed to men, as well the vast majority of girls. In fact, in those places the involvement of female mistresses generally stood at below four per cent, even in the trade of housewifery. ${ }^{123}$

In a reflection of the legal restrains placed upon women through the concept of coverture, both publicly and authoritatively, most young women were bound out to masters rather than mistresses. Coverture was "the common law idea that during marriage a husband's authority and legal identity covered his wife's." ${ }^{124}$ This legal principle was demonstrated by the fact that apprenticeship agreements, including several in Myddle, sometimes spelled out that a female apprentice's term of service was to end either after the end of the specified term, or marriage,

${ }^{122}$ Apprenticeship Indentures, 1672-1891, P201/L/8 (Shropshire Archives, Shrewsbury); Apprenticeship Bonds, 1672-1752, P201/L/9 (Shropshire Archives, Shrewsbury).

${ }^{123}$ Simonton, 251.

${ }^{124}$ Tim Stretton and Krista Kesselring, eds. Married Women and the Law: Coverture in England and the Common Law World (Montreal and Kingston: McGill-Queen's University Press, 2013), 3. 
whichever came first. ${ }^{125}$ As a wife was not an independent actor, coverture also explains why girls were apprenticed to men. Furthermore, despite the fact that the poor laws considerably complicated women's roles - legally, women could simultaneously be wage-earning laborers and dependents, for example - the implementation of the poor laws remained colored by coverture in the sense that women could not be considered liable to provide support for their more destitute family members. ${ }^{126}$ Officially, then, this meant that the financial contribution of married women to the household was "immaterial." ${ }^{127}$ The evidence uncovered here thus further underscores the general low regard to which women's work was held not only in Myddle but in England more widely. In this respect, Myddle is typical of other English parishes of the time.

Since it was the commonest trade to which young girls in Myddle were apprenticed, just what was expected of a girl apprenticed in housewifery? Gervase Markham's The English Huswife: Containing the Inward and Outward Vertues Which Ought to be in a Compleate Woman, published in London in 1623, gives some indication, if not of the reality, then at least of the prescriptive ideal. Markham, who published prodigiously on a wide range of subjects throughout the seventeenth century, largely discusses medical home remedies for common ailments, and gives advice on cookery, baking, dairying, beer making, and distilling and winemaking. He also includes instruction in other domestic household tasks, such as dyeing and spinning wool, cultivating flax, and preparing linen, activities that had the potential to add a modest profit to the household coffers. As well, Markham incorporates material on the

\footnotetext{
${ }^{125}$ Apprenticeship Indentures, 1672-1891, P201/L/8 (Shropshire Archives, Shrewsbury); Apprenticeship Bonds, 1672-1752, P201/L/9 (Shropshire Archives, Shrewsbury).

${ }^{126}$ If they themselves were not impoverished, a pauper was to be supported by his or her family members according to the poor laws. Marvin B. Sussman, "Law and Legal Systems: The Family Connection," in Family and Support Systems across the Life Span, ed. Suzanne K. Steinmetz (New York: Plenum Press, 1988), 26.

${ }^{127}$ Kim Kippen, "Poor Law, Coverture, and Maintaining Relations in King's Bench, 1601-1834" in Married Women and the Law: Coverture in England and the Common Law World, ed. Tim Stretton and Krista Kesselring (Montreal and Kingston: McGill-Queen's University Press, 2013), 77.
} 
cultivating and harvesting of oats. But, voluminous as some of this material is, the care of the bodily health of the housewife's family, it seems, was second only to the proper moral and religious behavior of the female head of household: "the preservation and care of the family touching their health and soundnesse of body" was "one of the most principall vertues which doth belong to our English hous-wife."128

The inclusion of extra educational and religious training to be given to Myddle's pauper apprentices within some indentures reveals interesting differences in the treatment of boy and girl apprentices. They also suggest changing ideas about the responsibilities of a master or mistress to his or her charge. Prior to 1750, four of Myddle's female apprenticeship indentures contain clauses regarding education to be provided during apprenticeship. These included Anne Bickley, apprenticed to miller Edward Davies in 1718, who was to receive reading and religious instruction; Jane Guest, who was apprenticed to local widow Mary Williams in 1726 (one of the few above examples of a girl apprenticed to a mistress) was to receive three months' schooling or instruction by her family in order that she be taught to read during the course of her apprenticeship; and Ann Blower, bound out in 1748 to married couple George and Abigail Chidlow of Loppington, was to be instructed in reading. Elizabeth Brethren, apprenticed to stonecutter Obadiah Ikin in 1747 , too was to receive training in reading as well as "sewing, and other such business[e]s ... usuall and fitting for such women to Learn and be employed in ..." Elizabeth's master was also "to bring or cause his said apprentice to be brought yearly and every year on each Lord[']s day during the said term to Church and there to stay till divine service be ended unless sickness or some other extraordinary business can or may happen." Although this is the first instance in Myddle of this kind of stipulation regarding church attendance, as time

\footnotetext{
${ }^{128}$ Gervase Markham, Country Contentments, or The English Huswife: Containing the Inward and Outward Vertues Which Ought to be in a Compleate Woman (London, 1623), 4, EEBO, accessed 3 March 2014, http://gate way.proquest.com/openurl?ctx_ver=Z39.88-2003\&res_id=xri:eebo\&rft_id=xri:eebo:citation:99847308.
} 
wore on it came to become a standard inclusion in many apprenticeship indentures - involving both boys and girls - beginning in the 1760 s. ${ }^{129}$ This might well indicate the tendency to look at the poor more so as a homogenous group, and a change in emphasis that placed more importance on class over gender.

It is tempting to conclude that clauses delineating extra education appear to disclose a more positive concern for female apprentices in Myddle. That Jane could be taught by her family is perhaps further evidence for reforming and improving the poor family through apprenticeship, as opposed to reconstructing it via the new master's household. However, such stipulations, combined with the other key features of parish apprenticeship in Myddle - fewer incidences of female apprenticing, less likelihood to utilize charitable funds by parish officials in such cases, and the male-dominated master-to-apprentice sex ratio - more likely reveal that for young girls, being trained in a supportive, household-focused role was more important as learning hands-on skills related to a specific trade. ${ }^{130}$

Both male and female indentures, at least before the mid-seventeenth century, commonly contained the language typical of such documents of the late medieval period, referring to the apprentice's prohibition from contracting marriage, playing dice, committing fornication, visiting taverns or alehouses, and the like. ${ }^{131}$ Myddle's indentures conform to such customs, with one modification being the incorporation church attendance as part of apprenticeship training starting in the mid-eighteenth century. However, these conventions notwithstanding, no male indentures contained similar educational clauses like those found in the above female indentures. Boys' contracts, it seems, did not require the spelling out of such additional accommodations. The

\footnotetext{
${ }^{129}$ Apprenticeship Indentures, 1672-1891, P201/L/8 (Shropshire Archives, Shrewsbury); Apprenticeship Bonds, 1672-1752, P201/L/9 (Shropshire Archives, Shrewsbury).

${ }^{130}$ Simonton, 234.

${ }^{131}$ Tate, 225; Nicholas Orme, Medieval Children (New Haven: Yale University Press, 2001), 312.
} 
male apprentice's role in the domestic hierarchy of his master's household order, though not without its own sources of conflict, tended to be relatively well defined; this sense of order does not seem to have characterized female apprenticeship so tidily, at least officially. ${ }^{132}$ For example, as with the formal apprenticing of girls to masters when their training was likely overseen by a female figure, visibility within the records is again problematic. On this problem, Simonton states that we must firstly recognize that "[a]pprenticeship was only one form of educating girls for adult roles, and a great many children, especially girls, did not experience formal apprenticeship. For them other forms of education and upbringing such as family, schooling, work or informal arrangements were significant." ${ }^{133}$ The overall impression is that male apprenticeship was normative, and when this was not so, allowances - through such things as religious and educational clauses - had to be made. This is a picture, also seen in Myddle's settlement records, that neatly ties with the value placed on male labor.

Although the very real problem of lack of evidence is undoubtedly the case - and must be recognized - other influences are at work as well. Due to the sin of Eve, women were regarded as the more morally vulnerable of the two sexes. ${ }^{134}$ The fact that Anne Bickley was to be instructed in religious matters can be seen as part of the overall effort to instill the proper cultural values into a poor child likely brought up undisciplined and irreligious, as contemporaries often envisioned the poor children of the parish. However, girls came under additional scrutiny, and there is much evidence that period female advice literature "made it clear that girls' moral upbringing was of paramount concern to the middle classes." ${ }^{135}$ As well, it appears that male

\footnotetext{
${ }^{132}$ Laura Gowing, Domestic Dangers: Women, Words, and Sex in Early Modern London (New York: Oxford University Press, 1998), 15.

${ }^{133}$ Simonton, 234.

${ }^{134}$ Gowing, 3 .

${ }^{135}$ Simonton, 253.
} 
and female apprentices posed different dangers to their masters' households: boys for example presented a "greater physical threat" than girls, who were in turn "more likely to affect the moral or sexual integrity of a household or business than its physical well-being." ${ }^{136}$ Morality, involving as it did expressions of power, was highly gendered. In a general sense, it operated within "a culture that perceived women's virtue, honour, and reputation through their sexuality, [and] men's through a much wider range of values." 137

Contemporary sources also speak of the importance of religion in connection with female obedience and submissiveness. Markham for instance writes that the housewife, regarding her "inward vertues," should:

above all things ... be of an upright and sincere religion, and in the same both zealous and constant; giving by her example, an incitement and spurre unto all her family to pursue the same steppes, and to utter forth by the instruction of her life, those vertuous fruits of good living, which shall be pleasing both to God and his creatures; I do not meane that herein she should utter forth that viole[n]ce of spirit which many of our (vainely accounted pure) women do, drawing a contempt upon the ordinary Ministery, and thinking nothing lawful but the fantazies of their own inventions, usurping to themselves a power of preaching and interpreting the holy word, to which only they ought to be but hearers and beleevers, or at the most but modest perswaders, this is not the office either of good Hous-wife or good woman. But let our english Hus-wife be a godly, constant, and religious woman, learning from the worthy Preacher \& her husband, those good examples which shee shall with all carefull diligence see exercised amongst her servants. ${ }^{138}$

After all, vice often entered the household through the mother, its most vulnerable member. Examples abound in Gough's writings of this perception, most notably with the family of the above-mentioned apprentice Daniel Beddow (described more fully in chapters two and three), whose amorality Gough pointedly blames not on Daniel's drunken father, Humphrey

\footnotetext{
${ }^{136}$ Levene, "'Honesty, Sobriety and Diligence,"'190.

${ }^{137}$ Gowing, 2 .

${ }^{138}$ Markham, 2.
} 
Beddow, but on his maternal grandmother, Sina Davies. ${ }^{139}$ It was moral failings within the family such as these that such educational clauses were likely meant to resolve. Clearly, the constitution of the boy pauper apprentice was to be improved through the teaching of a proper work ethic, and he was offered a chance at a decent living through his apprenticing into and training in respectable trades. The girl pauper apprentice's chance at improvement, on the other hand, predominantly rested in the far more cloistered sphere of morality.

\section{Conclusions: Pauper Apprenticeship in Myddle}

This study of Myddle's 101 pauper apprentices in many ways paints a positive picture. The presence of an apprenticeship charity appears to have changed the dynamics of pauper apprenticeship in Myddle, and the documentary record demonstrates that male apprentices could be treated surprisingly well. This is exemplified by the binding out of apprentices either within the parish itself or in adjacent rural parishes even after it would have been financially advantageous to have done not so according to late seventeenth-century settlement guidelines. As well, the relatively low levels of apprenticing in agriculture indicate that parish officials did not view their parochial charges as mere sources of drudge labor to be exported to other locales. Other evidence suggests a more complex picture. Though it appears that eleven boys were apprenticed to their fathers, the ultimate purpose behind these contracts remains obscure. What can be said, however, is that such arrangements were multifaceted and likely had many motives - some moral, some financial, others perhaps in the interest of neighborly and communal harmony.

Girls in Myddle do not appear to have reaped these same benefits, however. They were far rarer and made up a much smaller number of the apprentices set out by the parish. Girls were

\footnotetext{
${ }^{139}$ Gough, 257-58.
} 
also less likely to have been bound out through the parish's apprenticeship charity. While 62 out of 84 boys (73.8 per cent) were apprenticed through the parish's apprenticeship charity, just nine out of 17 girls were apprenticed in this way. Moreover, when girls were apprenticed, they were overwhelmingly to be trained in housewifery instead of a formal trade. Furthermore, most of Myddle's female apprentices were bound out to masters.

Still, the picture was a complex one. On the one hand, all of this speaks of the low appreciation for activities regarded as "women's work." However, evidence of this type, as Simonton comments, "is not to suggest that women's work was not skilled or important, but that it was not recognized as such through apprenticeship," something as true for Myddle as it was for eighteenth-century Essex and Staffordshire. ${ }^{140}$ Women's contributions to the domestic economy through housewifery were in fact considered vital to the management and economic success of the household. ${ }^{141}$ Nevertheless, women's and children's labor were connected in that both were often needed in times of "crisis," and it was a commonplace that their labor was supplementary to that of the male head of household. ${ }^{142}$ Another important point is that even if it was often "occasional, intermittent, and interchangeable" when compared to men's work, many women did work outside the purview of the household, but their occupational identities tended to be masked in official sources by their marital ones. ${ }^{143}$

Another important feature of Myddle's apprenticeship records is that before the mideighteenth century, only girls had additional educational and religious addenda appended to their apprenticeship agreements. These supplemental instructions suggest some recognition of the

\footnotetext{
${ }^{140}$ Simonton, 254-55.

${ }^{141}$ Waddell, 90-91.

${ }^{142}$ Waddell, 93, 102.

${ }^{143}$ Luciano Allegra, "Becoming Poor in Eighteenth-Century Turin," Journal of Interdisciplinary History,
} 46, No. 2 (Autumn 2015): 171. 
lower status of women in society. Girls were less likely to receive instruction in things like reading to begin with, thus the obligation by parish officials to make such requirements clear. They also reflected that such additions were considered necessary for female apprentices, who were adjudged as more morally susceptible than male apprentices. This attitude did not appear to be consistent, however. Starting in the 1760s, many indentures began to spell out the necessity for masters and mistresses to ensure that their apprentices attend church, perhaps revealing hardening attitudes to poor children in general and of the need to reform their moral character through religious instruction.

This raises an important point, for though the story is more pessimistic for female apprentices, this does not mean that it was wholly optimistic for male apprentices in Myddle. Even when not funded by charitable funds, apprenticeship was often the cheapest option for the parish in dealing with its poor children. ${ }^{144}$ Thus, even for boys it appears that the financial economy still governed the moral one. Indeed, it was the former that made the latter possible, if not for all of the poor children of the parish, then at least for those found "deserving." This itself was a complex problem and gendered concept ultimately left in the hands of local officials to resolve.

${ }^{144}$ Anthony Brundage, The English Poor Laws, 1700-1930 (New York: Palgrave, 2002), 16. 


\section{CHA P T E R 7: C O N CLUS I O N}

\section{Summary of Findings}

Richard Gough's writings represent a hierarchical treatment of the parish of Myddle, reflecting the paternalistic biases of parish elites and their prejudices concerning class and gender and demonstrating the subjectivity of belonging in the parish community. ${ }^{1}$ The History of Myddle shares important characteristics with pre-1834 poor law administration. In many ways, the former can be viewed as a narrative version of the latter, adding depth and individual stories to the brief and formulaic documents that catalogue poor law administration in the parish.

In addition, the eight settlement cases Gough writes about in The History of Myddle show an overarching concern over parish finances as well as anxieties about the morality of the poor. Through the poor laws' legal concept of settlement, a concept open to a good deal of interpretation at the local level, these settlement cases demonstrate how the concept was quite flexible. It was determined by local officials using a number of criteria, including age, gender, marital status, family size, and perhaps most significantly, the likelihood of a person falling on parish relief and representing a financial liability for the parish. Settlement was also a gendered construct. For men, the parish of one's last employment was a key factor in determining settlement. In contrast, settlement for women and children was more derivative and connected to that of the male head of household. At the same time, their settlement was more so tied to lifecycle events like marriages and births than men's. Thus, Gough's The History of Myddle is important to the study of the early modern English parish not only because of its importance as a uniquely colorful work of local history, but also because it offers a glimpse into the minds of those allocating parish resources through the day-to-day implementation of the poor laws. As

\footnotetext{
${ }^{1}$ Richard Gough, The History of Myddle, edited and with an introduction and notes by David G. Hey (New York: Dorset Press, 1986).
} 
well, the work reveals how parish officials judged local paupers' moral characters. In short, The History of Myddle serves as a key to understanding why parochial administrators sometimes made the decisions they made.

Later chapters of this study move the focus away from Gough and what his writings reveal about Myddle, to examine what parish documents add to questions concerning the treatment of Myddle's poor. For example, Myddle's settlement examinations, removal orders, and settlement certificates echo some of the themes prevalent in Gough's writings, and reveal the importance of documents such as hiring contracts, for example, in establishing settlement. These records also uncover the value placed upon the labor of single men, the relative suspicion that men and women with dependents often came under, and thus, the ways in which poverty was a variable experience. Parish records also go a bit beyond Gough's narrative to hint at some of the grim realities of life for the poor. At its heart, their existence was characterized by itinerancy and an unstable sense of belonging that was ultimately defined by parish elites.

Continuing with some of the above themes, examination of the ways in which illegitimacy was dealt with both in The History of Myddle and parish documents, reveals that single mothers were especially vulnerable to removal. In his writings, Gough treats the moral transgression of bastardy as but one element in a web of disrepute. Condemnation for it was also class dependent and connected to the parish rates. This meant that a mother and her child were judged the harshest when they were dependent on parish support. While analysis of illegitimacy in Myddle is admittedly hampered by lack of parish documentation, the documents nevertheless suggest repeated instances of bastardy among certain individuals and surnames within the parish. It is also crucial to recognize that Myddle's surviving bastardy bonds are gendered documents, in their emphasis on both a man's financial culpability in siring a bastard and uncovering the 
patriarchal power structure of the parish. Women were judged more harshly than men for the offense. However, despite the gendering of such conventions, both men and women who were guilty of bastardy were held accountable for their violations of perceived notions of respectability, albeit in different ways.

The evidence from Myddle clearly shows the hazards of handily summarizing the treatment of the community's poor or distilling their experiences down into a one-size-fits-all model. It was inevitable that nearly all governmental attempts at centralization through poor law initiatives "tended to founder on local economic interests." ${ }^{2}$ In effect, there was not so much "a" moral economy as a multitude. This is best characterized by consideration of the parish's setting out of pauper apprentices. In many ways, the poor children placed as pauper apprentices by the parish formed an exception to the harsher attitudes of parish officials to other types of Myddle's poor. This was due to the existence of a parish apprenticeship charity that allowed for the relatively compassionate treatment of poor children in the parish. Even so, this practice held mostly for boys. Compared to girls, boys in the parish were more often apprenticed, more frequently bound out using charitable funds, more regularly apprenticed to family members, and by and large tended to be sent into non-agricultural, skilled trades. In other words, Myddle's male apprentices were not typically bound out as agricultural laborers, which tended to be true of pauper apprentices. Still, a key point is that even in the apprenticing of boys in Myddle, the existence of charitable funds was likely the main cause of their benevolent treatment, and it is quite likely that their situation would have been harsher had this not been the case. ${ }^{3}$ From the

\footnotetext{
${ }^{2}$ Anne Digby, Pauper Palaces (London: Routledge \& Kegan Paul, 1978), 229-30.

${ }^{3}$ As outlined in chapter six, the model that the apprenticing of boys in Myddle best resembles is the pattern of charity apprenticeships discerned by Deborah Simonton in her examination of apprenticeship in early eighteenthcentury Essex and Staffordshire. In this study, when compared with charity apprentices, pauper apprentices were markedly less well treated. Deborah Simonton, "Apprenticeship: Training and Gender in Early Eighteenth-Century
} 
parish's point of view, the bottom line was all-important and the preservation of it was also affected in interesting ways by social and cultural influences.

\section{The Late Eighteenth Century}

Due to the periodization of this study, it is necessary to outline changes to the poor laws that came with the late eighteenth century, what these meant for Myddle, and situate in a general sense the transition to the New Poor Law. The poor laws underwent a gradual process of change during the late eighteenth and nineteenth centuries as the system was progressively modified and developed from one centered on the parish into one based instead around poor law unions, administrative units that often comprised several parishes. ${ }^{4}$ The Elizabethan Poor Law of 1601 had simply codified and universalized aspects of poor law management already being practiced, albeit in a localized, patchwork fashion. In a similar way, when the New Poor Law was passed in 1834, marking a definitive end to the parish-based system, many facets of the law had already been put in place. ${ }^{5}$ Like the Old Poor Law, the New Poor Law also defies easy characterization, and while the eighteenth century saw several legislative changes as well as philosophical shifts in terms of the poor laws, in many cases these were based on existing practices and ideas. ${ }^{6}$

One feature that bridged the old and new systems was the persistence of local variation in the face of attempts to standardize poor relief. ${ }^{7}$ For example, although they would become a defining characteristic of the New Poor Law, workhouses were an important precursor with a

England," in Markets and Manufacture in Early Industrial Europe, ed. Maxine Berg (New York: Routledge, Chapman and Hall, 1991), 241.

${ }^{4}$ Digby, 32.

${ }^{5}$ David R. Green for instance calls attention to the fact that "with the exception of a centralised bureaucracy" many features of the New Poor Law were already in place. David R. Green, Pauper Capital: London and the Poor Law, 1790-1870 (New York: Routledge, 2016), 11.

${ }^{6}$ Steven King, Poverty and Welfare in England, 1700-1850: A Regional Perspective (Manchester: Manchester University Press, 2000), 67.

${ }^{7}$ Steven King, Poverty and Welfare in England, 230. 
complicated - and locality-dependent - history. In fact, the first parish housing for the local paupers supported by local ratepayers dated back to the seventeenth century. ${ }^{8}$ While settlement legislation was directed primarily towards controlling the movement of the unsettled poor, the objective of these early workhouses was to relieve the settled impotent poor. ${ }^{9}$ This was related to cultural ideas concerning poverty, namely, the distinction made between the deserving and undeserving poor, or those would not work versus who could not work. In the nineteenth century workhouses would mainly be meant for the able-bodied, betraying the eventual evolution of their role, but workhouses often shifted back and forth between aiming to serve the impotent and able-bodied poor throughout the eighteenth century. The main impetus for their creation in the earlier part of the century was the problem of dealing with the able-bodied poor, however; and, while they were neither as ubiquitous nor institutionalized as they would become in the nineteenth century, several workhouses were built in this period across the country. ${ }^{10}$

As the eighteenth century progressed, several factors came together that added incentive to workhouse initiatives. There had been appeals for poor law reform in the seventeenth century both during the Interregnum and after the Restoration. ${ }^{11}$ There were various reasons why these calls failed, important ones being the inability to garner enough support for proposed legislation to carry both houses of Parliament and the reluctance of those in power to interfere with such a complex and expensive component of local government. ${ }^{12}$ The late seventeenth century saw more attempts at reform when the costs of relief were thought to have risen and there were new

\footnotetext{
${ }^{8}$ Anthony Brundage, The English Poor Laws, 1700-1930 (New York: Palgrave, 2002), 11.

${ }^{9}$ Brundage, 11.

${ }^{10}$ Brundage, 11.

${ }^{11}$ Joanna Innes, "The 'Mixed Economy of Welfare' in Early Modern England: Assessments of the Options from Hale to Malthus (c. 1683-1803)," in Charity Self-Interest and Welfare in the English Past, ed. M. J. Daunton (New York: St. Martin's Press, 1996), 147.

${ }^{12}$ Innes, 147.
} 
calls to put the able-bodied poor to work. ${ }^{13}$ A harsher attitude toward the poor seems to have taken hold in the beginning years of the eighteenth century, which emphasized not only the artificial limitations the poor laws placed upon the free market, but also both the need for mechanisms of control for the ill-disciplined able-bodied poor and the necessity of inducing them to work. ${ }^{14}$ As well, in the late seventeenth century, figures such as legal scholar Matthew Hale and economist Josiah Child seem to have advocated for workhouses as a solution to the problem of the able-bodied poor following their investigation of similar institutions in Holland. ${ }^{15}$ However, in general, in England workhouses were normally more enduring and successful in urban areas, and in rural areas appear to have been more transitory experimentations than permanent organizations during the late-seventeenth and eighteenth centuries. ${ }^{16}$

During the eighteenth century, two pieces of legislation encouraged workhouse schemes. A 1723 act, known variously as the Workhouse Test Act, the General Act, or Knatchbull's Act, was passed. The new law only permitted parishes to ally, and was not a mandatory directive, nor was the resultant practice universal, but it allowed groups of parishes to collaborate by local act in either building workhouses or contracting out the care of local paupers to private entities. ${ }^{17}$

\footnotetext{
${ }^{13}$ Innes, 147-49.

${ }^{14}$ Paul Slack, The English Poor Law, 1531-1782 (New York: Cambridge University Press, 1990), 33; Brundage, 11-12.

${ }^{15}$ Before comparing England's system of poor relief to those of Holland, Hamburg, and New England, which according to him all maintained schemes for employing the poor, Child writes: "it is our Duty to God and Nature so to Provide for, and Employ the Poor [emphasis added]." Josiah Child, A Method Concerning the Relief and Employment of the Poor Humbly Offer'd to the Consideration of the King and Both Houses of Parliament (London, 1699), 4, Early English Books Online (EEBO), accessed 17 February 2014, http://gateway.proquest.com/ openurl?ctx_ver=Z39.88-2003\&res_id=xri:eebo\&rft_id=xri:eebo:citation:12952483; see also Matthew Hale, $A$ Discourse Touching Provision for the Poor (London, 1683), 5-A5, EEBO, accessed 17 February 2014, http://gateway.proquest. com/openurl?ctx_ver=Z39.88-2003\&res_id=xri:eebo\&rft_id=xri:eebo: citation:13115847; Mary Lindemann, Patriots and Paupers: Hamburg, 1712-1830 (New York: Oxford University Press, 1990), 24; Innes, 150; Brundage, 11.

${ }^{16}$ Slack and Brundage mention the urban workhouses of London, Bristol, Exeter, Hereford, Colchester, Norwich, King's Lynn, Gloucester, and Plymouth, for example. Slack, 33; Brundage, 11.

${ }^{17}$ J. D. Marshall, The Old Poor Law, 1795-1834 (New York: The MacMillan Press Ltd, 1968), 14; Brundage, 12.
} 
The law also dictated that if a pauper refused the workhouse, he or she could be refused all parish relief. $^{18}$

Another bill was passed in 1782 allowing parishes to join together in unions to set up workhouses at the urging of Lichfield MP Thomas Gilbert, from whom such unions would eventually take their name. Gilbert himself had a sympathetic view of the wandering poor, the vagrants who were often punished by the Elizabethan law, the cause of whose rambling he felt resulted from want of employment. ${ }^{19}$ Gilbert's ultimate aim was to make the system of poor relief more efficient, replacing unpaid overseers with paid officials who would be better suited to administering to the particular challenges of poor relief. ${ }^{20}$

In order for local incorporation to occur, a two-thirds majority of local ratepayers and landowners was required. The resulting workhouses were meant to accommodate children, the elderly, and the impotent poor. Although the able-bodied were prevented from being housed there, parishes were still required to offer outdoor relief, which in the period from 1780 to 1834 could include allowances-in-aid-of-wages; reimbursement to local ratepayers for the rotational employment of paupers within the parish through the roundsman system; the labor rate, a modified version of the roundsman system that came to be used in the $1820 \mathrm{~s}$; and payments to underemployed and unemployed laborers and laborers with large families. ${ }^{21}$ As with the Workhouse Test Act, Gilbert's Act never became compulsory and an attempt to render it

\footnotetext{
${ }^{18}$ Brundage, 12.

${ }^{19}$ Steven King notes that owing to its origins, namely its outgrowth from the desire to control vagrancy, the Old Poor Law had always been "greated to confronting pauperism rather than treating and preventing poverty and destitution." Raymond G. Cowherd, "The Humanitarian Reform of the English Poor Laws from 1782 to 1815 ," The Proceedings of the American Philosophical Society, 104, no. 3 (June 1960): 330-31; Steven King, Poverty and Welfare in England, 21.

${ }^{20}$ Cowherd, 330 .

${ }^{21}$ George R. Boyer, An Economic History of the English Poor Law (New York: Cambridge University Press, 1990), 10, 17-18; Lynn Hollen Lees, The Solidarities of Strangers: The English Poor Laws and the People, 1700-1948 (New York: Cambridge University Press, 1998) 103-4.
} 
mandatory failed in 1786 . Nevertheless, by 1834 across the country some 924 parishes had joined into 67 Gilbert Unions. In this way, the building of workhouses in this period tended to be the result of one of two basic processes: by local act, per the 1723 law, or via that sponsored by Gilbert in $1782 .^{22}$

The effects of local workhouses were mixed. Where they were built, parish relief did not cease and worked in tandem with the workhouse. The main purposes of workhouses seem to have been inculcating a work ethic amongst the poor and, importantly, alleviating the financial liability of local ratepayers. ${ }^{23}$ Indeed, it seems that the last goal was not often met, as parishes that adopted workhouses while persisting with aspects of the old relief system were instead hit with the financial burdens of both schemes. ${ }^{24}$ As well, as a result of the process of unionization, local power became even more concentrated. Workhouse unions marked the greater distillation of power into the reaches of the upper classes, in their wresting of control away from parish overseers into the hands of more prosperous tenant farmers, magistrates, and country gentlemen. ${ }^{25}$ From an ideological perspective, for officials the new litmus test was not a moral one, the workhouse itself forming its own "test" for applicants of relief. ${ }^{26}$ Though it is important to stress the gradual evolution of poor relief, the fact that rate-based aid had never replaced voluntary charity, and the continued desire to morally reform the poor, immorality had at least in

\footnotetext{
${ }^{22}$ Incorporation by local act occurred mainly in urban areas, became more common after 1750, and was associated particularly with East Anglia. The years between 1674 and 1833 saw 196 incorporations, 125 via local act and 71 via Gilbert's Act. Brundage, 21; Green, 10.

${ }^{23}$ Steve Hindle, On the Parish?: The Micro-Politics of Poor Relief in Rural England, c.1550-1750 (New York: Oxford University Press, 2004), 188.

${ }^{24}$ Digby, who outlines the growth in Norfolk of houses of industry, notes that parishes that chose to do both "got the economic disadvantages of both a parochial and a centralized system" and notices that "[p]rofound disillusionment had followed when the formation of local incorporations had failed to produce a decline in the poor rates." Digby, 48.

${ }^{25}$ Brundage, 21.

${ }^{26}$ Brundage, 12 .
} 
this sense become immaterial. ${ }^{27}$ This last change in particular marked a distinct break from the old system. But, in the end there was a mixture of both continuity and change, and many features of the late seventeenth- and eighteenth-century poor laws eventually made their way into the New Poor Law.

Despite these initiatives, the poor law system remained inherently local in the late eighteenth and early nineteenth century. Largely because calls for national and comprehensive reform of the poor laws had failed in the eighteenth century, local legislation was the avenue by which changes were made in the late 1740 s, via local incorporation. ${ }^{28}$ The agency of each parish in charting its own response to poverty was considerable and the resulting enterprises often mixed together the old and new. For example, due to the disappointment that a decline in parish rates had not been prompted following the incorporation of several Norfolk parishes, several parishes in that county returned to the Old Poor Law system in the early nineteenth century, increasing outdoor relief and operating workhouses as poorhouses rather than houses of industry. $^{29}$

Still, the 1790s also marked a clear turning point, engendering many of the debates that would become central to the passing of a new poor law in the next century. The influence was not just academic, as the difficult conditions of the last decade of the eighteenth century helped spur several pieces of legislation that would later become key parts of the New Poor Law. From roughly the 1720 s to the 1750 s, poor relief expenditures appear to have held generally steady with a few brief exceptions; however, during the 1790s, Britain experienced poor weather and

\footnotetext{
${ }^{27}$ Innes, 168.

${ }^{28}$ Innes, 161.

${ }^{29}$ This particular phenomenon was seemingly not confined to Norfolk. Raymond G. Cowherd reports that the 1803 abstract of returns relative to the state of the poor indicate that by that time most workhouses were utilized as poorhouses. Cowherd, 341; Digby, 47-48.
} 
bad harvests, which caused food prices to rise. ${ }^{30}$ To these problems were added the stresses of a larger population, higher rates of unemployment, inflation, and rising poor rates. ${ }^{31}$ All this alone was enough to lead to harsher assessments of the poor laws, but the political turmoil on the Continent related to the French Revolution and subsequent French Revolutionary and Napoleonic Wars added an even sharper concern: that of the poor's "revolutionary potential." ${ }^{32}$

These worries caused both a conservative backlash as well as a liberal response, the effects of which would be used by critics to lambaste the poor laws as encouraging pauperization and advocate their replacement with a more punitive, and in their view practical, system. ${ }^{33}$ Raymond G. Cowherd envisions the period from the late eighteenth century to the early years of the nineteenth as characterized by a conflict between natural law reformers, including Thomas Robert Malthus, Joseph Townsend, and Sir Frederic Morton Eden, on the one hand, and humanitarian reformers, such as Sir George Rose, on the other. ${ }^{34}$ For example, Rose was influential in the abolishing of the practice of removing of individuals deemed likely to seek relief from their parishes of settlement in 1795; after that point, only those who had actually requested relief were eligible for removal. ${ }^{35}$ In that same year, individuals no longer had to enter the workhouse in order to gain assistance. ${ }^{36}$ And, although it was never centralized on a national scale, another important development was the gradual growth of the allowance, or Speenhamland, system, which consisted of wage supplements (usually, but not always in the

\footnotetext{
${ }^{30}$ Slack, 34; Brundage, 25.

${ }^{31}$ J. D. Marshall estimates that between around 1784 to the end of the Napoleonic Wars in 1815, poor relief expenditures had risen between two and three times. J. D. Marshall, 23; Brundage, 25.

${ }^{32}$ Brundage, 25.

${ }^{33}$ See Brundage for an outline of these various, and often clashing, responses. Brundage, 25-29.

${ }^{34}$ Cowherd, 332, 340, 342; Steven King, Poverty and Welfare in England, 24-25,

${ }^{35}$ Cowherd, 333; Brundage, 26.

${ }^{36}$ Cowherd, 334 .
} 
form of money) given out by the parish to help support laborers and their families. ${ }^{37}$ Another scheme that came into use during the eighteenth century, mainly in the southern and eastern English counties, was the roundsman system, which involved settled laborers performing rotational work for farmers to ameliorate local un- and underemployment. Workers' salaries were funded jointly through the parish poor rate and by the farmers themselves. ${ }^{38}$

In the realm of philosophy and political thought, two key figures affecting poor law policy - and importantly, ideas about the poor - were Jeremy Bentham and Thomas Robert Malthus. Bentham highlighted deterrence as a strategy to deal with poverty. ${ }^{39}$ Bentham's theory of Utilitarianism emphasized rationality as the solution to social problems. Famously, Bentham's litmus test was what would produce "the greatest good for the greatest number" something arrived at through "[t]he cold, searching glare of reason." ${ }^{40}$ Because it was a threat to the whole social order, in his eyes, poor relief necessitated centralization. Bentham, voicing what would become a common theme, also felt that the morality of the poor was inconsequential, as were the attempts by parish officials to try to sort them into the deserving and undeserving: instead, the workhouse and its test would now do this work for them. ${ }^{41}$

But, it was arguably Malthus who would go on to have the greater long-term effect on ideas about poverty, in his influential work, An Essay on the Principle of Population, originally published anonymously in $1798 .^{42}$ Although comprehensive change would not come for some time, Malthus provided one of the leading voices advocating that the poor laws needed broad

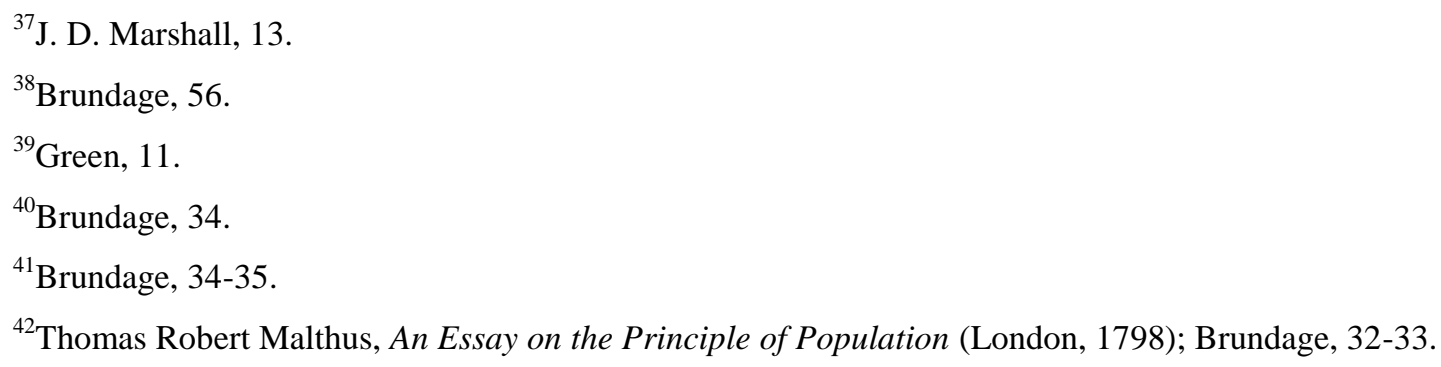


reform. ${ }^{43}$ Contributing to the new cynicism regarding poverty and the poor that grew up in the late eighteenth century, Malthus's work was significant for a number of reasons. ${ }^{44}$ Malthus, writing in a time of rising poverty and poor relief costs, saw the poor laws as encouraging poverty and maintained that population increase was detrimental to society, and not "a sign of national vigour," as had been previously supposed. ${ }^{45}$ Malthus's Essay, in its anti-Enlightenment bent, countered the ideas of William Godwin and the Marquis de Condorcet, which centered on the perfectibility of society, and honed in on the phenomenon of population growth versus subsistence. ${ }^{46}$ For example, in contrast to Godwin, who maintained that more food would lead to more population and thus to more human happiness, the key tenet of Malthus's paradigm was that left "unchecked" population increased geometrically, while subsistence increased arithmetically. ${ }^{47}$ It was not happiness that was the defining factor in or result of population growth, but instead vice and unchecked growth, which were perpetually and inescapably followed by misery and want. ${ }^{48}$

In this period, Malthus was not the only writer generating material critical of Godwin, however. Malthus's work was not only anti-Godwinian in the narrow sense that it engaged with the ideas of Godwin himself, but also in a broader, anti-Jacobin one as well. ${ }^{49}$ Seen in this way,

${ }^{43}$ Green, 8 .

${ }^{44}$ Green, 6 .

${ }^{45}$ Green, 7-8.

${ }^{46}$ Brundage, 33; Donald Rutherford, "Malthus and Three Approaches to Solving the Population Problem," Population 62, No. 2 (2007): 217, 230.

${ }^{47}$ Malthus, 6.

${ }^{48}$ Gail Bederman, "Sex, Scandal, Satire, and Population in 1798: Revisiting Malthus's First 'Essay,"' Journal of British Studies 47, no. 4 (October 2008), 791.

${ }^{49}$ For example, as an illustration of taking Malthus's work as part of a more general condemnation of Godwin, Bederman examines Malthus's 1798 Essay as a response to and condemnation of not only Godwin, but also his unorthodox relationship with and the feminine sexuality of his wife, feminist Mary Wollstonecraft. Bederman, $779-84,793$. 
the ideas of Godwin and others were a proxy for the Catholic French "other," against which an eighteenth-century British identity was molded, as a result of war and fear of invasion. ${ }^{50}$ But, in addition to the chaotic reverberations across Europe produced by the French Revolution, all of the difficult conditions of the 1790 s - population growth, bad harvests, rising food prices, and high unemployment - stood as important ingredients of the historical context within which Malthus produced his Essay. Additionally, particularly after 1795, there were new concerns over the poor laws when demands for relief increased due to bad harvests and increased taxation due to war. ${ }^{51}$ These were all important factors that affected his writings.

These things colored his highly-critical views of the poor laws in particular, which Malthus saw as self-perpetuating, memorably observing that they encouraged unrestrained population growth and served to "create the poor which they maintain." ${ }^{52}$ Dedicating chapter five to a discussion of the poor laws and examining what he considered their prevailing inclination towards self-defeat, Malthus writes:

To remedy the frequent distresses of the common people, the poor laws of England have been instituted; but it is to be feared that though they may have alleviated a little the intensity of individual misfortune, they have spread the general evil over a much larger surface. It is a subject often started in conversation and mentioned always as a matter of great surprise that notwithstanding the immense sum that is annually collected for the poor in England, there is still so much distress among them. Some think that the money must be embezzled, others that the church-wardens and overseers consume the greater part of it in dinners. All agree that some how or other it must be very illmanaged. $^{53}$

\footnotetext{
${ }^{50}$ This proposition is the primary focus of Linda Colley's Britons: Forging the Nation, 1707-1837, which probes the collaborative process of the formation of British identity. Linda Colley, Britons: Forging the Nation, 1707-1837, rev. ed. (New Haven: Yale University Press, 2009).

${ }^{51}$ Cowherd, 334-35; Bederman, 770.

${ }^{52}$ Malthus, 34.

${ }^{53}$ Malthus, 32.
} 
The poor laws were so dangerous, according to Malthus, because in providing "subsistence to all" they artificially masked the miseries of poverty that under normal circumstances provided a "preventative check" on population growth. ${ }^{54}$

In Malthus's mind, the poor laws served to increase prices and depress the value of labor. They also discouraged the underprivileged from thrift, industriousness, and sobriety, all familiar themes that hound the poor within Gough's writings:

I feel no doubt whatever that the parish laws of England have contributed to raise the price of provisions and to lower the real price of labour. They have therefore contributed to impoverish that class of people whose only possession is their labour. It is also difficult to suppose that they have not powerfully contributed to generate that carelessness and want of frugality observable among the poor, so contrary to the disposition frequently to be remarked among petty tradesmen and small farmers. The labouring poor, to use a vulgar expression seem always to live from hand to mouth. Their present wants employ their whole attention, and they seldom think of the future. Even when they have an opportunity of saving they seldom exercise it, but all that is beyond their present necessities goes, generally speaking, to the ale-house. The poor-laws of England may therefore be said to diminish both the power and the will to save among the common people, and thus to weaken one of the strongest incentives to sobriety and industry, and consequently to happiness. ${ }^{55}$

As did eighteenth-century reformers in the German city of Hamburg, who felt that financial resources "had been squandered on the poor in the form of alms and inexpedient bequests, which had done little or nothing to relieve poverty but much to abet idleness," Malthus echoed the desire to make the underemployed and underproductive poor industrious, to the benefit of society and the state. ${ }^{56}$

\footnotetext{
${ }^{54}$ Hans E. Jensen, "The Development of T. R. Malthus's Institutionalist Approach to the Cure of Poverty: From Punishment of the Poor to Investment in Their Human Capital," Review of Social Economy 57, no. 4 (December 1999): 455; Brundage, 32.

${ }^{55}$ Malthus, 35-36.

${ }^{56}$ Lindemann, 76-77.
} 
Malthus saw the poor laws as limiting in another way: the settlement laws restricted the poor's freedom and liberty. In this sense, Malthus is sympathetic to the poor. Despite the undoubted "benevolent" motive behind the poor laws, Malthus decries the settlement laws as causing "the whole class of the common people of England" to be:

subjected to a set of grating, inconvenient, and tyrannical laws, totally inconsistent with the genuine spirit of the constitution. The whole business of settlements, even in its present amended state, is utterly contradictory to all ideas of freedom. The parish persecution of men whose families are likely to become chargeable, and of poor women who are near lying-in, is a most disgraceful and disgusting tyranny. ${ }^{57}$

In addition, it is significant that frequently embedded in Malthus's comments is criticism of local officials, whom he suggests had been wasteful in handing out relief and at times cruel to the poor. And, in reproach to the localism inherent in poor law administration, he additionally criticizes the "tyranny" of local officials, which he regards as not always stemming from their own shortcomings but instead was brought about by defects within the poor law system itself. ${ }^{58}$ Malthus's solution, or "palliative," was a three-part program that displayed the influence of Utilitarianism and was meant to "increase the mass of happiness among the common people in England." ${ }^{59}$ First, was the abolition of the existing poor laws, which would then "give liberty and freedom of action to the peasantry of England" and allow them to "be able to settle without interruption, wherever there was a prospect of a greater plenty of work and a higher price for their labour." ${ }^{60}$ Second, Malthus felt that premiums should be paid and other inducements given to boost agriculture. This was so agricultural wages would not be depressed below those of

\footnotetext{
${ }^{57}$ Malthus, 37.

${ }^{58}$ Malthus, 38.

${ }^{59}$ Malthus, 38.

${ }^{60}$ Malthus, 38.
} 
manufacturing and trade and the country would be able to produce enough food. Last, Malthus encouraged the setting up of county workhouses, which were not to be "comfortable asylums," but places where "[t]he fare should be hard" in order to except all but the most severe cases of need. $^{61}$

\section{Myddle and the Evolution of Poor Relief}

Myddle's system of poor relief continued to evolve as the eighteenth century progressed.

The 1776 abstract of the returns made by overseers of the poor show that Myddle raised in 1776 $£ 8317 \mathrm{~s} 3 \mathrm{~d}$ and out of that money on account of the poor expended $£ 6218 \mathrm{~s} 6 \mathrm{~d}$. The parish expended no parish funds in litigation regarding the settlement and removal of paupers. ${ }^{62}$ Myddle also paid $£ 31$ s for the rent of workhouses and habitation for the poor. Although several other parishes within the county of Shropshire did, at that time, Myddle did not have a workhouse. ${ }^{63}$ This would change in the 1790s with Myddle's incorporation, along with several other parishes, into the Ellesmere Union.

The Shropshire town of Shrewsbury was incorporated in 1784 by an Act of Parliament, the six parishes within it cooperating in maintaining a workhouse, probably as a result of Gilbert's Act (1782). ${ }^{64}$ This was not just an isolated phenomenon within the county, nor

\footnotetext{
${ }^{61}$ Malthus, 39.

${ }^{62}$ Great Britain, Parliament, House of Commons, Reports from Committees of the House of Commons, vol. 9, Provisions Poor, 1774-1802 ([n.p.], 1803), 443.

${ }^{63}$ Figures in parentheses refer to the number of workhouses followed by the number of persons able to be accommodated (although original, geographic order of the entries has been modified, the original spelling has been retained): Baschurch (1/6), Bishops Castle, Borough [of] (1/25), Brosley (1/40), Buildwas (1/12), Chetwynd (1/-), Church Stretton (1/66), Claverley (1/20), Cleobury Mortimer (1/60), Drayton in Hales (1/75), Edgmond (1/16), Eellsmere (1/45), Hales Owen (1/260), Hodnett (1/20), Holy Cross [Shrewsbury] (1/30), Leighton (1/20), Ludlow, Town [of] (1/40), Lydham (1/12), Madeley (1/20), Much [Wenlock] (1/30), Newport (1/18), Oswestry (1/30), Oswestry, Town [of] (1/30), Pontesbury (1/20), Preese (1/60), St. Alkmond [Shrewsbury] (1/15), St. Chad [Shrewsbury] (1/80), St. Julian [Shrewsbury] (1/26), St. Mary [Shrewsbury] (1/40), Shiffnal (1/40), Wellington (1/56), Wem (1/30), Westbury (1/24), Whitchurch (1/40), Whittington (1/20), Worfield (1/12), Worthen (1/-). Reports from Committees of the House of Commons, 441-44.

${ }^{64}$ Frederick Morton Eden, The State of the Poor: A History of the Labouring Classes in England with Parochial Reports, ed. A. G. L. Rogers (New York: E. P. Dutton \& Company, 1929), 296.
} 
exclusively an urban one. Parishes in Shropshire, a county made up of a varied assortment of industrial and agricultural and urban and rural, seem to have been involved in a healthy number of incorporations in the late eighteenth century. ${ }^{65}$ For instance, between 1783 and 1791 several parishes within Shropshire were combined, including the Incorporations of Shrewsbury, Atcham, Whitchurch, Oswestry, and Ellesmere. ${ }^{66}$ The last incorporation affected Myddle, and took in the rural and agricultural parishes of Ellesmere, Baschurch, Hordley, Myddle, and the chapelry of Hadnall, which were incorporated in 1791 by an Act of Parliament, with a workhouse built the next year at Haughton, Ellesmere. ${ }^{67}$ This basic arrangement held until 1836, when after the implementation of the New Poor Law, this workhouse became the official workhouse of Ellesmere Union and took in several other local parishes in addition to those that had been incorporated earlier, in $1791 .^{68}$

Myddle's inclusion in the Ellesmere incorporation was an important administrative change in that it signaled the parish's move away from the parochial system of poor relief. Despite the fact that incorporations occurred throughout the eighteenth century, they were not very common. The 1803 Abstract of Returns Relative to the State of the Poor indicate that of the 14,611 "parishes or places," contained within, only 26 per cent maintained workhouses. ${ }^{69}$ Myddle's choice to incorporate, an orgnizational change reflected within the parish's vestry minutes, was therefore a somewhat uncommon one. On 4 May 1794, there is the first mention of a parish meeting regarding the appointment of officeholders to serve as directors of the new

\footnotetext{
${ }^{65}$ Vincent J. Walsh, "The Old and New Poor Laws in Shropshire, 1820-1870," Midland History 2, no. 4 (1974): 225.

${ }^{66}$ Walsh, 225; Alannah Tomkins, The Experience of Poverty, 1723-82: Parish, Charity and Credit (Manchester: Manchester University Press, 2006), 39.

${ }^{67}$ Eden, 294; Walsh, 237.

${ }^{68}$ Walsh, 233.

${ }^{69}$ J. S. Taylor, "The Unreformed Workhouse, 1776-1834," in Comparative Development in Social Welfare, ed. E. W. Martin (London: Allen and Unwin, 1972, 62-63, 76, cited in Boyer, 266.
} 
incorporation, dubbed "the United Parishes." ${ }^{70}$ Notations of this type continue throughout the 1790s. Moreover, minutes from September 1794 record the ensuing removal of the poor to the new workhouse at Haughton. ${ }^{71}$ In the post-workhouse period, the 1803 Abstract of Returns Relative to the State of the Poor show that Myddle expended $£ 104$ 6s 4d on poor relief and provided outdoor relief to 35 adults, 4 children under the age of five years, and 5 individuals who were either over 60 years of age, disabled, or infirm, with 19 individuals relieved occasionally by the parish. ${ }^{72}$ Incorporation was perhaps a sign of parish officials' desire to harness the labor of the poor for profitable activities and encourage moral reform, or a program of financiallymotivated deterrence. ${ }^{73}$ The exact motivation is not possible to determine, but the relative infrequency of workhouse inititatives means that Myddle's incorporation was a noteworthy development.

\section{The Reproblematization of Belonging}

On the surface, Richard Gough and Thomas Robert Malthus were very different figures, their works springing from different places, chronologically and topically. While there is debate over the extent to which Malthus's experiences ministering the rural chapelry of Okewood, Surrey influenced his writings, it is clear that Gough's experiences in parish office-holding colored his views of some of the individuals about whom he wrote. ${ }^{74}$ Indeed, Gough's writings are so enmeshed with Myddle, that it is difficult to imagine him without place as his leitmotif. Gough was an inherently local creature, whereas Malthus was seemingly unaffected by his

\footnotetext{
${ }^{70}$ Vestry Minutes, Poor Allowances, 1793-1800, P201, Fiche 179 (Shropshire Archives, Shrewsbury).

${ }^{71}$ Vestry Minutes, Poor Allowances, 1793-1800, P201, Fiche 179 (Shropshire Archives, Shrewsbury).

${ }^{72}$ Great Britain, Parliament, House of Commons, Abstract of the Answers and Returns Made Pursuant to an Act, Passed in the 43d Year of His Majesty King George III, Intituled 'An Act for Procuring Returns Relative to the Expence and Maintenance of the Poor in England' ([London], 1804), 418-19.

${ }^{73}$ Boyer, 22-23.

${ }^{74}$ Bederman, 770-1, 777.
} 
surroundings. In this sense, Gough and Malthus were shaped by different forces, and in their juxtaposition can be seen the collision of localism versus centralization, the individual versus the larger mechanism. Not inconsequentially, Gough viewed individual character as the key to one's respectability. This, to him, was a mutable thing, shaped and limited by the constraints of class and gender, but still changeable. For Malthus, the factors driving population growth, and by extension human nature, were inexorable, unchangeable except by external forces largely beyond the control of an individual's willpower.

Yet, the two men shared certain similarities. Despite being an Anglican clergyman and therefore of a higher social status, Malthus was not unlike Gough. Both numbered among the parish elite. The two men certainly shared a love of order. Neither man seemed to possess a good deal of sympathy for the poor, with the abiding image of Malthus as "a sober country parson." ${ }^{75}$ Moreover, Gough's writings show the idea that the poor laws encouraged poverty and idleness had existed long before Malthus. ${ }^{76}$ An interesting question is whether the end of the eighteenth century was a world Gough, who had died some seventy-five years earlier, in 1723, would have recognized. It must be said that he almost certainly would have applauded some of its tenets, such as the aim to reduce the parish ratepayer's burden. As Myddle's records show, albeit infused with morality and other social and cultural forces, the bottom line had always been one of the bellwethers - indeed, perhaps the most important one - of poor law administration in Myddle. In this way, both men were fundamentally rational in understanding poverty.

Several elements about poor relief in Myddle materialize within this study, the most important of which is its complexity and tendency to defy easy summation. First, the records

\footnotetext{
${ }^{75}$ Bederman, 778.

${ }^{76}$ In fact, these concerns predated even Gough, and had existed since at least the late seventeenth century. Innes, 157.
} 
show how settlement was flexible and was an issue over which parish elites had a fair amount of discretion. Poverty was unstable: those who experienced it suffered instability, but this instability was often felt in different ways and to differing degrees by Myddle's various types of poor. The labor of single men posed the least monetary threat to the parish and this is why, of the poor, their belonging was the most stable. Second, illegitimacy was both a moral and financial threat to the parish. It is also the best example of poverty as a gendered experience. For example, the way it was dealt with showed the vulnerability of single mothers to moral blame and parochial removal. This gendering was also exemplified by the ways men transgressed their roles as financial providers to their families by fathering illegitimate children. Third, pauper children in the parish were treated leniently and with apparent sympathy, but even this was moderated by, first, funds from a parish apprenticeship charity and, second, attitudes about gender. Last, parish apprenticeship hints at the possible ways that the poor interacted with the Old Poor Law as families and not just as individuals.

Recalling Steve Hindle's postulation of a spectrum of parochial belonging, the overriding impression from Gough as a historical source is that everyone had their place in Myddle and was aware of the expectations society made of them. ${ }^{77}$ Moreover, when these were either upheld or contravened, there was a certain cultural script Gough read from in alternately lauding good behavior or criticizing misconduct, the basic text of which was shaped by attitudes about class and gender. In addition, Gough's writings and parish sources demonstrate how family and gender as analytical categories help trace the lines of ill repute. Bastardy in particular epitomized how disreputability, as with the Beddow family, was characterized by the interrelationship of character traits like lewdness, indolence, deceipt, and wastefulness. There

\footnotetext{
${ }^{77}$ Steve Hindle, "The Problem of Pauper Marriage in Seventeenth-Century England," Transactions of the Royal Historical Society, 6th ser., 8 (1998): 89.
} 
were exceptions to every rule, however, and the sources from Myddle show the webs of positive reputation, primarily earned through thrift, industriousness, and moderation, characterized by poor weaver William Parkes and his disabled daughter Anne, that allowed some paupers to belong to the parish community. Conversely, The History of Myddle also illustrates the ways in which those of the upper classes, as in the case of the lazy and immoral Michael Chambre, could descend from decency through decadence and licentiousness, providing an adjunct to the sometimes repressive impression given by Myddle's parish chest records. In sum, membership in the parish through both belonging and respectability came from a complex network of considerations.

Although certain principles about poor relief had clear antecedents, poverty started to become a larger problem in Myddle as the eighteenth century advanced. It is important to recognize that the Old Poor Law system was made up of several laws passed throughout a period of over two hundred years, and as such was never a static system. For these reasons, and others, Old Poor Law generalities are difficult. In some places and at some times, the system administered by local elites was generous and in other places and at other times it was unkind. Indeed, poor law administration in Myddle seems to have functioned in this somewhat variable manner.

There was an admixture of both continuity and change in the transition from the Old Poor Law to the New, and even with the formation of unions, local variations persisted. ${ }^{78}$ Even so, the Old Poor Law's parochial organization was such that a person in need of relief "did not have to apply to a remote bureaucratic authority" but instead had to travel usually no more than two or

\footnotetext{
${ }^{78}$ Green, 14 .
} 
three miles to appeal to overseers of the poor who likely knew the claimant personally. ${ }^{79}$ By integrating the roughly 15,500 parishes across the country into some 600 unions, the New Poor Law succeeded in establishing "an entirely new administrative grid across the country" altering much of the above scenario. ${ }^{80}$ One important change was that in the process of transcending the parish and encompassing larger unions, some of "the communal context" of the Old Poor Law, which had been embodied by paternalism, deference, and mutuality, was lost. ${ }^{81}$

As well, there was an overarching trajectory that in later periods led to poverty being seen via the comfortable distance of statistics and more so in terms of class than as a condition. As the poor became quantifiable, they emerged as a result as a faceless and homogenous group. ${ }^{82}$ With this shift, the poor were no longer defined in terms of being "neighbors" or "strangers," or "deserving" or "undeserving," but by economic fluctuations and calculations, laborers who in times times of dearth became "the poor." 83 In this way, the long and winding road from Myddle led to Cross Bones, where the poor have arguably remained as an abstraction ever since.

\footnotetext{
${ }^{79}$ Thomas Sokoll, "Institutional Context: The Practice of Non-Resident Relief," in Essex Pauper Letters, 1731-1837 (New York: Oxford University Press, 2001), 10-11.

${ }^{80}$ Green, 2.

${ }^{81}$ Green, 13.

${ }^{82}$ Sandra Sherman, Imagining Poverty: Quantification and the Decline of Paternalism (Columbus: Ohio State University Press, 2001), 3. See also Green, 13-15.

${ }^{83}$ Lindemann, 51.
} 


\section{BIBLIOGRAPHY}

\section{Primary Sources}

\section{Unpublished Materials}

Court of Quarter Sessions of the Peace (Shropshire). Quarter Sessions Rolls, 1696-1971. Q/S/5. Shropshire Archives, Shrewsbury.

—. Quarter Sessions Order Book, 1709-1726. Q/S/1. Shropshire Archives, Shrewsbury.

—. Quarter Session Minutes, 1708-1971. Q/S/3. Shropshire Archives, Shrewsbury.

Gough, Richard. Antiquities and Memoyres of the Parish of Myddle (original manuscript), 1700, 1525/1. Shropshire Archives, Shrewsbury.

Myddle Parish (Shropshire). Parish Registers for Myddle, 1541-1942. Shropshire County Record Office, Shrewsbury. Family History Library (FHL) microfilms 1,701,254 items 9-15; 1,702,085 items 8-16. FHL, Salt Lake City, Utah.

- Bishop's Transcripts for Myddle, 1632-1850. Shropshire County Record Office, Shrewsbury. FHL microfilm 501,459 item 1; FHL microfilm 503,510 item 2. FHL, Salt Lake City, Utah.

- Parish Chest Records, 1671-1920. Shropshire County Record Office, Shrewsbury. FHL microfilms 1,702,879 items 24-32; 1,702,903 items 1-8; 1,911,438 items 2-3. FHL, Salt Lake City, Utah.

- Churchwardens' and Overseers' Accounts, 1735-1936, Including Some Vestry Minutes. Shropshire County Record Office, Shrewsbury. FHL microfilms 1,701,619 items 6-7; 1,701,620 items 1-3. FHL, Salt Lake City, Utah.

- Contracts and Agreements, 1741-1819. P201/L/1. Shropshire Archives, Shrewsbury.

—. Settlement Examinations, 1717-1808. P201/L/3. Shropshire Archives, Shrewsbury.

—. Settlement Certificates, 1702-1757. P201/L/4. Shropshire Archives, Shrewsbury.

—. Removal Orders, 1683-1792. P201/L/5. Shropshire Archives, Shrewsbury.

—. Bastardy Bonds, 1710-1778. P201/L/6. Shropshire Archives, Shrewsbury. . Apprenticeship Indentures, 1672-1891. P201/L/8. Shropshire Archives, Shrewsbury. 
Apprenticeship Bonds, 1672-1752. P201/L/9. Shropshire Archives, Shrewsbury.

Maintenance Bonds, 1671-1771. P201/L/11. Shropshire Archives, Shrewsbury.

. Vestry Minutes, Poor Allowances, 1745-1746, 1747-1756, 1757-1764, 1764-1779, 1793-1800. P201, Fiches 175-179. Shropshire Archives, Shrewsbury.

- Ground Plan of Myddle Church, Showing Pews and How They Were Allotted, 8 July 1858. P201/Fiche 201. Shropshire Archives, Shrewsbury.

Prerogative Court of Canterbury Wills, 1384-1858. Will of William Gough, Gentleman of Sweeney, Shropshire. 4 May 1669. PROB 11/329/509. The National Archives, Kew, Richmond, Surrey.

\section{Published Materials}

"An Act for the Setting of the Poor on Work, and for the Avoiding of Idleness (18 Elizabeth c. 3)." In The Justice of the Peace and Parish Officer. Vol. 4. Edited by Richard Burn, Joseph Chitty, and Thomas Chitty. London, 1831.

"Beggars Act of 1531." In Tudor Constitutional Documents, A.D. 1485-1603. Edited by J. R. Tanner. New York: Cambridge University Press, 1922.

"The Beggars Song, Both in City and Country ..." 1686-1688. Magdalene College, Pepys Library. Pepys Ballads 4.250. English Broadside Ballad Archive (EBBA). University of California Santa Barbara. EBBA ID: 21910. Accessed 11 December 2017. https://ebba. english.ucsb.edu/ballad/21910/xml

"The Blind Eats Many a Flye: Or, the Broken Damsel made Whole." 1672-1696[?]. EBBA. University of California Santa Barbara. EBBA ID: 33545. Accessed 16 February 2016. http://ebba. english.ucsb.edu/ballad/33545/image.

Burn, Richard. The History of the Poor Laws with Observations. London: H. Woodfall and W. Strahan, 1764. Reprint, Clifton, New Jersey: Augustus Kelley Publishers, 1973.

Camden, William. Britannia. Vol. 1. Translated by Philemon Holland. London: 1610.

"Charles II, 1662: An Act for the better Releife of the Poore of this Kingdom." In Statutes of the Realm: Volume 5, 1628-80. Edited by John Raithby. Great Britain Record Commission, 1819. British History Online. Accessed 16 August 2016. http://www.british-history.ac. uk/statutes-realm/vol5/pp401-405.

Chaucer, Geoffrey. The Canterbury Tales: In Modern Verse. Edited by Joseph Glaser. Indianapolis: Hackett Publishing Company, Inc., 2005. 
Child, Josiah. A Method Concerning the Relief and Employment of the Poor Humbly Offer'd to the Consideration of the King and Both Houses of Parliament. London, 1699. EEBO. Accessed 17 February 2014. http://gateway.proquest.com/openurl?ctx_ver=Z39.882003\&res_id=xri:eebo\&rft_id=xri:eebo:citation: 12952483

Clare, John. Major Works. Edited and with an introduction and notes by Eric Robinson and David Powell and an introduction by Tom Paulin. New York: Oxford University Press, 2008.

Defoe, Daniel. "Letter VII: A Description of Part of Cheshire, Northamptonshire, and Leicestershire." In A Tour through the Whole Island of Great Britain: Divided into Circuits or Journeys. Vol. 2 (London: 1748).

Dugdale, William. The Antiquities of Warwickshire Illustrated: From Records, Leiger-Books, Manuscripts, Charters, Evidences, Tombes, and Armes, Beatified with Maps, Prospects, and Portraictures. London, 1656.

An Ease for Overseers of the Poore Abstracted from the Statutes. Cambridge, 1601. Early English Books Online (EEBO). Accessed 3 March 2014. http://gateway.proquest.com/ openurl?ctx_ver=Z39.88-2003\&res_id=xri:eebo\&rft_id=xri:eebo:citation:99849139.

Eden, Frederic Morton. The State of the Poor: A History of the Labouring Classes in England with Parochial Reports. Edited by A. G. L. Rogers. New York: E. P. Dutton \& Company, 1929.

Gough, Richard. The History of Myddle. With an introduction by W. G. Hoskins. Fontwell, Sussex: Centaur Press, 1968.

Gough, Richard. The History of Myddle. Edited and with an introduction and notes by David G. Hey. New York: Dorset Press, 1986.

Great Britain, Parliament, House of Commons. Reports from Committees of the House of Commons. Vol. 9, Provisions Poor, 1774-1802. N.p., 1803.

Great Britain, Parliament, House of Commons. Abstract of the Answers and Returns Made Pursuant to an Act, Passed in the 43d Year of His Majesty King George III, Intituled 'An Act for Procuring Returns Relative to the Expence and Maintenance of the Poor in England.' [London], 1804.

Hale, Matthew. A Discourse Touching Provision for the Poor. London, 1683. EEBO. Accessed 17 February 2014. http://gateway.proquest.com/openurl?ctx_ver=Z39.88-2003\&res_id $=$ xri:eebo\&rft_id=xri:eebo:citation: 12152263 . 
Hobbes, Thomas. Leviathan: Parts I and II. Rev. ed. Edited by A.P. Martinich and Brian Battiste. London, 1651. Reprint, Buffalo, New York: Broadview Editions, 2011.

Kennett, White. Parochial Antiquities Attempted in the History of Ambrosden, Burcester, and Other Adjacent Parts in the Counties of Oxford and Bucks. 2 vols. Oxford: 1818.

Kenyon, Robert Lloyd. Orders of the Shropshire Quarter Sessions. Vol. 1, 1638-1708. Shrewsbury: Shropshire County Council, 1902.

"A Lamentable Ballad of the Lady's Fall." 1720[?]. British Library. Roxburghe 3.570-571. EBBA. University of California Santa Barbara. EBBA ID: 31270. Accessed 16 February 2016. http://ebba.english.ucsb.edu/ ballad/31270/image.

Lanfiere, Thomas. "A Looking-Glass for a Bad Husband: Or, a Caveat for a Spend-thrift . . ." London, 1678-1688[?]. Houghton Library. Huth EBB65H 1.149. EBBA. University of California Santa Barbara. EBBA ID: 35241. Accessed 11 December 2017. https://ebba. english.ucsb.edu/ballad/35241/xml.

Langland, William. Piers Plowman: The Prologue and Passus I-VII of the B-Text. Edited by Terence Tiller. Ware, Hertfordshire: Wordsworth Editions Limited, 1999.

"A Looking-Glass for Lascivious Young Men: Or, the Prodigal Son Sifted Wherein Is Plainly Discovered the Follies and Extravagancies of a Young Man .. ." [London], 1689-1692. Magdalene College, Pepys Library. Pepys Ballads 2.7. EBBA. University of California Santa Barbara. EBBA ID: 20696. Accessed 16 February 2016. http://ebba.english.ucsb. edu/ballad/20696/image.

Malthus, Thomas Robert. An Essay on the Principle of Population. London, 1798.

Markham, Gervase. Country Contentments, or The English Huswife: Containing the Inward and Outward Vertues Which Ought to be in a Compleate Woman. London, 1623. EEBO. Accessed 3 March 2014. http://gate way.proquest.com/openurl?ctx_ver=Z39.88-2003 \&res_id=xri:eebo\&rft_id=xri:eebo:citation:99847308.

Marshall, William. Draft of a Poor Law. London, 1536.

More, Thomas. Utopia. Translated by Paul Turner. New York: Penguin Books, 2003.

North, Roger. A Discourse of the Poor, Shewing the Pernicious Tendency of the Laws now in Force for Their Maintenance and Settlement. London, 1753.

Perkins, William. A Warning against the Idolatrie of the Last Times and an Instruction Teaching Religious or Divine Worship. Cambridge, 1601. EEBO. Accessed 4 February 2015. http: //gateway.proquest. com/openurl?ctx_ver=Z39.88-2003\&res_id=xri:eebo\&rft_id=xri: eebo:citation:99898718. 
Phillimore, W. P. W., ed. Registers of Myddle. Shropshire Parish Registers. Lichfield Diocese. Vol. 19. [Shropshire]: Shropshire Parish Register Society, 1931.

Shropshire Archaeological and Parish Register Society. The Shropshire Hearth Tax Roll of 1672: Being a List of the Householders in the County. Shrewsbury, Shropshire: n.p., 1949. FHL microfilm 453,027, item 1. FHL, Salt Lake City, Utah.

Sokoll, Thomas, ed. Essex Pauper Letters, 1731-1837. New York: Oxford University Press, 2001.

Starkey, Thomas. A Dialogue between Reginald Pole and Thomas Lupset. London: Chatto and Windus, 1948.

\section{Secondary Sources}

Myddle and Shropshire

Cooper, Kathryn J. Exodus from Cardiganshire: Rural-Urban Migration in Victorian Britain. Cardiff: University of Wales Press, 2011.

Cross, Sylvia. "Richard Gough: A Shropshire Historian." Shropshire Unfolded (April 2004): 2325.

Cox, D. C., et al. A History of the County of Shropshire. Vol. 4, Agriculture. Edited by G. C. Baugh and C. R. Elrington. London: Victoria County History, 1989. British History Online. Accessed March 22, 2018, http://www.british-history.ac.uk/vch/salop/vol4.

Goodman, P. H. "Eighteenth-Century Poor Law Administration in the Parish of Oswestry." Transactions of the Shropshire Archaeological Society 56 (1960): 328-42.

Gough, F. H. and A. V. Gough. "The Goughs of Myddle and Their Descendants." In Transactions of the Shropshire Archaeological and Natural History Society. 2nd ser., vol. 5, part II. Oswestry: Woodall, Minshall, and Co., 1893.

Hey, David G. An English Rural Community: Myddle under the Tudors and Stuarts. Leicester: Leicester University Press, 1974.

Mayer, Robert. "'The History of Myddle': Memory, History, and Power." Studies in Philology 93, no. 1 (Winter 1996): 64-92.

McInnes, Angus. "The Emergence of a Leisure Town: Shrewsbury, 1660-1760." Past \& Present 120 (August 1988): 53-87. 
Rogers, E. M. W. A Short History of the Church and Parish of St. Peter's, Myddle, Shropshire. Myddle, Shropshire: Church of St. Peter's, 1984.

Walsh, Vincent J. "The Old and New Poor Laws in Shropshire, 1820-1870." Midland History 2, no. 4 (1974): 225-43.

\section{Community and Belonging}

Coy, Jason Philip. "Beggars at the Gates: Banishment and Exclusion in Sixteenth-Century Ulm." The Sixteenth Century Journal 39, no. 3 (Fall 2008): 619-38.

Dyer, Christopher, ed. The Self-Contained Village?: The Social History of Rural Communities, 1250-1900. Hatfield: University of Hertfordshire Press, 2007.

MacFarlane, Alan. Reconstructing Historical Communities. In collaboration with Sarah Harrison and Charles Jardine. New York: Cambridge University Press, 1977.

Schofield, Philipp R. "The Social Economy of the Medieval Village in the Early Fourteenth Century." Economic History Review 61, no. 1 (2008): 38-63.

Snell, K. D. M. "The Culture of Local Xenophobia." Social History 28, no. 1 (January 2003): 130.

- Parish and Belonging: Community, Identity and Welfare in England and Wales, 1700-1950. New York: Cambridge University Press, 2006.

Strathern, Marilyn. "The Village as an Idea: Constructs of Village-ness in Elmdon, Essex." In Belonging: Identity and Social Organisation in British Rural Cultures. Edited by Anthony Cohen. Manchester: Manchester University Press, 1982.

Tittler, Robert. "Seats of Honor, Seats of Power: The Symbolism of Public Seating in the English Urban Community, c. 1560-1620." Albion 24, no. 2 (Summer 1992): 205-23.

Gender

Bederman, Gail. "Sex, Scandal, Satire, and Population in 1798: Revisiting Malthus's First 'Essay.'" Journal of British Studies 47, no. 4 (October 2008): 768-95.

Crawford, Patricia and Laura Gowing, eds. Women's Worlds in Seventeenth-Century England: A Sourcebook. New York: Routledge, 2000. 
Farmer, Sharon. Surviving Poverty in Medieval Paris: Gender, Ideology, and the Daily Lives of the Poor. Ithaca: Cornell University Press, 2002.

Flather, Amanda. Gender and Space in Early Modern England. Rochester, New York: The Boydell Press, 2007.

French, Katherine. The People of the Parish: Community Life in a Late Medieval English Diocese. Philadelphia: University of Pennsylvania Press, 2001.

. The Good Women of the Parish: Gender and Religion after the Black Death. Philadelphia: University of Pennsylvania Press, 2008.

Frost, Ginger S. Living in Sin: Cohabiting as Husband and Wife in Nineteenth-Century England. New York: Manchester University Press, 2008.

Gowing, Laura. Domestic Dangers: Women, Words, and Sex in Early Modern London. New York: Oxford University Press, 1998.

Hull, Isabel V. Sexuality, State, and Civil Society in Germany, 1700-1815. Ithaca, New York: Cornell University Press, 1996.

Karras, Ruth Mazo. Unmarriages: Women, Men, and Sexual Unions in the Middle Ages. Philadelphia: University of Pennsylvania Press, 2012.

Scott, Joan Wallach. "Gender: A Useful Category of Historical Analysis." The American Historical Review 91, no. 5 (December 1985): 1053-75.

—. "Women in The Making of the English Working Class." In Gender and the Politics of History, ed. Joan Wallach Scott. New York: Columbia University Press, 1988.

Shepard, Alexandra. "Brokering Fatherhood: Illegitimacy and Paternal Rights and Responsibilities in Early Modern England." In Remaking English Society: Social Relations and Social Change in Early Modern England. Edited by Steve Hindle, Alexandra Shephard, and John Walter. Rochester, New York: The Boydell Press, 2013.

Stretton, Tim and Krista Kesselring, eds. Married Women and the Law: Coverture in England and the Common Law World. Montreal and Kingston: McGill-Queen's University Press, 2013.

Williams, Samantha. Poverty, Gender and Life-Cycle under the English Poor Law, 1760-1834. Rochester, New York: The Boydell Press, 2011. 
Historiography and Methodology

Bernau, Charles A. "The Genealogy of the Submerged." In Some Special Studies in Genealogy. London: Dunn Collin \& Co., Printers, 1908.

Fideler, Paul A. "Introduction: Impressions of a Century of Historiography." Albion: A Quarterly Journal Concerned with British Studies 32, no. 3 (Autumn 2000): 381-407.

Geertz, Clifford. "Thick Description: Toward an Interpretive Theory of Culture." In Interpretation of Culture. New York: Basic Books, 1973.

Ginzburg, Carlo. The Cheese and the Worms: The Cosmos of a Sixteenth-Century Miller. Translated by John Tedeschi and Anne Tedeschi. Baltimore: Johns Hopkins University Press, 1980.

—."Microhistory: Two or Three Things That I Know about It." Translated by John Tedeschi and Anne C. Tedeschi, Critical Inquiry 20, no. 1 (Autumn, 1993): 10-35.

Grendi, Edoardo. "Micro-analisi e storia sociale." Quaderni Storici 35 (1977): 506-20.

Hall, Catherine. "The State of Modern British History." History Workshop Journal 72 (Autumn 2011): 205-11.

Hoskins, W. G. Local History in England. London: Longmans, Green and Co. Ltd., 1965.

Jones, Gareth Stedman. "History and Theory: An English Story." Historein: A Review of the Past and Other Stories 3, no. 1 (2001): 103-24.

Kuehn, Thomas. "Reading Microhistory: The Example of Giovanni and Lusanna." The Journal of Modern History 61, no. 3 (September 1989): 512-34.

Laslett, Peter. The World We Have Lost: Further Explored. New York: Charles Scribner's Sons, 1984.

Levi, Giovanni. Inheriting Power: The Story of an Exorcist. Translated by Lydia G. Cochrane. Chicago: University of Chicago Press, 1988.

Mathieu, John. History of the Alps, 1500-1900: Environment, Development, and Society. Translated by Matthew Vester. Morgantown, West Virginia: West Virginia University Press, 2009.

Tristano, Richard M. "Microhistory and Holy Family Parish: Some Methodological Considerations." U.S. Catholic Historian 14, No. 3 (Summer 1996): 23-30. 
Illegitimacy

Adair, Richard. Courtship, Illegitimacy, and Marriage in Early Modern England. New York: Manchester University Press, 1996.

Helmholz, R. H. "Harboring Sexual Offenders: Ecclesiastical Courts and Controlling Misbehavior." Journal of British Studies 37, no. 3 (July 1998): 258-68.

Ingram, Martin. Church Courts, Sex and Marriage in England, 1570-1640. New York: Cambridge University Press, 1994.

King, Walter J. "Punishment for Bastardy in Early Seventeenth-Century England." Albion: A Quarterly Journal Concerned with British Studies 10, no. 2 (Summer 1978): 130-51.

Laslett, Peter and Karla Oosterveen. "Long-Term Trends in Bastardy in England: A Study of the Illegitimacy Figures in the Parish Registers and in the Reports of the Registrar General, 1561-1960." Population Studies 27, no. 2 (July 1973): 255-86.

Laslett, Peter, Karla Oosterveen, and Richard M. Smith, eds. Bastardy and Its Comparative History. Cambridge: Harvard University Press, 1980.

Meteyard, Belinda. "Illegitimacy and Marriage in Eighteenth-Century England" Journal of Interdisciplinary History 10, no. 3 (Winter 1980): 479-89.

Nutt, Thomas. "The Paradox and Problems of Illegitimate Paternity in Old Poor Law Essex." In Illegitimacy in Britain, 1700-1920. Edited by Alysa Levene, Thomas Nutt, and Samantha Williams. New York: Palgrave Macmillan, 2005.

Zlotnick, Susan. "'The Law's a Bachelor': 'Oliver Twist,' Bastardy, and the New Poor Law." Victorian Literature and Culture 34, no. 1 (2006): 131-46.

Labor and the Economy

Cavallo, Sandra. Artisans of the Body in Early Modern Italy: Identities, Families and Masculinities. New York: Manchester University Press, 2010.

Crawford, Patricia. Parents of Poor Children in England, 1580-1800. New York: Oxford University Press, 2010.

Cunningham, Hugh. "The Employment and Unemployment of Children in England, c. 16801851." Past \& Present 126 (February 1990): 115-50.

Curtler, W. H. R. A Short History of English Agriculture. New York: Clarendon Press, 1909.

Darnton, Robert. The Great Cat Massacre and Other Episodes in French Cultural History. New 
York: Vintage Books, 1985.

Davies, Margaret Gay. The Enforcement of English Apprenticeship: A Study in Applied Mercantilism, 1563-1642. Cambridge: Harvard University Press, 1956.

Fontaine, Laurence. The Moral Economy: Poverty, Credit, and Trust in Early Modern Europe. New York: Cambridge University Press, 2014.

Fowler, Christina. "Robert Mansbridge: A Rural Tailor and His Customers, 1811-1815." Textile History 28, no. 1 (1997): 29-38.

Hindle, Steve. "'Waste' Children?: Pauper Apprenticeship Under the Elizabethan Poor Laws, c. 1598-1697." In Women, Work and Wages in England, 1600-1850. Edited by Penelope Lane, Neil Raven, and K. D. M. Snell. Rochester, New York: The Boydell Press, 2004.

Honeyman, Katrina. Child Workers in England, 1780-1820: Parish Apprentices and the Making of the Early Industrial Labour Force. Burlington, Vermont: Ashgate Publishing Company, 2007.

Howell, Martha C. Commerce before Capitalism in Europe, 1300-1600. New York: Cambridge University Press, 2010.

Jensen, Hans E. "The Development of T. R. Malthus's Institutionalist Approach to the Cure of Poverty: From Punishment of the Poor to Investment in Their Human Capital." Review of Social Economy 57, no. 4 (December 1999): 450-65.

Lane, Joan. Apprenticeship in England, 1600-1914. London: University College London Press, 1996.

Levene, Alysa. "'Honesty, Sobriety and Diligence': Master-Apprentice Relations in Eighteenthand Nineteenth-Century England" Social History 33, no. 2 (2008): 183-200.

. "Parish Apprenticeship and the Old Poor Law in London." The Economic History Review 63, no. 4 (2010): 915-41.

Orme, Nicholas. Medieval Children. New Haven: Yale University Press, 2001.

Pinchbeck, Ivy and Margaret Hewitt. Children in English Society. Vol. 1, From Tudor Times to the Eighteenth Century. Toronto: University of Toronto Press, 1969.

Rutherford, Donald. "Malthus and Three Approaches to Solving the Population Problem." Population 62, No. 2 (2007): 213-37. 
Simonton, Deborah. "Apprenticeship: Training and Gender in Early Eighteenth-Century England." In Markets and Manufacture in Early Industrial Europe. Edited by Maxine Berg. New York: Routledge, Chapman and Hall, 1991.

Smith, Steven R. "The London Apprentices as Seventeenth-Century Adolescents." Past \& Present 61 (November 1973): 149-61.

Stobart, Jon. "The Economic and Social Worlds of Rural Craftsmen-Retailers in EighteenthCentury Cheshire." The Agricultural History Review 52, no. 2 (2004): 141-60.

Thompson, E. P. The Making of the English Working Class. New York: Vintage Books, 1966.

Woodward, Donald. "The Background to the Statute of Artificers: The Genesis of Labour Policy, 1558-63." The Economic History Review, n.s., 33, no. 1 (February 1980): 32-44.

Politics, Culture, and Religion

Bossy, John. Christianity in the West, 1400-1700. New York: Oxford University Press, 1985.

Colley, Linda. Britons: Forging the Nation, 1707-1837. Rev. ed. New Haven: Yale University Press, 2009.

Constable, John. The Southwark Mysteries. London: Oberon Books, 2011.

Corfield, Penelope J. Language, History and Class. Cambridge, Massachusetts: Basil Blackwell, Inc., 1991.

Cressy, David. Birth, Marriage, and Death: Ritual, Religion, and the Life-Cycle in Tudor and Stuart England. New York: Oxford University Press, 1997.

Cross Bones Graveyard. Accessed 1 Nov 2017. crossbones.org.uk.

Duffy, Eamon. The Stripping of the Altars: Traditional Religion in England, c. 1400-c. 1580. New Haven, Connecticut: Yale University Press, 1992.

Elton, G. R. England under the Tudors, 3rd ed. New York: Routledge, 1991.

Gorji, Mina. "Clare's 'Merry England.'" The John Clare Society Journal 24 (July 2005): 5-24.

Grell, Ole Peter, Andrew Cunningham, and Robert Jütte, eds. Health Care and Poor Relief in 18th and 19th-Century Northern Europe. New York: Routledge, 2002. 
Hill, Christopher. The World Turned Upside-Down. [London]: Maurice Temple Smith, 1972. Reprint, New York: Penguin Putnam Inc., 1991.

Hutton, Ronald. The Rise and Fall of Merry England: The Ritual Year 1400-1700. New York: Oxford University Press, 1994.

. The Stations of the Sun: A History of the Ritual Year in Britain. New York: Oxford University Press, 2001.

Marsh, Christopher. "Order and Place in England, 1580-1640: The View from the Pew." Journal of British Studies 44, no. 1 (January 2005): 3-26.

Moore, R. I. The Formation of a Persecuting Society: Authority and Deviance in Western Europe, 950-1250, 2nd ed. Malden, Massachusetts: Blackwell Publishing, 2007.

Sussman, Marvin B. "Law and Legal Systems: The Family Connection." In Family and Support Systems across the Life Span. Edited by Suzanne K. Steinmetz. New York: Plenum Press, 1988.

Tate, W. E. The Parish Chest: A Study of the Records of Parochial Administration in England. 3rd ed. New York: Cambridge University Press, 1969.

Thompson, E. P. Customs in Common: Studies in Traditional Popular Culture. New York: The New Press, 1993.

Todd, Margo. Christian Humanism and the Puritan Social Order. New York: Cambridge University Press, 1987.

Waddell, Brodie. God, Duty and Community in English Economic Life, 1660-1720. Rochester, New York: The Boydell Press, 2012.

Walter, John. Crowds and Popular Politics in Early Modern England. New York: Manchester University Press, 2006.

Medieval Poverty and Poor Relief

Bailey, Mark. The Decline of Serfdom in Late Medieval England: From Bondage to Freedom. Woodbridge, Suffolk: The Boydell Press, 2014.

Bennett Judith M. "Conviviality and Charity in Medieval and Early Modern England." Past \& Present 134 (February 1992): 19-41. 
Crassons, Kate. The Claims of Poverty: Literature, Culture, and Ideology in Late Medieval England. Notre Dame: University of Notre Dame Press, 2010.

Davis, Adam J. "The Social and Religious Meanings of Charity in Medieval Europe." History Compass 12, no. 12 (December 2014): 935-50.

Edgren, Allison. "From Saint Francis to Salimbene di Adam: Begging in the Early Franciscan World, c. 1210-80." In Approaches to Poverty in Medieval Europe: Complexities, Contradictions, Transformations, c. 1100-1500. Edited by Sharon Farmer. Turnhout, Belgium: Brepols, 2016.

Freedman, Paul. Images of the Medieval Peasant. Stanford: Stanford University Press, 1999.

Geremek, Bronisław. The Margins of Society in Late Medieval Paris. Translated by Jean Birrell. New York: Cambridge University Press, 1987.

Little, Lester K. Religious Poverty and the Profit Economy in Medieval Europe. New York: Cornell University Press, 1978.

McIntosh, Marjorie Keniston. Poor Relief in England, 1350-1600. New York: Cambridge University Press, 2012.

Mollat, Michel. The Poor in the Middle Ages: An Essay in Social History. Translated by Arthur Goldhammer. New Haven, Connecticut: Yale University Press, 1986.

Muldrew, Craig. "'Hard Food for Midas': Cash and Its Social Value in Early Modern England." Past \& Present, no. 170 (February 2001): 78-120.

O'Halloran, Kelly, Myles McGregor-Lowndes, and Karla W. Simon. Charity, Law and Social Policy: National and International Perspectives on the Functions of the Law Relating to Charities. Dordrecht: Springer, 2008.

Rubin, Miri. Charity and Community in Medieval Cambridge. New York: Cambridge University Press, 1987.

Early Modern and Modern Poverty and Poor Relief

Allegra, Luciano. "Becoming Poor in Eighteenth-Century Turin." Journal of Interdisciplinary History, 46, no. 2 (Autumn 2015): 153-83.

Beier, A. L. Masterless Men: The Vagrancy Problem in England, 1560-1640. New York: Methuen \& Co. Ltd, 1985. 
Blaug, Mark. "The Myth of the Old Poor Law and the Making of the New." The Journal of Economic History 23, no. 2 (June 1963): 151-84.

Boulton, Jeremy. "'It is Extreme Necessity That Makes Me Do This': Some Survival Strategies of Pauper Households in London's West End during the Early Eighteenth Century," International Review of Social History 45 (Supplement) (2000): 47-69.

Boyer, George R. An Economic History of the English Poor Law. New York: Cambridge University Press, 1990.

Broad, John. "Parish Economies of Welfare, 1650-1834." The Historical Journal 42, no. 4 (December 1999): 985-1006.

Brundage, Anthony. The English Poor Laws, 1700-1930. New York: Palgrave, 2002.

Cowherd, Raymond G. "The Humanitarian Reform of the English Poor Laws from 1782 to 1815," The Proceedings of the American Philosophical Society, 104, no. 3 (June 1960): $328-42$.

Crossan, Rose-Marie. Poverty and Welfare in Guernsey, 1560-2015. Woodbridge, Suffolk: The Boydell Press, 2015.

Digby, Anne. Pauper Palaces. Boston: Routledge \& Kegan Paul, 1978.

Ely, Jr., James W. "The Eighteenth-Century Poor Laws in the West Riding of Yorkshire." The American Journal of Legal History 30, no. 1 (January 1986): 1-24.

Fideler, Paul A. Social Welfare in Pre-Industrial England: The Old Poor Law Tradition. New York: Palgrave, 2006.

Green, David R. Pauper Capital: London and the Poor Law, 1790-1870. New York: Routledge, 2016.

Gutton, Jean-Pierre. La Société et les pauvres: L'exemple de la généralité de Lyon,1534-1789. Paris: Les Belles Lettres, 1971.

Healey, Jonathan. "Poverty in an Industrializing Town: Deserving Hardship in Bolton, 1674-99." Social History 35, no. 2 (2010): 125-47.

Hindle, Steve. "The Problem of Pauper Marriage in Seventeenth-Century England." Transactions of the Royal Historical Society, 6th ser., 8 (1998): 71-89. 
—. "Dependency, Shame and Belonging: Badging the Deserving Poor, c. 1550-1750." Cultural and Social History 1, no. 1 (2004): 6-35.

On the Parish?: The Micro-Politics of Poor Relief in Rural England, c. 1550-1750. New York: Oxford University Press, 2004.

. "Beating the Bounds of the Parish: Order, Memory, and Identity in the English Local Community, c. 1500-1700." In Defining Community in Early Modern Europe. Edited by Michael J. Halvorson and Karen E. Spierling. Burlington, Vermont: Ashgate Publishing, 2008.

Hitchcock, David. "A Typology of Travellers: Migration, Justice, and Vagrancy in Warwickshire, 1670-1730." Rural History 23, no. 1 (2012): 21-39.

Hitchcock, Tim and Robert Shoemaker. London Lives: Poverty, Crime and the Making of the Modern City, 1690-1800. New York: Cambridge University Press, 2015.

Hufton, Olwen. The Poor of Eighteenth-Century France, 1750-1789. Oxford: Clarendon Press, 1974.

Innes, Joanna. "The 'Mixed Economy of Welfare' in Early Modern England: Assessments of the Options from Hale to Malthus (c. 1683-1803)." In Charity Self-Interest and Welfare in the English Past. Edited by M. J. Daunton. New York: St. Martin's Press, 1996.

Jones, Peter D. "'I Cannot Keep My Place without Being Deascent': Pauper Letters, Parish Clothing and Pragmatism in the South of England, 1750-1830." Rural History 20, no. 1 (2009): 31-49.

Jordan, W. K. Philanthropy in England, 1480-1660: A Study of the Changing Pattern of English Social Aspirations. New York: Russell Sage Foundation, 1959.

Jütte, Robert. Poverty and Deviance in Early Modern Europe. New York: Cambridge University Press, 1994.

King, Steve. "Reconstructing Lives: The Poor, the Poor Law, and Welfare in Calverley, 1650-1820." Social History 22, no. 3 (October 1997): 318-38.

King, Steven. Poverty and Welfare in England, 1700-1850: A Regional Perspective. Manchester: Manchester University Press, 2000.

Lees, Lynn Hollen. The Solidarities of Strangers: The English Poor Laws and the People, 1700- 
1948. New York: Cambridge University Press, 1998.

Lindemann, Mary. Patriots and Paupers: Hamburg, 1712-1830. New York: Oxford University Press, 1990.

Marshall, Dorothy. The English Poor in the Eighteenth Century: A Study in Social and Administrative History, 1662-1782. 1926. Reprint, Abingdon, Oxfordshire: Routledge, 2007.

Marshall, J. D. The Old Poor Law, 1795-1834. New York: The MacMillan Press Ltd, 1968.

Nicholls, George. A History of the English Poor Law in Connection with the State of the Country and the Condition of the People. Vol. 1, A.D. 924 to 1714. Rev. ed. 1854. Reprint, New York: Augustus M. Kelley Publishers, 1967.

Ottaway, Susannah. The Decline of Life: Old Age in Eighteenth-Century England. New York: Cambridge University Press, 2004.

_. "Women, Household and Independence under the Old English Poor Laws." In Female Economic Strategies in the Modern World. Edited by Beatrice Moring. New York: Routledge, 2016.

Poynter, J. R. Society and Pauperism: English Ideas on Poor Relief, 1795-1834. Toronto: University of Toronto Press, 1969.

Schen, Claire S. "Constructing the Poor in Early Seventeenth-Century London." Albion 32, no. 3 (Autumn 2000): 450-63.

Sherman, Sandra. Imagining Poverty: Quantification and the Decline of Paternalism. Columbus: Ohio State University Press, 2001.

Slack, Paul. The English Poor Law, 1531-1782. New York: Cambridge University Press, 1990.

Snell, K. D. M. Annals of the Labouring Poor: Social Change and Agrarian England, 16601900. New York: Cambridge University Press, 1985.

- $\quad$ "Settlement, Poor Law and the Rural Historian: New Approaches and Opportunities." Rural History 3, vol. 2 (1992): 145-72.

Song, Byung Khun. "Parish Typology and the Operation of the Poor Laws in Early NineteenthCentury Oxfordshire." The Agricultural History Review, 50, no. 2 (2002): 203-24. 
Taylor, J. S. "The Unreformed Workhouse, 1776-1834." In Comparative Development in Social Welfare. Edited by E. W. Martin. London: Allen and Unwin, 1972.

Tomkins, Alannah and Steven King, eds. The Poor in England, 1700-1850: An Economy of Makeshifts. Manchester: Manchester University Press, 2003.

Tomkins, Alannah. The Experience of Poverty, 1723-82: Parish, Charity and Credit. Manchester: Manchester University Press, 2006.

Wales, Tim. "Poverty, Poor Relief and the Life-Cycle: Some Evidence from SeventeenthCentury Norfolk." In Land, Kinship, and Life-Cycle. Edited by Richard M. Smith. New York: Cambridge University Press, 1984.

Webb, Sidney and Beatrice Webb. The Parish and the County. Vol. 1, English Local Government. London: Longmans, Green and Company, 1906.

. English Poor Law History, Part I: The Old Poor Law. Vol. 7, English Local Government. London: Longmans, Green and Company, 1927.

- English Poor Law History, Part II: The Last Hundred Years. 2 vols. Vols. 8 and 9, English Local Government. London: Longmans, Green and Company, 1929.

Woodbridge, Linda. Vagrancy, Homelessness, and English Renaissance Literature. Urbana: University of Illinois Press, 2001. 